\title{
ORGANIZAÇÃO E PEDOGÊNESE DE UM SISTEMA LATOSSOLO-PODZOL NA REGIÃO DO ALTO RIO NEGRO, AMAZONAS
}

\author{
ÁLVARO LUIZ MAFRA
}

Engenheiro Agrônomo

Orientador: Prof. Dr. ANDREAS ATTILA DE WOLINSK MIKLÓS

Tese apresentada à Escola Superior de Agricultura "Luiz de Queiroz", Universidade de São Paulo, para obtenção do título de Doutor em Agronomia, Área de Concentração: Solos e Nutrição de Plantas.

P I R A C I C A B A

Estado de São Paulo - Brasil

Março - 2000 


\title{
Dados Internacionais de Catalogação na Publicaçāo (CIP) DIVISĀO DE BIBLIOTECA E DOCUMENTAÇĀO - Campus "Luiz de Oueiroz"/USP
}

\author{
Mafra, Álvaro Luiz. \\ Organização e pedogênese de um sistema latossolo-podzol na região do alto Rio Negro, \\ Amazonas / Álvaro Luiz Mafra. - - Piracicaba, 2000. \\ 161 p. : il. \\ Tese (doutorado) - Escola Superior de Agricultura Luiz de Queiroz, 2000. \\ Bibliografia. \\ 1. Granito 2. Latossolo 3. Mineralogia do solo 4. Morfogênese 5. Podzólico 6. Solo \\ hidromórfico 7. Solo tropical I. Titulo
}

CDD 631.44 


\section{AGRADECIMENTOS}

- Ao Prof. Dr. Andreas Attila de Wolinsk Miklós, pela orientação, ensinamentos e amizade;

- Ao Prof. Dr Adolpho José Melfi, pelo oportunidade de participação e apoio financeiro no projeto de pesquisa sobre as coberturas ferralíticas da Amazônia (Ministério da Ciência e Tecnologia, PRONEX, 97 e Fundação de Amparo à Pesquisa do Estado de São Paulo, FAPESP);

- Ao Departamento de Solos e Nutrição de Plantas, pela oportunidade de realização do doutoramento;

- Ao Conselho Nacional de Desenvolvimento Científico e Tecnológico (CNPq), pela bolsa de estudos concedida;

- Ao pesquisador Dr. Boris Volkoff, do "Institut de Recherche pour le Developpment" (IRD, ex-ORSTOM), que nos acompanhou em duas viagens ao campo e pelas correções e sugestões apresentadas no manuscrito. Agradeço também aos pesquisadores: Dr. Rene Boulet e Prof. Dr. Adilson Carvalho (Instituto de Geociências, IG/USP) e Dr. Vincent Eschenbrenner (IRD, ex-ORSTOM), que acompanharam as missões de campo;

- Ao Dr. Fernando Pereira de Carvalho, Superintendente Regional da Companhia de Pesquisa de Recursos Minerais (CPRM/Manaus, AM), pelo fornecimento de mapas da região e por ter cedido um funcionário (Sr. Márcio), que nos auxiliou no reconhecimento dos solos na região do alto Rio Negro;

- À Prof. Dr. Célia Regina Montes-Lauar, pela acolhida no Núcleo de Pesquisa em Geoquímica e Geofisica da Litosfera (NUPEGEL/ESALQ/USP);

- À funcionária Maria Elisabete H. B. Guimarães, pelas análises térmicas (ATD);

- À $\mathrm{Dr}^{\mathrm{a}}$. Maria Cristina Forti (INPE), pelas análises químicas das águas;

- À $\operatorname{Dr}^{a}$. Ana G. Moreno (Universidad Complutense de Madrid), pelo auxilio na taxonomia das minhocas;

- Ao Engenheiro Ney Pinheiro Sampaio, pelo auxílio nas análises de difração de raio-X e microscopia eletrônica de varredura e pela amizade; 
- Ao colega Enio Fraga da Silva do Centro Nacional de Pesquisa de Solos (EMBRAPACNPS), pelo auxilio na classificação dos solos e pela amizade;

- Aos funcionários: Clotilde Batóchio, Felipe Grizotto e Paulo Sebastião; aos pósgraduandos: Celso Graminha e Márcia Soares (NUPEGEL/USP); e, em conjunto aos funcionários do Departamento de Solos e Nutrição de Plantas, pelo convívio;

- Aos familiares, pelo estímulo e compreensão. 


\section{SUMÁRIO}

Página

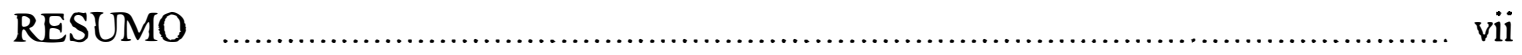

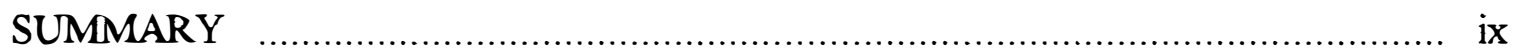

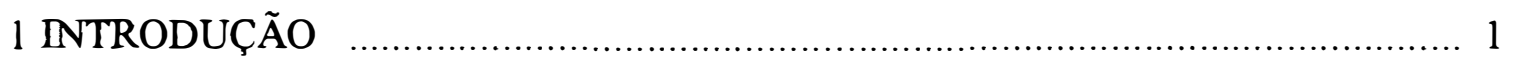

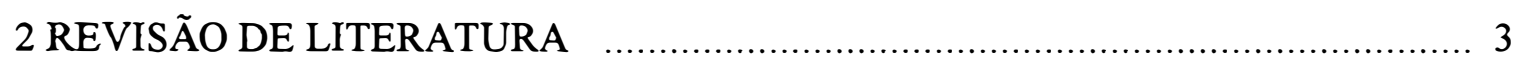

2.1 Evolução mineralógica em ambiente tropical úmido com drenagem livre ............ 4

2.2 Hidromorfismo e alteração dos minerais ...................................................... 5

2.3 Podzolização: processo geoquímico e pedológico …….................................... 7

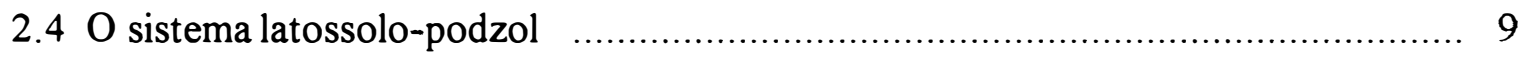

2.5 Caracterização do meio físico: a bacia do Rio Negro ……............................ 11

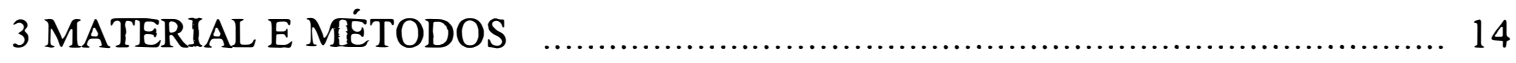

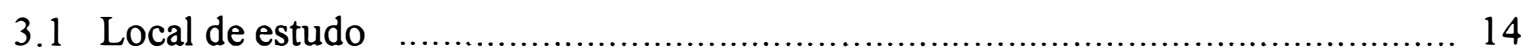

3.2 Caracterização da cobertura pedológica ….............................................. 16

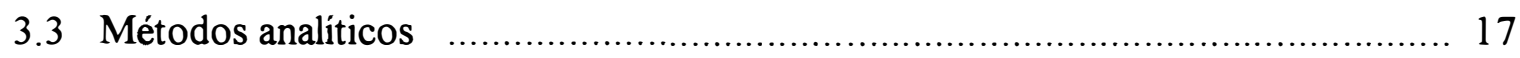

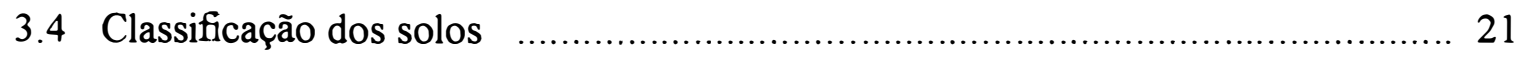

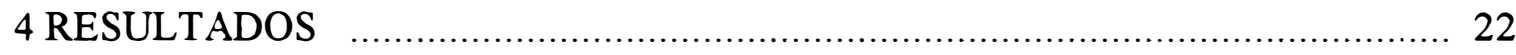

4.1 Aspecto superficial do terreno e morfologia das vertentes …........................ 22

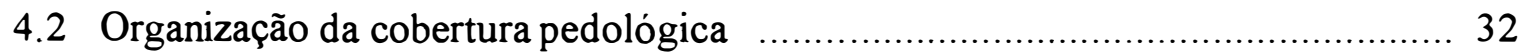

4.2.1 Atividade das minhocas nos solos da planície hidromórfica $\quad \ldots \ldots \ldots \ldots \ldots \ldots \ldots \ldots . . \ldots \ldots$

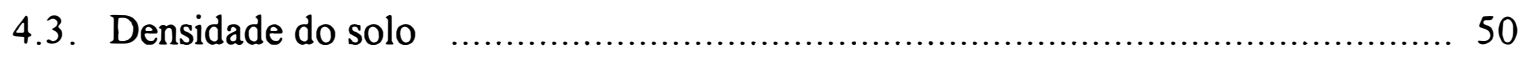

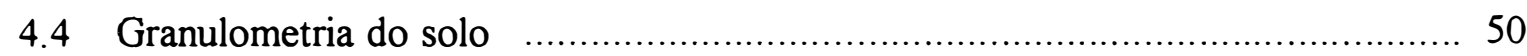

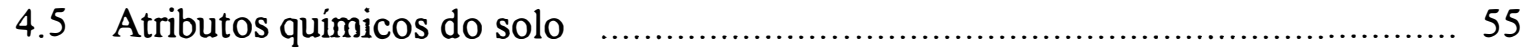

4.5.1 pH, elementos trocáveis, carbono orgânico e formas do ferro ……................ 55

4.5.2 Elementos extraídos pelo ataque sulfúrico ……....................................... 58

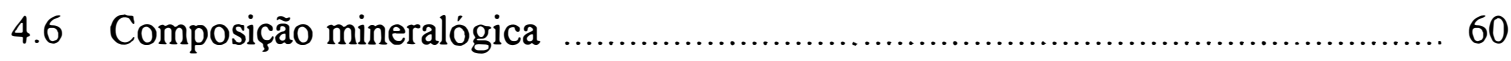

4.6.1 Mineralogia dos grãos de cascalho e areia fina .............................................6 60

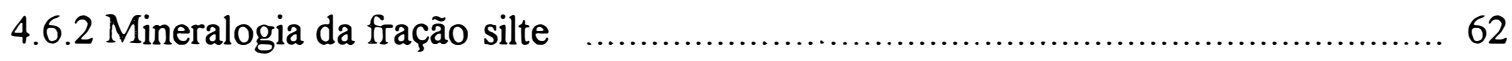




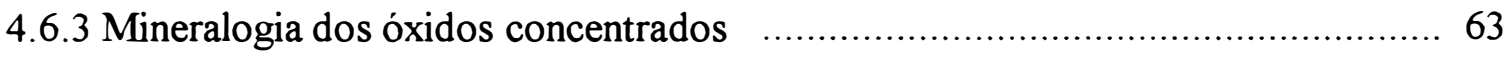

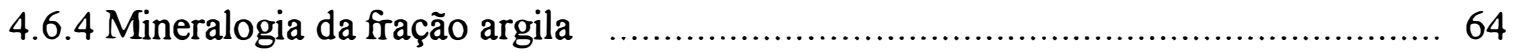

4.6.5 Alteração dos minerais primários e constituição do plasma ………………....... 67

4.7 Aspecto morfoscópico dos grãos de quartzo ………..................................6 68

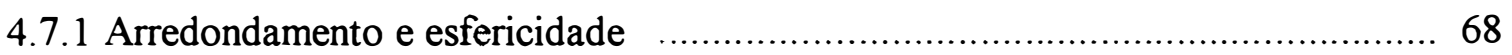

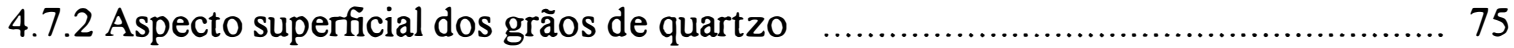

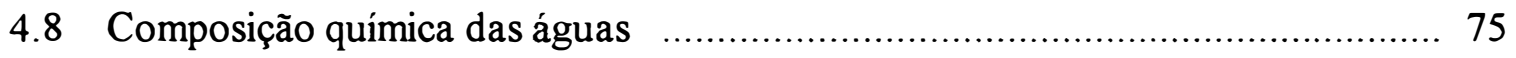

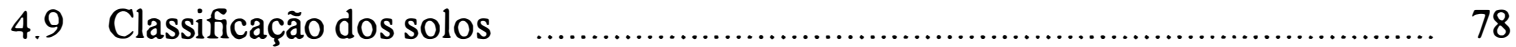

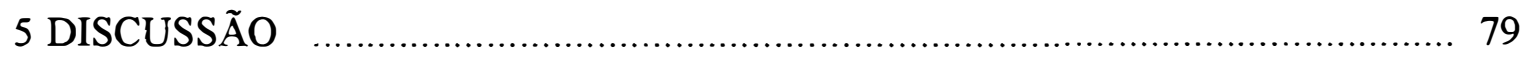

5.1 Pedogênese nos solos da colina f............................................................. 79

5.2 Relações entre os domínios latossólico e hidromórfico ….............................. 81

5.3 Transformação dos solos na colina e formação das areias brancas …….......... 85

5.4 Pedogênese nos solos da planície hidromórfica e evolução do manto arenoso ... 92

5.5 Podzolização e formação do horizonte $\mathrm{Bh}$................................................. 97

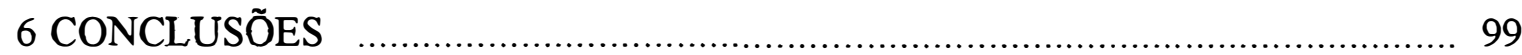

ANEXO A: Descrição macromorfológica dos perfis estudados ………............... 101

ANEXO B: Descrição meso e micromorfológica dos perfis estudados …............... 122

ANEXO C: Atributos fisicos do solo: densidade e granulometria ….................... 134

ANEXO D: Difratogramas de raio-X: frações silte, óxidos concentrados e argila .... 140

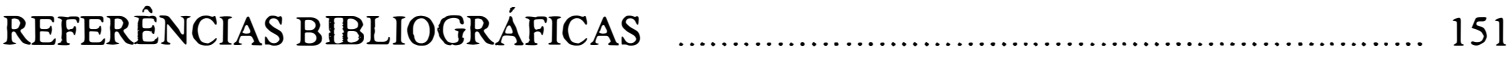




\title{
ORGANIZAÇÃO E PEDOGÊNESE DE UM SISTEMA LATOSSOLO-PODZOL NA REGIÃo DO ALTO RIO NEGRO, AMAZONAS
}

\author{
Autor: ÁLVARO LUIZ MAFRA \\ Orientador: PROF. DR. ANDREAS ATILLA DE WOLINSK MIKLÓS
}

\section{RESUMO}

A tese trata da formação de solos arenosos hidromórficos, encontrados em extensas planícies, onde ocorrem áreas isoladas de latossolos, em terrenos ondulados e drenados. O objetivo do estudo é elucidar a existência de um sistema latossolo-podzol, verificando a relação genética entre eles e o possível desenvolvimento dos solos arenosos por transformação dos latossolos. Para tanto, foram caracterizados a morfologia dos solos e seus atributos fisicos, químicos e mineralógicos. A composição química das águas foi determinada e relacionada com os processos pedogenéticos envolvidos. A seqüência de solos mostra evidências morfológicas e analiticas, que indicam desenvolvimento autóctone e filiação com o material de origem granitico. Os solos no domínio latossólico e hidromórfico mostram relações pedogenéticas que apontam para transformação do latossolo, ligada a condições de saturação hídrica crescente, iniciando pelo amarelecimento, seguido pela gleização na periferia da colina. Nesta zona observa-se gradual empobrecimento em argila em subsuperficie, que se estende lateralmente em direção ao plano, onde se encontra o material arenoso. Esta diferenciação se verifica numa escala métrica, associada ao processo pedogeoquímico de acidólise parcial, que provoca dissolução de grande quantidade de gibbsita e caulinita, liberando alumínio, o que é constatado por mudanças na composição das águas. O transporte mecânico na forma microparticular parece exercer papel secundário. Na planície hidromórfica observase acúmulo de quartzo compondo as areias brancas. Abaixo deste conjunto eluvial verifica-se, num lado da seqüência, uma alterita com gibbsita sob o horizonte $\mathrm{Bh}$ 
endurecido. Na maior parte da área, ocorre um conjunto claro areno-argiloso, com predomínio de caulinita na fração argila, disposto abaixo do horizonte Bh solto. A formação do horizonte $\mathrm{Bh}$ do podzol hidromórfico é um processo posterior a formação do material arenoso e se dá pela redistribuição de matéria orgânica, acompanhando o fluxo hídrico subsuperficial. No horizonte espódico observa-se um plasma orgânico preenchendo os espaços intergranulares e canais de raizes, depositado por ação mecânica de filtração numa camada mais adensada em contato com o saprolito ou conjunto claro mais argiloso. A precipitação de compostos orgânicos ligados a alumínio, presente nas soluções em subsuperficie, pode também estar envolvida na gênese do horizonte $\mathrm{Bh}$. $\mathrm{O}$ tipo de podzolização encontrada nessa seqüência difere da verificada em outras áreas da Amazônia, e se caracteriza fundamentalmente pela ação das águas ácidas do plano hidromórfico sobre o solo mais argiloso da colina. As areias brancas formam-se nestas condições abaixo do conjunto latossólico, que se desestabiliza e se degrada a medida que ocorre a remoção da fração fina, provocando o rebaixamento do terreno e contato com as águas do plano. A evolução lateral dos solos no sentido latossolo-podzol reforça a hipótese de formação das areias brancas por processos pedogeoquímicos e contribui para explicar o aplainamento geral do terreno observado nesta região. 


\title{
ORGANIZATION AND PEDOGENESIS OF AN OXISSOL-SPODOSSOL SOIL SYSTEM IN THE UPPER RIO NEGRO, AMAZONAS
}

\author{
Author: ÁLVARO LUIZ MAFRA \\ Adviser: PROF. DR. ANDREAS ATILLA DE WOLINSK MIKLÓS
}

\section{SUMMARY}

This thesis deals with the genesis of hidromorphic sandy soils found in extensive flat surfaces, in which isolated zones containing oxissols occur, in drained and undulating relief. The objective of this study was to explain the existence of an oxissolpodzol system, and to verify the genetic relationship between this soils, as well as the development of the sandy soils as a consequence of oxissol transformation. For this purpose, we characterized morphology of the soils and their physical, chemical and mineralogical attributes. Chemical composition of soil waters were determined and related to soil pedogenetic processes. These soil sequence showed morphological and analytical evidences that pointed to an autochthonous development and a filiation to granitic parental material. Soils in oxissol and hydromorphic domains revealed existence of a genetic relationship and suggested a transformation of the oxissol, caused by increasing waterlogged conditions. Increasing soil yellowing was followed by gleization near the edge zone of the hill. In this part of the soil sequence, we observed progressive clay depletion in the subsuperficial soil layer, that extended towards the plain surface, composed with sandy material. This soil differentiation occured in a metric scale and was induced by pedogeochemical process consisting of partial acidolysis, which caused ample gibbsite and kaolinite dissolution, and aluminium discharge, resulting in changes in the chemical composition of soil solutions. In this case, mechanical movement of the clays in microparticular form might have played a secondary role. In the flat hydromorphic zone, we found a quartz sandy layer composed of white sands. A gibbsitic saprolite beneath a 
hard Bh horizon was present below elluvial material in some parts of the sequence. Most of the flat areas had subsuperficial argillic horizons, composed mainly of kaolinite in clay size fraction, arranged below white sand layers and beneath soft $\mathrm{Bh}$ horizons. Development of the spodic horizon in waterlogged podzols was a later process than formation of the sandy soil and occured by organic matter redistribution, along with water flux in subsuperficial soil layers. Organic plasma placed in Bh horizon clogged intergranular spaces and root channels, and was deposited by filtering mechanisms in a more compact layer adjacent to saprolite or argillic material. Deposition of organic components combined to aluminium ion, that occured in subsuperficial waters could have taken place in the genesis of $\mathrm{Bh}$ horizon. This kind of podzolisation process found in the soil sequence was different from others seen in the Amazon basin, and was characterized by the action of acidic waters from the plain in contact with more clayed materials in the hill. White sands were formed in these conditions below the oxidic domain, which decayed and was degraded following clay depletion, causing soil depression and contact with acidic waters. Lateral evolution of the soil, with oxissol transformation was in accordance with white sand formation by pedogeochemical processes, and concured to explain the development of the wide flat surfaces seen in this region. 


\section{INTRODUÇÃO}

A Amazônia brasileira abrange cerca de $5.000 .000 \mathrm{~km}^{2}$, equivalente a $57 \%$ do pais, sendo caracterizada, em termos de solos, pelo predomínio de coberturas pedológicas em avançado estágio de intemperismo. Estes solos arranjam-se em diversos sistemas pedológicos, ordenadamente distribuidos na paisagem, com extrema diversidade de organizações e de estruturas que, em conjunto, são identificadas como coberturas ferralíticas. Este termo é derivado do processo geoquímico de ferralitização e relaciona-se com o tipo de alteração predominante em regiões tropicais úmidas e com drenagem livre, que ocasiona decomposição dos minerais primários e resulta na formação de argilominerais 1:1 e óxi-hidróxidos de ferro e alumínio. Do ponto de vista pedológico, os solos ferralíticos correspondem aos Oxissolos e Ultissolos da classificação americana; aos Ferralsolos da classificação da FAO e aos Latossolos e parte dos Podzólicos no Brasil.

A compreensão da formação e evolução dessas coberturas pedológicas é imprescindivel para a conservação e uso racional dos recursos naturais dessa região, face a inter-relação solo, biota e sistemas hídricos, todos em delicado equilibrio. A caracterização da organização e funcionamento desses solos tem motivado a participação de um grupo de pesquisa da Universidade de São Paulo. O trabalho faz parte de um projeto temático, intitulado "Organização e funcionamento hidrobiogeoquímico das coberturas lateríticas da Amazônia", coordenado pelo professor Dr. Adolpho José Melfi (ESALQ/USP). Os trabalhos integram estudos regionais e de seqüências de solos, com definição da distribuição espacial das coberturas pedológicas. Em áreas representativas da paisagem regional estão sendo determinadas a constituição mineralógica e estrutural, com o reconhecimento dos mecanismos e processos pedogeoquímicos elementares. 
A presente tese fez parte desse estudo mais abrangente e trata da formação de solos arenosos que se distribuem em extensas áreas aplainadas na região do alto Rio Negro (Amazonas). Muitos destes solos apresentam morfologia de podzol e estão relacionados a ambientes saturados em água. Nessa paisagem ocorrem algumas áreas isoladas de latossolos, presentes em terrenos ondulados e mais elevados em relação ao plano circundante.

O objetivo deste trabalho é elucidar a existência de um sistema latossolopodzol, verificando a relação genética entre eles e o possível desenvolvimento dos solos arenosos a partir da transformação dos latossolos. Os objetivos específicos compreendem:

- Identificar e descrever as organizações estruturais ao longo de uma seqüência latossolo-podzol, para revelar a relação entre esses dois domínios, indicando a possível existência de um sistema de transformação;

- Caracterizar os constituintes biológicos, fisicos, químicos e mineralógicos do solo e relacioná-los aos processos pedogenéticos;

- A partir dos resultados morfológicos e biofisicoquímicos preliminares, pretende-se caracterizar a dinâmica de íons em solução, relacionando as perdas de elementos com o funcionamento de um provável sistema de alteração. 


\section{REVISÃO DE LITERATURA}

O conhecimento científico dos solos da Amazônia brasileira é recente. Até o início da década de 50 as informações eram esparsas e provinham de descrições realizadas por naturalistas e geólogos. Durante a década de 70 foi efetuado o levantamento exploratório pelo projeto Radam (Radar na Amazônia), que abrangeu $4.600 .000 \mathrm{~km}^{2}$ e caracterizou, além dos solos (publicado na escala 1:1.000.000), a geologia, geomorfologia, climatologia, vegetação e uso potencial da terra (Falesi, 1986). Em 1981 a equipe do Serviço Nacional de Levantamento e Classificação de Solos publicou o Mapa de Solos do Brasil, na escala 1:5.000.000, identificando as principais associações geográficas de solos presentes (Empresa Brasileira de Pesquisa Agropecuária - EMBRAPA, 1981). Mais recentemente efetuou-se uma compilação de estudos pedológicos, envolvendo a distribuição dos solos nas paisagens da Amazônia brasileira, a partir dos quais elaborou-se um modelo conceitual de sua evolução hidrobiogeoquímica (Melfi et al., 1996). Constatou-se a predominância de coberturas ferraliticas, estendendo-se por $80 \%$ da bacia e, sua formação, foi interpretada como sendo fruto da evolução dos solos em condições de clima quente e úmido, sob ação de processos que vêm se desenvolvendo em meio drenado e oxigenado. Verificou-se também que uma importante porção da Bacia Amazônica, notadamente na porção noroeste (alto Rio Negro), apresenta uma diferenciação na cobertura pedológica, com a ocorrência de extensas áreas aplainadas, associadas a condições hidromórficas e recobertas por solos como Podzóis Hidromórficos e Areias Quartzosas Hidromórficas.

Esses domínios hidromórficos ocupam sistematicamente as posições baixas do modelado, com distribuição radial em relação ao eixo de drenagem e normalmente distribuem-se na periferia das organizações ferralíticas ai presentes (Lucas 
et al., 1996). Isto evidencia que são mais recentes e que sua expansão possivelmente esteja ligada ao desaparecimento progressivo das organizações ferralíticas. Sua gênese é atribuída a redistribuições e exportações de matéria, que se fazem em condições saturadas e redutoras, promovendo a perda de ferro e alumínio, sob a forma dissolvida e particular, e levam a uma acumulação residual de quartzo (Bravard \& Righi, 1988). Neste caso, os processos pedogeoquímicos têm sido considerados como motores essenciais da morfogênese nestas áreas, contribuindo para o aplainamento do terreno (Lucas et al., 1988).

Em resumo, uma evolução freqüentemente observada nas zonas tropicais úmidas, como a Amazônia, é a expansão das formações hidromórficas, a qual estaria associada a erosão química e mecânica consideráveis, causando regressão simultânea das formações ferralíticas e modificações sensíveis na morfologia das paisagens. $O$ desenvolvimento em cadeia destes processos seria capaz de modificar a carga em eletrólitos e em partículas dos sistemas de lençóis e, por conseguinte, a qualidade das águas dos grandes sistemas fluviais.

\subsection{Evolução mineralógica em ambiente tropical úmido com drenagem livre}

A alteração de rochas ácidas como o granito, que constitui grande parte do material de origem dos solos na região de estudo, leva normalmente, nas condições de clima quente e úmido, com drenagem livre, à formação de caulinita. Esse intemperismo pode ainda ocasionar a formação de gibbsita, em meio com drenagem rápida e com baixa atividade de $\mathrm{H}_{4} \mathrm{SiO}_{4}$ em solução (Macias \& Chesworth, 1992). A evolução dos constituintes da rocha é variável, sendo os feldspatos normalmente alterados para caulinita, haloisita e gibbsita. As micas evoluem para vermiculitas, caulinita, haloisita e goethita, sendo a biotita mais rapidamente intemperizada que a muscovita, em virtude da fácil oxidação do ferro, juntamente com hidrólise do magnésio (Eswaran \& Bin, 1978a,b,c; Cerri, 1979). 
A formação dos solos em meio tropical úmido e sem impedimento de drenagem é resultante principalmente do processo geoquímico de hidrólise, que se desenvolve em condições ácidas, normalmente com $\mathrm{pH}$ de 5 a 6 , provocando a dessilicatização intensa dos minerais primários. Dois estágios podem ser identificados, de acordo com intensidade de remoção da sílica. A hidrólise parcial ou monossialitização se caracteriza pela permanência de parte da sílica no sistema, que se combina com o alumínio, formando minerais do tipo $1: 1$, como a caulinita. No outro caso, tem-se a solubilização total da sílica, que se identifica como hidrólise total ou alitização, caracterizada pela permanência do alumínio, que se precipita formando gibbsita (Melfi \& Pedro, 1977).

A ação prolongada da hidrólise sobre materiais dispostos na superficie tem levado, em muitos casos, à formação de latossolos, que são solos com ampla distribuição geográfica na Amazônia. Os latossolos são definidos como solos minerais, ácidos, não hidromórficos, com horizonte B latossólico e, caracterizam-se pelo avançado estágio de intemperismo, sendo constituídos por sesquióxidos, minerais de argila $1: 1$ e minerais primários resistentes ao intemperismo; baixa relação silte/argila; baixa relação sílica/alumina (Ki) e argila de atividade baixa (EMBRAPA, 1999). Os latossolos normalmente são fortemente a bem drenados; são profundos e bem porosos; seqüência de horizontes $\mathrm{A}, \mathrm{B}$ e $\mathrm{C}$, com pouca diferenciação entre eles; transições difusas ou graduais; não apresentam cerosidade revestindo as unidades estruturais e possuem baixa relação textural.

\subsection{Hidromorfismo e alteração dos minerais}

O hidromorfismo é um processo pedogenético que atua em condições de excesso de água no solo, ocasionando aeração deficiente. Isto ocorre uma vez que a taxa de difusão do oxigênio na água é cerca de 10.000 vezes mais lenta do que nas condições atmosféricas. Como conseqüência da anaerobiose tem-se a redução do ferro ao estado ferroso $\left(\mathrm{Fe}^{2+}\right)$, o qual se torna solúvel, num processo conhecido como gleização. A solubilidade do íon ferroso é dependente do $\mathrm{pH}$ e do Eh da solução do solo, verificando- 
se, em condições de acidez crescente, a permanência do íon ferroso solúvel, mesmo com o aumento do estado de oxidação. O elemento solúvel pode ser removido do sistema, conferindo um aspecto acinzentado ao solo ou, ser deslocado a curtas distâncias, para zonas mais aeradas, onde o ferro se reoxida, formando manchas alaranjadas. Pode haver também precipitação progressiva, formando material plíntico ou concreções (Buol et al., 1997).

A alteração de condições de redução e oxidação no solo, que interfere na solubilidade do ferro, pode ser relacionada com a hidrólise de argilominerais, num processo conhecido como ferrólise. Inicialmente, em condições redutoras, ocorre a substituição dos cátions trocáveis pelo $\mathrm{Fe}^{2+}$, deslocando as bases $\mathrm{e} \mathrm{o}$ alumínio do complexo de troca para a solução. Na condição de oxidação, o $\mathrm{Fe}^{2+}$ transforma-se para $\mathrm{Fe}^{3+}$, aumentando a atividade de íons $\mathrm{H}^{+}$, o que induz a protólise das lâminas octaedrais dos argilominerais, em especial daqueles do tipo 2:1, tornando-os instáveis. Dependendo da quantidade de água que percola o solo na fase reduzida, maior quantidade de alumínio pode ser deslocado. Em pH maior do que 5,5, o alumínio removido precipita-se na forma de hidróxido, ocupando as entrecamadas de argilas do tipo 2:1, formando polímeros, que caracterizam os minerais cloritizados (Brinkman, 1970). Além da ferrólise, a perda de argila em meio hidromórfico pode se dar por argiluviação, que não envolve destruição das argilas, ou ainda pela acidólise e podzolização, em meio ácido, com pH inferior a 5 .

A dinâmica da matéria orgânica também é modificada em condições hidromórficas. A falta de oxigênio, que causa a diminuição do Eh, retarda a humificação e provoca uma evolução diferenciada da matéria orgânica, a semelhança do processo responsável pela formação das turfas (Duchaufour \& Souchier, 1983). Os ácidos fúlvicos e ácidos orgânicos hidrossolúveis formados nestas condições possivelmente interferem em processos de degradação dos minerais do solo (Ribeiro, 1998).

Os processos ligados à transformação de formações ferralíticas e à gênese de sistemas pedológicos do domínio hidromórfico nas zonas tropicais úmidas podem ser ordenados cronologicamente (Melfi et al., 1996), partindo-se da hidromorfia, seguida pela dissolução das argilas ou transporte detrítico (eluviação) e, finalmente, a 
podzolização. A hidromorfia acarreta dissolução seletiva dos oxi-hidróxidos de ferro, que se manifesta pela mudança progressiva na cor, com amarelecimento, seguido de embranquecimento e, pela perda progressiva da estrutura em agregados para matrizes maciças, menos porosas e pouco permeáveis, propícias ao encharcamento. Segue-se o processo de dissolução e/ou exportação em suspensão das argilas, desenvolvendo uma macroporosidade intersticial. Ela forma materiais permeáveis, arenosos e pouco coesos. A exportação de matéria é assegurada pela recarga e esvaziamento dos sistemas de lençóis. Finalmente o empobrecimento pode ser sucedido pela podzolização, que redistribui e exporta a matéria orgânica, acumulando o resíduo quartzoso (areias brancas).

\subsection{Podzolização: processo geoquímico e pedológico}

A podzolização é um processo comum em regiões boreais, ligada à baixa temperatura, que inibe a decomposição da matéria orgânica, em geral, associada a florestas de coníferas ou de ericáceas, que formam densa serapilheira. Nestes materiais predominam substâncias orgânicas ácidas e solúveis, que podem migrar no solo juntamente com metais como alumínio e ferro (Duchaufour \& Souchier, 1983). Nos trópicos, os podzóis ocorrem em regiões elevadas (podzóis de altitude) ou, em terras baixas, normalmente associadas à drenagem deficiente. Estes podzóis são pouco abundantes na África e ocorrem na Malásia, em ilhas da Indonésia, na Austrália e Nova Zelândia. Nas Américas, esses solos distribuem-se em porções da Flórida, nas Antilhas e na porção leste da América Central (Klinge, 1967). No Brasil, os podzóis ocorrem em extensas áreas na bacia do Rio Negro, em certas áreas do Pantanal e em ambientes de restinga (Gomes et al., 1998).

A formação dos podzóis tropicais, especialmente daqueles da Bacia Amazônica, é pouco conhecida em virtude da dificuldade de acesso e pela incapacidade de se abrirem trincheiras, devido a grande espessura $(5$ a $15 \mathrm{~m}$ ) da camada arenosa, presença de água e horizonte $\mathrm{Bh}$ endurecido e algumas vezes espesso (Dubroeucq \& Blancaneaux, 1987). 
A podzolização do ponto de vista geoquímico é um processo que consiste na destruição de minerais primários e secundários e translocação de materiais em direção ao subsolo. Tradicionalmente a translocação de materiais ocorreria na forma de quelatos de sesquióxidos com ácido fúlvico ou ácidos orgânicos de baixo peso molecular (De Coninck, 1980). Tem-se verificado, entretanto, que muitas vezes os metais podem mover-se na forma de aluminossilicatos amorfos, independente da matéria orgânica (Farmer et al., 1980). Mais recentemente tem-se constatado que a translocação de ferro e aluminio pode ocorrer por mecanismos orgânicos e inorgânicos, simultaneamente ou seqüencialmente (Jakobsen, 1991; Barrett, 1997).

A podzolização é também conhecida como acidólise total, caracterizada pela dissolução do alumínio dos minerais do solo, pela ação de soluções ácidas, com pH inferior a 4 , liberando $\mathrm{Al}^{3+}$ (forma iônica). Existe também um processo intermediário entre a podzolização e a hidrólise, que muitas vezes se manifesta em solos ácidos. Este processo é conhecido como aluminossialitização ou acidólise parcial, que ocorre quando as soluções apresentam pH entre 4 e 5 ( $\mathrm{pH}$ inferior a constante de hidrólise do alumínio, $\mathrm{pK}_{\mathrm{Al}}=5$ ). Neste caso, o alumínio removido é hidroxilado e pode acumular-se na forma de polímeros nas entrecamadas de argilominerais 2:1 (Bonneau \& Souchier, 1994).

Do ponto de vista pedológico, o termo podzol veio do russo e significa pod (inferior) e zola (cinza), designando solos florestais do norte da Rússia, com uma camada arenosa clara (eluvial) logo abaixo da superficie. Abaixo deste material desenvolve-se um horizonte de acúmulo de matéria orgânica e/ou compostos de alumínio de ferro (De Coninck \& Righi, 1983). Esses solos, genericamente, podem ser agrupados em drenados ou hidromórficos. Em meio drenado e oxidante, o horizonte espódico é composto por ácidos fúlvicos ligados ao alumínio e complexos com ferro como principais constituintes amorfos. Em meio hidromórfico as condições de redução ocasionam a perda de ferro e, os constituintes principais são os ácidos húmicos associados ao alumínio (McKeague et al., 1986).

Os processos responsáveis pela formação do horizonte $\mathrm{Bh}$ em solos drenados e hidromórficos são discutidos por Farmer et al. (1983). Segundo estes autores, em meio drenado, o horizonte $\mathrm{Bh}$ é mais rico em ferro, que ocorre juntamente com a 
matéria orgânica, revestindo os grãos, normalmente sem o preenchimento dos vazios intergranulares. Sua formação neste caso prescinde da presença de fontes de ferro e alumínio no horizonte superficial, que se movem na forma solúvel ou coloidal, precipitando-se em subsuperfície por efeito de reoxidação e neutralização de cargas do metal e da matéria orgânica. Os tipos de horizonte B formados nestas condições são tipicamente o B plácico e B nodular (De Coninck \& Righi, 1983).

No caso dos podzóis hidromórficos, que são os predominantes na região do alto Rio Negro, a morfologia do horizonte Bh, caracteriza-se pelo preenchimento dos espaços entre os grãos com precipitados orgânicos, mantendo o esqueleto limpo, sem revestimentos. Sua formação pode ocorrer a partir de materiais de origem pobres em sesquióxidos e a precipitação em subsuperficie se dá em condições de permanente saturação. O mecanismo de formação do horizonte $\mathrm{Bh}$ pode ser explicado, nestas condições, pela precipitação de suspensões ricas em matéria orgânica proveniente de águas superficiais, combinadas com $\mathrm{Al}$ presente em soluções de subsuperficie (Farmer et al., 1983). As formas do horizonte $\mathrm{B}$ neste caso são o Bh cimentado e o friável (De Coninck \& Righi, 1983). Os horizontes espódicos friáveis normalmente estão associados à maior atividade biológica, contendo matéria orgânica com menor idade, em relação aos materiais cimentados. A evolução da cimentação depende da intensidade relativa de dois processos opostos, que são a pedoturbação e a iluviação de materiais orgânicos e minerais. O primeiro tende a manter solto o horizonte e o segundo favorece a cimentação. No caso do processo de iluviação mais ativo que o de mistura pela ação da fauna (biopedoturbação), o horizonte B tornar-se-ia gradualmente cimentado, impedindo a penetração de raizes e a atividade biológica. A continuidade desse processo levaria à fossilização do horizonte.

\subsection{O sistema latossolo-podzol}

Os solos ferralíticos presentes nas zonas tropicais úmidas são freqüentemente associados aos podzóis, com relatos em diversas regiões da América do Sul (Klinge, 1965; Volkoff, 1985), na África (Brammer, 1973; Schwartz, 1987), e na 
Indonésia (Brabant, 1987; Thomas et al., 1999). Na região amazônica, o reconhecimento pedológico evidencia extensas áreas com solos podzolizados. Segundo EMBRAPA (1981), somente no Amazonas e em Roraima existem mais de $100.000 \mathrm{~km}^{2}$ de podzóis hidromórficos e areias quartzosas hidromórficas. Esses solos invadem quase toda a paisagem, com exceção de algumas colinas cobertas em geral por Latossolos Amarelos, que atingem cerca de uma dezena de metros em relação à superfície aplainada adjacente (Gavaud et al., 1986; Dubrouecq \& Blancaneaux, 1987).

Inicialmente, pensava-se que os podzóis tropicais somente se desenvolvessem a partir de rochas arenosas, tais como quartzitos, arenitos ou outros materiais resultantes de coluvionamento e transporte eólico ou hidrico. No caso dos podzóis e outros solos arenosos que ocorrem nas baixadas da bacia amazônica, sua formação foi inicialmente atribuida à deposição de sedimentos nas bordas dos vales (Klinge, 1965; Sombroek, 1984). Em contraposição a essa hipótese de origem sedimentar, vários estudos conduzidos na Guiana Francesa e no Brasil têm mostrado que os podzóis podem ser formados pela transformação de uma cobertura ferralitica inicial, sobre vários tipos de material de origem (Lucas et al., 1984; Andrade, 1990; Dubroeucq et al., 1991). Neste caso o podzol é considerado como um estágio final de degradação das coberturas pedológicas tropicais (Boulet et al., 1984).

Do ponto de vista geoquimico, a distribuição ordenada dos solos na paisagem, sugere a existência de uma evolução geral na escala da Bacia Amazônica, associada a redistribuições e exportações de matéria, principalmente ferro, argila e matéria orgânica, que iria se desenvolvendo a partir da base das vertentes em direção ao centro dos platôs. A evolução geoquimica pode ser relacionada com o aplainamento geral da superfície em virtude da transformação lateral das coberturas ferraliticas por intemperismo em condições de estabilidade tectônica, por longo período sob clima tropical úmido. Nestas condições, os latossolos sofreriam intensa degradação por ação de soluções ácidas, transformando-se lateralmente em podzóis e outros solos arenosos (Dubroeucq et al., 1999). 


\subsection{Caracterização do meio físico: a bacia do Rio Negro}

A bacia do Rio Negro situa-se entre latitudes $1^{\circ} \mathrm{S}$ e $4^{\circ} \mathrm{N}$ e longitudes $70^{\circ} \mathrm{W}$ e $66^{\circ} \mathrm{W}$. A porção montante desta bacia (alto Rio Negro) distribui-se no Brasil, Colômbia e Venezuela, sendo constituída por uma planície, em grande parte coberta por solos arenosos e hidromórficos (Dubroeucq et al., 1999).

O substrato geológico pertence ao embasamento cristalino, formado no Pré-Cambriano e, a unidade geotectônica presente, é chamada de Cráton Guianês ou Escudo da Guiana. A litologia é composta por um conjunto de rochas ígneas e metamórficas, intensamente dobradas, falhadas e profundamente erodidas, compondo a unidade litoestratigráfica conhecida como Complexo Guianense, o qual demonstra complexidade estrutural, metamórfica e geocronológica. As rochas que ai ocorrem apresentam um estágio avançado de granitização, caracterizadas por uma textura homogênea granular ou porfiroblástica (Brasil, 1976).

As características geomorfológicas são representadas por um conjunto de relevo bastante homogêneo onde predominam extensas áreas aplainadas, cuja formação seria resultante de processos de pediplanação (Franco et al., 1975). Segundo estes autores, estas áreas pertencem a unidade morfoestrutural do Pediplano Rio Branco-Rio Negro, considerada uma das mais abrangentes unidades geomorfológicas da Amazônia, totalizando cerca de $280.000 \mathrm{~km}^{2}$, somente no Brasil, estendendo-se também na Colômbia e Venezuela. Essa unidade apresenta altitudes entre 80 a 160 m, formando um conjunto de relevo homogêneo, com extensas áreas aplainadas e emergência isolada de inselbergues graníticos, cristas de quartzitos e algumas colinas convexas A formação dessa superficie, segundo a interpretação desses geomorfólogos, é atribuída a processos erosivos desenvolvidos durante o Paleozóico, que expuseram a base do bloco, que constitui o Cráton Guianês. Sobre essa superfície plana teria ocorrido a deposição de uma cobertura arenosa, de idade pleistocênica, resultante de agentes erosivos manifestados em condições paleoclimáticas com estação seca pronunciada (Brasil, 1976). Esta interpretação é contrária aos estudos pedológicos desenvolvidos mais recentemente, que apontam para uma formação "in situ" das areias, por processos 
pedogeoquímicos (Segalen, 1994). Essas superficies têm sofrido modificações recentes pela ação de eventos tectônicos, que se evidenciam em mudanças bruscas na direção dos cursos d'água (Costa et al., 1996), o que pode ter ocasionado o rebaixamento relativo de muitas áreas, modificando a dinâmica dos solos pela criação de ambientes hidromórficos.

Com relação ao clima, a região do alto Rio Negro apresenta elevados índices de precipitação pluviométrica, variando de 3000 e 4000 mm anuais, sem estação seca marcada e com aumento da intensidade de chuva em maio-junho. $\mathrm{O}$ excesso hídrico varia de 1000 a $2000 \mathrm{~mm}$ anuais. O regime de umidade do solo é údico a perúdico na maior parte da área (Estados Unidos, 1998). As temperaturas médias anuais situam-se entre $24^{\circ}$ e $26^{\circ} \mathrm{C}$, com amplitude das médias mensais inferior a $5^{\circ} \mathrm{C}$, caracterizando um regime isotérmico. A umidade relativa do ar apresenta médias mensais de 85 a $90 \%$. Segundo a classificação de Köppen, o clima é do tipo tropical chuvoso constantemente úmido (Afi). A conjugação de aspectos climáticos e de vegetação, levados em conta na classificação de Gaussen, define o bioclima da região de estudo como Eutermaxérico ou Equatorial propriamente dito (Brasil, 1976). As variações paleoclimáticas regionais foram pouco evidentes durante o Quaternário (Colinvaux et al., 1996).

A vegetação é caracterizada por formações essencialmente primárias, composta por dois grupos fisionômicos principais, em dependência das diferenças geomorfológicas e florísticas. O primeiro é a floresta tropical densa que aparece nos terrenos elevados e drenados, como nas colinas. É caracterizada por apresentar árvores de grande porte que emergem de um estrato arbóreo uniforme de 25 a $35 \mathrm{~m}$ de altura. $\mathrm{O}$ segundo grupo é a campinarana, também conhecida como "Caatinga do Rio Negro", que predomina nas áreas aplainadas, onde aparecem os Podzóis Hidromórficos. As campinaranas são divididas em dois subgrupos, a formação arbórea densa, composta por árvores finas e densamente distribuídas e, a formação arbórea aberta, de menor porte, com algumas concentrações de plantas formando tufos lenhosos. Outros tipos intermediários de vegetação compõem os refúgios ecológicos e as áreas de tensão ecológica (Brasil, 1976). 
O mapa de solos do alto Rio Negro evidencia amplos domínios com solos arenosos, tais como podzóis gigantes e podzóis hidromórficos, compondo a superfície de aplainamento onde emergem as coberturas ferralíticas, compostas por latossolos. Os estudos pedológicos regionais possibilitaram a descrição de várias unidades pedogeomórficas. As áreas mais altas em relação ao plano geral são formadas por terrenos com elevações policonvexas, que atingem até $80 \mathrm{~m}$ de altura e chegam a $800 \mathrm{~m}$ de diâmetro, nas quais os Latossolos Vermelho-Amarelos são predominantes. Outros terrenos são caracterizados pela ocorrência de colinas mais baixas, com menos de 30 metros de altura, cobertas por latossolos que freqüentemente apresentam concreções gibbsíticas. Uma outra unidade pedogeomórfica é constituída por superfícies aplainadas, onde aparecem elevações isoladas, com 2 a $15 \mathrm{~m}$ de altura, circundadas pelo plano arenoso. A maior parte da área é constituída por uma planície hidromórfica, com presença de areias brancas não estratificadas, formando podzóis gigantes que podem atingir cerca de $10 \mathrm{~m}$ de profundidade (Dubroeucq \& Volkoff, 1998; Dubroeucq et al., 1999). Todas estas superficies apresentam-se ordenadamente distribuídas na escala regional, sugerindo a existência de relação pedogenética entre elas (Grzebyk \& Dubroeucq, 1994).

Uma das principais características dos solos nas áreas planas é a precariedade do escoamento superficial da água, dificultando a abertura e o entalhe de talvegues, criando condições de hidromorfismo, que propicia um ambiente favorável à podzolização (Gavạud et al., 1986). 


\section{MATERIAL E MÉTODOS}

\subsection{Local de estudo}

- Escolha da área

A escolha da área de estudo foi feita observando-se os tipos de solo, vegetação, material de origem e relevo. As formas do relevo foram observados em imagens de radar, na escala 1:250.000 e imagens de satélite, tipo "Landsat", empregando-se os canais 6 e 7. O local escolhido situa-se próximo a vila de Cucuí, próximo à divisa com a Venezuela, com coordenadas: $01^{\circ} 07^{\prime} 48^{\prime \prime} \mathrm{N}$ e $66^{\circ} 48^{\prime} 29^{\prime \prime} \mathrm{W}$ (Figura 1). O terreno é em sua maior extensão constituído de uma planície hidromórfica, com algumas colinas baixas $(3 \mathrm{~m})$ com solos relativamente argilosos e drenados.

- Substrato geológico, clima e vegetacão

O substrato geológico local é composto por granito cinzento, com granulação fina ( 1 a $3 \mathrm{~mm}$ ) e algumas porções com estrutura porfiritica, pertencente ao Complexo Guianense, que ocorre na forma de matacões em subsuperficie no latossolo e em afloramentos na periferia de colina.

O clima é do tipo tropical chuvoso constantemente úmido (Afi), segundo a classificação de Köppen. A precipitação média observada em São Gabriel da Cachoeira é de $2903 \mathrm{~mm}$ por ano, sem ocorrência de estação seca. A evapotranspiração potencial é de $1432 \mathrm{~mm}$ e o excesso hídrico é de $1471 \mathrm{~mm}$ anuais (Figura 2). As temperaturas médias anuais situam-se entre $24^{\circ}$ e $26^{\circ} \mathrm{C}$, com amplitude térmica anual insignificante. A umidade relativa do ar é caracterizada por elevado grau de saturação, com médias mensais em torno de 85 a $90 \%$ (Brasil, 1976). 

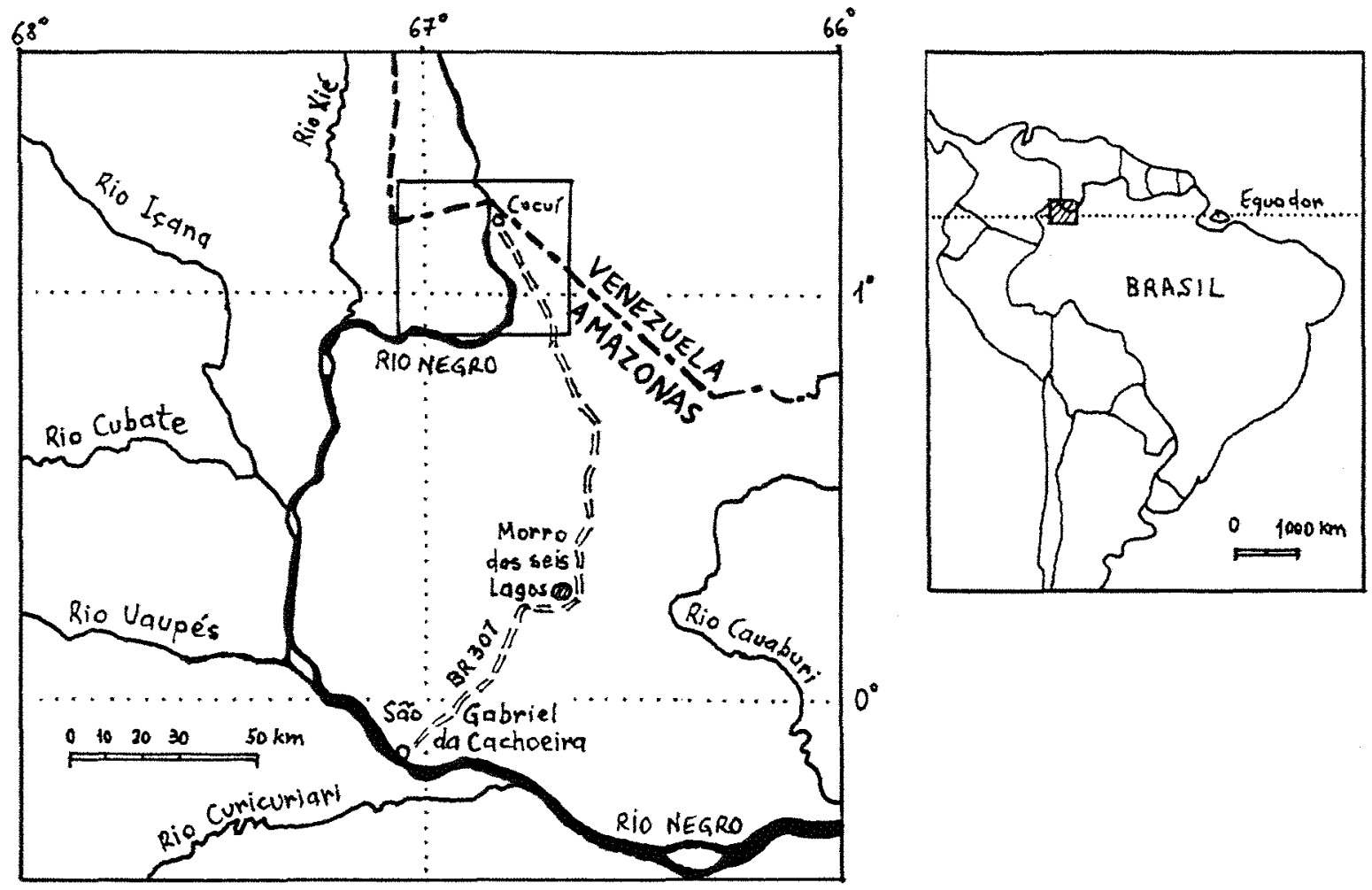

Legenda:

Associação Latossolos textura média, Podzólicos textura média e Podzóis Hidromórficos; relevo suave ondulado; contato floresta-campinarana

嗞 Podzóis Hidromórficos e Areias Quartzosas Hidromórficas; relevo plano; campinarana

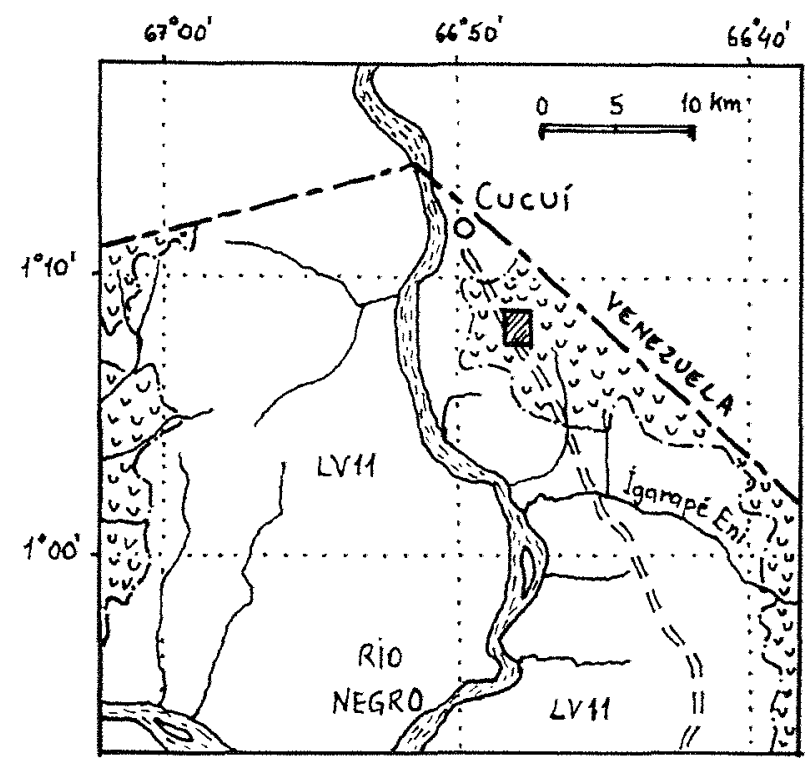

Figura 1 - Localização da área de estudo na região do Alto Rio Negro, AM, com indicações dos tipos de solo, relevo e vegetação (Brasil, 1976). 


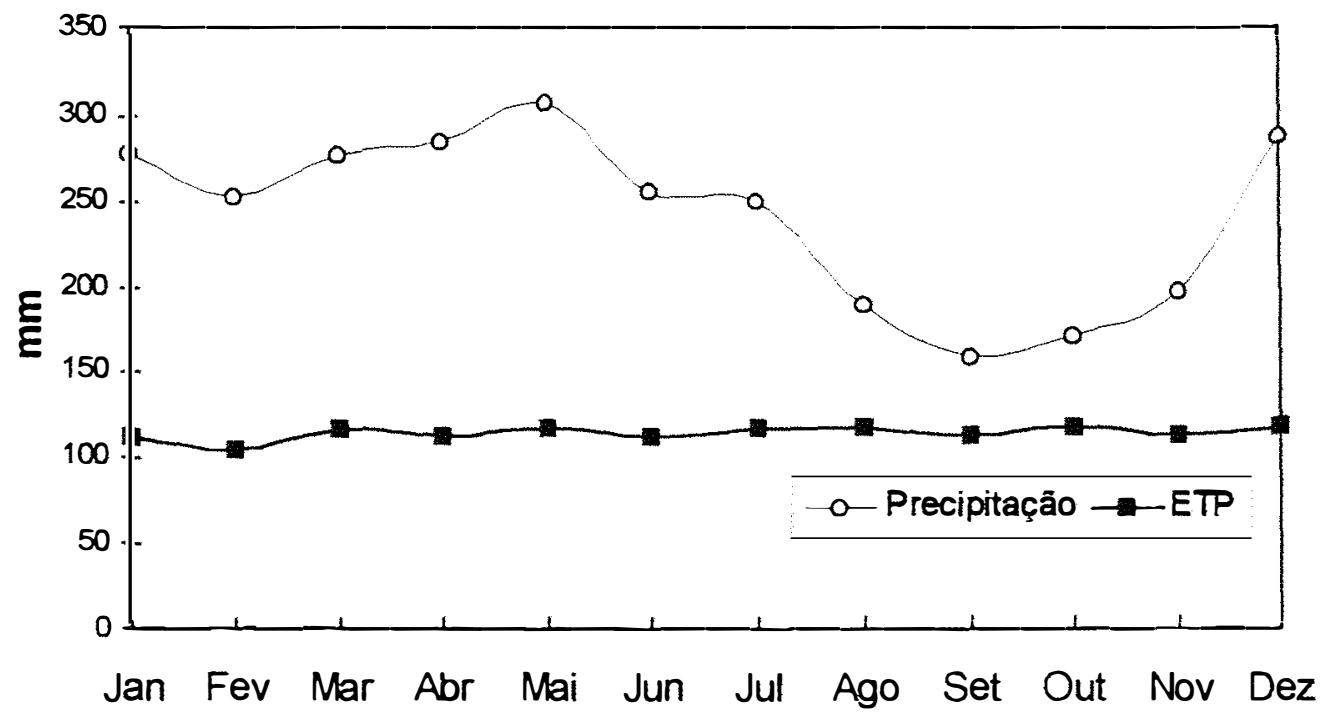

Figura 2 - Representação do balanço hídrico normal decendial para São Gabriel da Cachoeira, AM; Lat. $00^{\circ} 08^{\prime}$ S e long. $67^{\circ} 05^{\prime} \mathrm{W}$ (Brasil, 1976).

A formação vegetal típica na região de estudo é campinarana caracterizada pelo elevado número de arbustos na submata e pela homogeneidade do estrato arbóreo (Rodrigues, 1961). Esta vegetação se encontra intimamente associada às áreas arenosas, com solos ácidos e extremamente pobres em nutrientes (Lisboa, 1975). $\mathrm{Na}$ colina a vegetação é representada por floresta de terra firme, aparecendo árvores de maior diâmetro e sub-bosque adensado.

\subsection{Caracterização da cobertura pedológica}

O estudo detalhado dos solos e de seus constituintes ao longo de uma seqüência latossolo-podzol foi feito com base na análise estrutural da cobertura pedológica (Boulet et al., 1982), que compreende o reconhecimento, observação, medição, caracterização e representação espacial real, como também a interpretação das organizações morfológicas do solo. Inicialmente procedeu-se o levantamento topográfico altimétrico do terreno, realizado em uma quadrícula com malha de $25 \mathrm{~m}$ englobando a colina central. A cobertura vegetal, o aspecto superficial do terreno e a atividade biológica do solo foram descritos. 
A organização da cobertura pedológica foi caracterizada em duas seqüências perpendiculares entre si, com sete trincheiras, abrangendo os solos numa colina baixa e no plano circundante. A variabilidade espacial dos solos foi avaliada na colina com uso de trado comum. Na planície hidromórfica foi utilizado um amostrador metálico introduzido no solo por percussão, possuindo quatro centimetros de diâmetro, dois metros de comprimento, e sistema de vedação na parte superior (rolha de borracha). A distância máxima entre tradagens e/ou sondagens foi de 25 metros. Os aspectos macromorfológicos, como cor, estrutura, distribuição de raizes, textura, porosidade e consistência do solo foram identificados (Lemos \& Santos, 1996). Essa descrição prévia e caracterização dos diferentes horizontes orientou os locais de coleta de amostras para descrição micromorfológica e analitica.

As amostras indeformadas e orientadas foram coletadas em locais representativos dos diferentes materiais, sendo posteriormente secas em estufa a $40^{\circ} \mathrm{C}$ e impregnadas com resina araldite sob vácuo. Após o endurecimento as amostras foram cortadas e montaram-se lâminas delgadas (Castro, 1985). A terminologia empregada é baseada em Bullock et al. (1985) e Lima et al. (1985).

A interferência das minhocas na superficie do solo foi avaliada pela contagem e medida dos montículos superficiais em duas áreas distintas no plano hidromórfico, a leste e a oeste da colina. As áreas eram quadradas, de $10 \times 10 \mathrm{~m}$, subdivididas em 25 parcelas de $4 \mathrm{~m}^{2}$. As medidas efetuadas nos montículos foram diâmetro médio na base e altura. $\mathrm{O}$ volume de terra presente nestas estruturas foi calculado considerando-se o formato cònico.

\subsection{Métodos analíticos}

- Atributos físicos e químicos do solo

Os atributos fisicos analisados foram a densidade do solo $\mathrm{e}$ a granulometria. A densidade do solo foi estimada em amostras coletadas em anéis volumétricos de $100 \mathrm{~cm}^{3}$, obtendo-se a massa de solo por secagem em estufa à $110^{\circ} \mathrm{C}$. A granulometria foi determinada pela separação prévia do cascalho e dispersão da terra 
fina, inferior a $2 \mathrm{~mm}$ com hidróxido de sódio $\left(5 \mathrm{~g} \mathrm{~L}^{-1}\right)$ e hexametafosfato de sódio (10 $\mathrm{g}$ $\left.\mathrm{L}^{-1}\right)$. As areias foram separadas por peneiramento, em cinco classes: areia muito grossa, de 2 a $1 \mathrm{~mm}$; areia grossa, de 1 a $0,5 \mathrm{~mm}$; areia média, de 0,50,25 mm; areia fina, de 0,25 a $0,1 \mathrm{~mm}$ e areia muito fina, de 0,1 a $0,25 \mathrm{~mm}$. A argila foi determinada pelo método do densímetro e o silte foi calculado por diferença (Camargo et al., 1986).

A partir das distribuições percentuais das cinco frações de areia foram calculados o diâmetro médio e o desvio padrão, de acordo com Folk \& Ward (1957). Os valores de granulometria foram analisados pelo programa "Phi" para microcomputadores (Van Lier \& Vidal-Torrado, 1992). Estes resultados auxiliam na interpretação da uniformidade dos materiais de origem do solo e foram aplicados no estudo da filiação dos solos ao granito subjacente.

A caracterização química do solo compreendeu uma série de determinações. Mediu-se o pH das amostras em água e em $\mathrm{KCl} 1 \mathrm{~N}$. A bases trocáveis $\left(\mathrm{Ca}^{2+}, \mathrm{Mg}^{2+} \mathrm{e} \mathrm{K}^{+}\right)$foram extraídas por resina trocadora de íons, com determinação de

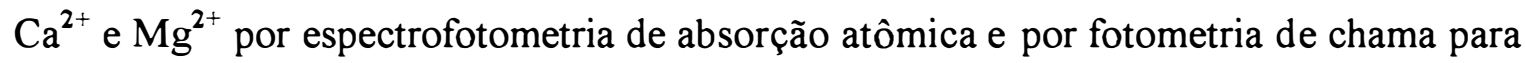
o $\mathrm{K}^{+}$. A matéria orgânica foi determinada por oxidação úmida com dicromato de potássio em ácido sulfúrico. $\mathrm{O} \mathrm{Al}^{3+}$ trocável foi extraído com $\mathrm{KCl} 1 \mathrm{~N}$ e a acidez potencial $\left(\mathrm{H}^{+}+\mathrm{Al}^{3+}\right)$ foi extraida com acetato de cálcio a $\mathrm{pH}$ 7,0. A partir desses resultados foram calculadas a capacidade de troca catiônica (CTC), saturação por bases (V) e saturação por $\mathrm{Al}(\mathrm{m})$. Os teores de $\mathrm{Si}, \mathrm{Al}$, Fe e Ti foram determinados após solubilização com $\mathrm{H}_{2} \mathrm{SO}_{4}$ 1:1, possibilitando o cálculo dos índices $\mathrm{Ki}$ e $\mathrm{Kr}$. O teor de óxidos de ferro foi determinado após extração com citrato-bicarbonato-ditionito de sódio. Os óxidos de ferro amorfos foram analisados após extração com solução ácida de oxalato de amônio (Camargo et al., 1986; EMBRAPA, 1997). As análises físicas e químicas do solo foram feitas no Departamento de Solos e Nutrição de Plantas (ESALQ/USP).

- Mineralogia do solo

Os minerais do solo foram caracterizados, na fração areia muito fina e cascalho por microscopia ótica e nas frações silte e argila, por difratometria de raio-X. As 
amostras foram tratadas com água oxigenada $30 \%$ à quente para remoção da matéria orgânica. A remoção do ferro livre foi feita com solução de citrato-bicarbonato-ditionito de sódio. Após eliminação da matéria orgânica e ferro as amostras foram dispersas com $\mathrm{NaOH}$ $0,1 N$, procedendo-se a separação das areias por peneiramento, e do silte e argila por centrifugação. As amostras de argila deferrificada foram saturadas com $\mathrm{K} \mathrm{e} \mathrm{Mg,} \mathrm{montadas}$ em lâminas orientadas e irradiadas de 5 a $30 \mathrm{CuK} \alpha{ }^{\circ} 2 \theta$. O silte foi montado na forma de pó e irradiado de 5 a $60 \mathrm{CuK}^{\circ}{ }^{\circ} 2 \theta$, num difratômetro "Philips PW 1830", a $30 \mathrm{~mA}$ e $40 \mathrm{kV}$. A velocidade de irradiação foi de $2^{\circ} 2 \theta$ por minuto. A confirmação da presença de gibbsita e caulinita e a avaliação da quantidade de hidróxidos de Al nas entrecamadas de minerais 2:1 foi realizada, quando necessário, pelo aquecimento das lâminas saturadas com $\mathrm{K}$, a $110^{\circ} \mathrm{C}$, $350^{\circ} \mathrm{C}$ e $550^{\circ} \mathrm{C}$ (Camargo et al., 1986). As amostras saturadas com Mg que apresentaram reflexos entre 1,2 e 1,4 nm foram fervidas com citrato de sódio para eliminação dos polímeros de $\mathrm{Al}$ das entrecamadas, sendo ressaturadas com $\mathrm{Mg}$ e deixadas em vapor de etilenoglicol e, em seguida irradiadas para verificar a presença de argilominerais expansivos (Tamura, 1957). A identificação dos óxidos de ferro foi feita por difração de raios $\mathrm{X}$ em amostras da fração argila fervidas com $\mathrm{NaOH} 5 \mathrm{M}$ para eliminar caulinita, gibbsita e material amorfo. O procedimento para difração dos óxidos foi semelhante ao utilizado para a fração silte (Camargo et al., 1986). A identificação dos minerais nos difratogramas foi realizada com base em Thorez (1976); Brown \& Brindley (1980) e Moore \& Reynolds (1989).

A estimativa da concentração de gibbsita e caulinita na fração argila foi feita por análise térmica diferencial (ATD), em amostras livres de matéria orgânica e óxidos de ferro, e saturadas com $\mathrm{Mg}$. A quantificação baseou-se nas áreas dos picos endotérmicos, a $320{ }^{\circ} \mathrm{C}$ para gibbsita e a $550{ }^{\circ} \mathrm{C}$ para caulinita, calculados em relação a uma curva padrão com concentrações crescentes para cada um destes minerais (Camargo et al., 1986).

\section{- Microscopia eletrônica de varredura}

Os constituintes minerais e a superficie dos grãos de areia $(0,25$ a $0,5 \mathrm{~mm})$ foram observados ao microscópio eletrònico de varredura, com identificação dos elementos por microssonda. As amostras foram recobertas com ouro em um evaporador 'Daton 
Vacuum Desk II" e o microscópio utilizado foi um "Jeol KGM 5600LV", acoplado à microssonda "Noran", com detector de fluoreto de lítio. As análises ao microscópio eletrônico e de difratometria de raio-X foram efetuadas no Núcleo de Pesquisa em Geoquimica e Geofísica da Litosfera (NUPEGEL/ESALQ/USP).

\section{- Exame morfoscópico dos grãos de quartzo}

A descrição morfoscópica dos grãos de quartzo nas areias visando avaliar a uniformidade dos materiais foi feita ao microscópio ótico, em lâminas delgadas e em grãos dispostos sobre lâmina de vidro para os materiais não impregnados. $\mathrm{O}$ arredondamento, a esfericidade e o aspecto superficial dos grãos foram estimados por comparação (Suguio, 1973). As freqüências de arredondamento e esfericidade nas frações areia grossa (2-0,25 $\mathrm{mm})$ e areia fina $(0,25-0,05 \mathrm{~mm})$ foram multiplicadas pelos valores médios dos intervalos de classe (Krumbein \& Sloss, 1963). As classes de arredondamento consideradas foram: angular $(<0,2)$; subangular $(0,21-0,4)$; subarredondada $(0,41-0,6)$; arredondada $(0,61-0,8)$ e bem arredondada $(>0,8)$. Para esfericidade foram consideradas quatro classes: bastonada $(<0,4)$; tabular $(0,41-0,6)$; ovalada $(0,61-0,8)$ e eqüidimensional $(>0,8)$. A partir do produto das frequêencias e dos valores médios dos intervalos de classe foram obtidas as médias ponderadas de arredondamento e esfericidade por fração granulométrica (Suguio, 1973).

\section{- Composicão química das águas}

O estudo exploratório dos íns em solução no solo foi feito pela coleta de amostras de água em cinco posições nas sequeências de solo: a) topo da colina, no nível lençol freático; b) borda da colina; c) duas amostras na planície hidromórfica, uma na parte leste e outra a oeste da colina e d) eixo de drenagem, no riacho que drena a área. As amostras da borda da colina, do plano e do riacho foram coletadas na camada superficial, de 10 a $20 \mathrm{~cm}$ de profundidade. As águas foram coletadas em dois dias distintos, esperando-se um tempo após as chuvas intensas para evitar diluição. Em seguida as amostras foram filtradas com membrana "Millipore" com 0,22 $\mu \mathrm{m}$ de diâmetro de poro, sob vácuo. A aliquota destinada à análise dos cátions foi acidificada com $\mathrm{HNO}_{3}$, na proporção de $1 \%$ em volume. As amostras foram conservadas sob refrigeração a $4^{\circ} \mathrm{C}$. 
Os íons maiores em solução $\left(\mathrm{Al}^{3+}, \mathrm{Mg}^{2+}, \mathrm{Ca}^{2+}, \mathrm{Na}^{+}, \mathrm{K}^{+}, \mathrm{NH}_{4}{ }^{+}, \mathrm{SO}_{4}{ }^{2-}, \mathrm{NO}_{3}{ }^{-} \mathrm{e}\right.$ $\mathrm{Cl}^{-}$), foram dosados por cromatografia líquida, com um equipamento "Dionex DX500" do Instituto Astronômico e Geofísico (IAG/USP), em São Paulo, SP. Para os cátions foi utilizada uma coluna separadora CS12 e ácido metanosulfônico como eluente. Para os ânions a coluna separadora AS4A foi empregada, com uso de solução de carbonato/bicarbonato de sódio como eluente, sendo analisados num detetor eletroquímico. Para os metais foi utilizado um detetor UV/Vis, coluna separadora CS5A, reação póscoluna com 4-(2-piridilazol) resorcinol e eluente PDCA (piridina ácido dicarboxilico) e comprimento de onda de $530 \mathrm{~nm}$ no visivel; para o $\mathrm{Al}^{3+}$ a coluna separadora foi a mesma e eluente ácido sulfúrico/sulfato de amônio e reação pós coluna em pirocatecol violeta em $530 \mathrm{~nm}$ no visível (Weiss, 1986). A precisão das análises foi, em média, superior a $90 \%$. A acuracidade foi medida utilizando-se amostras certificadas de referência.

A mobilidade do alumínio na água foi calculada pelo produto da concentração em solução e o excesso hídrico do solo. Para o cálculo do excesso considerou-se como sendo a diferença entre a precipitação e a evapotranspiração potencial (ETP), que é semelhante a evapotranspiração real nas condições locais de solo coberto por densa vegetação (Villa Nova et al., 1976). Os valores de precipitação e ETP foram provenientes do Município de São Gabriel da Cachoeira, AM (Brasil, 1976).

\subsection{Classificação dos solos}

Os perfis representativos dos materiais, descritos e analisados na colina e na planície hidromórfica, foram classificados de acordo com o Sistema Brasileiro de Classificação de Solos (EMBRAPA, 1999), até o $5^{\circ}$ nivel categórico, correspondente a família. 


\section{RESULTADOS}

\subsection{Aspecto superficial do terreno e morfologia das vertentes}

A área de estudo situa-se numa planície com predomínio de solos arenosos hidromórficos, que circundam algumas colinas baixas com solos do tipo latossolo. As vertentes estudadas abrangiam desde o topo de uma colina baixa e estendiam-se até a superficie aplainada (Figura 3).

\section{a) $\underline{\text { Colina }}$}

A colina tem formato arredondado, mais alongada na direção noroestesudoeste, com área de 0,6 ha e altura próxima a $3 \mathrm{~m}$ em relação à planície hidromórfica circundante. $\mathrm{O}$ formato superficial do terreno é ligeiramente convexo e os declives variam de 0,05 a $0,08 \mathrm{~m} / \mathrm{m}$. Os maiores declives localizam-se na porção leste da área, a qual é ladeada pelo eixo principal de drenagem. As bordas da colina são recortadas, ora extremamente irregulares (com reentrâncias e digitações), ora arredondadas (limites regulares), com aspecto geral amebóide e digitado (Figura 4).

Os solos da colina são amarelados e argilosos, com uma camada superficial de serapilheira. A vegetação é do tipo floresta densa de terra firme.

\section{b) Contato colina-planície hidromórfica}

A zona de contato entre a colina e a planície hidromórfica apresenta variações quanto a forma e desnivel do terreno, profundidade da rocha e emergência de matacões e afloramentos do granito nos solos da planície. Com base nestas características, cinco tipos de contatos foram identificados. 


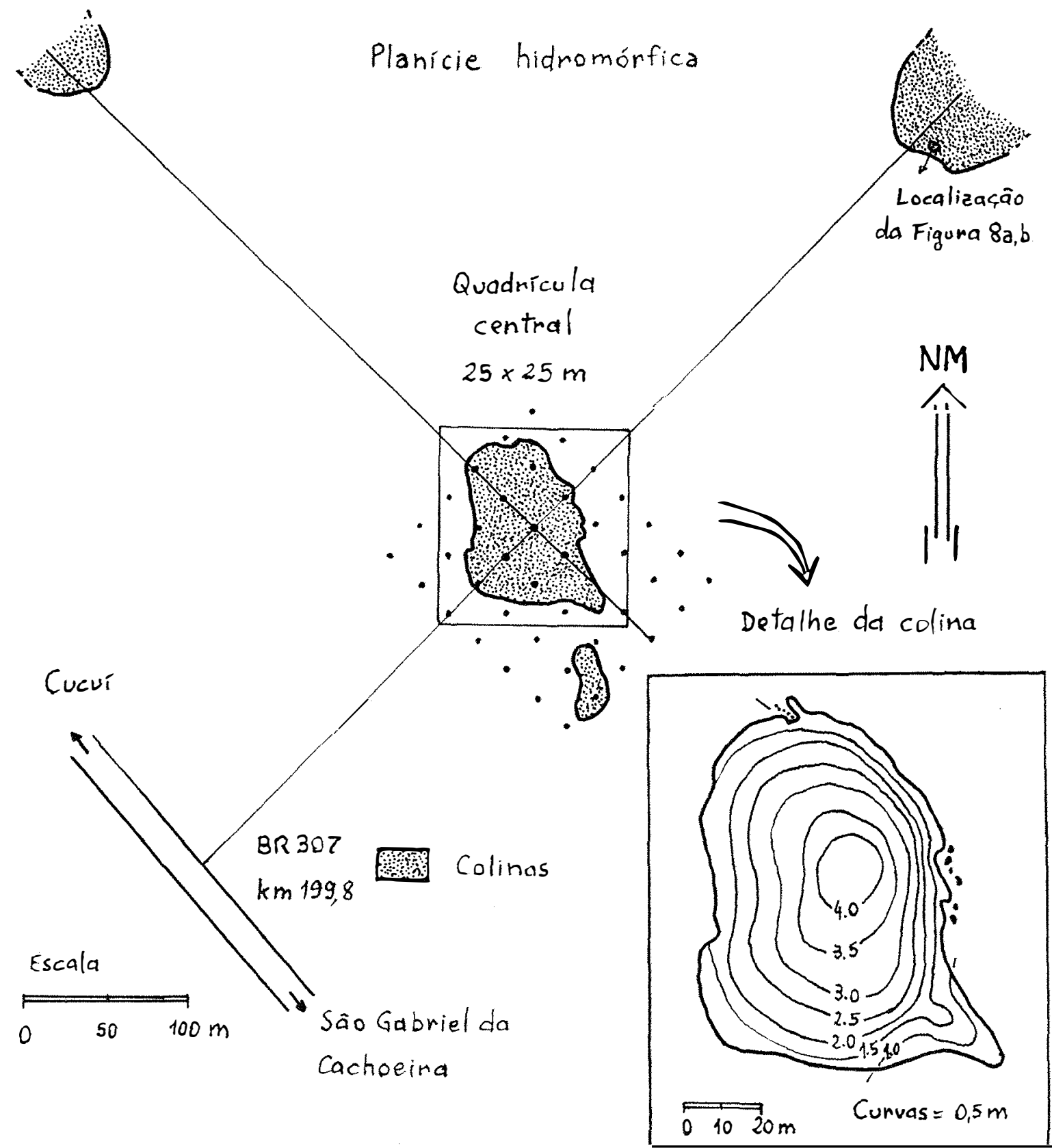

Figura 3 - Localização geral da área de estudo nas proximidades de Cucuí, AM, com detalhes dos alinhamentos levantados e da distribuição das colinas baixas em relação à planície hidromórfica circundante. 

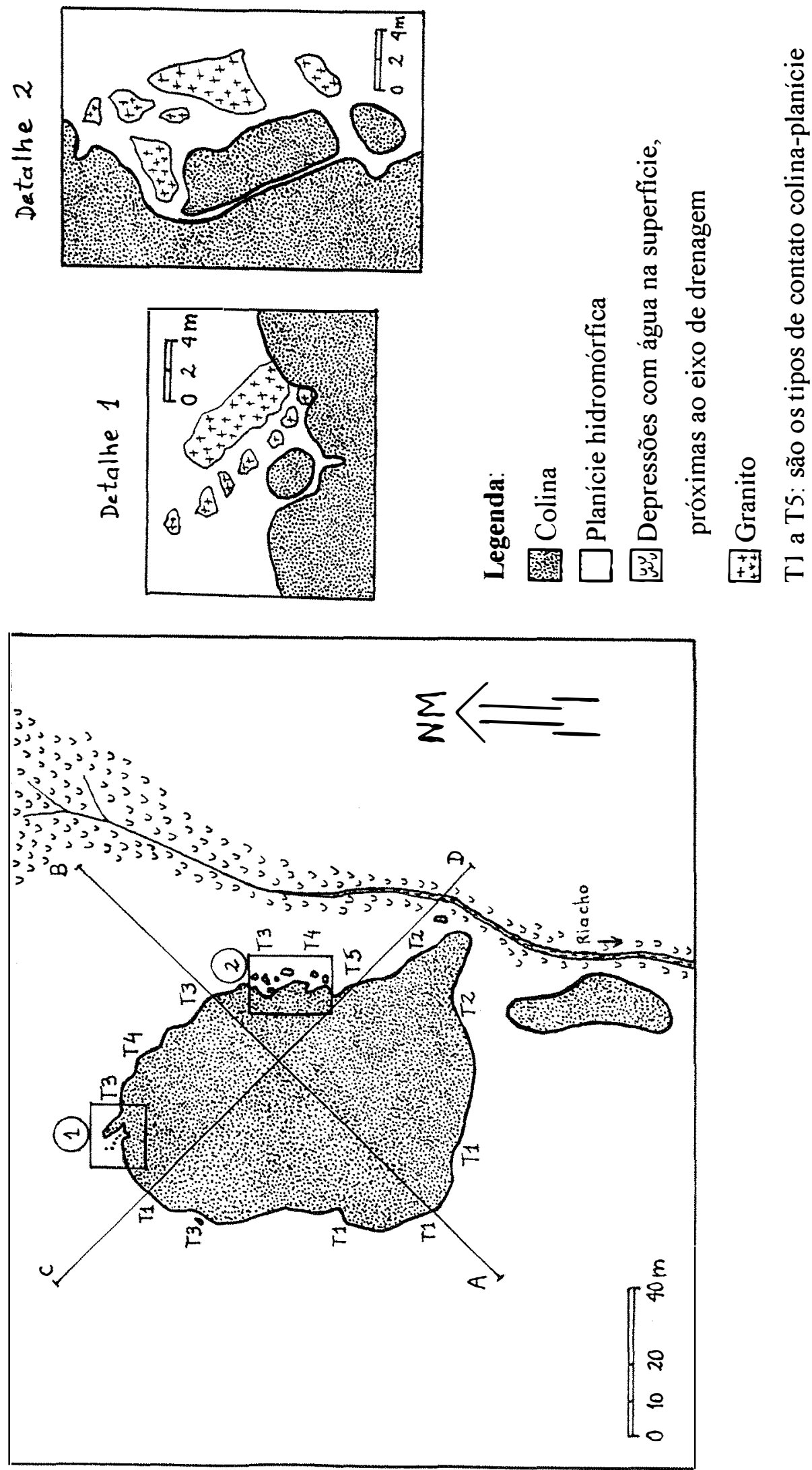
- Contato 1: (T1) o desnivel é gradual, formando um degrau com até $20 \mathrm{~cm}$ de altura. A rocha acompanha o desnivel do terreno na borda da colina, entre 5 a $15 \mathrm{~cm}$ de profundidade (Figura 5a). Em algumas porções, a rocha está exposta na superficie. Na planície a rocha aprofunda-se abruptamente a medida que se afasta da zona de contato (Figura 6a). A porção plana adjacente à colina é ligeiramente rebaixada em relação à porção mais afastada da colina. Tais depressões apresentam acúmulo de água na superficie (afloramento do lençol freático) por ocasião de chuvas intensas. O solo na zona de contato colina-planície é bruno-escuro e raso, com seqüência de horizontes A-R. - Contato 2: (T2) o desnivel é acentuado, com granito exposto (rocha sã) na borda da colina formando degraus de até $80 \mathrm{~cm}$ de altura (Figura 5b). Em direção à colina, a rocha aprofunda-se acentuadamente. $\mathrm{Na}$ parte inferior da encosta, aparecem alguns matacões na superficie. Na planície, a rocha aprofunda-se de maneira gradual a medida que se distancia da colina. A transição de solos é demarcada pela rocha (Figura 6b).

- Contato 3: (T3) o desnivel é acentuado, formando uma rampa ligeiramente convexa, com 20 a $25 \%$ de declividade. Na borda da colina a rocha sã aparece entre 1,6 e 2 m de profundidade; o limite horizontal é irregular. Em algumas porções, no início da planície hidromórfica, surgem protuberâncias rochosas com topo próximo à superfície (miniinselbergs). A transição entre os solos da colina e os do plano se dá numa faixa decamétrica (Figura 7a).

- Contato 4: (T4) o desnível é muito abrupto, a borda da colina é caracterizada pela presença de barrancos com 60 a $80 \mathrm{~cm}$ de altura. A rocha na borda da colina encontra-se sob o nivel do lençol freático, entre 1,4 e 1,8 m de profundidade. Esta zona de contato é também marcada pela presença de inúmeros afloramentos de granito em superficie, dispersos na parte plana. Tais afloramentos têm a forma de matacões ou "miniinselbergs". A superficie do solo na parte plana é bastante irregular, formando inúmeras depressões centimétricas, rasas, muitas vezes alagadas (Figura 7b).

- Contato 5: (T5) o desnivel é semelhante ao anterior, ocorrendo, na borda da colina, montículos arredondados, formados por solo amarelado e argiloso, com até $80 \mathrm{~cm}$ de altura e de 1 a $2 \mathrm{~m}$ de diâmetro (Figuras $5 \mathrm{c}$ e $5 \mathrm{~d}$ ). A zona de contato é bastante recortada e alguns desses montículos são quase que totalmente circundados pelo material da 


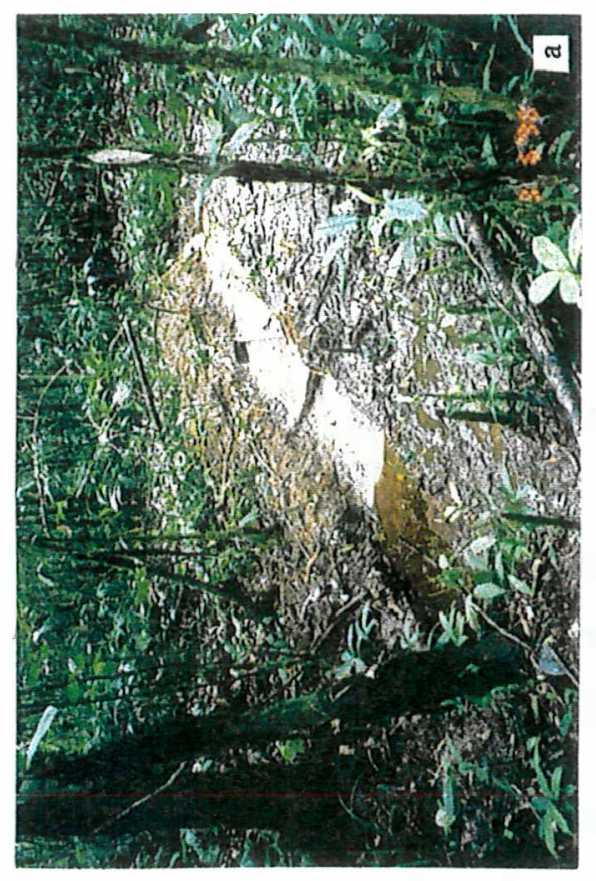

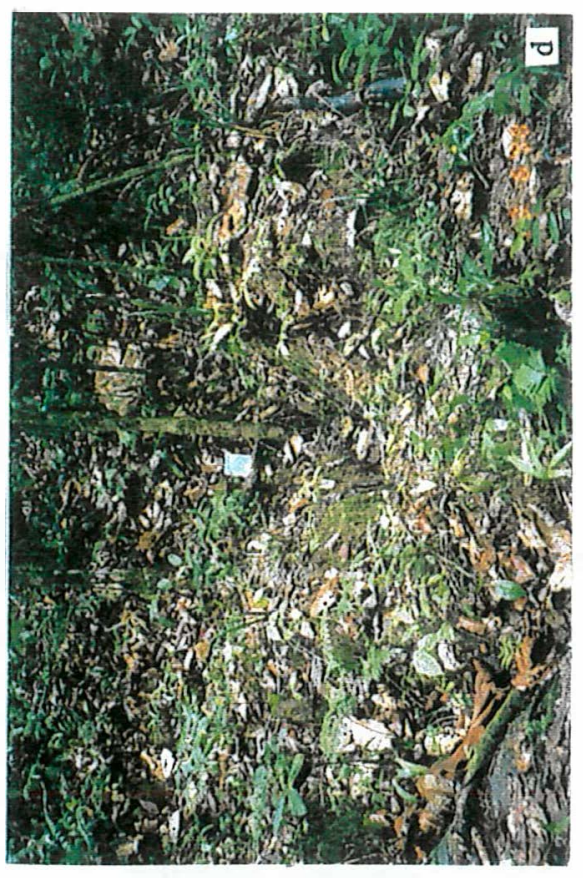
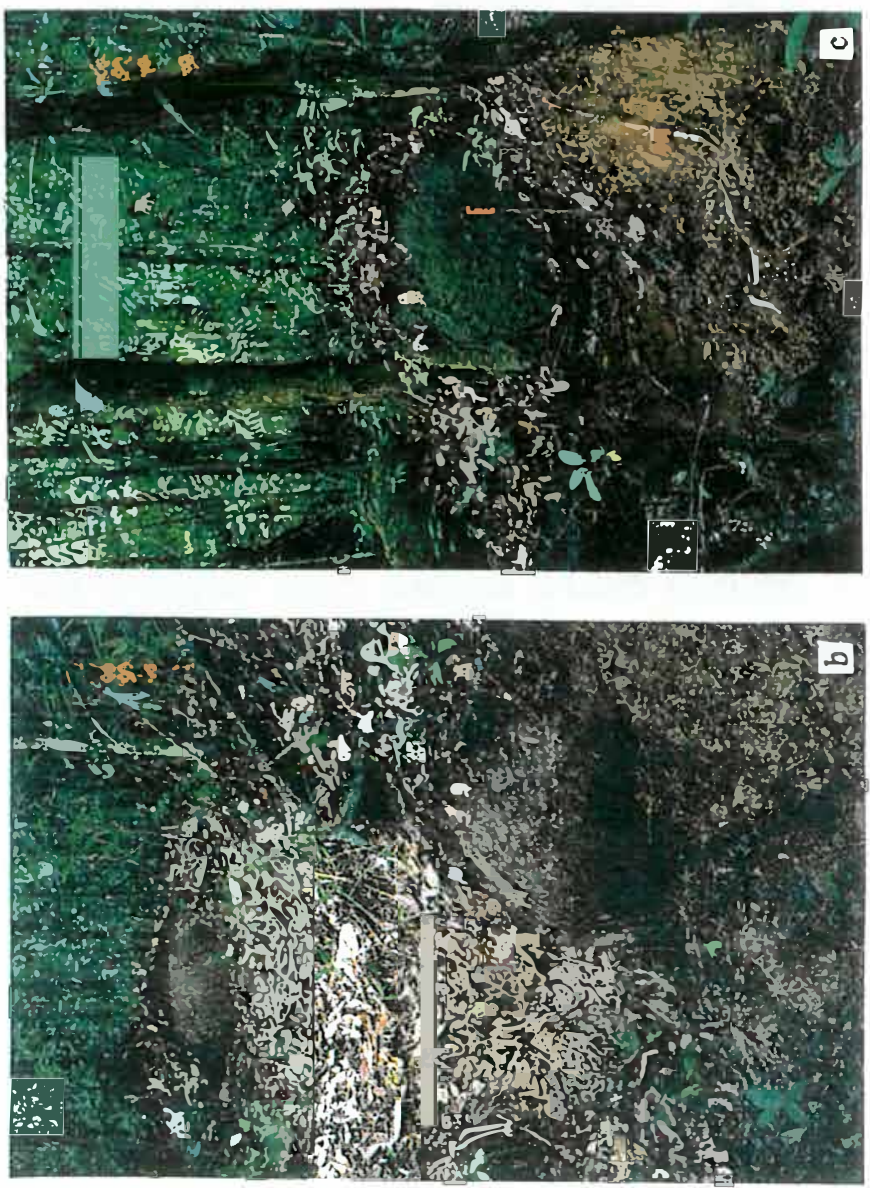

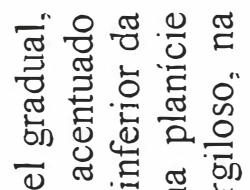

ब

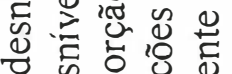

ह 웜

8ํ.

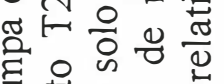

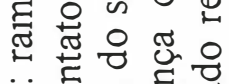

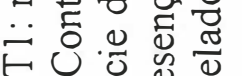

을

苟 0 ส

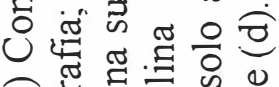

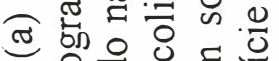

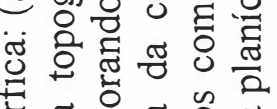

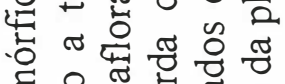

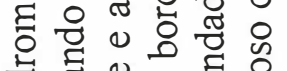

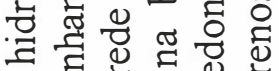

品。芯

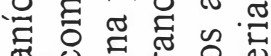

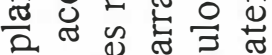

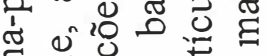

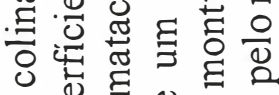

选害守 守 。

苛

0 范茞

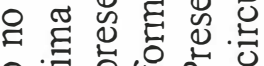

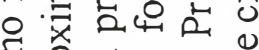

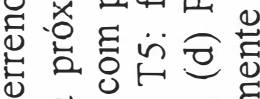

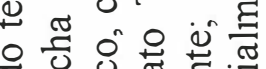

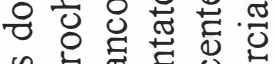

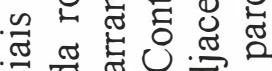

㝴

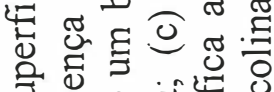

जे

吃

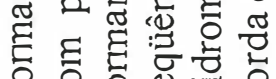

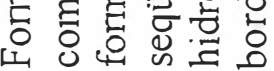

的

范

它 


\section{Legenda: volumes, horizontes e constituintes do solo (Ver ítem 4.2)}

\section{a) Colina}

Volume 1, Horizonte A: bruno-amarelado-escuro; franco-arenosa; granular

IIII Vol. 1, Hor. BA: bruno-amarelado; franco-argilo-arenosa; granular

Vol. 1, Hor. Bw: amarelo-brunado; argilo-arenosa; maciça e forte muito pequena granular

Al. Vol. 2, Hor. BC: amarelo-brunado a amarelo-avermelhado; argilo-arenosa com cascalho; maciça e forte muito pequena granular

国络 Vol. 3, Hor. C: vermelho a amarelo-brunado; franco-argilo-arenosa com cascalho e fragmentos de rocha

W.1 Concreções ferruginosas

\section{b) Planície hidromórfica}

典 Vol. 6, Hor. A: bruno-escuro; arenosa; granular

$\square$ Vol. 7, Hor. E: cinzento-brunado-claro; arenosa; grãos simples

Vol. 8, Hor. Bh endurecido: bruno-muito-escuro; arenosa; maciça

[ill Vol. 8, Hor. BhC: bruno-escuro; arenosa; maciça

[t:

猋 Vol. 10, Hor. Cg: bruno-claro-acinzentado; areia franca a franco-arenosa; maciça

Vol. 11, Hor.Cgr: bruno-escuro a oliva, manchado; franco-arenosa; maciço

Granito 

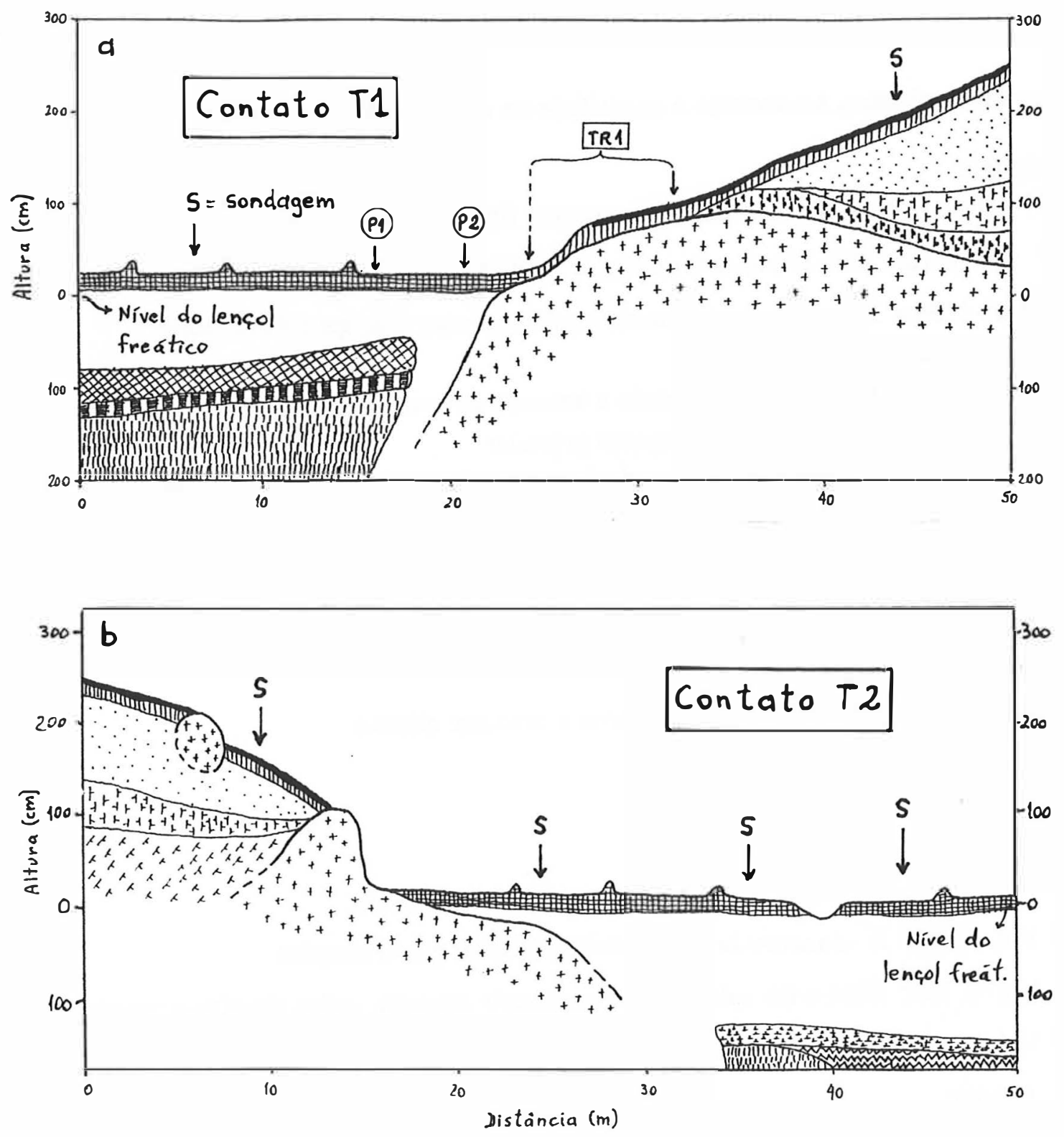

Figura 6 - Formas superficiais do terreno no contato colina-plano, com cortes laterais bidimensionais mostrando a organização dos materiais: (a) Contato T1: rampa com desnivel em degrau baixo, com presença da rocha próxima da superfície; (b) Contato T2: desnivel acentuado formando um barranco, com presença de granito na parede em afloramento na superfície do solo na porção inferior da sequeència. 
Legenda: volumes, horizontes e constituintes do solo (Ver ítem 4.2)

\section{a) Colina}

Vol. 1, Hor. A: bruno-amarelado-escuro; franco-arenosa; granular

而 Vol. 1, Hor. BA: bruno-amarelado; franco-argilo-arenosa; granular

: Vol. 1, Hor. Bw: amarelo-brunado; argilo-arenosa; maciça e forte muito pequena granular

H. Vol. 2, Hor. BC: amarelo-brunado a amarelo-avermelhado; argilo-arenosa com cascalho; maciça e forte muito pequena granular

Vol. 3, Hor. C: vermelho a amarelo-brunado; franco-argilo-arenosa com cascalho e fragmentos de rocha

$\because$ Vol. 4, Hor. BCg e CBg: oliva-claro-acinzentado com mosqueados; francoarenosa; maciça

ब.9 Vol. 4, Hor. Bi, BCg: amarelo oliváceo, franco-argilo-arenosa com nódulos gibbsíticos ; maciça

* Vol. 5, Hor. Cg: oliva, franco-arenosa a arenosa; alterita

Concreções ferruginosas

\section{b) Planície hidromórfica}

Volume 6, Horizonte A: bruno-escuro; arenosa; granular

Vol. 7, Hor. E: cinzento-brunado-claro; arenosa; grãos simples

Fol. Vol. 9, Hor. E/Bh e Bh solto: cinzento-escuro; arenosa; grãos simples e maciça

Vol. 10, Hor. Cg: bruno-claro-acinzentado; areia franca a franco-arenosa; maciça

Franito 

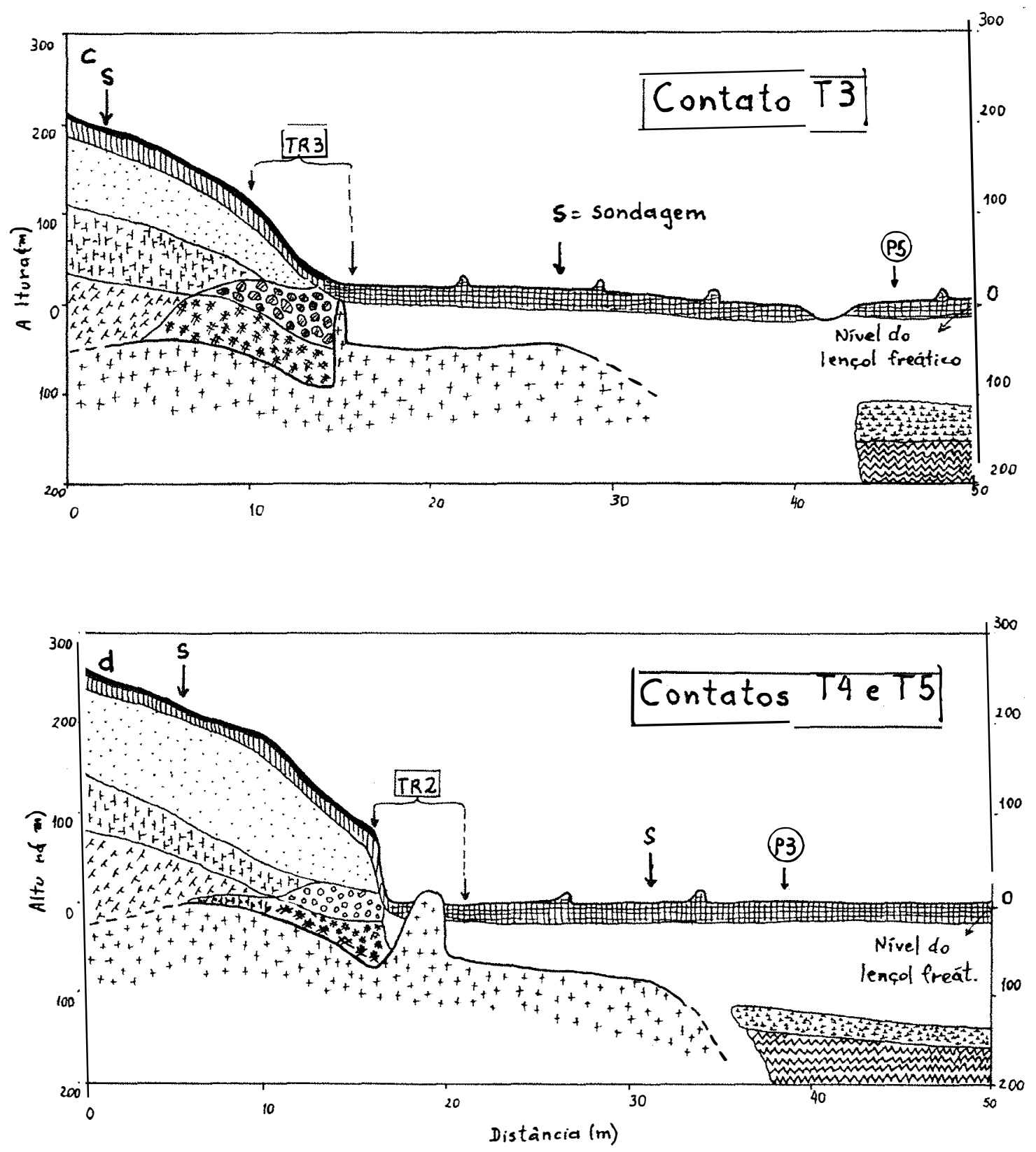

Figura 7 - Formas superficiais do terreno no contato colina-plano, com cortes laterais bidimensionais mostrando a organização dos materiais: (a) Contato T3: presença de uma rampa no contato, com rocha em subsuperficie; (b) Contatos T4 e T5: presença de um barranco na borda da colina e afloramento da rocha na planicie adjacente (mini-inselberg"submerso na areia). 
planície (relíquias de parte da colina). Os matacões de granito na superfície são menos abundantes em relação ao tipo anterior. Depressões centimétricas, rasas, são comuns nesta zona de contato.

- Distribuição dos tipos de contato colina-planície

A distribuição dos tipos de contato colina-planície pode ser relacionada com a declividade das vertentes e com a forma dos contornos na zona de contato. $\mathrm{O}$ contato Tl ocorre nas porções oeste e sudoeste da colina, em vertentes mais longas, onde o terreno tem menor declividade e os contornos na zona de contato são pouco recortados (Figura 4). O contato T2 limita-se a uma seção da colina com formato alongado, que tangencia o eixo de drenagem. Este contato localiza-se nas proximidades de uma porção rebaixada da colina, totalmente circundada pela planície hidromórfica. $\mathrm{O}$ contato T3 ocorre numa porção da colina com vertente curta e de maior declividade. Os contatos T4 e T5 localizam-se nas faces nordeste e leste da colina, em vertentes curtas, mais declivosas e com contornos intensamente recortados.

A distribuição dos tipos de contato colina-planície parece estar relacionada, também, com variações litológicas, que eventualmente influenciam o intemperismo e a formação dos solos nestas áreas. Nos contatos T1 e T2 o granito é cinzento-claro, com cristais de 1 a $3 \mathrm{~mm}$ de diâmetro. $\mathrm{O}$ teor de quartzo é relativamente alto e as fraturas são pouco freqüentes. Estas evidências indicam uma maior resistência de tal fácies de granito ao intemperismo, o que poderia, ainda, explicar sua maior proximidade à superficie, bem como, sua presença sempre acima do lençol freático. Nos demais tipos de contato, o granito é mais escuro e os matacões ou afloramentos presentes na superficie têm estrutura porfiritica. Este fácies aparece abaixo do nivel do lençol freático e apresenta maior fraturamento. Nestas porções evidenciam-se contornos de colina mais intensamente recortados.

Outra feição superficial do terreno, muito comum na região e observada na área de estudo, na zona de contato colina-planície é o rebaixamento do terreno na borda da colina, formando uma depressão fechada, identificada na extremidade do alinhamento nordeste (ver localização na Figura 3). Esta depressão localiza-se a $2 \mathrm{~m}$ da 
zona de contato da colina-planície, tem $5 \mathrm{~m}$ de comprimento, até $2 \mathrm{~m}$ de largura e 70 a $80 \mathrm{~cm}$ de profundidade (Figuras $8 \mathrm{a}$ e $8 \mathrm{~b}$ ). O formato é amebóide, de contorno digitado ou circular. O solo nas paredes é bruno-amarelado, argiloso, passando para areia com cascalho e material orgânico na base. Após chuvas intensas constatou-se água livre no fundo da depressão. Tal feição superficial foi observada por diversas vezes em áreas com predominância de latossolos, ao longo da BR307. Particularmente, no km 75 desta rodovia, as depressões são abundantes e, têm de 2 a $5 \mathrm{~m}$ de diâmetro, e até $1 \mathrm{~m}$ de profundidade.

c) Planície hidromórfica

A planície hidromórfica ocupa a maior parte da área nas seqüências estudadas. A superficie do solo tem aspecto muito irregular (microrrelevo), decorrente da presença de inúmeros montículos cônico-arredondados, de até $30 \mathrm{~cm}$ de altura. Estas estruturas são constituídas de dejeções organominerais de minhocas. Ocorrem, ainda, dispersos nessa planície, vários matacões de granito nas proximidades do contato com a colina (Figura 8c).

Os solos presentes nessa área são muito arenosos. O lençol freático situase entre 10 e $20 \mathrm{~cm}$ de profundidade, podendo aflorar em alguns locais, especialmente, nas proximidades do eixo de drenagem. Nesta porção do terreno ocorrem inúmeras depressões alagadas, centimétricas, com 10 a $20 \mathrm{~cm}$ de profundidade. A medida que se aproxima do eixo de drenagem essas depressões tornam-se mais abundantes e interligadas. A água circula entre elas lentamente, muitas vezes passando sob uma camada superficial de raízes. O eixo de drenagem é formado por um curso d'água com 1 a $2 \mathrm{~m}$ de largura, localizado a leste da colina estudada, apresentando fluxo para o sul (Figura 8d). A água presente nos solos do plano tem coloração bruno-amarelada, em função da presença de matéria orgânica dissolvida. Na abertura das trincheiras notou-se que a água adquiria coloração bruno-escura devido a presença de grande quantidade de material em suspensão. Cessada a mobilização, a decantação da suspensão ocorria após alguns minutos e a água readquiria uma coloração bruno-amarelada. 

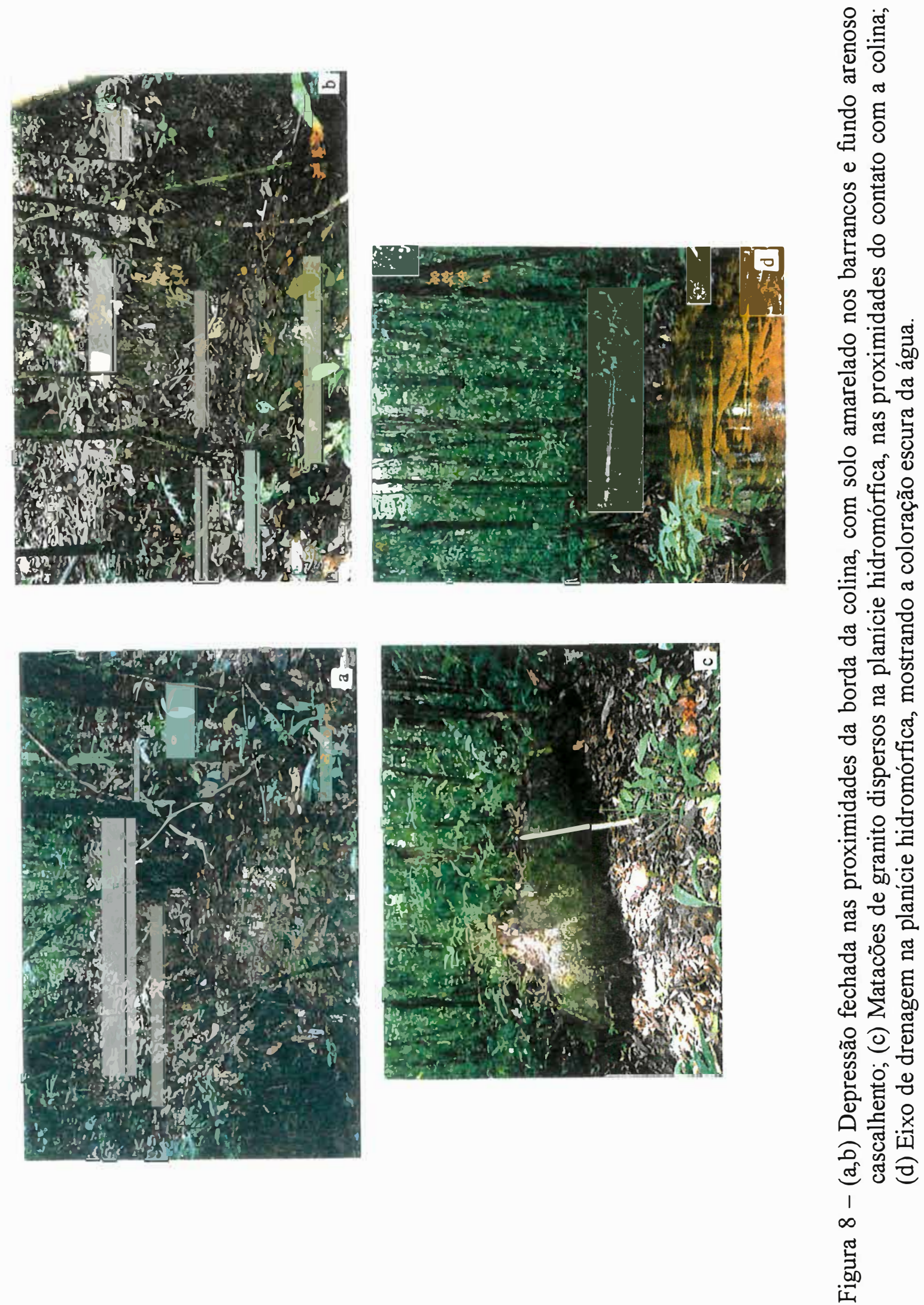
A vegetação da área plana é do tipo campinarana, caracterizada pelo predomínio de árvores finas, com 10 a $30 \mathrm{~cm}$ de diâmetro, apresentando-se mais aberta, pela presença de sub-bosque menos denso que aquele encontrado na colina. A altura das árvores é de cerca de 20 metros. Próximo às cabeceiras do eixo de drenagem, observamse alguns agrupamentos de palmeiras.

\subsection{Organização da cobertura pedológica}

As seqüências estudadas compõem um sistema pedológico, de um lado ocorrem solos argilo-arenosos a argilosos presentes numa colina baixa e, do outro, solos arenosos, presentes numa extensa planície hidromórfica. A caracterização macromorfológica dos solos, efetuada em dois alinhamentos transversais entre si, desde a colina até a porção aplainada, evidencia variações verticais e laterais nesse sistema, as quais foram descritas detalhadamente na zona de contato (Figura 9). Os diferentes materiais com relação a cor, textura, constituição, estrutura e porosidade foram ordenados em onze volumes pedológicos distintos.

A morfologia dos solos foi descrita em sete trincheiras. Na colina foram descritos dois perfis, um no topo (C1) e outro em meia encosta (C2), formados por solos amarelados friáveis. Na borda da colina foram abertas três trincheiras (TR1, TR2 e TR3). Estas abrangiam o material arenoso sobre a rocha na planície hidromórfica, até o perfil de solo amarelado na borda da colina. Na planície hidromórfica foram caracterizados três perfis, sendo dois compostos por solos com presença de horizonte $\mathrm{Bh}$ (P1 e P3) e outro por um solo com presença de areia branca sobre a rocha (P2).

- $\underline{\text { Colina }}$

As descrições morfológicas detalhadas estão presentes nos anexos A (macromorfologia) e B (meso e micromorfologia). A seguir serão apresentadas as principais organizações dos materiais presentes na colina, partindo-se da superficie para base dos perfis e de montante para jusante nas seqüências. 

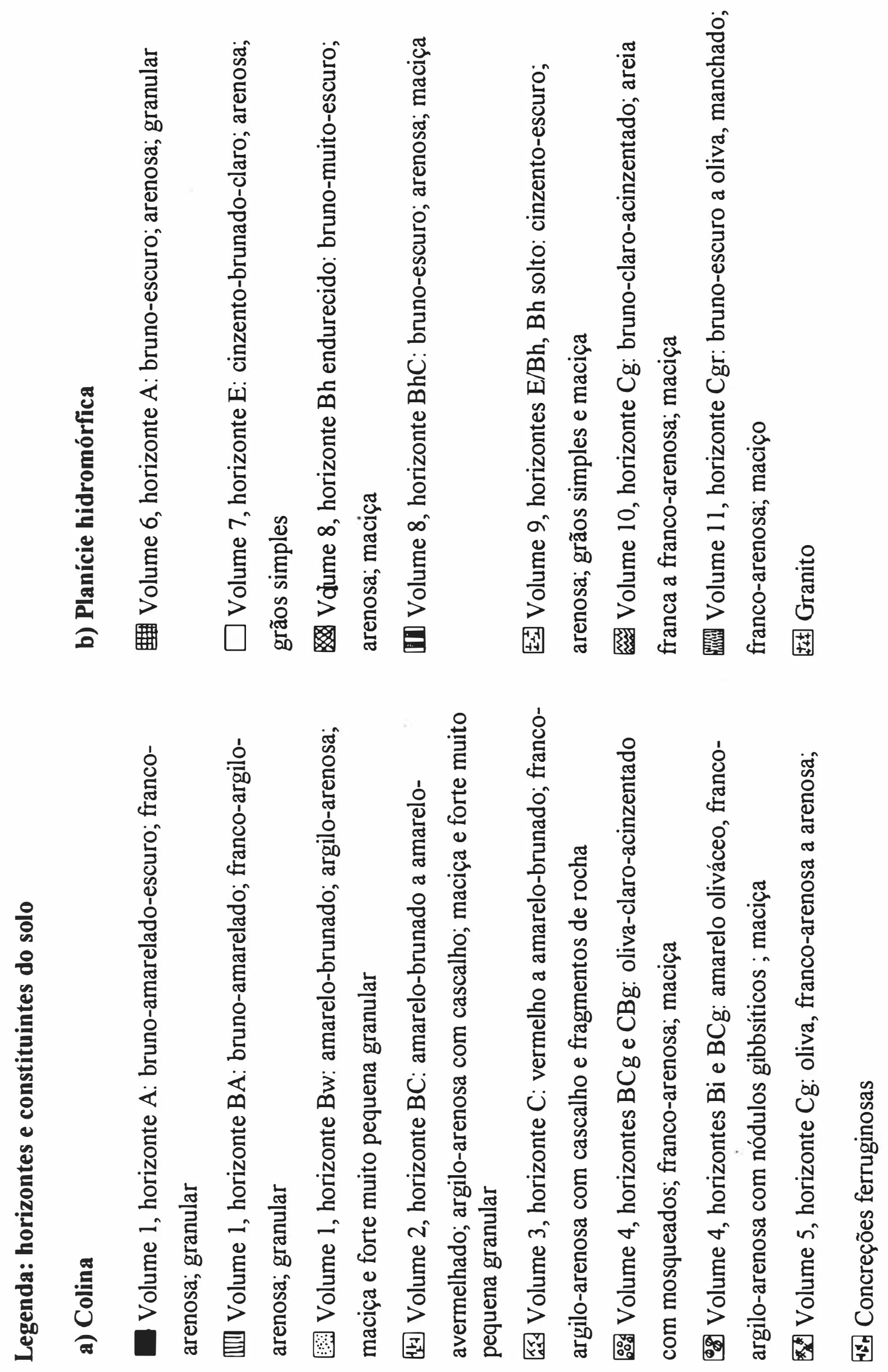


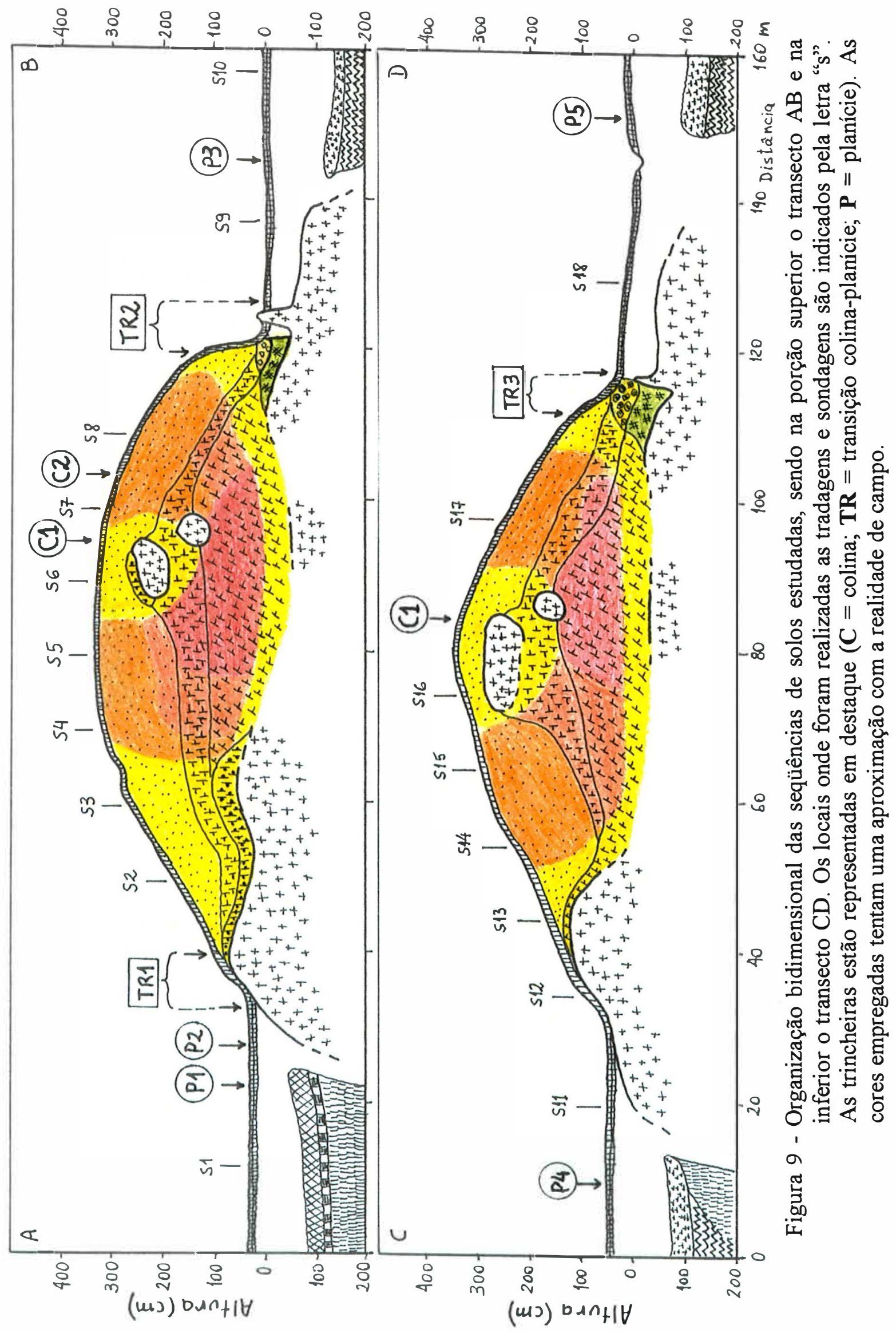


A organização vertical dos solos na colina é caracterizada por um conjunto latossólico (Horizonte $\mathrm{Bw}$ ), disposto acima de um conjunto intermediário (Horizonte $\mathrm{BC}$ ou $\mathrm{CB}$ ), que recobre uma alterita de granito (Horizonte $\mathrm{C}$ ) pouco profunda (até 2 metros). A diferenciação dos materiais quanto a cor, estrutura e quantidade de minerais primários alteráveis é gradual entre os diferentes conjuntos, evidenciando uma diferenciação pedogenética progressiva a partir do material de origem.

A distribuição lateral dos conjuntos pedológicos na colina evidencia uma disposição simétrica, salientando-se a redução em espessura do material latossólico nas proximidades da borda da colina, com gradual amarelecimento e gleização subsuperficial dos solos. Este amarelecimento pode ser relacionado a condições de maior acúmulo de água, verificado nas proximidades do lençol freático no topo da colina e na parte inferior das vertentes. $\mathrm{O}$ amarelecimento progride na borda da colina para um material mosqueado sobre uma alterita acinzentada, presente em meio permanentemente alagado. À medida que o material vai se tornando acinzentado, a textura também muda, tornando-se gradualmente arenosa, passando da alterita acinzentada para as areias brancas do plano hidromórfico adjacente.

Os volumes ou conjuntos pedológicos na colina são os seguintes:

- Volume 1: conjunto latossólico, horizontes A e Bw. Na superficie (Horizonte A), o material é mais escuro, a estrutura é grumosa e granular, com agregados de 1 a $3 \mathrm{~mm}$ (Figura 10a). Abaixo desta camada, o material tem estrutura composta por domínios mais adensados, com distribuição relativa porfirogrânica (o plasma envolve totalmente os grãos do esqueleto) e dominios mais porosos, microagregados, eunálicos (Figura 10b). No exame macromorfológico estes dominios apresentam estrutura forte muito pequena granular (Horizonte $\mathrm{Bw}$ ). O plasma dos microagregados é semelhante (cor, anisotropia) aos dominios adensados. Os microagregados aparecem ora em pedotúbulos, ora dispersos no fundo matricial, formando uma rede com os dominios adensados. Neste último caso, os limites entre tais dominios estruturais são difusos. Nas bordas da colina, o solo tem espessura reduzida e coloração amarela (10YR 6/8), tornando-se bruno-forte (7.5YR 5/8) e mais espesso ( 1 a $1,5 \mathrm{~m}$ ) em meia encosta. No topo da colina é amarelado 
(10YR 6/8), pouco espesso $(0,6$ a $1 \mathrm{~m})$ e com presença subsuperficial de matacões de granito, isolados no contato dos horizontes $\mathrm{Bw}$ e $\mathrm{BC}$ (também no contato $\mathrm{BC}$ e $\mathrm{C}$ ). $\mathrm{O}$ plasma é relativamente homogêneo, com fraca anisotropia, evidenciando uma estrutura plásmica argilassépica a insépica.

- Volume 2: conjunto intermediário, horizonte BC. Este conjunto apresenta maior quantidade de litorrelíquias (feldspatos e micas). $\mathrm{O}$ aspecto é maciço, com alguns dominios com estrutura forte muito pequena granular, especialmente em pedotúbulos. A organização estrutural tem relação com o conjunto latossólico superior, com aumento progressivo em profundidade dos domínios maciços em relação aos granulares. No topo da colina esse material é amarelado (10YR 6/8) e mais espesso (até $130 \mathrm{~cm}$ ), tornandose bruno-forte (7.5YR 5/8) em meia encosta. Na borda da colina esse conjunto torna-se gradativamente amarelado e pouco espesso $(<60 \mathrm{~cm})$.

- Volume 3: alterita de granito (Horizonte C), com abundância de feldspatos e micas (Figura 10c). A estrutura é herdada da rocha, com domínios formados por agregados granulares muito pequenos, pouco abundantes, com aspecto semelhante ao fundo matricial adjacente, muitas vezes associados a pedotúbulos. As variações na estrutura, cor e quantidade de minerais primários decomponiveis são gradativas em relação ao conjunto sobrejacente. O plasma apresenta maior anisotropia, a estrutura plásmica é silassépica a latissépica. A alterita é espessa e avermelhada na porção superior das vertentes, apresentando microdomínios amarelados (Figura 10d). Em profundidade, próximo ao nivel do lençol freático e, em direção as partes inferiores das vertentes, o material torna-se amarelado e menos espesso. Concreções e nódulos ferruginosos ocorrem na camada logo acima da rocha em algumas porções próximas às bordas da colina, em maior quantidade na parte sudoeste da colina, onde a base granítica apresenta um limite regular, contínuo e próximo à superficie.

- Volume 4: conjunto mosqueado, subsuperficial (Horizontes $\mathrm{BCg}$ e $\mathrm{CBg}$ ), com ocorrência localizada na borda da colina (zona de contato com a planície hidromórfica), somente em vertentes mais curtas e declivosas, disposto abaixo do conjunto latossólico amarelado. Esse conjunto encontra-se em contato com as águas escuras que ocorrem na planície hidromórfica (Figura 11a); apresenta manchas vermelho-amareladas, formando 

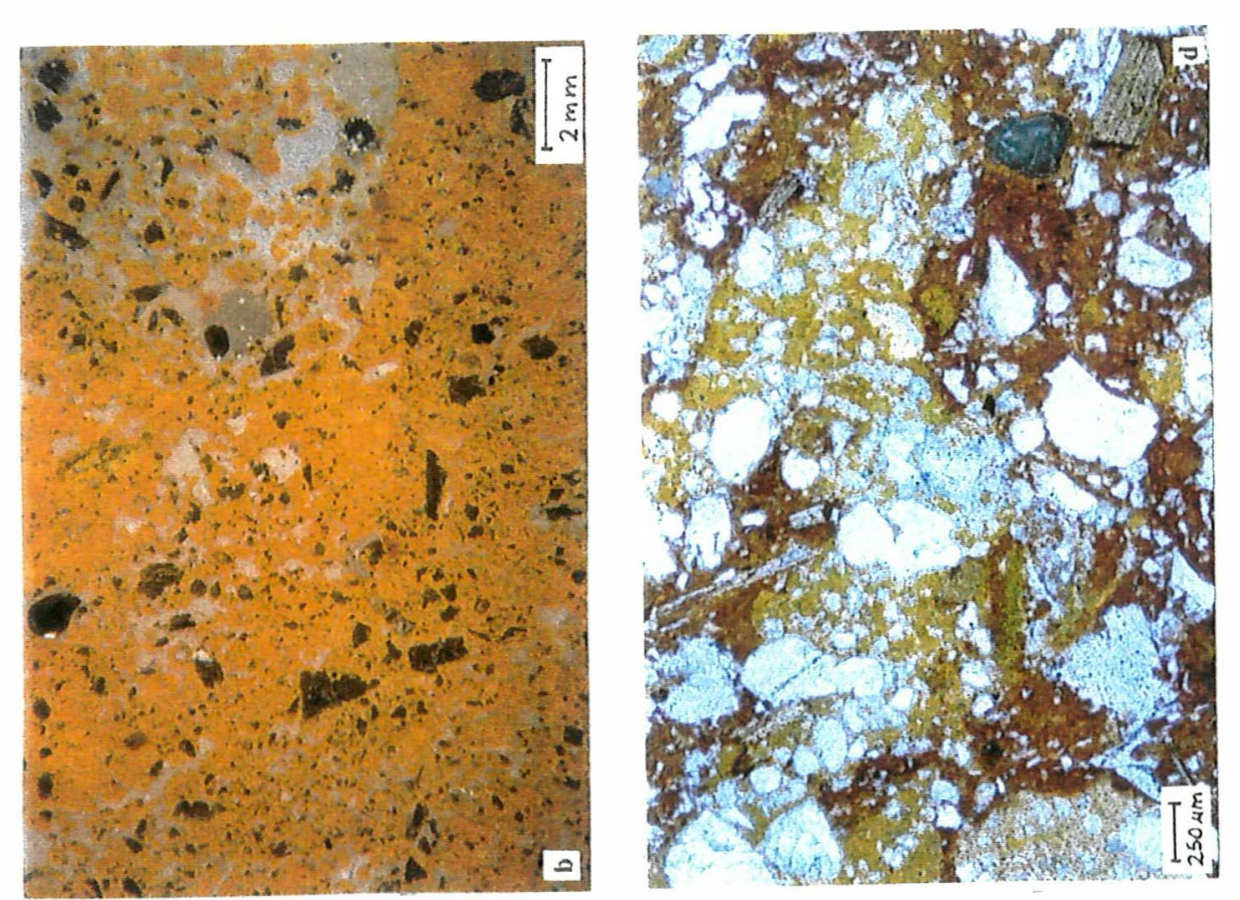

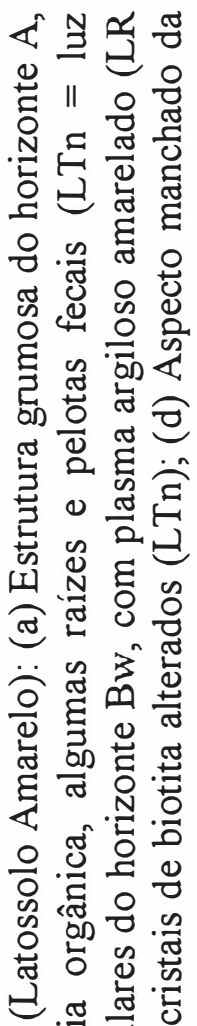
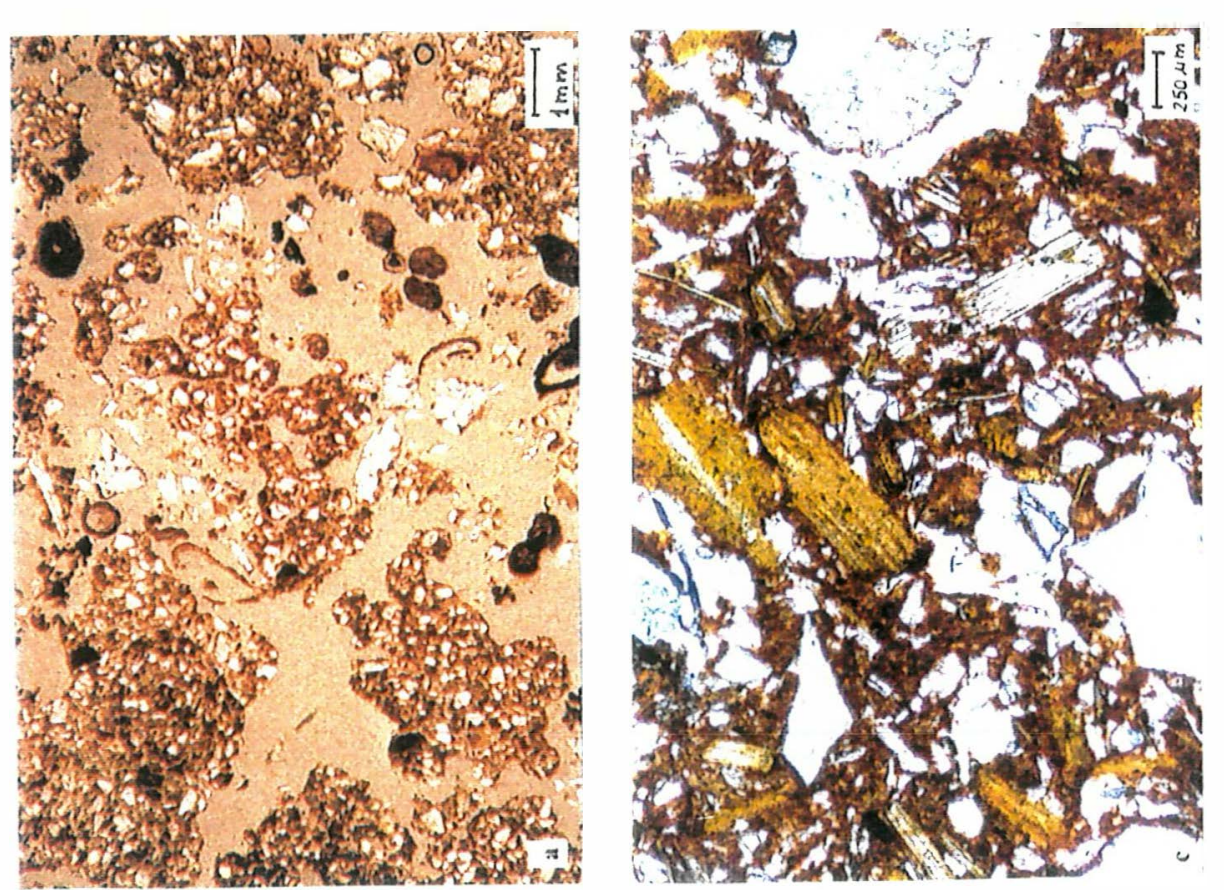

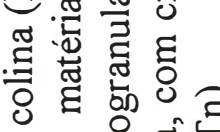
ช

운유 ป क. ․ㅠㅇㅇㅝ

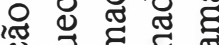

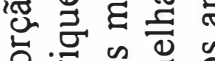
ถั ชั \& 융 छ

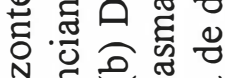
줄 웡 宁 क 0 与 ชீ สี่ 焉 空吕㤩

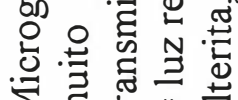



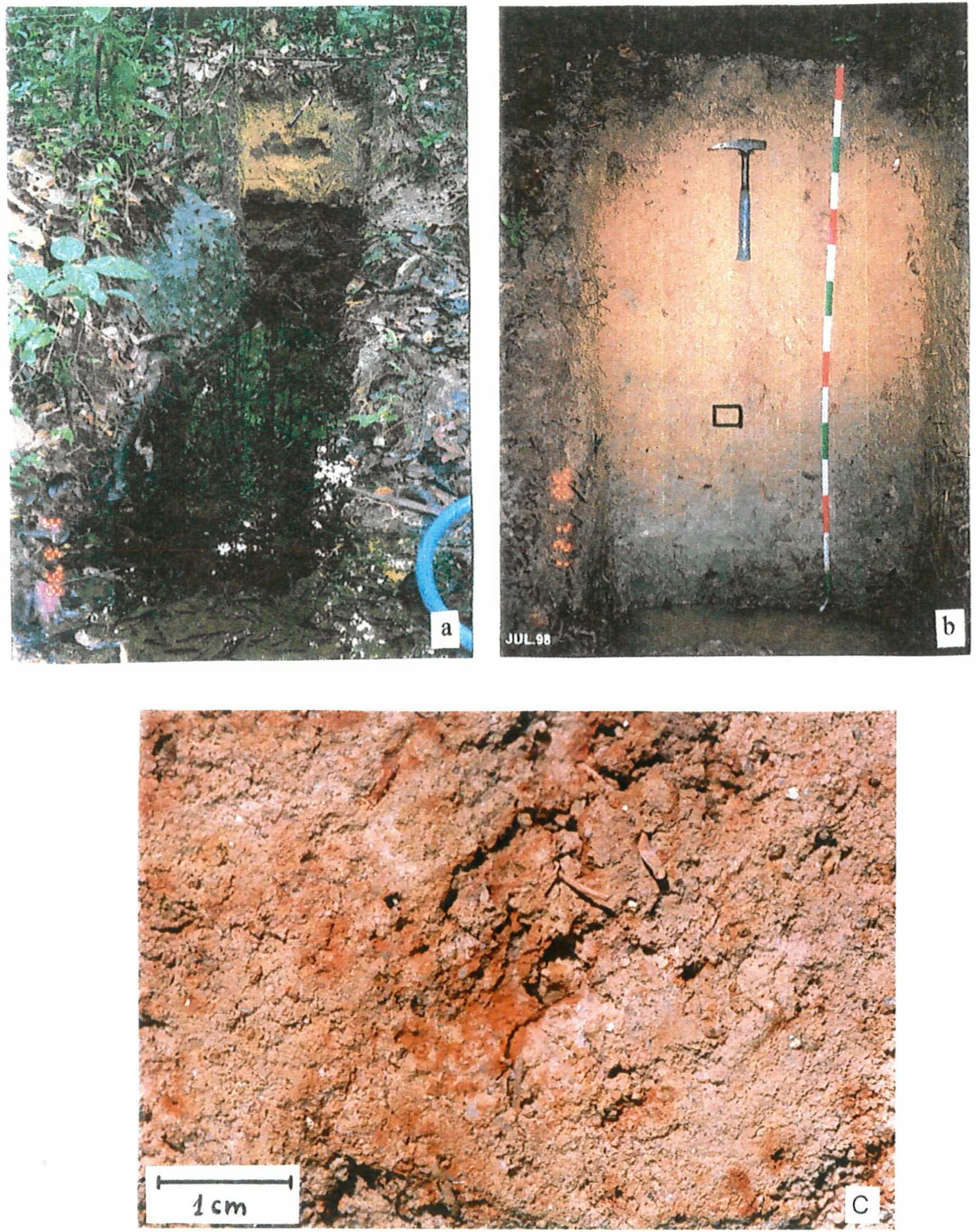

Figura 11 - Ilustrações da zona de contato colina-planície, trincheira TR2: (a) Presença de água escura em contato com o barranco na borda da colina. Na parte plana pode-se identificar um matacão de granito no lado esquerdo da foto; (b) Perfil de sólo no barranco na borda da colina, com presença do conjunto superior latossólico, um conjunto intermediário mosqueado e a alterita acinzentada hidromórfica na base e (c) Detalhe dos mosqueados (foto $1 \mathrm{lb}$ ). 
mosqueados na porção superior, indicando migração e reprecipitação de óxidos de ferro conseqüente à flutuação do lençol freático (Figuras $11 \mathrm{~b}$ e 11c). Essas manchas foram observadas com maior detalhe em lâminas delgadas (Figura 12a). O material manchado tem ligação lateral com o conjunto intermediário em direção à porção superior das vertentes. $\mathrm{O}$ aspecto macromorfológico é maciço.

- Volume 5: conjunto acinzentado (alterita hidromórfica), horizonte $\mathrm{Cg}$ : disposto abaixo do material mosqueado, que torna-se progressivamente acinzentado e nitidamente mais arenoso, à medida que imperam as condições de hidromorfia. Os domínios acinzentados aparecem de forma difusa no material manchado, tornando-se gradativamente mais abundantes em direção à base, até formar uma matriz acinzentada, desprovida de mosqueados. A disposição lateral do material acinzentado em relação a porção mosqueada é ondulada (com variação de espessura em diferentes porções da trincheira), o que sugere variação da profundidade da rocha subjacente.

\section{- Diferenciação morfológica vertical nos solos na borda da colina}

A variação vertical da granulometria do solo é nítida no exame microscópico, com passagem progressiva de uma distribuição relativa porfirogrânica no material latossólico, para uma distribuição intertéxtica e aglomeroplásmica em profundidade. Esta perda de argila no conjunto mosqueado (Horizontes $\mathrm{BCg}$ ou $\mathrm{CBg}$ ) pode ser constatada a partir da presença de microdomínios com areia lavada na altura do lençol freático (Figura 12b), progredindo até um material arenoso presente na alterita acinzentada (Figura 12c). Na parte inferior deste conjunto, no perfil TR2/I, foram observados nódulos de natureza ferruginosa. No outro perfil, em TR3/I, os nódulos são constituídos por macrocristais de gibbsita (Figura 12d), mais ou menos ferruginizados.

\section{- Variações laterais dos solos no contato colina-planície hidromórfica}

A caracterização detalhada dos solos na zona de contato colina-planície hidromórfica revelou a ocorrência de uma transição abrupta entre os solos, que ocorre numa distância de 1 a $5 \mathrm{~m}$ e num desnivel inferior a $1 \mathrm{~m}$. Os resultados da descrição macromorfológica dos solos e a localização das amostragens estão presentes no Anexo A, sendo complementada pela descrição micromorfológica (Anexo B). 

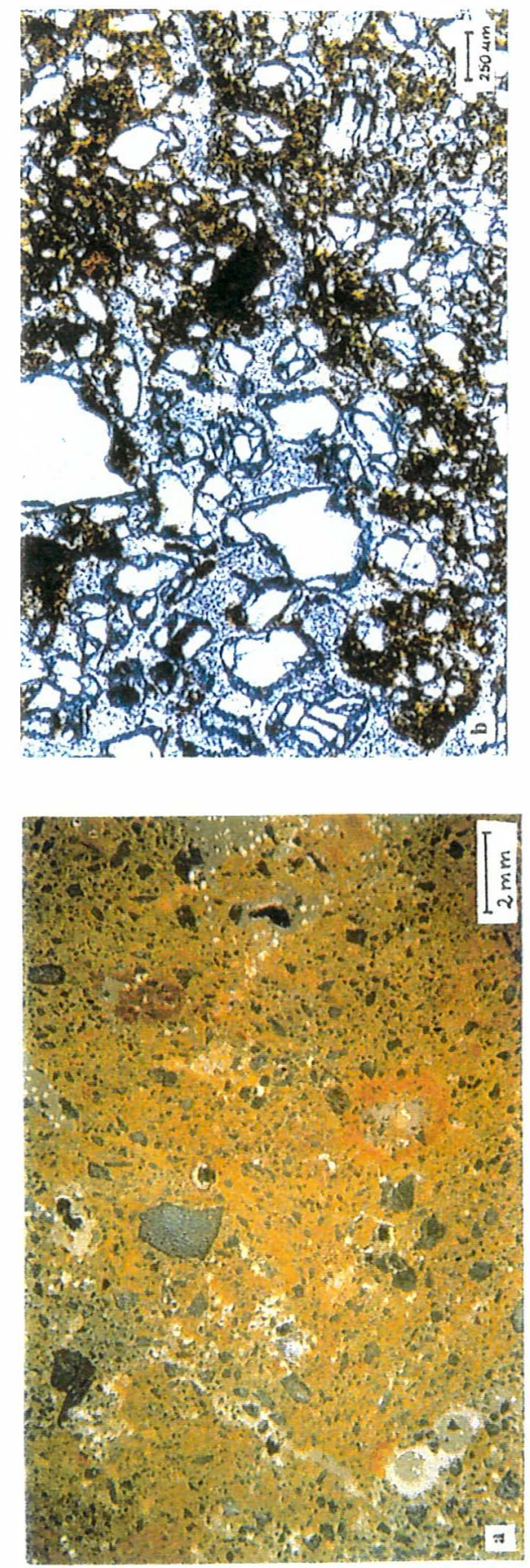
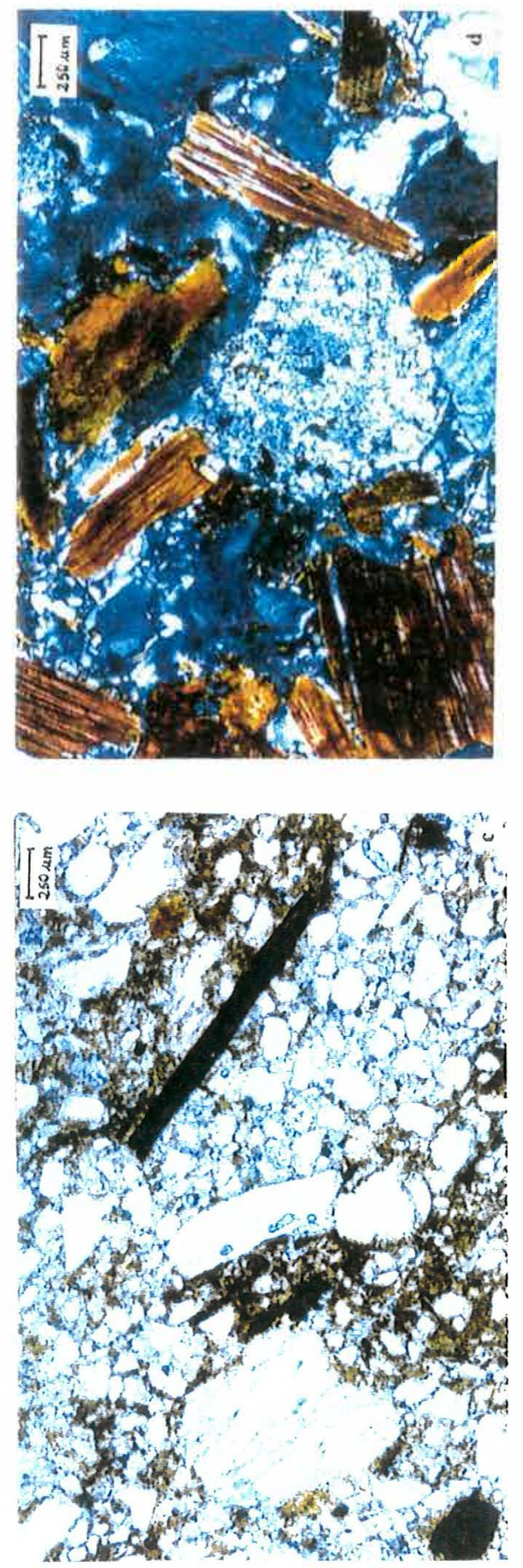

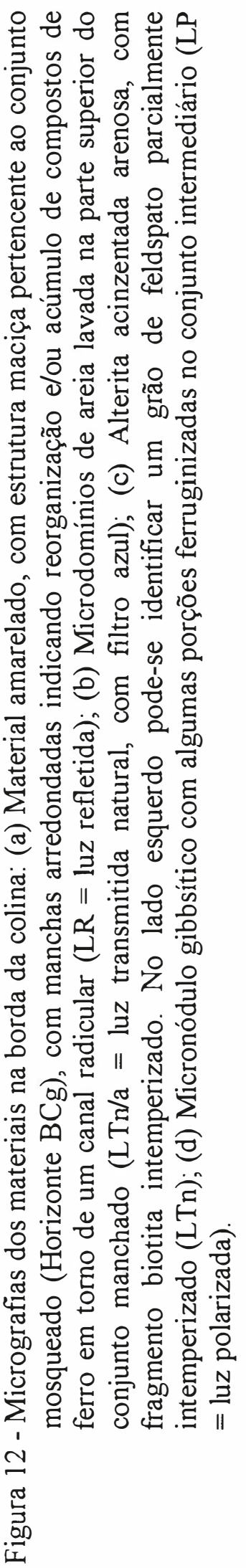


A rocha encontra-se próximo a superficie ou aflorando nos contatos colina-planície T1 e T2, estabelecendo a ligação entre a colina e a planície hidromórfica e constituindo-se o limite entre os solos. Nas outras situações (T3, T4 e T5), localizadas nas porções com os contornos mais recortados e relacionadas com a presença do conjunto mosqueado e do gleizado na borda da colina, verifica-se, na porção superior dos solos, uma redução na espessura do volume latossólico próximo a borda da colina. Em direção à planície, em subsuperficie, o material acinzentado diferencia-se lateralmente e progressivamente em areia branca (Figuras 7 e 9), observando-se acúmulo de cascalho entre os matacões de granito. O contato T3 apresenta uma situação intermediária, formando uma rampa com declive menos acentuado e com presença de material relativamente argiloso com estrutura maciça sobre uma alterita acinzentada, compondo uma zona de transição com aproximadamente 4 metros de largura no início do plano. Nos contatos T4 e T5, a rocha é mais profunda e as variações laterais na coloração, passando de amarelo na colina, para acinzentado na planície e, a perda progressiva de argila no mesmo sentido, são coincidentes com as mudanças verticais observadas entre o conjunto latossólico superior e a alterita gleizada.

\section{- Planície hidromórfica}

$\mathrm{Na}$ planície hidromórfica foram identificados seis volumes pedológicos distintos. A descrição macromorfológica desses solos foi realizada detalhadamente em três perfis (Anexo A). A caracterização micromorfológica auxiliou na identificação da organização dos constituintes minerais e orgânicos aí presentes (Anexo B).

A camada superficial desses solos é bruno-escura, com constituição organomineral, identificada como volume 6 (Figura 13a). Abaixo desta, ocorre um conjunto de areia branca, identificado como volume 7 e, sob ele, materiais escuros e enriquecidos em matéria orgânica, formando os volumes 8 e 9 (Figuras 13b e 13c). Em subsuperficie, verifica-se um conjunto cinzento-claro relativamente argiloso, chamado de volume 10 e a presença do saprolito de granito, que constitui o volume 11. As principais caracteristicas dos volumes pedológicos da planície hidromórfica são as seguintes: 
- Volume 6: conjunto organomineral, superficial (Horizonte A), pouco espesso $(20 \mathrm{~cm})$, bruno-escuro a bruno-muito-escuro, com estrutura granular. A superficie exibe microrrelevo, com montículos formados pelas minhocas (Figura 13a). Este volume apresenta uma quantidade muito grande de raízes. $\mathrm{O}$ nível do lençol freático permanece nesta camada, normalmente entre 10 a $20 \mathrm{~cm}$ de profundidade. $\mathrm{O}$ material presente nos montículos de minhoca (Figura 14a) e nas porções adjacentes (Figura 14b) é enriquecido em matéria orgânica na forma de fragmentos vegetais que conservam a estrutura e por um plasma orgânico mais humificado presente entre o esqueleto. A estrutura plásmica é isotrópica.

- Volume 7: conjunto eluvial, horizonte E, constituído por areia branca, com grãos de quartzo com granulometria heterogênea e formato anguloso a subanguloso. Nas proximidades do contato com a colina, este volume é pouco espesso, com cerca de 50 $\mathrm{cm}$ de profundidade, disposto diretamente sobre a rocha, numa faixa de 10 a $20 \mathrm{~m}$ de largura em torno da colina. A medida que se distancia da colina, observa-se um aprofundamento da rocha. Nas porções mais afastadas da colina, a cerca de $75 \mathrm{~m}$ da sua borda, o conjunto eluvial tem em torno de $1 \mathrm{~m}$ de espessura, sendo seguido em profundidade pelos volumes 8 e 9 (horizonte $\mathrm{Bh}$ ).

- Volume 8: conjunto bruno-escuro a bruno-muito-escuro, subsuperficial, arenoso, com estrutura maciça e consistência dura (Horizonte Bh endurecido). Esse conjunto é enriquecido em matéria orgânica, sendo relativamente cimentado na parte superior. A matéria orgânica compõem-se de fragmentos de raizes, com parte da estrutura vegetal conservada e, de um plasma escuro e fino, mais humificado, que se distribui entre o esqueleto, ocupando preferencialmente canais e microdomínios (Figura 14c). No topo deste volume foram encontradas litorrelíquias centimétricas, com preenchimento de material orgânico em fissuras intraminerais (Figura 14d). Esse horizonte Bh endurecido é encontrado na porção sudoeste e oeste da colina, podendo ser relacionado com a presença subsuperficial de um granito cinzento claro, pouco fragmentado (Figura 15). Esse conjunto inicia a cerca de $10 \mathrm{~m}$ da borda da colina e está disposto sobre a alterita. - Volume 9: conjunto cinzento-escuro a bruno-acinzentado-muito-escuro, subsuperficial, arenoso, com consistência solta (Horizonte $\mathrm{Bh}$ solto) e enriquecimento em matéria 

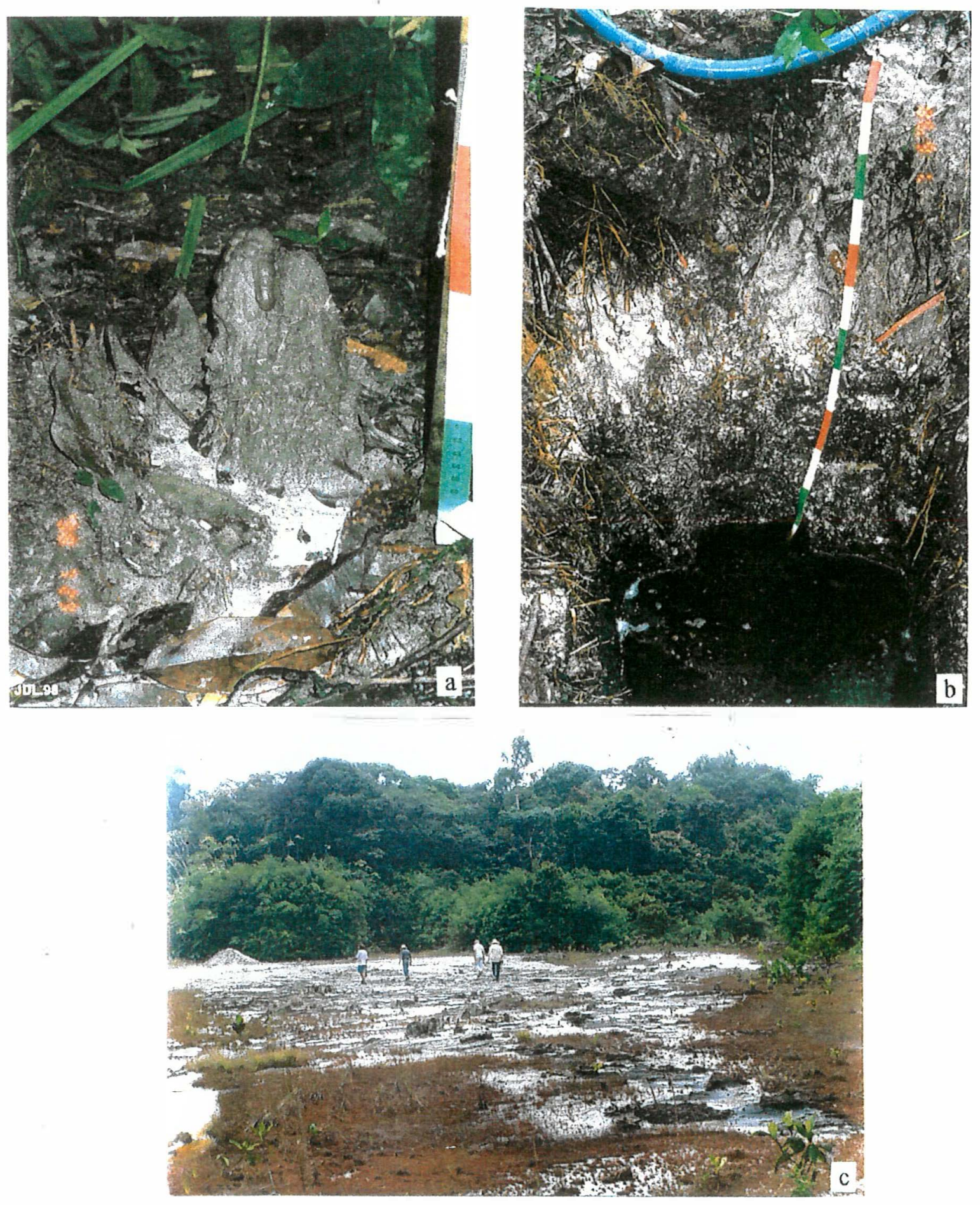

Figura 13 - (a) Conjunto superficial organomineral nos solos da planície hidromórfica (Volume 6) com presença dos montículos formados pelas minhocas; (b) Distribuição vertical dos conjuntos nesses solos, com conjunto organomineral superior, com densa ocupação por raízes, seguido pelo conjunto eluvial (Volume 7) e o Bh endurecido em profundidade (Volume 8); (c) Área de retirada de areia nas proximidades de Cucuí (BR 307, km 182), com horizonte Bh exposto. 

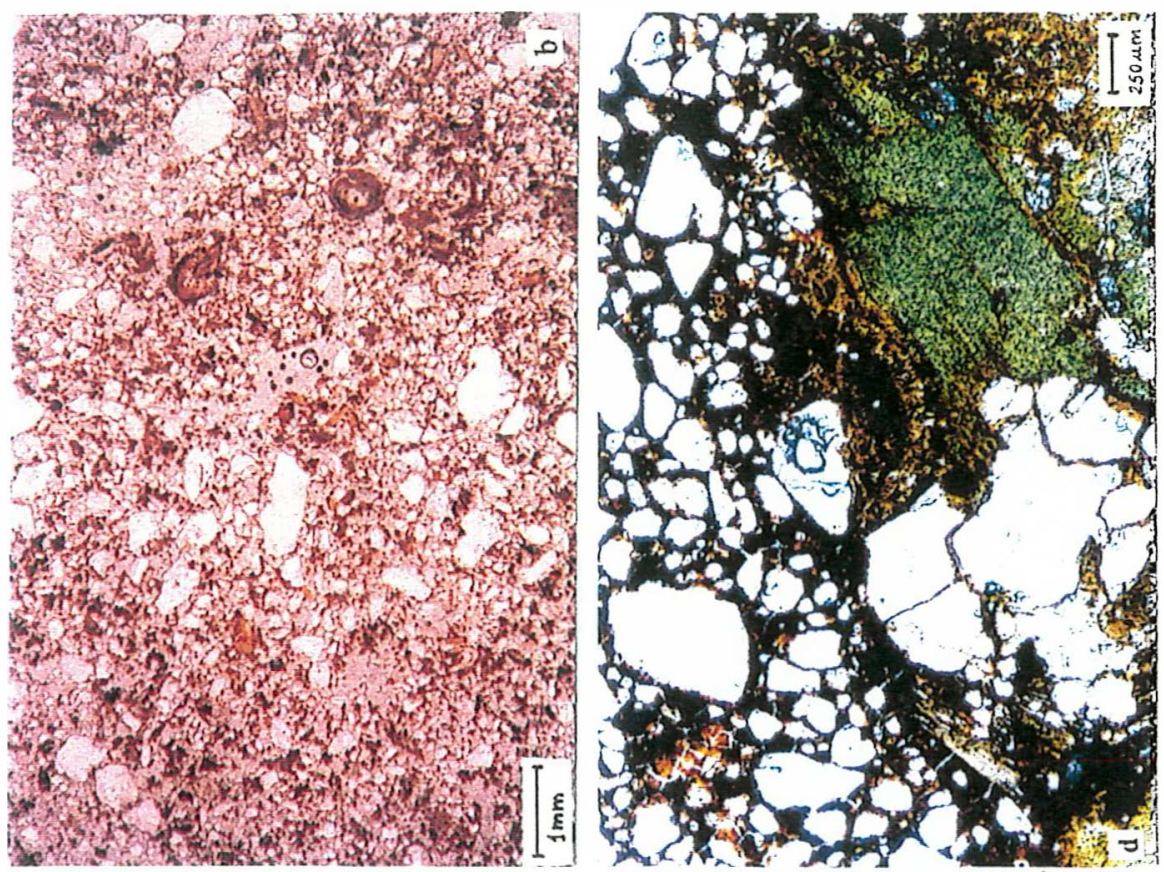

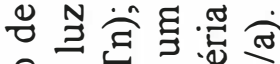

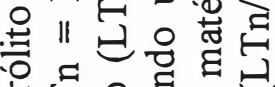

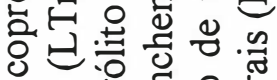

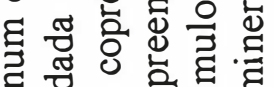

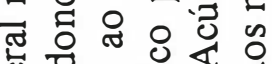

ब $0 \cdot \overline{0}$

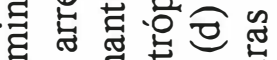

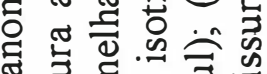

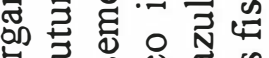

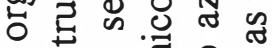

.

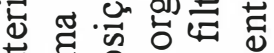

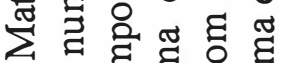

ชิ

幽 ह

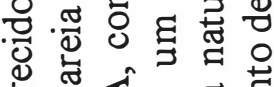

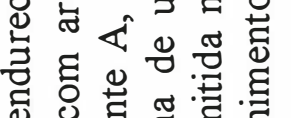

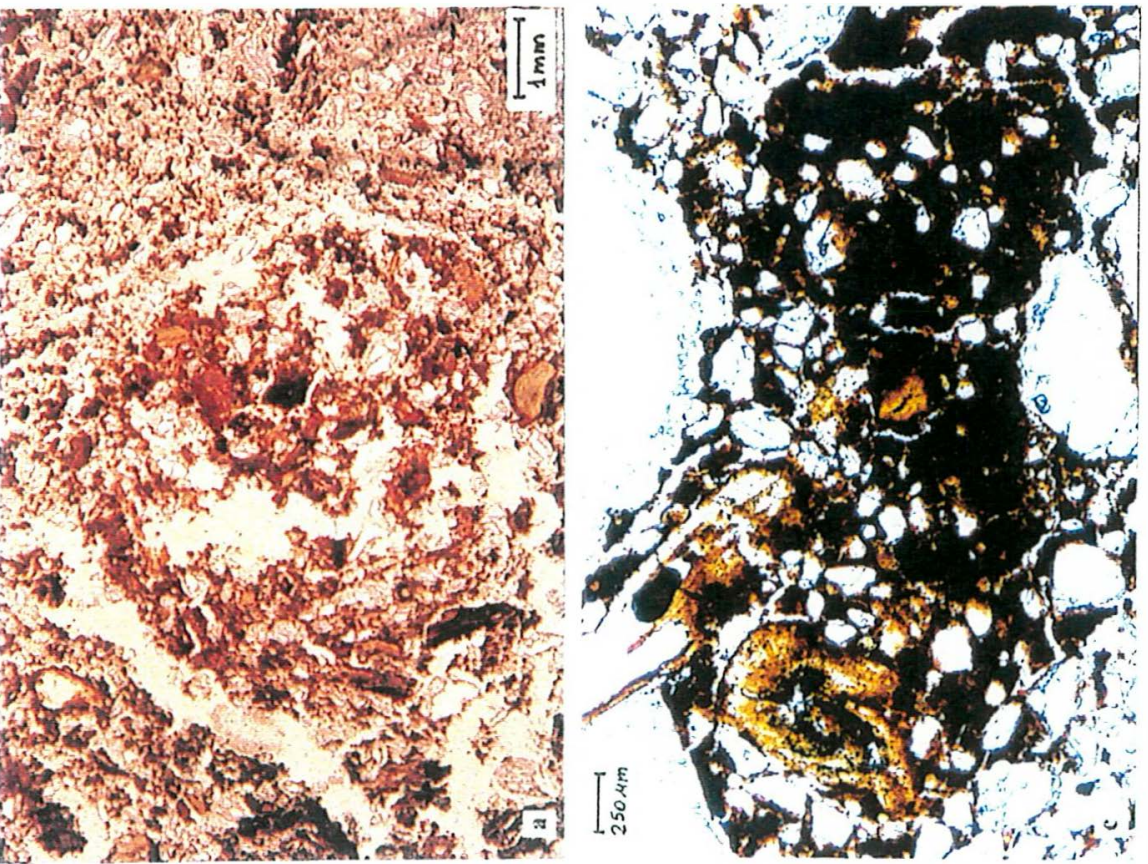

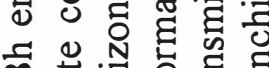

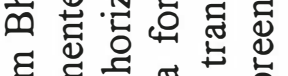

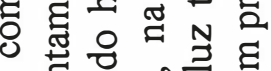

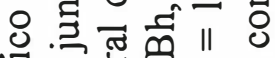

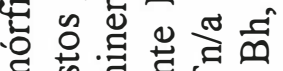

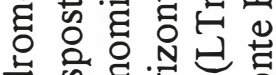

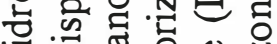

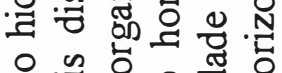

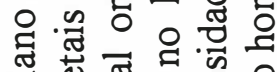

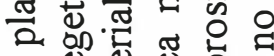

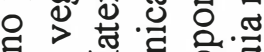

क 究 究

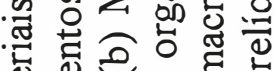

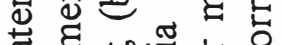

艺

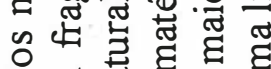

ᄋ छ 完 ઘ छ

ช ช

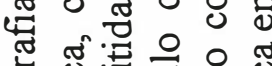

总 లో:

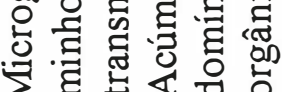

$\nabla$

$\pi$

营 


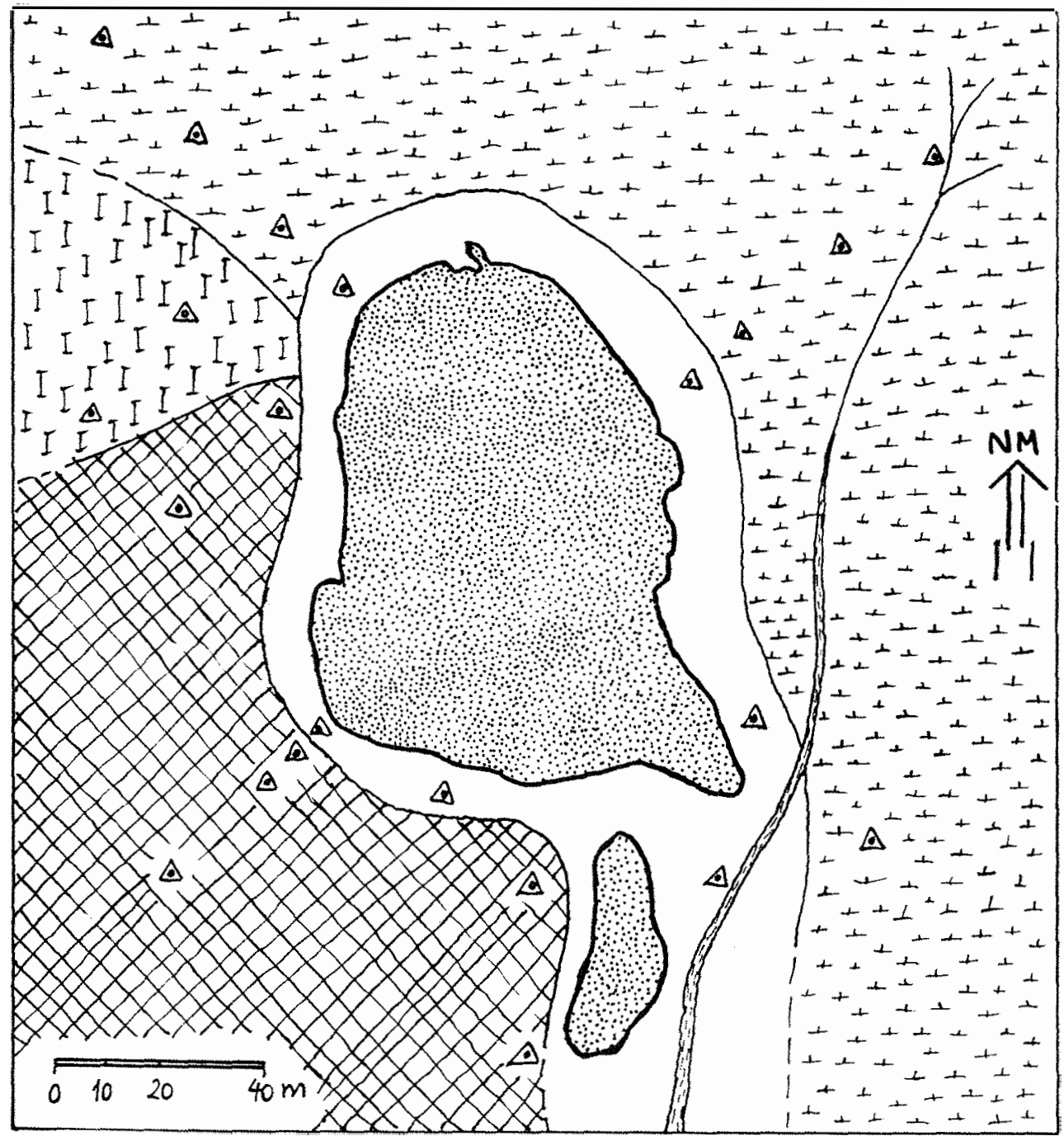

\section{Legenda:}

Bruno-muito-escuro, endurecido

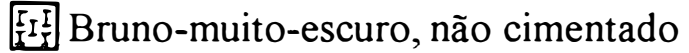

Cinzento-escuro a bruno-acinzentado-muito-escuro, manchado, não cimentado

Areias brancas dispostas sobre a rocha, a menos de $1 \mathrm{~m}$ de profundidade

Colina

\section{A Pontos de sondagem}

Figura 15 - Distribuição e variabilidade do horizonte B espódico nos solos da planície hidromórfica. 
orgânica menos pronunciado em relação ao volume 8. A distribuição da matéria orgânica é heterogênea, com menor quantidade na porção superior, concentrando-se em domínios arredondados, milimétricos, com até $5 \mathrm{~mm}$ de diâmetro (Figura 16a). Em profundidade estes domínios coalescem, formando uma camada escura, com porções de até $1 \mathrm{~cm}$ de diâmetro apresentando areia branca. $\mathrm{O}$ aspecto da matéria orgânica é semelhante ao volume anterior, com um plasma orgânico preenchendo os espaços entre os grãos. Este conjunto distribui-se na maior parte da área, na porção ao norte e a leste da colina (Figura 15), mostrando relação com a presença do eixo de drenagem e com as porções da colina com os contornos mais recortados. Abaixo dele encontra-se material mais argiloso e claro (volume 10). Em uma faixa a noroeste da colina, situada entre os dois conjuntos anteriores, o horizonte $\mathrm{Bh}$ é bruno-muito-escuro, com característica intermediárias. $\mathrm{O}$ enriquecimento em matéria orgânica é contínuo, sem domínios de areia branca e a consistência é solta.

- Volume 10: conjunto claro subsuperficial, (Horizonte $\mathrm{Cg}$ ) cinzento-claro a brunoacinzentado-claro, areno-argiloso a argilo-arenoso. A estrutura é maciça, com alguns pedotúbulos na porção superior apresentando material enriquecido em matéria orgânica (Figura 16b). Em profundidade o material torna-se mais claro (branco quando seco) e uniforme. O plasma tem estrutura plásmica insépica a latissépica, podendo ocorrer pápulas relacionadas com minerais pseudomorfos (Figura 16c). A distribuição deste conjunto mostra relação com o volume 9 , constituído pelo horizonte Bh solto sobrejacente. $\mathrm{O}$ conjunto claro começa a aparecer após a faixa composta por areia branca disposta diretamente sobre a rocha, em posições mais afastadas da colina e acima da camada de saprolito, coincidindo com o aprofundamento abrupto da rocha (Figura 6b).

- Volume 11: saprolito de granito, horizonte Cgr, bruno-claro-acinzentado a oliva, com grande quantidade de micas e feldspatos alterados. Esse conjunto apresenta concentrações de matéria orgânica em canais de raízes e pedotúbulos (Figura 16d), relacionadas ao horizonte $\mathrm{Bh}$ sobrejacente. Esse saprolito ocorre na periferia da colina, após a faixa de areia branca sobre a rocha que ocupa a zona de contato. Nas porções mais afastadas da colina, este material dispõe-se abaixo do conjunto claro (volume 10). 


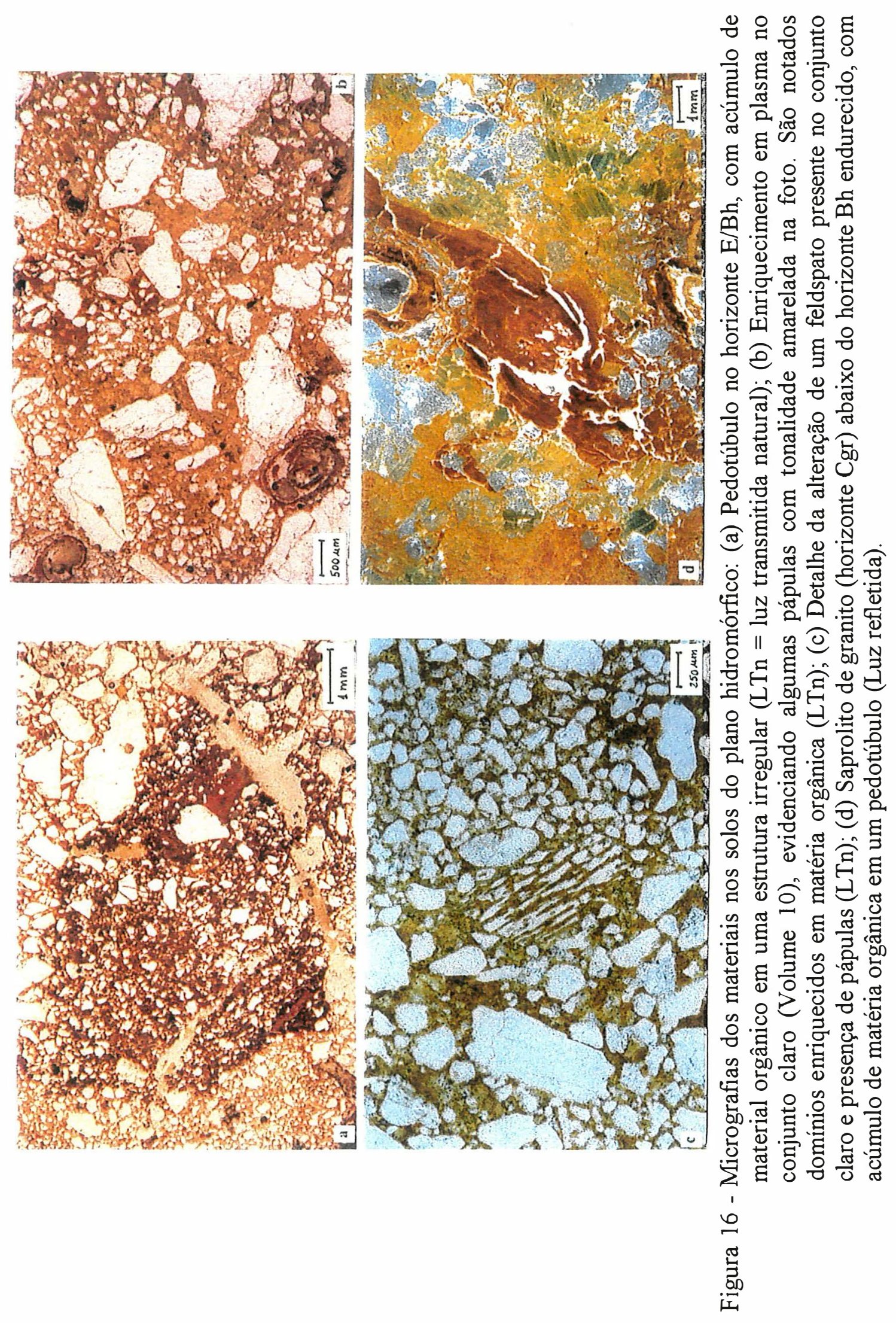


Os conjuntos pedológicos na planície hidromórfica distribuem-se de forma simétrica em torno da colina, com ocorrência de areia branca diretamente sobre a rocha a pequena profundidade $(<1 \mathrm{~m})$ em uma faixa circundando a colina (Figuras $9 \mathrm{e}$ 15). A medida que se afasta da colina, a rocha se aprofunda e se observam volumes enriquecidos em matéria orgânica (Bh) abaixo da camada de areia branca. Abaixo do horizonte $\mathrm{Bh}$ endurecido encontra-se um saprolito (Horizonte $\mathrm{Cgr}$ ), presente em menor profundidade $(1,4 \mathrm{~m})$ e constatado também na periferia da colina nas porções em que se nota o aprofundamento abrupto da rocha na planície. $\mathrm{O}$ conjunto claro areno-argiloso a argilo-arenoso (Volume 10) distribui-se nas porções mais afastadas da colina, abaixo do horizonte Bh solto.

\subsubsection{Atividade das minhocas nos solos da planície hidromórfica}

As minhocas são o grupo de animais com maior influência nos solos na planície hidromórfica. Os exemplares capturados pertencem à família Glossoscolecidae ${ }^{1}$, com dois tipos, um com cerca de $1 \mathrm{~cm}$ de diâmetro e outro de 5 a $6 \mathrm{~mm}$ de diâmetro, com comprimento superior a $60 \mathrm{~cm}$ nos exemplares imaturos (Figuras 17a). Esses animais formam inúmeros montículos na superfície do solo, com densidade média de 3,3 a 3,4 por metro quadrado (Tabela 1). Esses montículos são cônico-arredondados com dimensões de cerca de $14 \mathrm{~cm}$ de altura e $17 \mathrm{~cm}$ de diâmetro médio basal em média, com um canal de circulação de 5 a $6 \mathrm{~mm}$ de diâmetro, correspondente ao tipo mais fino e comprido de minhoca.

O transporte de materiais e deposição nos montículos superficiais ocasiona modificações na estrutura do solo, com formação agregados granulares, de 0,6 a 1,2 cm de diâmetro e aspecto semelhante aos encontrados no solo adjacente (Figura 17b). A quantidade de material depositado atinge cerca de $3 \mathrm{~kg} \mathrm{~m}^{-2}$, o que eqüivale, aproximadamente, a uma camada de $3 \mathrm{~mm}$ de solo ou aproximadamente $30 \mathrm{t} \mathrm{ha}^{-1}$ de solo. A dinâmica de transporte não foi avaliada, mas supõe-se contínua e rápida

\footnotetext{
${ }^{\prime}$ Comunicação pessoal. Dr ${ }^{\mathrm{a}}$ Ana G. Moreno. Universidad Complutense. Madrid España: E-mail: agmoreno@eucmax.sim.ucm.es.
} 

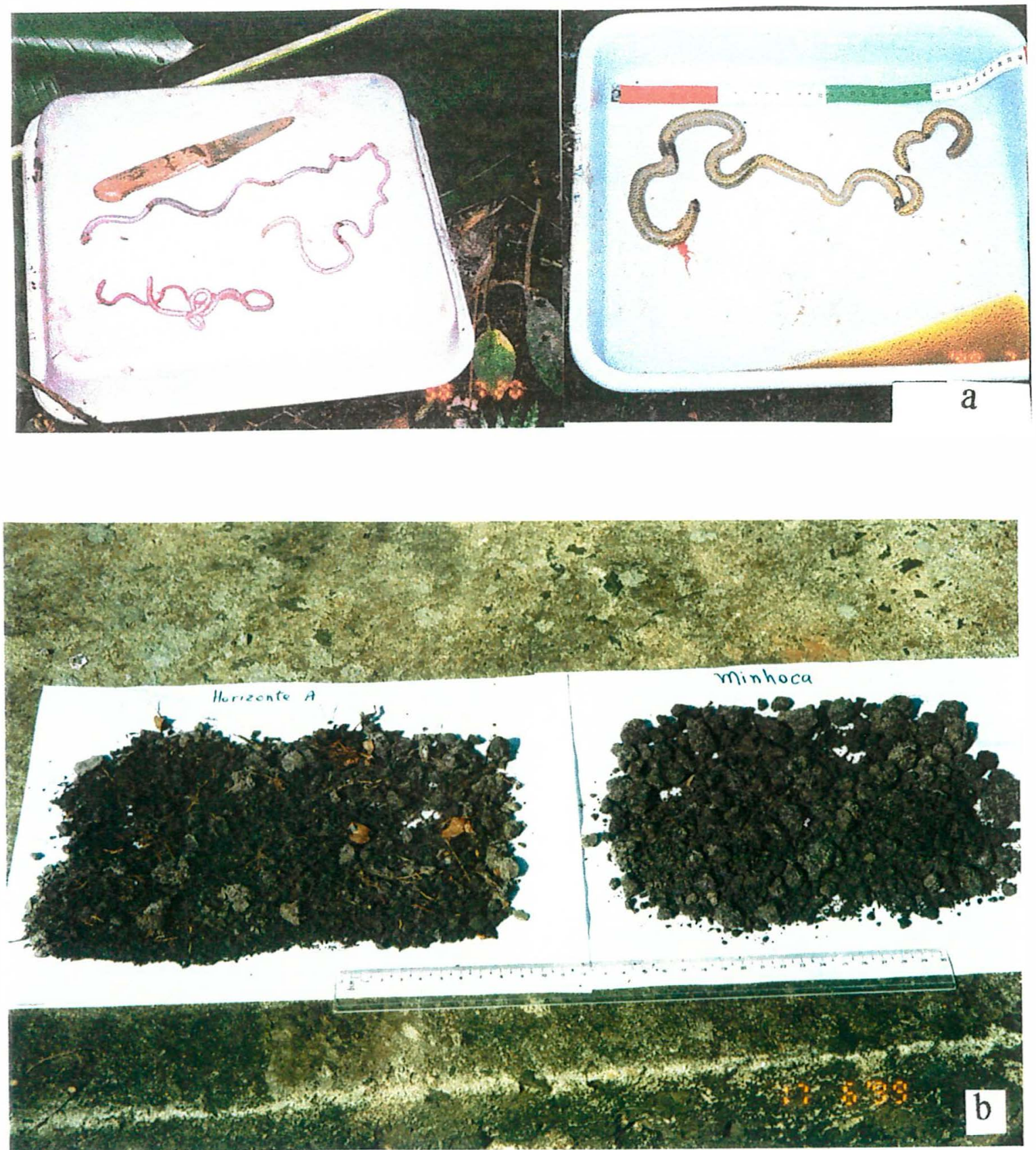

Figura 17 - (a) Exemplares de minhoca pertencentes à família Glossoscolecidae coletados nos solos da planície hidromórfica; (b) Ilustração da ação desses animais na esirutura do conjunto superficial do solo, sendo à esquerda o material do horizonte $\mathrm{A}$ e à direita o material dos montículos de minhoca. 
renovação, face ao desgaste periódico pela chuva e pela presença comum de deposições recentes, bruno-escuras, brilhantes e mais úmidas, constatadas durante o trabalho de campo.

Tabela 1. Aspectos descritivos dos montículos de minhoca em duas áreas distintas na planície hidromórfica.

\begin{tabular}{|c|c|c|}
\hline Atributo analisado & Ärea 1 ${ }^{(\mathrm{n})}$ & Área $2^{(1)}$ \\
\hline \multicolumn{3}{|l|}{ Densidade (número $\mathrm{m}^{-2}$ ) } \\
\hline Média & 3,3 & 3,4 \\
\hline Desvio padrão & 0,9 & 1,2 \\
\hline Amplitude & $1,8-5,3$ & $1,3-5,5$ \\
\hline \multicolumn{3}{|l|}{ Altura (cm) } \\
\hline Média & 13,9 & 13,8 \\
\hline Desvio padrão & 2,0 & 1,2 \\
\hline Amplitude & $5-33$ & $6-30$ \\
\hline \multicolumn{3}{|l|}{ Diâmetro basal (cm) } \\
\hline Média & 16,2 & 16,9 \\
\hline Desvio padrão & 1,8 & 1,6 \\
\hline Amplitude & $8-36$ & $8-32$ \\
\hline \multicolumn{3}{|l|}{$\operatorname{Massa}\left(\mathrm{kg} \mathrm{m}^{-2}\right)$} \\
\hline Média & 3,20 & 3,48 \\
\hline Desvio padrão & 0,97 & 1,22 \\
\hline Amplitude & $1,8-5,2$ & $1,5-5,2$ \\
\hline
\end{tabular}

1. Médias de 25 parcelas. Área 1 , a cerca de $10 \mathrm{~m}$ do perfil Pl e área 2 , a cerca de $10 \mathrm{~m}$ do perfil P3, na planície hidromórfica.

Em subsuperficie, a influência desses animais se manifesta nos pedotúbulos, que são dos tipos granotubos, isotubos e estriotubos. Os agrotubos ocorrem no horizonte $\mathrm{Bh}$ e têm de 3 a $15 \mathrm{~mm}$ de diâmetro, constituídos principalmente por areia fina, mais pobres em matéria orgânica e com aspecto mais claro que a matriz. Os isotubos e estriotubos, presentes principalmente no conjunto claro (Volume 10) e no saprolito (Volume 11), têm de 4 a $12 \mathrm{~mm}$ de diâmetro, com constituição mais heterogênea, mostrando acúmulo de matéria orgânica e, em algumas porções, concentração de areia grossa. Essas estruturas evidenciam intensa mistura de materiais no perfil provocado pelas minhocas. 


\subsection{Densidade do solo}

Os materiais na parte superior das vertentes, no topo e em meia encosta, apresentam densidade do solo baixa no conjunto latossólico, variando de 1,17 a $1,34 \mathrm{~g}$ $\mathrm{cm}^{-3}$ (Figura 18 e Anexo C). A densidade neste caso relaciona-se com a estrutura, que é do tipo granular muito pequena, formando um conjunto muito poroso. Em profundidade, na camada correspondente a alterita, a densidade desses solos atingiu 1,27 a $1,33 \mathrm{~g} \mathrm{~cm}^{-3}$.

Os perfis na borda da colina evidenciam incremento na densidade do solo no conjunto manchado intermediário (Horizonte $\mathrm{BCg}$ ), em relação ao observado na parte superior das seqüências, variando de 1,33 a $1,45 \mathrm{~g} \mathrm{~cm}^{-3}$. Em profundidade houve um aumento da densidade desses solos, passando para 1,49 a $1,59 \mathrm{~g} \mathrm{~cm}^{-3}$ no conjunto acinzentado. Esse incremento na densidade pode ser relacionado com a disposição mais adensada desses materiais, como também a maior quantidade de areia.

Os solos na planície hidromórfica apresentam baixa densidade na camada superficial, com valores de $0,99 \mathrm{~g} \mathrm{~cm}^{-3}$ no coprólito e $0,73 \mathrm{~g} \mathrm{~cm}^{-3}$ no horizonte $\mathrm{A}$. Em subsuperficie houve aumento na densidade do solo, passando para $1,66 \mathrm{~g} \mathrm{~cm}^{-3}$ no conjunto eluvial e, em torno de $1,51 \mathrm{~g} \mathrm{~cm}^{-3}$ no horizonte $\mathrm{Bh}$.

\subsection{Granulometria do solo}

Os solos do topo da colina e em meia encosta apresentam uma camada superficial mais arenosa, com teores de argila entre 180 e $190 \mathrm{~g} \mathrm{~kg}^{-1}$ nos primeiros 10 $\mathrm{cm}$ de profundidade (Figura 19a e Anexo C). Em profundidade, observa-se aumento da quantidade de argila, passando para 300 a $360 \mathrm{~g} \mathrm{~kg}^{-1}$ no conjunto latossólico. Na base destes perfis, nota-se diminuição do teor de argila.

A variação lateral na granulometria do solo da colina foi variável nas situações analisadas. Em uma seqüência (TR2/I) observa-se diminuição dos teores de argila na borda da colina, em relação àqueles presentes em meia encosta, chegando a valores entre 190 e $220 \mathrm{~g} \mathrm{~kg}^{-1}$ no material latossólico. Na outra seqüência, correspondente ao perfil TR3/I, não se nota variação lateral no conteúdo de argila no 


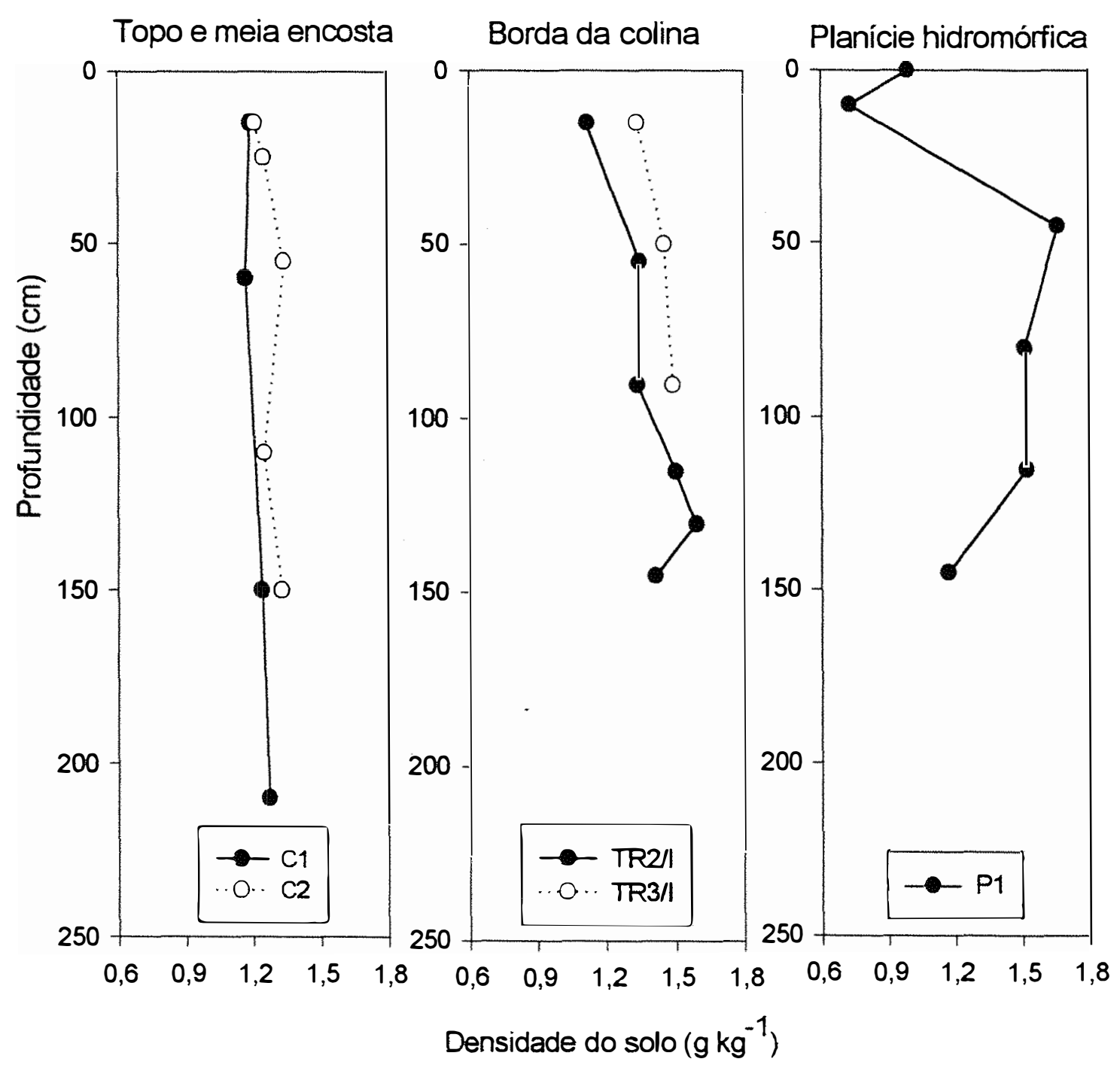

Figura 18 - Densidade do solo nos perfis analisados na seqüência em Cucuí. 
conjunto latossólico, que permanece com $320 \mathrm{~g} \mathrm{~kg}^{-1}$ de argila na borda da colina. As maiores diferenças na composição granulométrica, neste caso, se dão no sentido vertical, entre o conjunto latossólico e a alterita acinzentada hidromórfica, que tem apenas 80 a $140 \mathrm{~g} \mathrm{~kg}^{-1}$ de argila (Figura 19b).

A perda de argila evidenciada na alterita acinzentada da borda da colina se acentua em direção à planície hidromórfica, próximo à zona de contato, onde se observa areia branca disposta diretamente sobre a rocha, com apenas 20 a $40 \mathrm{~g} \mathrm{~kg}^{-1} \mathrm{de}$ argila. O material em superfície na porção plana, próximo ao contato com a borda da colina apresenta de 100 a $120 \mathrm{~g} \mathrm{~kg}^{-1}$ de argila, mostrando aspecto heterogêneo, pela mistura com matéria orgânica, muito abundante nesta porção.

Com respeito à distribuição das frações granulométricas, os materiais da parte superior das vertentes $\mathrm{C} 1$ e $\mathrm{C} 2$, mostram predominio de areia fina na camada superficial, com relação areia fina/areia total de 0,34 a 0,47 no horizonte A (Figura 19a). Em profundidade, observa-se um aumento na quantidade de cascalho (2 a $20 \mathrm{~mm}$ ) e maior quantidade de areia grossa, com aumento do diâmetro médio e diminuição da relação areia fina/areia total. A maior quantidade de areia fina nas camadas superficiais é uma evidência do intemperismo químico intenso, que provoca fragmentação progressiva do quartzo. Da mesma forma, os perfis na borda da colina apresentam gradual incremento, em profundidade, na quantidade de cascalho, areia grossa e muito grossa. A maior quantidade de cascalho e areia grossa observada em subsuperficie no perfil TR3/I pode ser relacionada com a presença de nódulos ferruginosos e gibbsíticos, abundantes neste material.

Os solos na planicie hidromórfica mostram granulometria semelhante entre o horizonte A e os montículos formados pelas minhoca, com teor de argila inferior a $60 \mathrm{~g} \mathrm{~kg}^{1}$. Esses materiais são praticamente desprovidos de cascalho e areia muito grossa, com predominio da fração areia fina e, são semelhantes quanto ao diâmetro médio e relação areia fina/areia total. A granulométrica, juntamente com outros aspectos morfológicos, tais como cor, estrutura e composição, apontam para uma ação marcante das minhocas sobre a camada superficial bruno-escura dos solos da planície hidromórfica, fazendo supor que todo este material tenha sido mobilizado pelos animais. 
Relação areia fina/areia total e diâmetro médio $(\mathrm{mm})$
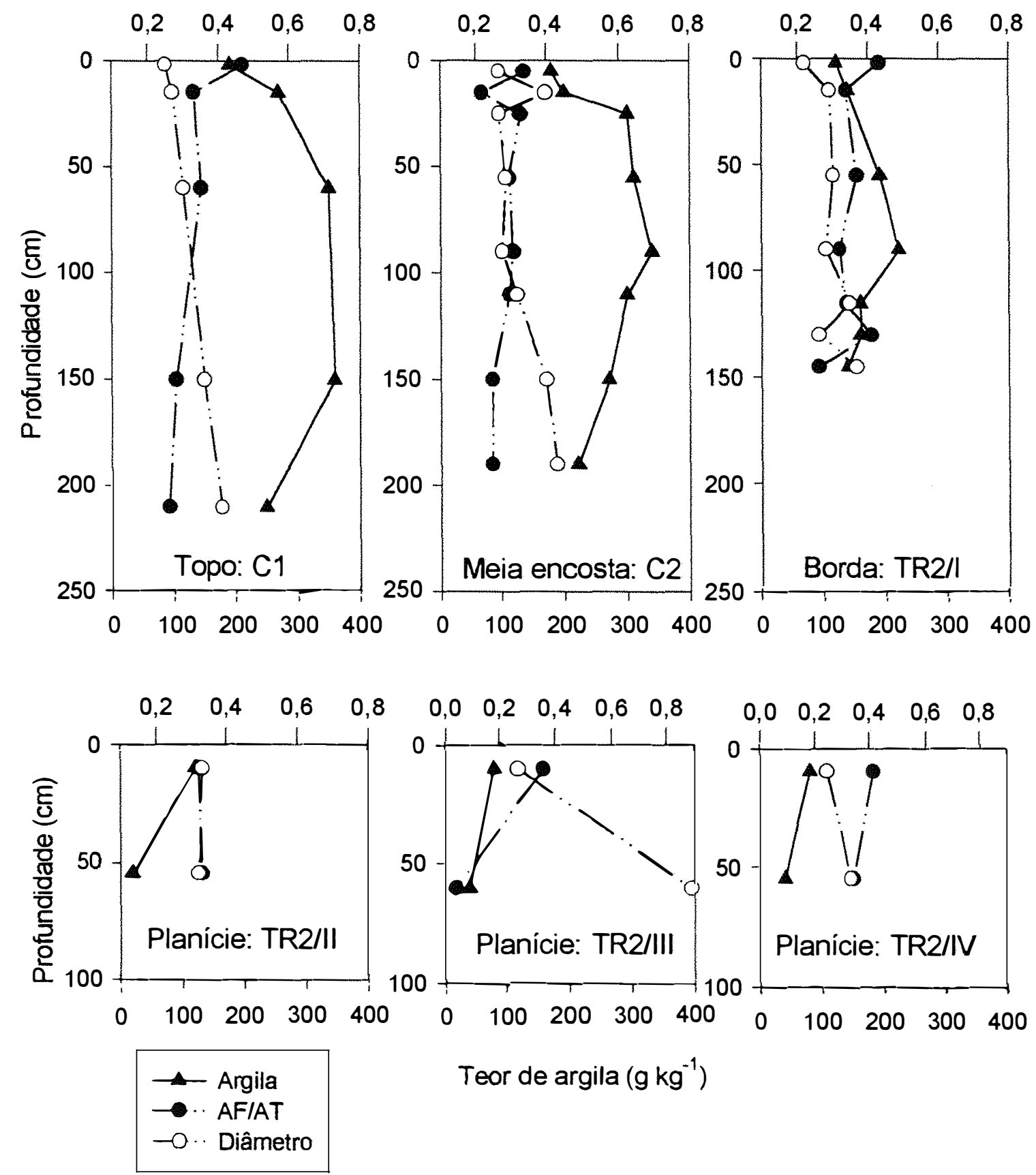

Figura 19a - Variação vertical na granulometria do solo, incluindo teores de argila, relação areia fina/areia total e diâmetro médio das areias $(\mathrm{mm})$. 
Relação areia fina/areia total e diâmetro médio $(\mathrm{mm})$
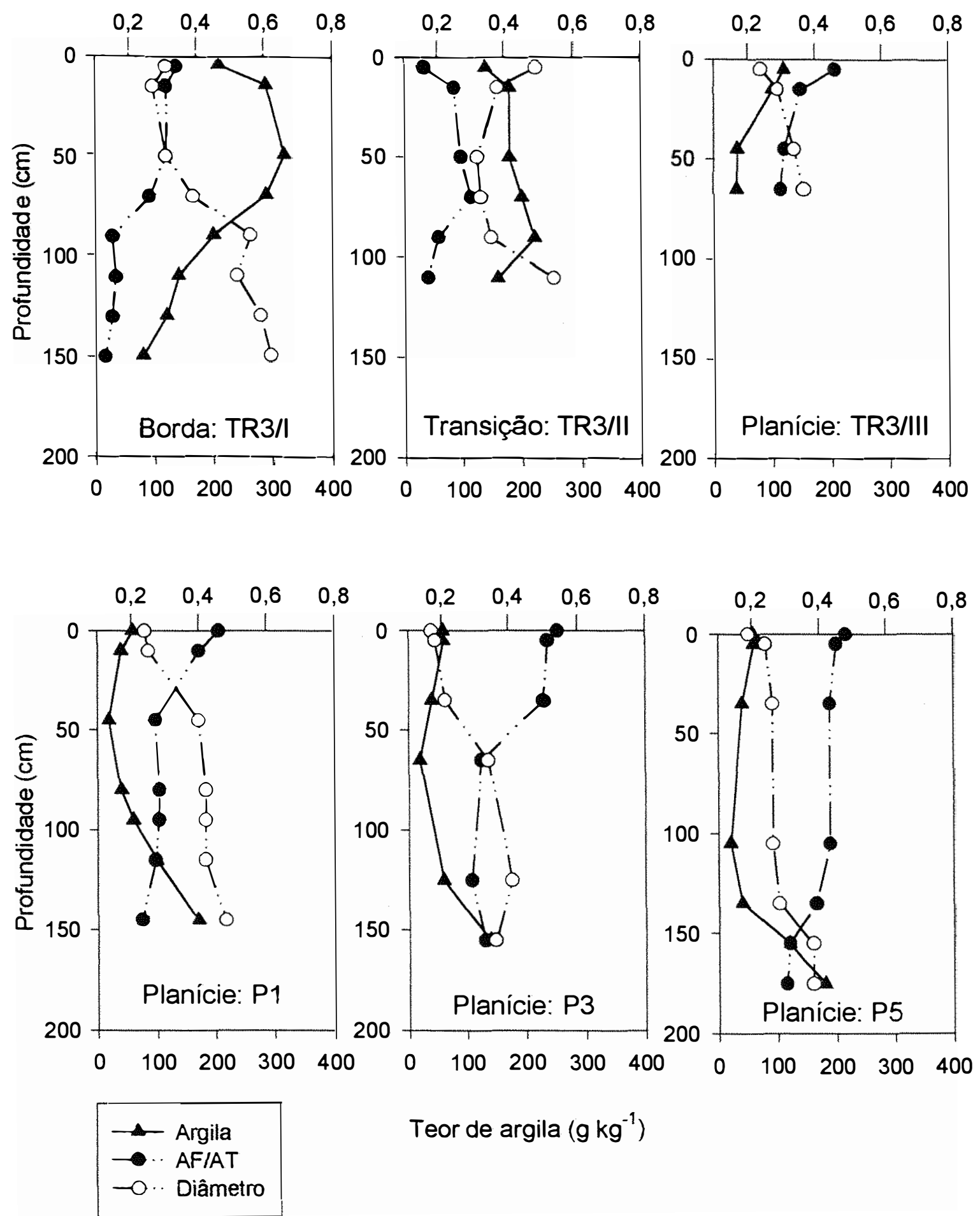

Figura 19b - Variação vertical na granulometria do solo, incluindo teores de argila, relação areia fina/areia total e diâmetro médio das areias $(\mathrm{mm})$. 
Em profundidade, os solos da planície hidromórfica apresentam aumento na quantidade de cascalho, areia grossa e muito grossa, o que se reflete no decréscimo da relação areia fina/areia total e aumento do diâmetro médio. O saprolito de granito e o conjunto claro subsuperficial mostram aumento na quantidade de material fino, chegando a $180 \mathrm{~g} \mathrm{~kg}^{-1}$ de argila.

A relação silte/argila situa-se em torno de 0,5 no conjunto latossólico dos solos na parte superior da colina. Na borda da colina os valores variam de 0,6 a 1,0 no mesmo material.

\subsection{Atributos químicos do solo}

\subsection{1 pH, elementos trocáveis, carbono orgânico e formas de ferro}

A acidez do solo é alta, com pH em água variando de 4,4 a 5,2 nos solos da colina, diminuindo para 3,7 a 4,9 nos solos da planície hidromórfica. $\mathrm{O} \mathrm{pH}$ em $\mathrm{KCl}$ foi sistematicamente inferior ao $\mathrm{pH}$ em água, resultando em valores de $\Delta \mathrm{pH}$ negativo, o que caracteriza solos eletronegativos (Tabelas 2 e 3 ).

A soma de bases é baixa em todos os materiais, não havendo diferenças nítidas entre os diferentes solos. Este resultado, que se relaciona com valores de saturação por bases (V) inferiores a $10 \%$ na maioria dos casos, evidencia um ambiente com intensa remoção de bases do solo.

A CTC a pH 7,0 mostra ligação com os teores de carbono orgânico e com a quantidade de argila. Na porção superior da colina, o horizonte A apresenta alto teor de carbono orgânico, em torno de $99 \mathrm{~g} \mathrm{~kg}^{-1}$, evidenciando alta CTC. Os menores valores de CTC são da alterita, que apresenta baixo teor de argila e de carbono orgânico. Nos solos da borda da colina, o comportamento da CTC e do carbono orgânico são semelhantes ao do topo. Na planície hidromórfica, os solos apresentam maior teor de carbono orgânico nas camadas superficiais, variando de 28 a $40 \mathrm{~g} \mathrm{~kg}^{-1}$ e no horizonte Bh endurecido, que tem $35 \mathrm{~g} \mathrm{~kg}^{-1}$ de carbono orgânico. No Bh solto este elemento apresenta teores mais baixo, em torno de $10 \mathrm{~g} \mathrm{~kg}^{-1}$ (Tabela 3). A maior CTC observada no perfil P1 (com Bh 


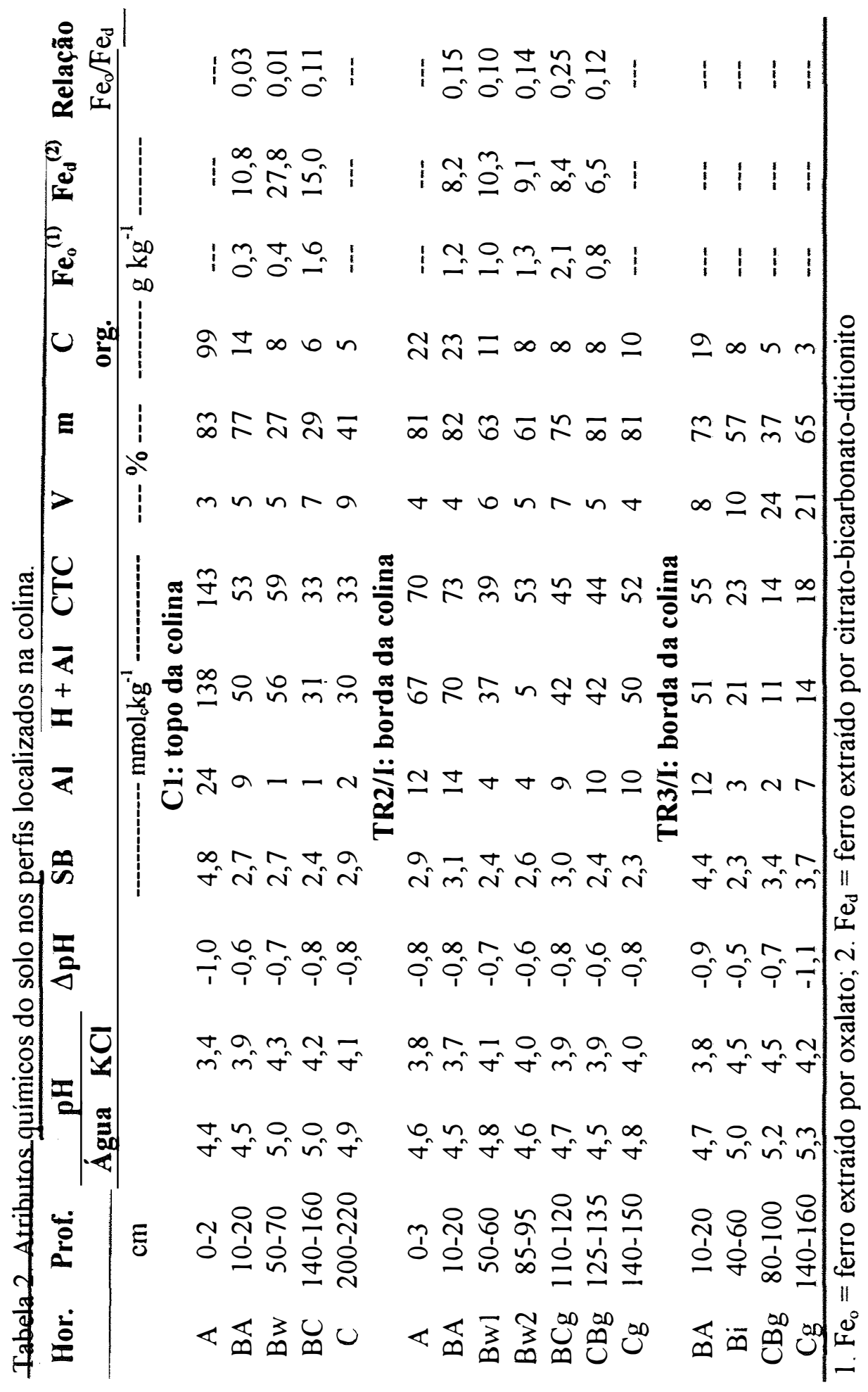




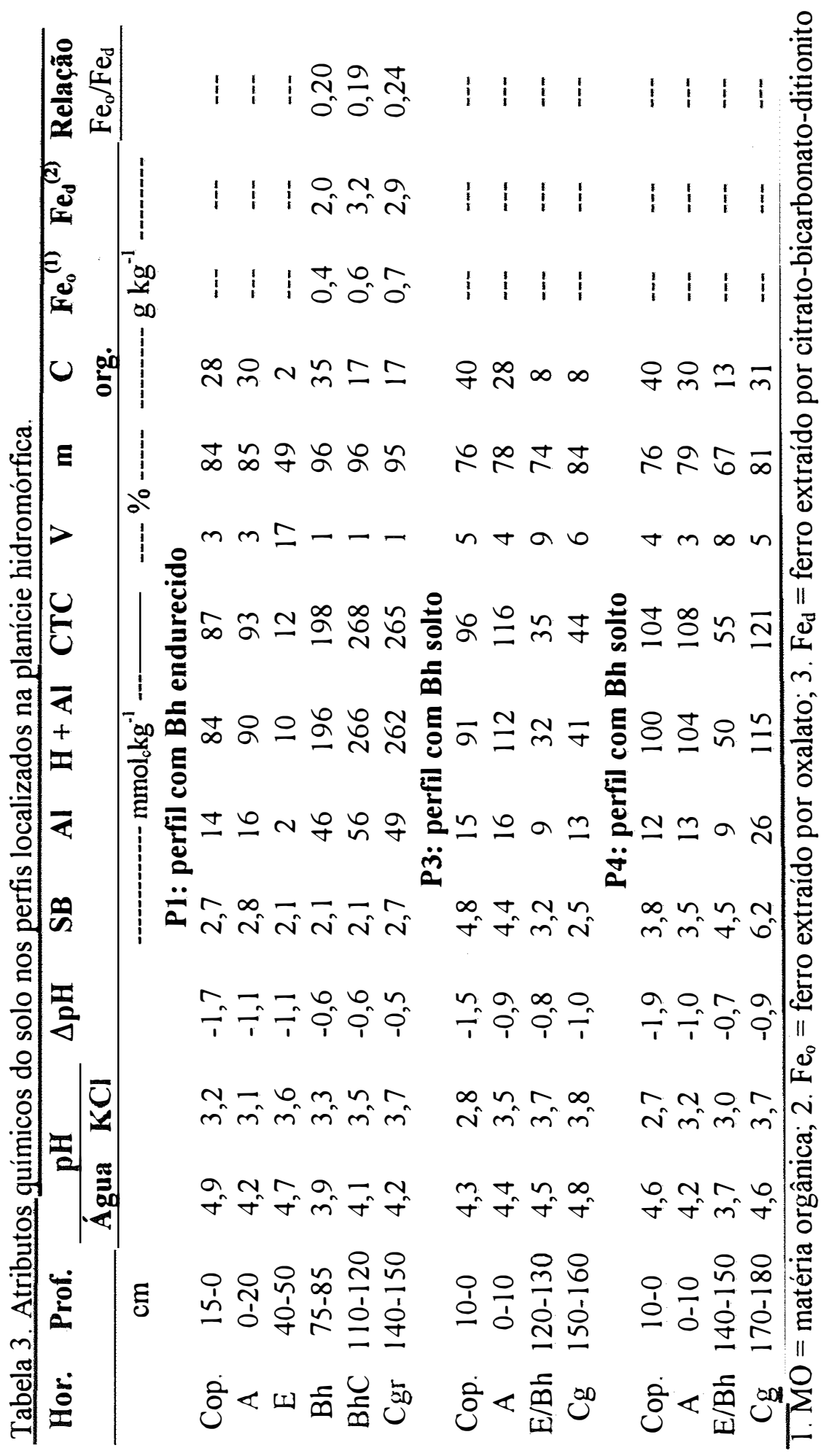


endurecido), possivelmente esteja relacionada ’a extração de compostos organominerais amorfos pelo acetado de $\mathrm{Ca}$. Estes compostos seriam formados com alumínio, abundante neste material, o que se manifesta pelos altos teores deste elemento na forma trocável, extraidos por $\mathrm{KCl}$.

O teor de $\mathrm{Al}$ trocável nos solos do topo da colina foi alto no horizonte $\mathrm{A}$, refletindo sua elevada saturação por $\mathrm{Al}(\mathrm{m})$, que atingiu $83 \%$. Em profundidade houve acentuada redução no teor de $\mathrm{Al}$ trocável neste solo. $\mathrm{Na}$ borda da colina o teor de $\mathrm{Al}$ trocável foi alto na superfície do solo, diminuindo no conjunto latossólico e voltando a aumentar na alterita, chegando a valores superiores aos encontrados na porção superior das seqüências. Os solos da planície hidromórfica apresentam teores de Al trocável relacionados com a quantidade de matéria orgânica.

Os teores de ferro extraídos por citrato-bicarbonato-ditionito $\left(F e_{d}\right)$ são mais altos no topo da colina, especialmente nos conjuntos latossólico e intermediário. $\mathrm{Na}$ borda da colina a quantidade de $\mathrm{Fe}_{\mathrm{d}}$ é maior no conjunto latossólico e decresce em profundidade. Na planície hidromórfica os teores de $\mathrm{Fe}_{\mathrm{d}}$ são baixos com pequena variação em profundidade. Para o ferro extraido por oxalato de amônio $\left(\mathrm{Fe}_{\mathrm{o}}\right)$, os teores mais elevados foram observados no conjunto intermediário no topo e na borda da colina.

A relação $\mathrm{Fe}_{\mathrm{o}} / \mathrm{Fe}_{\mathrm{d}}$, empregada como indicadora do grau de cristalinidade dos óxidos de ferro (Schwertmann \& Taylor, 1989), evidencia predomínio de materiais bem cristalizados, especialmente nas porções do perfil com drenagem livre, como nos horizontes BA e Bw no topo da colina. Os perfis da borda da colina e da planície hidromórfica tiveram maior relação, mostrando um efeito da hidromorfia na redução do grau de cristalinidade dos óxidos de ferro.

\subsubsection{Elementos extraídos pelo ataque sulfúrico}

Os teores de silício nos horizontes superficiais dos solos do topo da colina são baixos, dando conta de um ambiente com intensa dessilicicação. Os valores de $\mathrm{Ki}$ destes materiais são próximos de 0,5 , indicando uma mineralogia oxídica (Tabela 4). Em profundidade, a quantidade de $\mathrm{Si}, \mathrm{Al}$ e Fe foi crescente. 
Tabela 4. Composição química do solo obtida a partir do ataque sulfúrico.

\begin{tabular}{|c|c|c|c|c|c|c|c|c|c|c|}
\hline Hor. & Prof. & $\mathrm{Si}$ & Al & $\mathbf{F e}$ & $\mathbf{T i}$ & $\mathbf{K}$ & Ca & Mg & $\mathbf{K i}$ & $\mathbf{K r}$ \\
\hline & $\mathrm{cm}$ & & & (n- & $\mathrm{kg}^{-1}$ & & & ---- & & \\
\hline \multicolumn{11}{|c|}{ C1: topo da colina } \\
\hline BA & $10-20$ & 12,2 & 50,8 & 20,0 & 4,5 & 4,0 & 0,13 & 0,58 & 0,46 & 0,39 \\
\hline $\mathrm{Bw}$ & $50-70$ & 23,5 & 80,6 & 36,6 & 7,1 & 4,8 & 0,12 & 1,27 & 0,56 & 0,46 \\
\hline $\mathrm{BC}$ & $140-160$ & 20,2 & 82,2 & 37,7 & 7,2 & 5,0 & 0,12 & 1,44 & 0,47 & 0,39 \\
\hline $\mathrm{C}$ & $200-220$ & 46,5 & 104,8 & 51,9 & 8,2 & 11,0 & 0,09 & 8,10 & 0,85 & 0,69 \\
\hline \multicolumn{11}{|c|}{ TR2/I: borda da colina } \\
\hline BA & $10-20$ & 12,7 & 34,6 & 10,2 & 3,7 & 1,7 & 0,13 & 0,92 & 0,70 & 0,62 \\
\hline Bw1 & $50-60$ & 13,2 & 46,5 & 12,5 & 4,6 & 1,8 & 0,15 & 1,11 & 0,54 & 0,48 \\
\hline $\mathrm{BCg}$ & $110-120$ & 14,1 & 47,5 & 9,5 & 5,1 & 1,5 & 0,18 & 1,01 & 0,57 & 0,52 \\
\hline $\mathrm{CBg}$ & $125-135$ & 12,7 & 52,4 & 8,5 & 5,2 & 1,6 & 0,14 & 1,06 & 0,47 & 0,43 \\
\hline $\mathrm{Cg}$ & $140-150$ & 8,5 & 34,6 & 3,4 & 4,0 & 1,4 & 0,12 & 0,90 & 0,47 & 0,45 \\
\hline \multicolumn{11}{|c|}{ TR3/I: borda da colina } \\
\hline $\mathrm{Bi}$ & $40-60$ & 4,7 & 78,4 & 21,8 & 4,6 & --- & $\cdots$ & -- & 0,11 & 0,10 \\
\hline $\mathrm{CBg}$ & $80-100$ & 19,3 & 100,0 & 60,1 & 5,5 & -- & -- & $\cdots$ & 0,37 & 0,29 \\
\hline $\mathrm{Cg}$ & $140-160$ & 23,5 & 87,0 & 46,8 & 5,4 & -- & --- & $\cdots$ & 0,52 & 0,41 \\
\hline \multicolumn{11}{|c|}{ P1: planície hidromórfica, Bh endurecido } \\
\hline Cop. & $15-0$ & 4,7 & 4,3 & 0,4 & 1,0 & 3,50 & 0,08 & 0,09 & 2,10 & 2,02 \\
\hline A & $0-20$ & 8,9 & 2,7 & 0,5 & 0,9 & 3,60 & 0,10 & 0,06 & 6,33 & 5,82 \\
\hline $\mathrm{E}$ & $40-50$ & 7,1 & 1,6 & 0,9 & 0,5 & 3,40 & 0,06 & 0,05 & 8,50 & 6,65 \\
\hline $\mathrm{Bh}$ & $75-85$ & 5,2 & 3,8 & 0,1 & 0,6 & 3,30 & 0,07 & 0,05 & 2,63 & 2,61 \\
\hline $\mathrm{BhC}$ & $110-120$ & 9,4 & 20,6 & 2,5 & 1,3 & 4,00 & 0,08 & 0,43 & 0,88 & 0,83 \\
\hline $\mathrm{Cgr}$ & $140-150$ & 28,2 & 57,8 & 2,9 & 3,2 & 3,48 & 0,20 & 3,91 & 0,93 & 0,91 \\
\hline \multicolumn{11}{|c|}{ P3: planície hidromórfica, Bh solto } \\
\hline $\mathrm{Cg}$ & $150-160$ & 42,3 & 37,8 & 0,28 & 1,0 & -- & $\cdots$ & $\cdots$ & 2,14 & 2,14 \\
\hline \multicolumn{11}{|c|}{ P4: planície hidromórfica, Bh solto } \\
\hline $\mathrm{Cg}$ & $170-180$ & 41,4 & 38,4 & 0,28 & 0,2 & --- & $\cdots$ & -- & 2,07 & 2,06 \\
\hline \multicolumn{11}{|c|}{ P5: planície hidromórfica, Bh solto } \\
\hline $\mathrm{Cg}$ & $170-180$ & 60,6 & 59,5 & 2,1 & 2,3 & $\ldots$ & $-\cdots$ & $\cdots$ & 1,95 & 1,92 \\
\hline
\end{tabular}

$\mathrm{Na}$ borda da colina, os teores de Si são, em geral, menores em relação aos do topo. Os teores de $\mathrm{Al}$ e $\mathrm{Fe}$ são mais altos no perfil TR3/I em relação ao perfil TR2/I, o que pode ser relacionado com o acúmulo desses elementos na forma de micronódulos de gibbsita, enriquecidos em ferro.

Os solos na planície hidromórfica apresentam teores variáveis de $\mathrm{Si}$ e $\mathrm{Al}$, mais elevados na base dos perfis, no conjunto claro subsuperficial (Perfil P5, horizonte $\mathrm{Cg}$ ). A quantidade de $\mathrm{Si}$ em relação ao $\mathrm{Al}$ é maior quando comparada aos materiais da 
colina, resultando em valores de $\mathrm{Ki}$ variando entre 1 e 2. Os teores de $\mathrm{Si}$ e $\mathrm{Al}$ extraídos pelo ataque sulfúrico são baixos na camada superficial arenosa, constituída quase unicamente por quartzo. Os teores de Fe nesses solos são muito baixos, em decorrência do ambiente redutor.

Os teores de Ti são mais altos e uniformes nos solos da colina, variando entre 3,7 e $8,2 \mathrm{~g} \mathrm{~kg}^{-1}$. Nos materiais presentes na planície hidromórfica as concentrações de Ti variam entre 0,5 e $2,3 \mathrm{~g} \mathrm{~kg}^{-1}$. Essas variações podem estar ligadas a composição heterogênea do material de origem, sendo um elemento pouco móvel e característico de minerais muito estáveis ao intemperismo, como titanita, ilmenita, anatásio e rutilo.

Os teores de $\mathrm{Ca}$ e $\mathrm{Mg}$ são normalmente mais altos nos solos da colina em relação aos materiais da planície hidromórfica. Uma exceção apareceu no saprolito do perfil $\mathrm{P} 1$, o que pode ser relacionado a maior quantidade de minerais primários como micas e feldspatos. Para o K, os maiores teores ocorrem nos solos do topo da colina e no perfil P1, na planície hidromórfica. Este elemento possivelmente é proveniente do intemperismo de feldspatos, como ortoclásio e microclínio.

\subsection{Composição mineralógica}

\subsubsection{Mineralogia dos grãos de cascalho e areia fina}

$\mathrm{O}$ quartzo é o mineral mais abundante no esqueleto do solo e os feldspatos e micas ocorrem em quantidades crescentes em profundidade. (Tabela 5). A quantidade destes minerais é normalmente maior na fração cascalho em relação `a areia fina, evidenciando uma maior resistência ao intemperismo das partículas de maior tamanho.

Os feldspatos e micas são mais abundantes na alterita do topo da colina em relação àquelas da borda da colina e da planície hidromórfica. A menor quantidade destes minerais observada na planície e na borda da colina pode ser indicativo da maior intensidade de intemperismo nestes ambientes. 
Tabela 5. Freqüência (\%) de minerais presentes na fração cascalho e areia fina nas seqüências estudadas.

\begin{tabular}{|c|c|c|c|c|c|c|c|}
\hline \multirow[t]{2}{*}{ Horiz. } & \multirow{2}{*}{$\begin{array}{l}\text { Prof. } \\
(\mathrm{cm})\end{array}$} & \multicolumn{3}{|c|}{ Cascalho $(>2 \mathrm{~mm})$} & \multicolumn{3}{|c|}{ Areia fina $(0,1-0,25 \mathrm{~mm})$} \\
\hline & & Quartzo & Feldspatos & Mica & Quartzo & Feldspatos & Mica \\
\hline \multicolumn{8}{|c|}{$\mathrm{C} 1:$ topo da colina } \\
\hline A & $0-2$ & 93,6 & 3,7 & 0,0 & 98,5 & 0,5 & 1,0 \\
\hline BA & $10-20$ & 94,5 & 4,1 & 1,4 & 96,9 & 1,1 & 2,0 \\
\hline $\mathrm{Bw}$ & $50-70$ & 91,9 & 6,1 & 2,0 & 95,5 & 2,5 & 2,0 \\
\hline $\mathrm{BC}$ & $140-160$ & 80,7 & 17,2 & 2,1 & 89,7 & 4,6 & 5,7 \\
\hline $\mathrm{C}$ & $200-220$ & 75,0 & 21,1 & 3,9 & 61,6 & 12,8 & 25,6 \\
\hline \multicolumn{8}{|c|}{ TR2/I: borda da colina } \\
\hline A & $0-3$ & 97,0 & 3,0 & 0,0 & 99,0 & 1,0 & 0,0 \\
\hline BA & $10-20$ & 95,5 & 3,0 & 1,5 & 97,4 & 2,0 & 0,6 \\
\hline Bw1 & $50-60$ & 96,4 & 3,6 & 0,0 & 97,5 & 1,5 & 1,0 \\
\hline Bw2 & $85-95$ & 96,7 & 2,2 & 1,1 & 97,0 & 2,5 & 0,5 \\
\hline $\mathrm{BCg}$ & $110-120$ & 90,7 & 9,3 & 0,0 & 97,5 & 2,0 & 0,5 \\
\hline $\mathrm{CBg}$ & $125-135$ & 92,6 & 7,4 & 0,0 & 94,0 & 6,0 & 0,0 \\
\hline $\mathrm{Cg}$ & $140-150$ & 85,7 & 14,3 & 0,0 & 91,2 & 8,3 & 0,5 \\
\hline \multicolumn{8}{|c|}{ TR2/II: planície, a $1 \mathrm{~m}$ da borda } \\
\hline A & $0-20$ & 96,0 & 4,0 & 0,0 & 97,5 & 2,0 & 0,5 \\
\hline C & $50-60$ & 95,5 & 3,6 & 0,9 & 96,5 & 3,5 & 0,0 \\
\hline \multicolumn{8}{|c|}{ TR2/III: planicie, a 2,3 m da borda } \\
\hline A & $0-15$ & 87,7 & 12,3 & 0,0 & 89,1 & 9,3 & 1,6 \\
\hline $\mathrm{C}$ & $55-65$ & 62,7 & 34,3 & 2,9 & 73,7 & 24,0 & 2,3 \\
\hline \multicolumn{8}{|c|}{ TR2/IV: planície, a $5 \mathrm{~m}$ da borda } \\
\hline A & $0-20$ & 95,5 & 4,5 & 0,0 & 97,5 & 2,5 & 0,0 \\
\hline $\mathrm{C}$ & $50-60$ & 93,7 & 6,3 & 0,0 & 97,1 & 2,9 & 0,0 \\
\hline \multicolumn{8}{|c|}{ P1: planície hidromórfica, com Bh endurecido ${ }^{(1)}$} \\
\hline Cop. & $15-0$ & -- & --- & --- & 99,0 & 1,0 & 0,0 \\
\hline A & $0-20$ & $\cdots$ & -- & -- & 99,5 & 0,5 & 0,0 \\
\hline $\mathrm{E}$ & $40-50$ & 100,0 & 0,0 & 0,0 & 98,5 & 1,5 & 0,0 \\
\hline $\mathrm{Bh}$ & $75-85$ & 100,0 & 0,0 & 0,0 & 96,9 & 2,6 & 0,5 \\
\hline $\mathrm{BhC}$ & $110-120$ & 97,6 & 2,4 & 0,0 & 89,8 & 6,6 & 3,6 \\
\hline $\mathrm{Cgr}$ & $140-150$ & 92,0 & 5,7 & 2,3 & 78,2 & 13,4 & 8,4 \\
\hline
\end{tabular}

1. Presença de turmalina (dravita) na fração cascalho, com teor crescente em profundidade, atingindo cerca de $15 \%$ no horizonte Cgr. (---) = não analisado.

Na planície hidromórfica, na porção oeste da seqüência, onde se distribui o horizonte $\mathrm{Bh}$ endurecido, foi identificada uma variedade magnesiana de turmalina, identificada como dravita por difratometria de raio $\mathrm{X}$, compondo pequena quantidade da fração cascalho em subsuperficie. A ocorrência deste mineral, que ocorre como acessório no granito é uma evidência de variação localizada na composição litológica. 


\subsubsection{Mineralogia da fração silte}

A constituição mineralógica da fração silte é representada por minerais primários, como quartzo e feldspatos, e, por minerais secundários, tais como gibbsita, caulinita e interestratificados vermiculita-ilita, presentes em algumas amostras (Tabela 6 e Anexo D).

O quartzo é o mineral dominante na fração silte em todos os materiais, com picos característicos em 0,426 nm e 0,334 nm, e com reflexos secundários em 0,$246 ; 0,228 ; 0,224 ; 0,213 ; 0,198 ; 0,182$ e $0,167 \mathrm{~nm}$. O feldspato identificado foi o microclínio, apresentando picos em $0,347 \mathrm{~nm}$ e $0,325 \mathrm{~nm}$. Este mineral mostra picos mais evidentes na base dos perfis, que diminuem de intensidade nos horizontes superficiais, indicando progressivo intemperismo. Os plagioclásios, identificados pela microscopia ótica como componentes da rocha, não são constatados nos difratogramas, o que sugere rápido intemperismo, que ocorre mais intensamente na base do perfil.

Entre os minerais secundários, a gibbsita aparece na maioria das amostras analisadas (picos em 0,485 nm e 0,437 nm), com exceção daquelas provenientes da planície hidromórfica, nas áreas de ocorrência do Bh solto, onde se verifica caulinita em maior intensidade (reflexos a $0,72 \mathrm{~nm}$ e $0,356 \mathrm{~nm}$ ). A caulinita aparece também na alterita do solo em meia encosta na colina e no saprolito abaixo do Bh endurecido, na planície hidromórfica. O outro mineral secundário foi a vermiculita-mica, caracterizada pelo pico a 1,2 nm. Este mineral é encontrado na fração silte nas alteritas da colina e da planície hidromórfica, sob o horizonte Bh endurecido. Neste solo a vermiculita-mica está associada à mica, com reflexo em $1,0 \mathrm{~nm}$. No outro perfil na planície hidromórfica, $\mathrm{P} 3$, associado ao horizonte $\mathrm{Bh}$ solto as micas ocorrem com pouca intensidade.

A fração silte, a exemplo dos grãos, tem composição mineralógica em estreita relação com o material de origem, especialmente pela presença de feldspatos potássicos, vermiculita-mica e micas, que ocorrem em maior quantidade na base dos perfis. A distribuição destes minerais evidencia uma relação entre latossolos da colina e os solos da planície, apontando para uma evolução pedogenética entre eles. 
Tabela 6. Representação esquemática da composição mineralógica da fração silte dos solos, obtida por difratometria de raio- $X^{(1)}$.

\begin{tabular}{|c|c|c|c|c|c|c|c|}
\hline Horiz. & Prof. $(\mathrm{cm})$ & Quartzo & Feldspatos & Mica & Gibbsita & Caulinita & Verm.-ilita \\
\hline \multicolumn{8}{|c|}{ C1: topo da colina } \\
\hline Bw & $50-70$ & + & + & 0 & + & o & o \\
\hline $\mathrm{BC}$ & $140-160$ & +4 & + & 0 & + & 0 & o \\
\hline C & $200-220$ & +4 & ++ & 0 & + & o & + \\
\hline \multicolumn{8}{|c|}{ C2: meia encosta da colina } \\
\hline BA & $10-20$ & $+1+14$ & + & 0 & + & 0 & 0 \\
\hline $\mathrm{Bw}$ & $80-100$ & 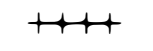 & + & 0 & + & 0 & 0 \\
\hline $\mathrm{BC}$ & $140-160$ & +11 & ++ & o & + & + & + \\
\hline C & $180-200$ & $+1+14$ & ++ & 0 & + & + & + \\
\hline \multicolumn{8}{|c|}{ TR2/I: borda da colina } \\
\hline Bwl & $50-60$ & + & + & 0 & + & 0 & 0 \\
\hline $\mathrm{BCg}$ & $110-120$ & +4 & + & 0 & + & o & $\mathrm{o}$ \\
\hline $\mathrm{Cg}$ & $140-150$ & ++++ & ++ & 0 & - & 0 & 0 \\
\hline \multicolumn{8}{|c|}{ TR3/I: borda da colina } \\
\hline A & $0-10$ & $\ldots$ & + & 0 & + & 0 & 0 \\
\hline $\mathrm{Bi}$ & $40-60$ & $\ldots$ & + & 0 & ++ & o & - \\
\hline $\mathrm{CBg}$ & $100-120$ & ++++ & ++ & 0 & ++ & 0 & + \\
\hline $\mathrm{Cg}$ & $140-160$ & +++ & ++ & 0 & ++ & 0 & + \\
\hline \multicolumn{8}{|c|}{ P1: planície hidromórfica, Bh endurecido } \\
\hline Cop. & $15-0$ & $+1+$ & - & 0 & 0 & 0 & 0 \\
\hline A & $0-20$ & +1 & - & o & 0 & 0 & 0 \\
\hline $\mathrm{Bh}$ & $75-85$ & ++++ & + & o & + & o & 0 \\
\hline $\mathrm{Cgr}$ & $140-150$ & +++ & ++ & - & + & + & + \\
\hline \multicolumn{8}{|c|}{ P3: planície hidromórfica, Bh solto } \\
\hline Cop. & $10-0$ & +1 & 0 & 0 & 0 & 0 & 0 \\
\hline A & $0-10$ & + & 0 & 0 & 0 & 0 & 0 \\
\hline $\mathrm{E} / \mathrm{Bh}$ & $120-130$ & + & 0 & 0 & 0 & o & 0 \\
\hline $\mathrm{Cg}$ & $150-150$ & +++ & + & - & 0 & ++ & 0 \\
\hline
\end{tabular}

\subsubsection{Mineralogia dos óxidos concentrados}

A concentração dos óxidos nos materiais pertencentes a colina permitiu evidenciar predomínio de goethita, com reflexos principais em 0,$498 ; 0,418 ; 0,269$; 0,249 e $0,225 \mathrm{~nm}$ (Anexo D). A hematita associada a goethita foi identificada somente na alterita do topo da colina. Seus picos característicos estão presentes em 0,$367 ; 0,269$; 0,$251 ; 0,220$ e $0,184 \mathrm{~nm}$. $\mathrm{O}$ anatásio $\left(\mathrm{TiO}_{2}\right)$ está presente em pequena quantidade no 
topo e de forma mais evidente na borda da colina. Os reflexos deste mineral ocorrem em 0,$351 ; 0,238$ e $0,189 \mathrm{~nm}$. O quartzo ocorre juntamente com óxidos em todas as amostras.

A mineralogia dos óxidos mostra relação com a coloração dos solos, predominantemente amarelada pela presença de goethita. O material avermelhado em subsuperficie nos solos do topo da colina acusa a presença de hematita. $\mathrm{O}$ anatásio constitui-se um mineral resistente ao intemperismo, cuja presença contribui como fonte de Ti verificada nos extratos do ataque sulfúrico (Tabela 4).

\subsubsection{Mineralogia da fração argila}

Os minerais presentes na fração argila deferrificada nos solos do topo e em meia encosta na colina são principalmente a gibbsita $e$ a caulinita e, secundariamente, o quartzo e os minerais 2:1 (Tabela 7 e Anexo D). A gibbsita mostra reflexos intensos em $0,485 \mathrm{~nm}$ e $0,437 \mathrm{~nm}$, sendo destruída pelo aquecimento a $350{ }^{\circ} \mathrm{C}$. A caulinita é caracterizada pelos picos em $0,715 \mathrm{~nm}$ e em $0,35 \mathrm{~nm}$, os quais são eliminados pelo aquecimento a $550^{\circ} \mathrm{C}$. Destes minerais, a gibbsita mostra-se em maior proporção em relação a caulinita, compondo cerca de $60 \%$ da argila (Figura 20). O quartzo aparece em todos os materiais, com picos em 0,426 nm e 0,333 nm.

Os minerais 2:1 presentes nos solos da porção superior da colina são as vermiculitas, as ilitas, os interestratificados ilita-vermiculita (I-V) e a vermiculita-ilita (V-I), que são mais abundantes em subsuperfície, o que se relaciona com a maior quantidade de minerais primários, como a biotita. As ilitas são caracterizadas pela reflexão em 1,0 nm, não alterada pelos tratamentos. Os interestratificados I-V e V-I têm reflexões em 1,2 nm a temperatura ambiente, contraindo-se a $1,0 \mathrm{~nm}$ pelo aquecimento a $350{ }^{\circ} \mathrm{C}$. O tratamento com etilenoglicol não provoca expansão, mesmo quando fervidos com citrato. As ilitas e os interestratificados são mais abundantes na alterita desses solos. A vermiculita é identificada pelo reflexo a $1,4 \mathrm{~nm}$ não expansível, que se contrai com o aquecimento. Neste mineral constata-se preenchimento parcial com hidróxido de alumínio nas entrecamadas, o que impede sua contração para 1,0 nm quando saturado com potássio. A vermiculita nesses solos está presente somente no conjunto latossólico. 
Tabela 7. Representação esquemática da composição mineralógica da fração argila deferrificada dos solos, identificada por difratometria de raio- $X^{(1)}$.

\begin{tabular}{|c|c|c|c|c|c|c|c|}
\hline Horiz. & Prof. (cm) & Gibbsita & Caulinita & Ilita & $\begin{array}{l}\text { Verm.-Ilita } \\
\text { ou Ilita-V. }\end{array}$ & Vermicul. & Quartzo \\
\hline \multicolumn{8}{|c|}{ C1: topo da colina } \\
\hline A & $0-2$ & +1 & ++ & - & 0 & 0 & - \\
\hline $\mathrm{Bw}$ & $50-70$ & +1 & ++ & o & - & - & - \\
\hline $\mathrm{BC}$ & $140-160$ & +1 & ++ & - & + & 0 & - \\
\hline $\mathrm{C}$ & $200-220$ & HH & ++ & - & ++ & 0 & - \\
\hline \multicolumn{8}{|c|}{ C2: meia encosta da colina } \\
\hline BA & $10-20$ & 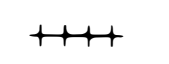 & ++ & o & + & - & - \\
\hline $\mathrm{Bw}$ & $80-100$ & +1 & ++ & o & + & 0 & - \\
\hline $\mathrm{BC}$ & $140-160$ & +4 & ++ & o & ++ & 0 & - \\
\hline $\mathrm{C}$ & $180-200$ & 4 & ++ & o & ++ & 0 & - \\
\hline \multicolumn{8}{|c|}{ TR2/I: borda da colina } \\
\hline A & $0-3$ & +14 & ++ & o & + & - & - \\
\hline Bwl & $50-60$ & +1 & ++ & o & + & + & - \\
\hline Bw2 & $85-95$ & 4 & ++ & o & + & + & - \\
\hline $\mathrm{BCg}$ & $110-120$ & ++++ & ++ & o & + & + & - \\
\hline $\mathrm{CBg}$ & $125-135$ & +4 & ++ & 0 & + & - & - \\
\hline $\mathrm{Cg}$ & $140-150$ & +1 & ++ & o & + & - & - \\
\hline \multicolumn{8}{|c|}{ TR3/I: borda da colina } \\
\hline A & $0-10$ & ++++ & ++ & 0 & - & - & - \\
\hline $\mathrm{Bi}$ & $40-60$ & $H$ & ++ & 0 & - & - & - \\
\hline $\mathrm{CBg}$ & $100-120$ & +1 & ++ & o & + & 0 & - \\
\hline $\mathrm{Cg}$ & $140-160$ & ++ & + & o & ++ & 0 & - \\
\hline \multicolumn{8}{|c|}{ P1: planície hidromórfica, Bh endurecido } \\
\hline Cop. & $15-0$ & +++ & + & o & 0 & 0 & ++ \\
\hline A & $0-20$ & +++ & - & o & o & 0 & ++ \\
\hline $\mathrm{Bh}$ & $75-85$ & +1 & + & o & 0 & 0 & ++ \\
\hline $\mathrm{Cgr}$ & $140-150$ & +1 & + & - & - & 0 & + \\
\hline \multicolumn{8}{|c|}{ P3: planície hidromórfica, Bh solto } \\
\hline Cop. & $10-0$ & - & ++ & 0 & 0 & 0 & +++ \\
\hline A & $0-10$ & 0 & ++ & 0 & 0 & 0 & +++ \\
\hline $\mathrm{E} / \mathrm{Bh}$ & $120-130$ & - & ++ & o & 0 & 0 & ++ \\
\hline $\mathrm{Cg}$ & $150-150$ & - & +1 & 0 & $\mathrm{o}$ & $\mathrm{o}$ & - \\
\hline
\end{tabular}



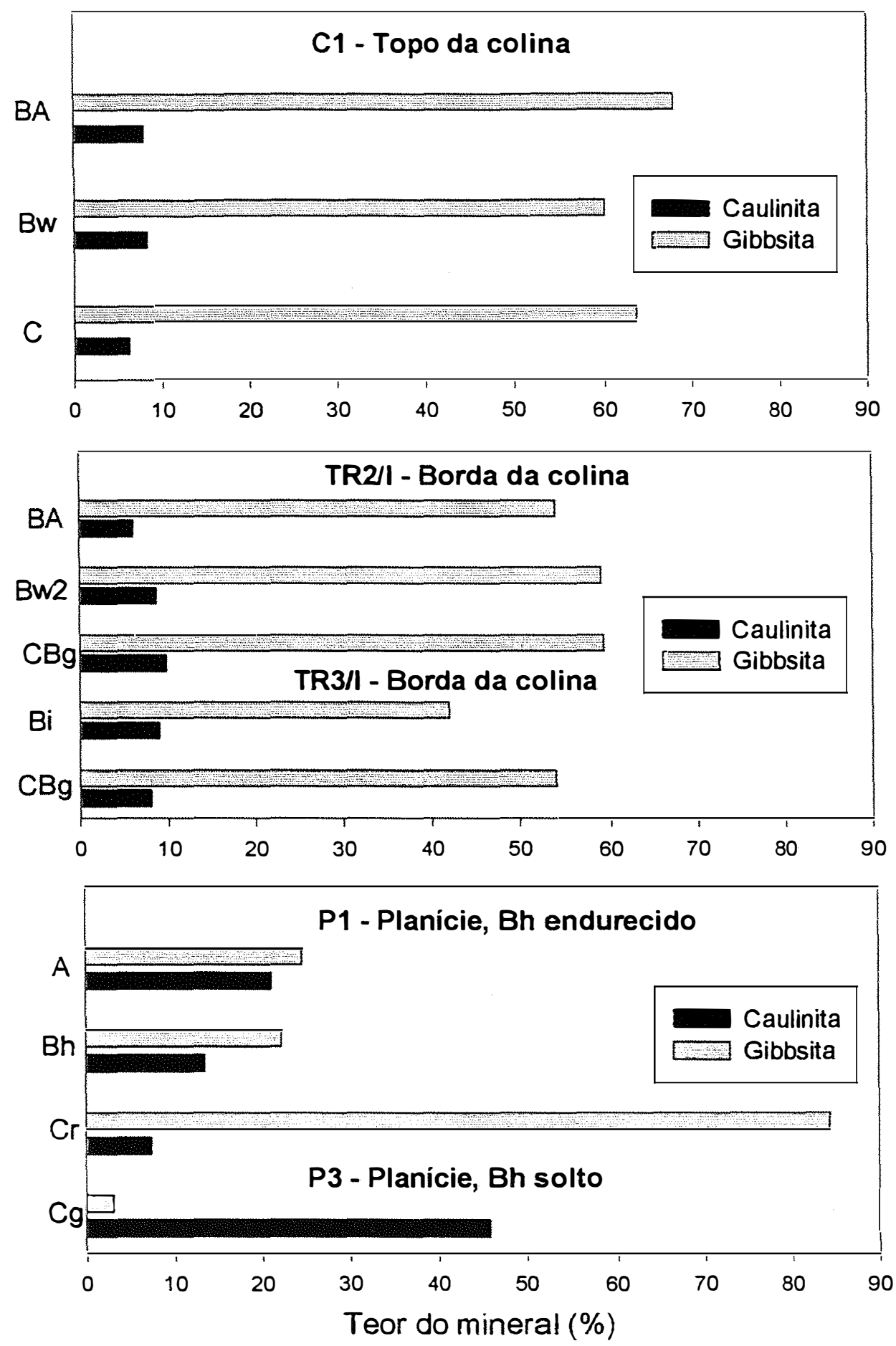

Figura 20 - Teores de caulinita e gibbsita determinados por ATD na fração argila deferrificada. 
Nos solos da borda da colina, os minerais presentes na fração argila deferrificada são semelhantes aos constatados na parte superior da seqüência, identificando-se gibbsita, caulinita, quartzo e minerais $2: 1$, sem a ocorrência de ilitas. A gibbsita é o mineral dominante, ocorrendo em cerca de 40 a $60 \%$ da fração argila deferrificada, enquanto que a caulinita aparece em concentrações próximas de $10 \%$ (Figura 20). Uma diferença é notada em relação a vermiculita, que coexiste com o interestratificado V-I nos materiais com menor quantidade de pseudomorfos de biotita (TR2/I), enquanto que, na porção mais rica em pseudomorfos, somente o interestratificado V-I ocorre (TR3/I). A presença de polímeros de Al nesses minerais é parcial, o que se comprova pela contração a $1,0 \mathrm{~nm}$ quando aquecido a $350^{\circ} \mathrm{C}$ e pela manutenção do mesmo espaçamento nas amostras saturadas com $\mathrm{K} \mathrm{e} \mathrm{Mg}$.

$\mathrm{Na}$ planície hidromórfica, o perfil com horizonte $\mathrm{Bh}$ endurecido mostra quantidades crescentes de gibbsita em profundidade, chegando a cerca de $80 \%$ da argila no saprolito (Horizonte $\mathrm{Cgr}$ ). Os teores de caulinita mostram comportamento contrário à gibbsita, diminuindo no mesmo sentido. O quartzo e os minerais $2: 1$, como as ilitas e ilita-vermiculita estão presentes secundariamente neste solo. Os minerais 2:1 ocorrem somente em subsuperficie, nos horizontes $\mathrm{Bh}$ e $\mathrm{Cr}$. Nos solos com horizonte Bh solto, a caulinita é o mineral secundário predominante, com teor crescente em profundidade.

\subsubsection{Alteração dos minerais primários e constituição do plasma}

A alteração dos minerais primários na colina mostra-se intensa, constatando-se a formação de material rico em alumínio, em proporção superior ao silício nos pseudomorfos de biotita, tanto no conjunto latossólico do topo (Figura 21 a e análise pontual na Figura 23a), quanto na alterita presente na borda da colina (Figura $21 \mathrm{~b}$ e análise na Figura 23b). Esses materiais mostram diferença quanto a quantidade de ferro, que é maior no solo drenado do topo, enquanto que, na alterita sob hidromorfismo,

o ferro encontra-se praticamente ausente. A evolução intempérica dos feldspatos nesses solos mostra resultados semelhantes aos da mica, com formação de plasma com maior quantidade de alumínio em relação ao Si (Figura 21 c e análise na Figura 23c). 
O plasma presente no conjunto latossólico dos solos da colina mostra-se microcristalino, formando uma massa uniforme, sem definição do formato dos cristais (Figuras 22a e 22b). A composição química estimada em vários pontos da amostra evidenciou um predomínio de alumínio em relação ao silício (Figuras $23 \mathrm{~d}$ e $23 \mathrm{e}$, respectivamente). Este resultado é concordante com as determinações da distribuição de gibbsita e caulinita, efetuadas por análise térmica diferencial (Figura 20). Os nódulos presentes na borda da colina (Horizonte $\mathrm{CBg}$ ) mostram-se compostos por macrocristais de gibbsita, formando uma massa compacta (Figura 22c e análise na Figura 23f).

$\mathrm{Na}$ planície hidromórfica, os feldspatos presentes no saprolito ( $\mathrm{Pl}$, horizonte $\mathrm{Cgr}$ ) encontram-se intensamente corroídos (Figura 24a e análise na Figura 25a), apresentando pontuações na superficie compostas por plasma constituído em maior proporção por $\mathrm{Al}$ (Figura 25b). As micas mostram evolução semelhante aos feldspatos (Figura $24 \mathrm{~b}$ e análises nas Figuras $25 \mathrm{c}$ e $25 \mathrm{~d}$ ). A quantidade de ferro presente neste material é pequena, sugerindo um interestratificado vermiculita-ilita. O plasma mineral aí formado é microcristalino, sem forma geométrica aparente. Os materiais orgânicos escuros e presentes na forma de revestimentos em canais de raizes (Figura 24c) apresentam unicamente alumínio na composição (Figura 25e).

No horizonte claro subsuperficial ( $\mathrm{P} 3$, horizonte $\mathrm{Cg}$ ), que se estende em subsuperficie em boa parte da planície hidromórfica, o plasma é microcristalino (Figura 24d), com composição em Al e Si eqüivalente a mineral 1:1 (Figura 25f). Pôde-se constatar em pontos isolados e raros a ocorrência de microfragmentos de mica com estrutura conservada, já alterados a caulinita.

\subsection{Aspectos morfoscópicos dos grãos de quartzo}

\subsubsection{Arredondamento e esfericidade}

A caracterização morfoscópica do arredondamento e esfericidade dos grãos de quartzo evidencia semelhanças entre os solos da colina e da planície. A maioria dos materiais apresenta arredondamento entre 0,2 e 0,4 (formato subangular) e esfericidade entre 0,6 e 0,8 (grãos ovalados) (Figura 26). 

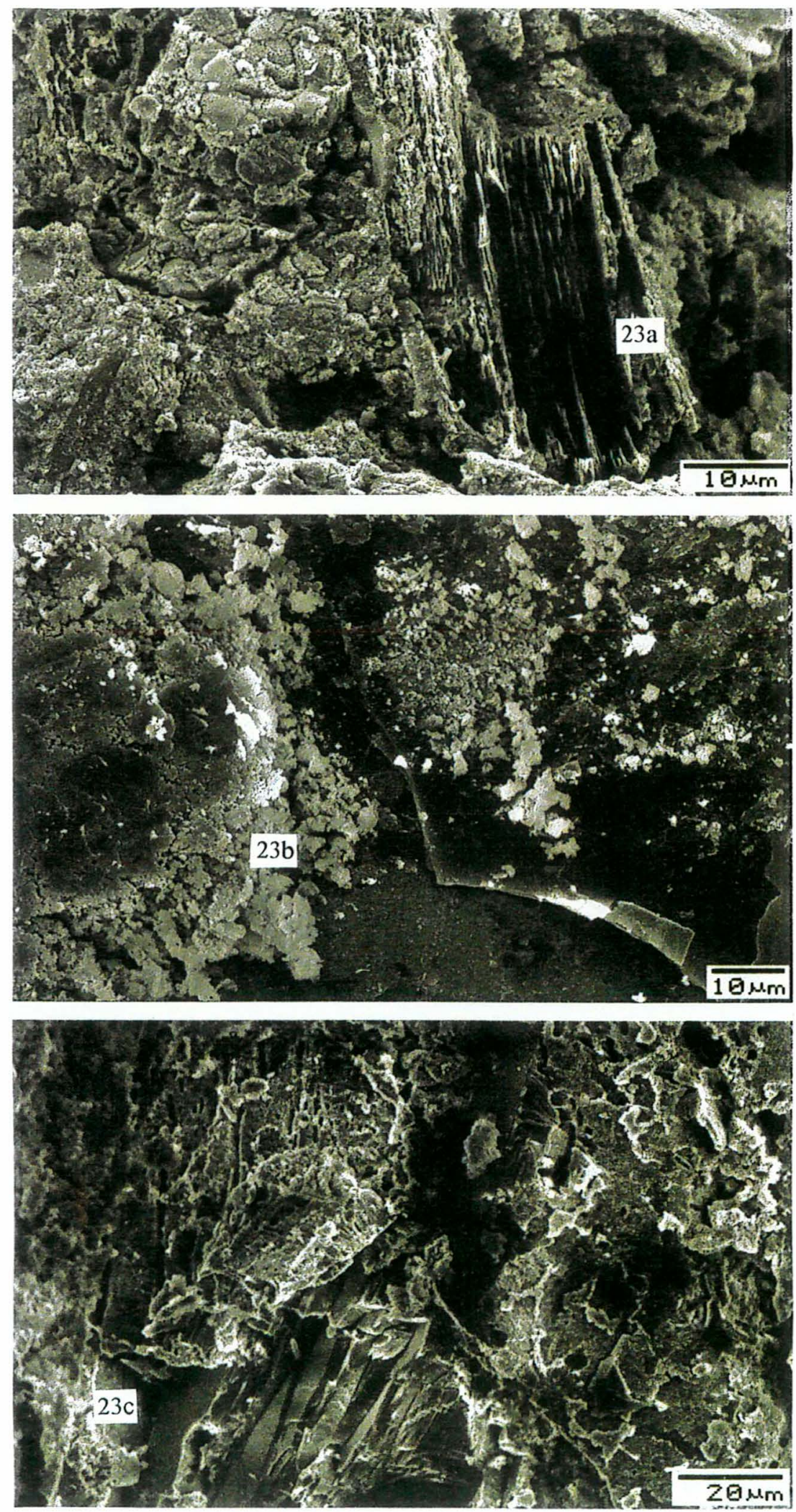

a) Alteração de biotita no horizonte Bw do topo da colina formando material rico em alumínio e ferro (23a)

\section{b) Alteração de} biotita na alterita da borda da colina com material rico em alumínio e pouco ferro (23b)

c) Alteração de feldspato no horizonte Bw da colina formando material rico em alumínio (23c)

Figura 21 - Ilustrações obtidas no MEV da alteração dos minerais na colina. As indicações representam os locais onde foram feitas as análises pontuais (Figura 23). 

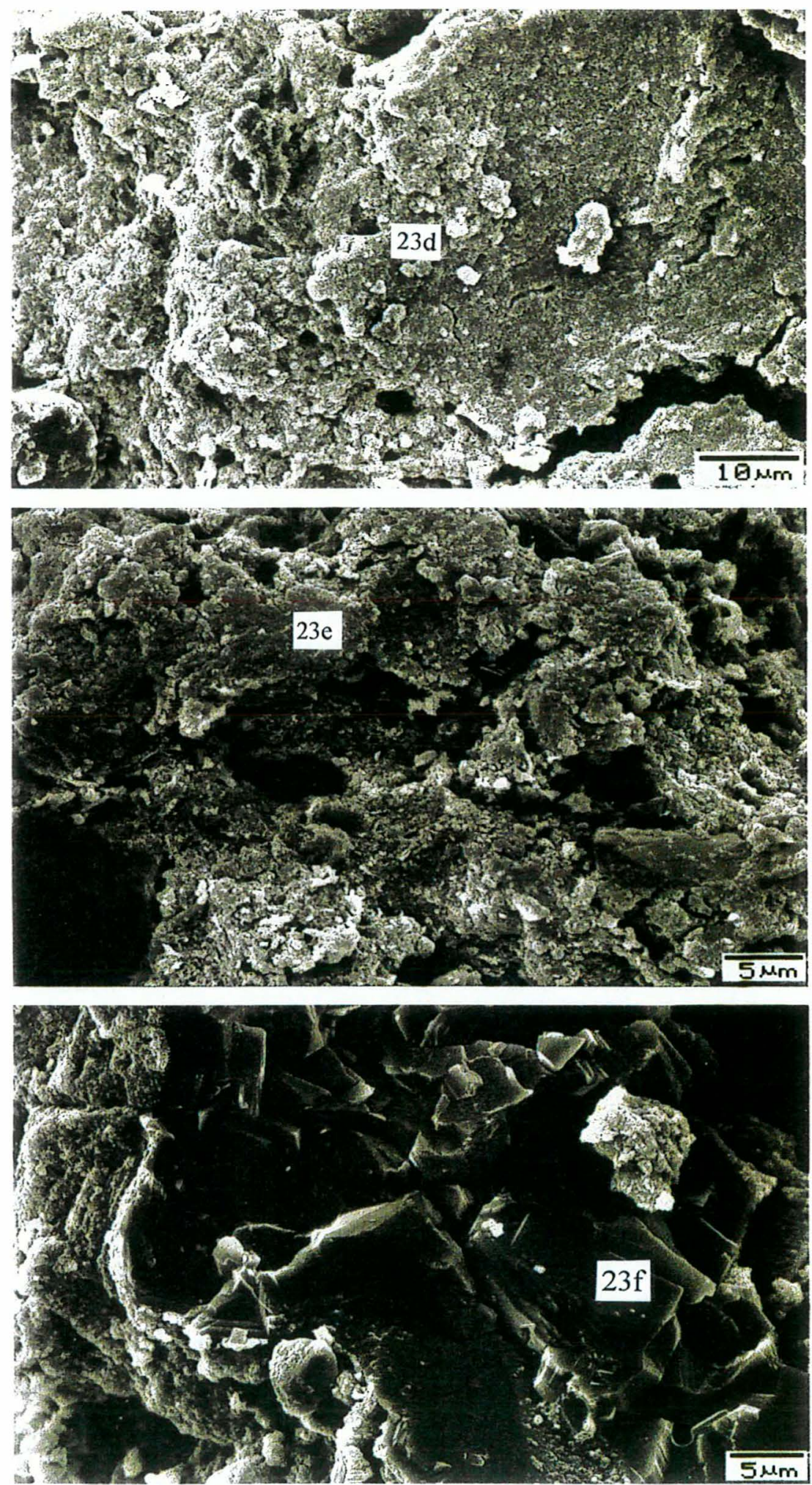

a) Plasma

microcristalino gibbsítico (23d) no horizonte $\mathrm{Bw}$ da colina

b) Plasma microcristalino gibbsítico (23e) no horizonte Bw da borda da colina

c) Macrocristais de gibbsita (23f) em nódulo no horizonte $\mathrm{CBg}$, na borda da colina

Figura 22 - (a,b) Aspecto do plasma argiloso na colina e (b) Macrocristais de gibbsita no horizonte CËg na borda colina. As indicações representam os locais onde foram feitas as análises pontuais (Figura 23). 

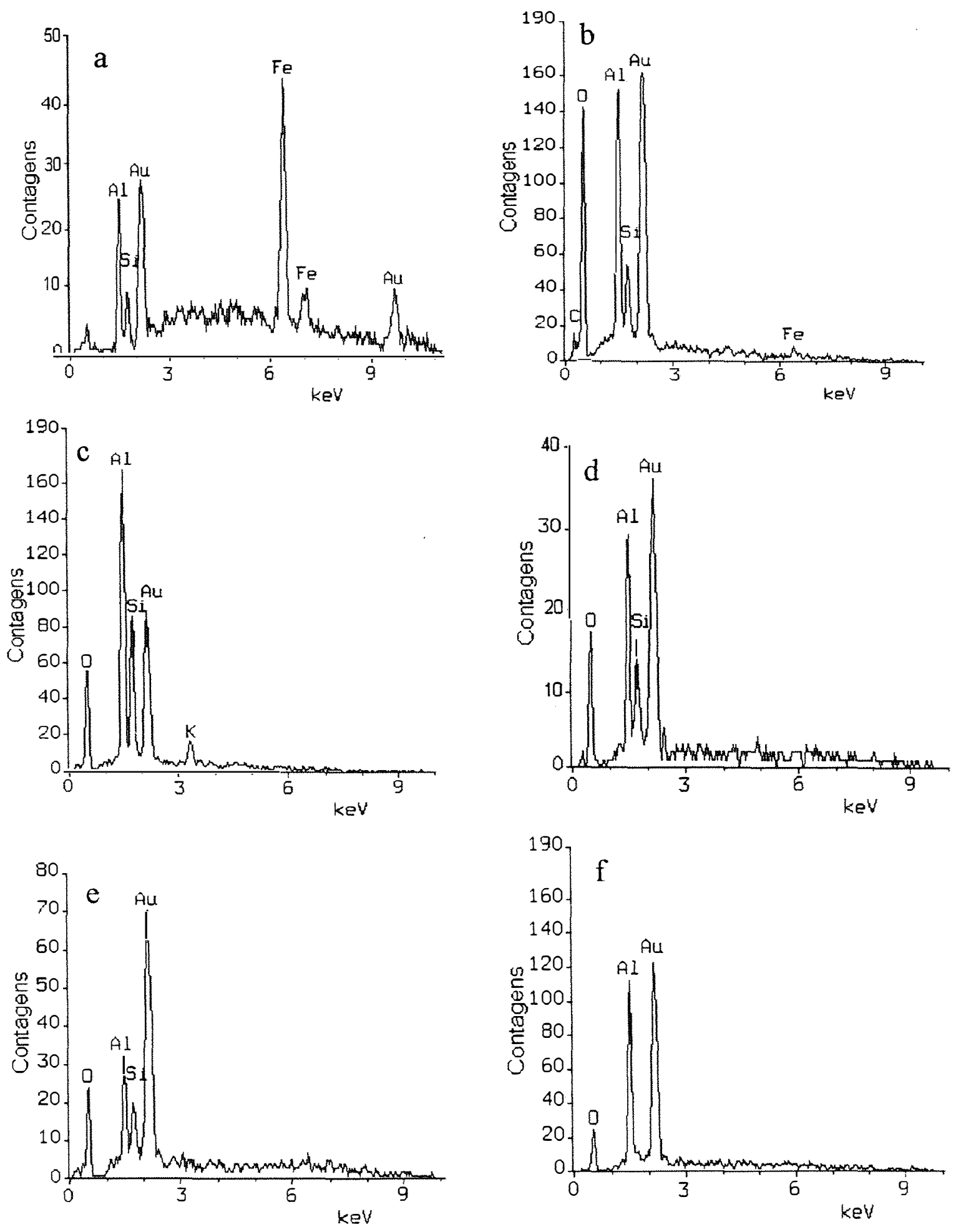

Figura 23 - Análises pontuais por microssonda dos materiais ilustrados nas figuras 21 e 22. 

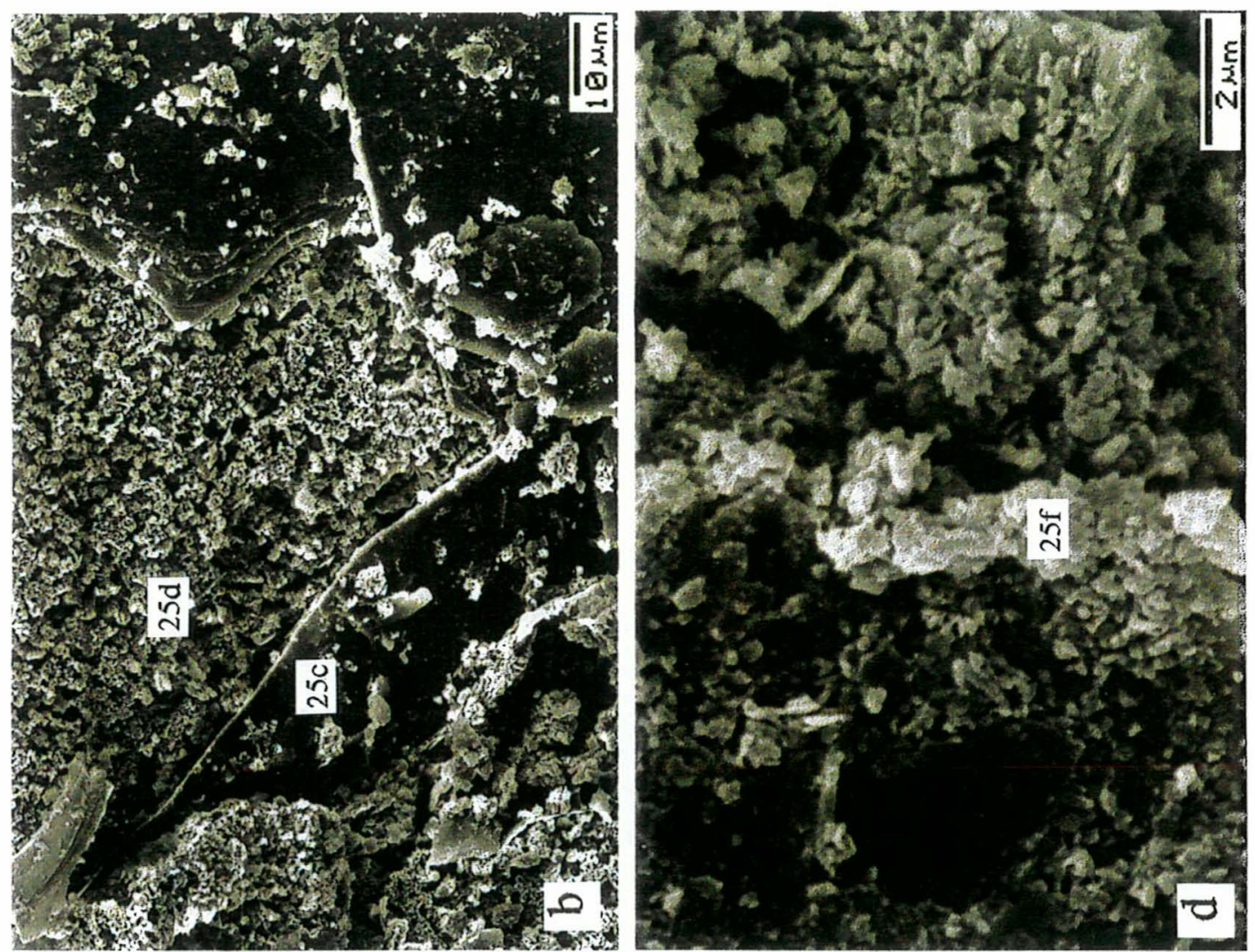

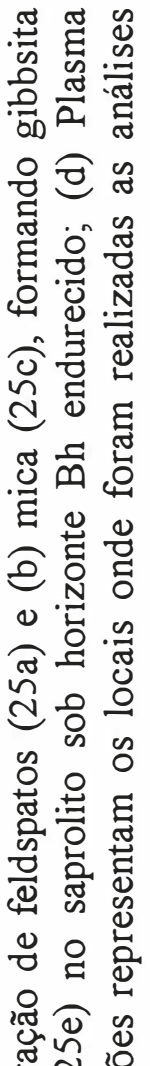
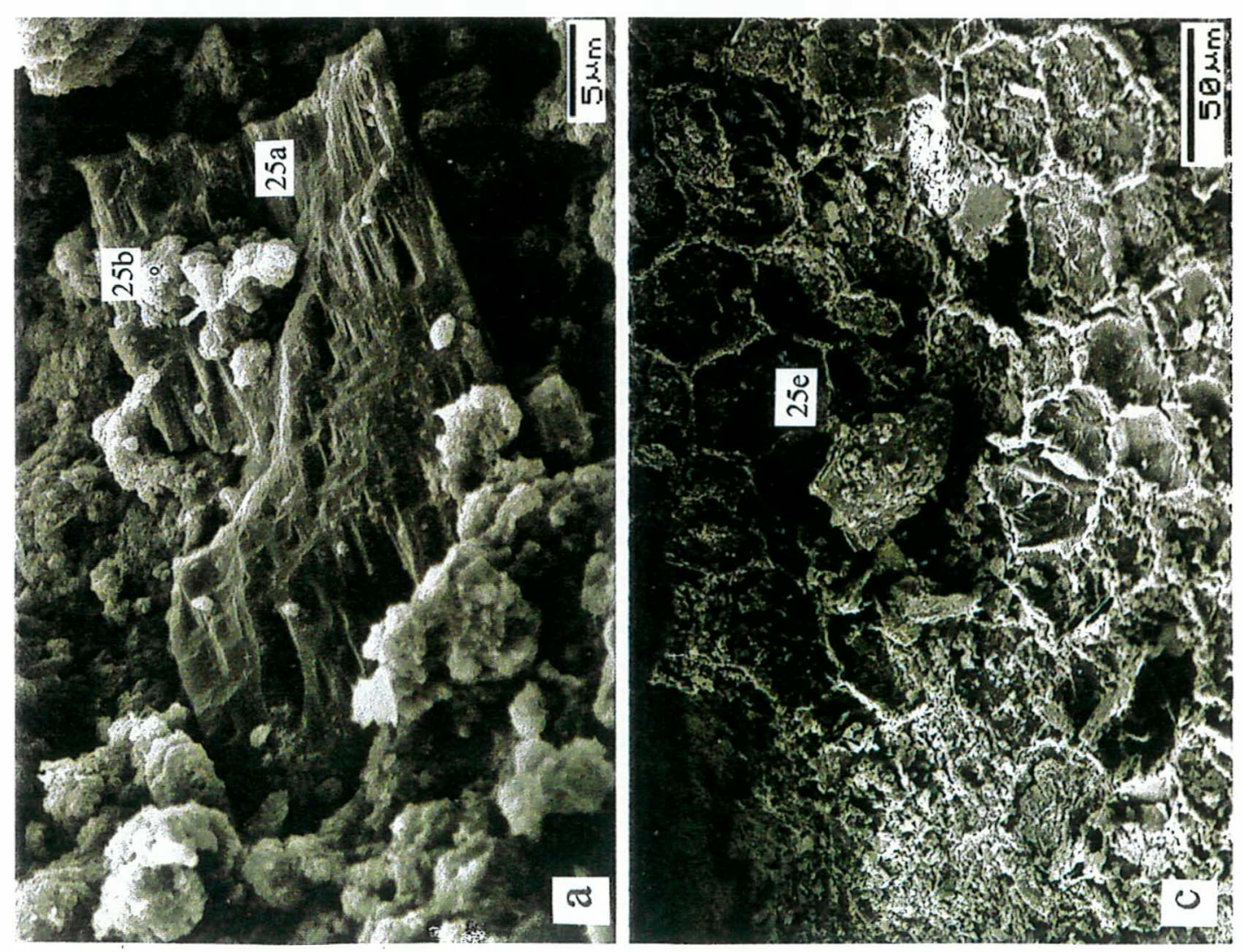

너

学 导

(ङ) हू

ठูं 4

농월

总必

온 엉 도

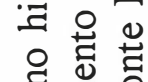

怘. ․ㅗㄹ

유월

กิ

创宛

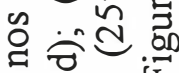

๓

.

志范売

$\sum$ 즁 

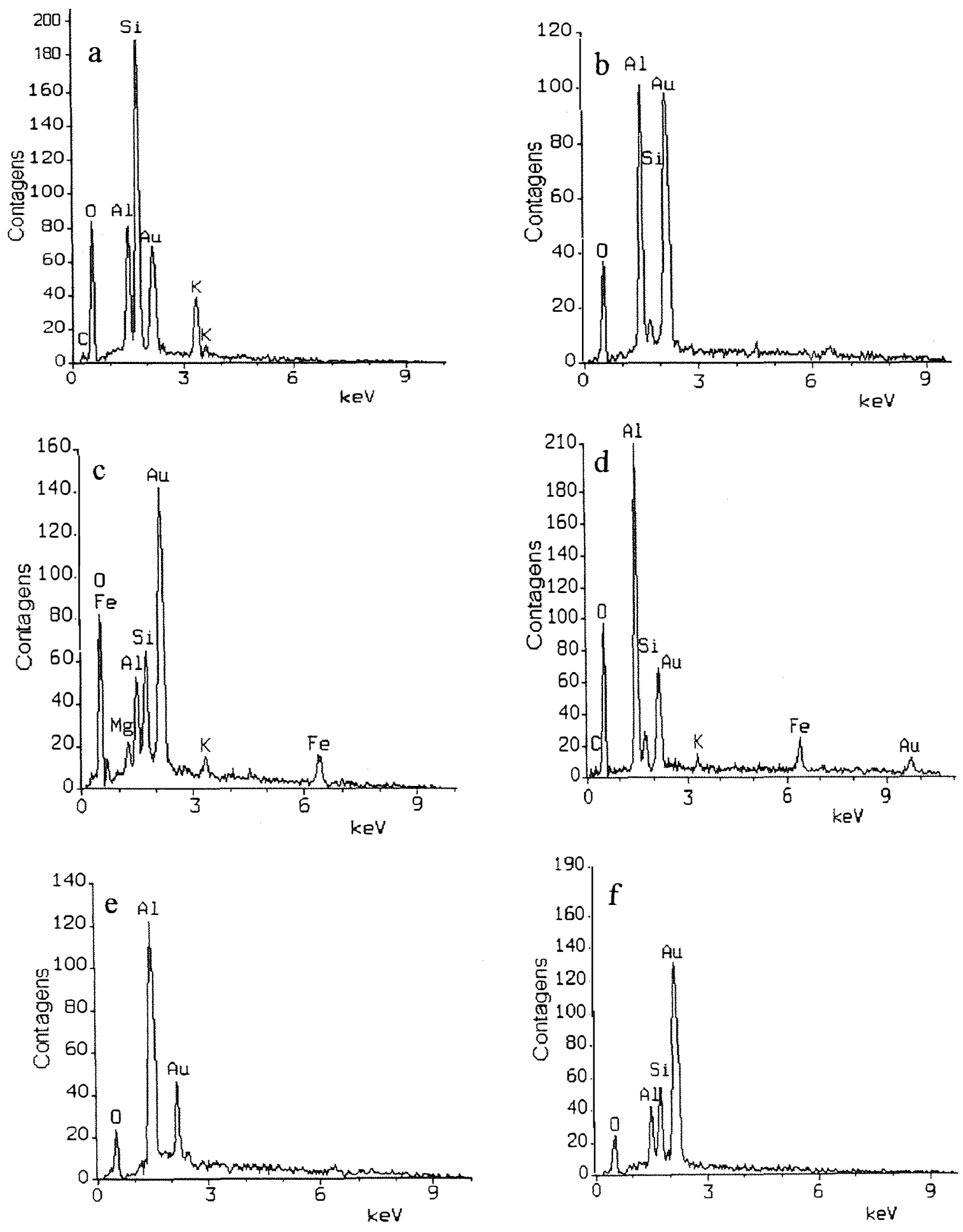

Figura 25 - Análises pontuais por microssonda dos materiais ilustrados na figura 24. 


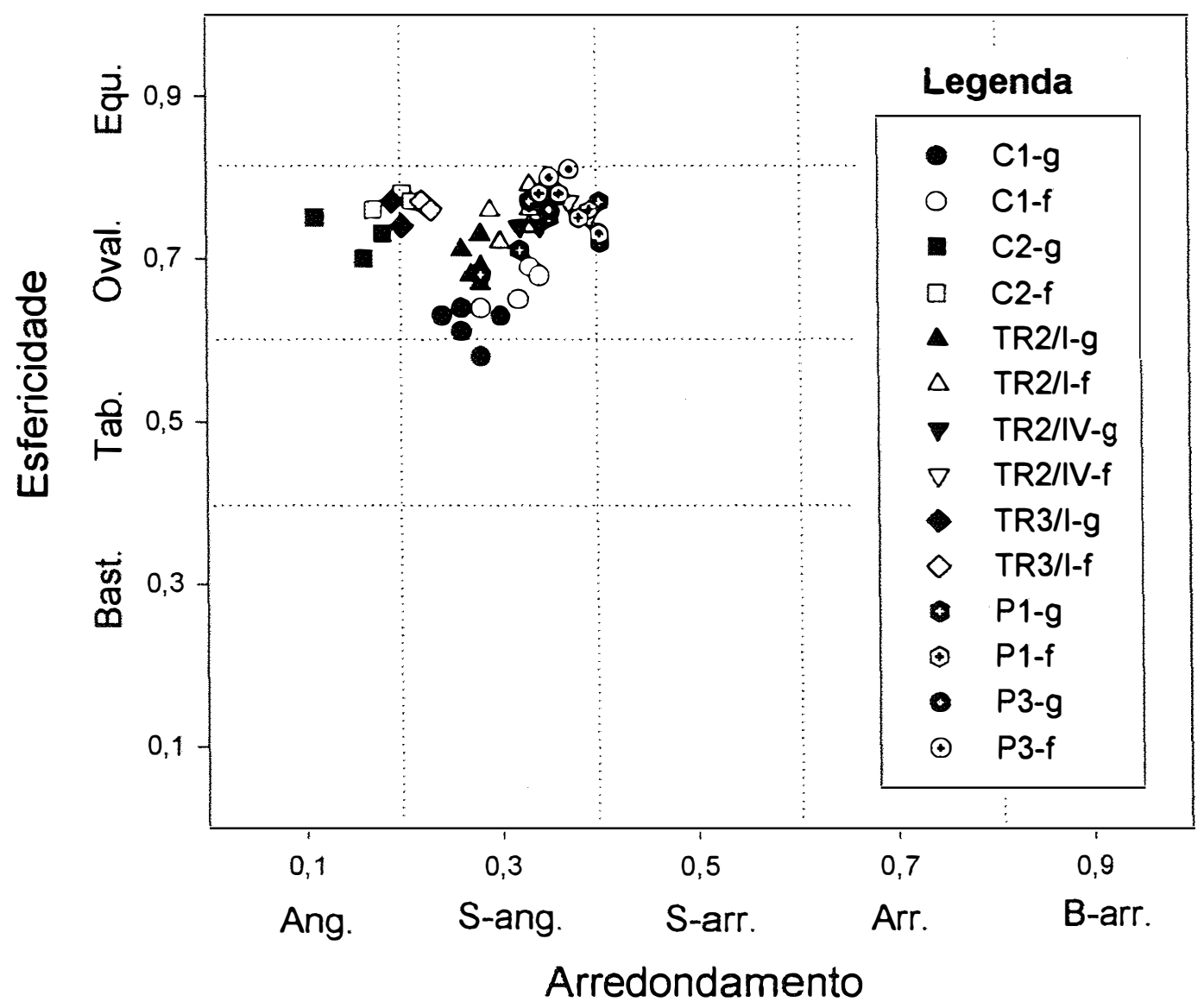

Figura 26 - Valores de arredondamento e esfericidade dos grãos de areia grossa (g) e fina (f) nos materiais analisados na seqüência Latossolo-Podzol, sendo: $\mathrm{Equ}=$ eqüidimensional; Oval $=$ ovalado; $\mathrm{Tab}=$ tabular; $\mathrm{Bast}=$ bastonado $\mathrm{e}$ Ang $=$ angular; $\mathrm{S}$-ang $=$ subangular; $\mathrm{S}$-arr $=$ subarredondado; $\mathrm{Arr}=$ arredondado; $\mathrm{B}$-arr $=$ bem arredondado. 
Uma variação relativamente constante, consistiu na ocorrência de maiores valores de arredondamento e esfericidade na fração areia fina em relação a areia grossa. Isto indica que as partículas mais finas apresentam um formato mais arredondado e eqüidimensional em relação aos grãos maiores. Este resultado pode ser considerado como uma evidência do intemperismo químico intenso que vem agindo sobre os grãos, alterando mais intensamente as partículas de menor tamanho, as quais têm maior superficie específica. A ação do intemperismo é reforçada pelos resultados granulométricos, que evidenciam diminuição gradativa do diâmetro médio das areias em direção a superficie do solo, que ocorre tanto na colina, quanto na planície hidromórfica.

\subsubsection{Aspecto superficial dos grãos de quartzo}

A observação do aspecto superficial dos grãos de quartzo ao microscópio eletrônico de varredura evidenciou figuras de dissolução triangulares, com contornos arredondados (Figuras 27a a 27d). No topo da colina a intensidade de corrosão, ligada a quantidade dessas figuras é pequena na alterita e, crescente em direção a superficie. Este resultado foi concordante com a diminuição no diâmetro médio das partículas no mesmo sentido, o que pode ser atribuído ao intemperismo mais acentuado no topo do perfil. Os materiais com maior quantidade dessas figuras eram localizados no conjunto acinzentado, na borda da colina, e, no conjunto eluvial no plano. Isto indica uma relação entre dissolução do quartzo e presença de um meio hidromórfico. A intensidade de corrosão mostrou variação com o formato dos grãos, sendo mais evidente nas partículas arredondadas em relação às angulosas (Figura $27 \mathrm{~d}$ ).

\subsection{Composição química das águas}

A composição química das águas evidencia teores baixos de bases $\left(\mathrm{Ca}^{2+}\right.$, $\mathrm{Mg}^{2+}, \mathrm{Na}^{+} \mathrm{e}^{+}$) nos diversos pontos analisados, refletindo a pequena reserva desses elementos no solo. Entre as bases, o $\mathrm{K}^{+}$foi a que apresentou as maiores concentrações, $\mathrm{o}$ que mostra relação com a origem granitica dos materiais. Os teores de ânions $\left(\mathrm{SO}_{4}{ }^{2-}\right.$, $\mathrm{NO}_{3}{ }^{-}$e $\mathrm{Cl}^{\circ}$ ) mostram variações grandes entre os locais de coleta, com concentrações 

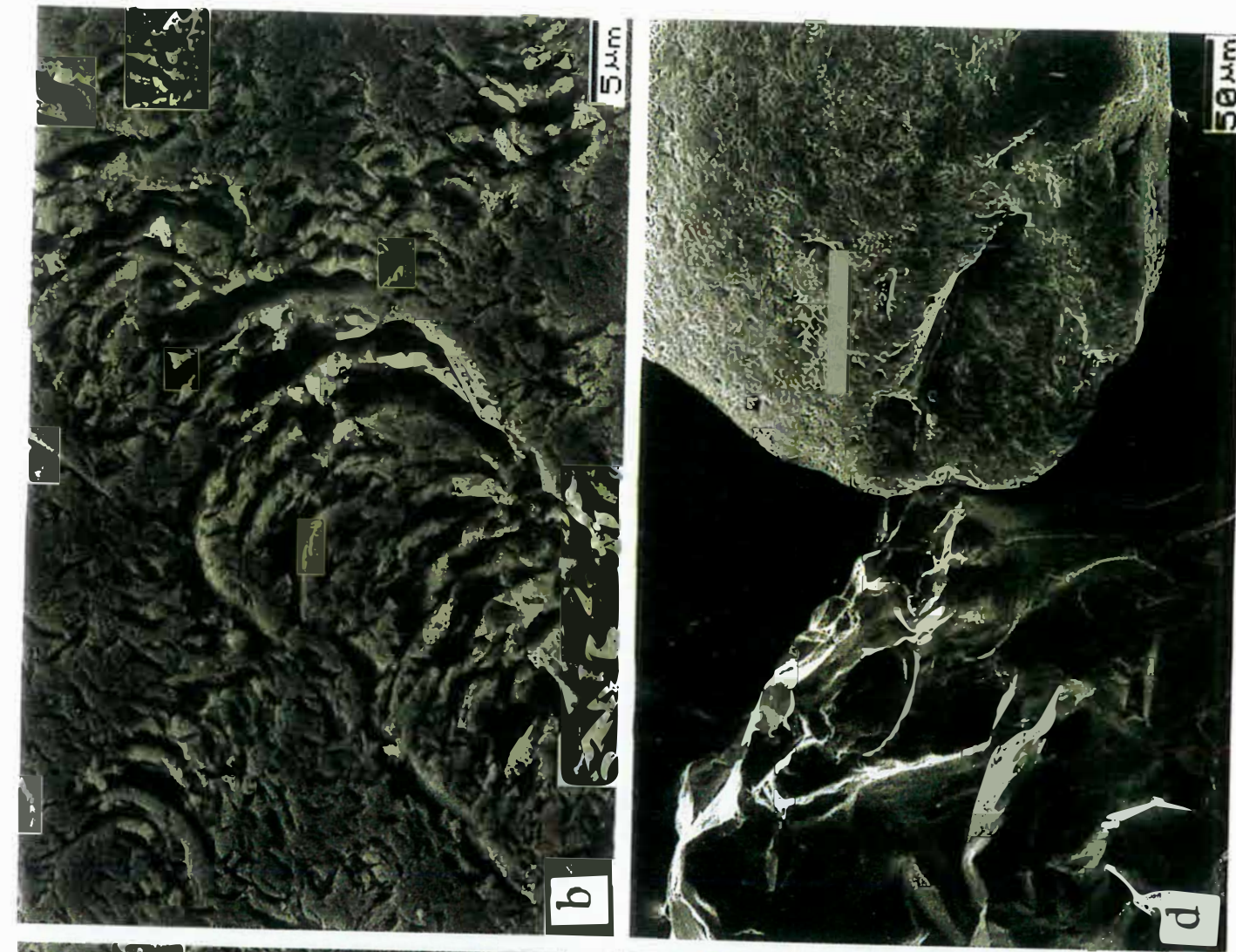

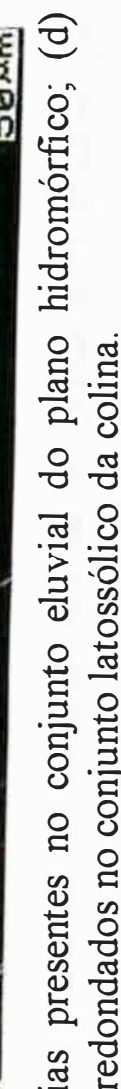
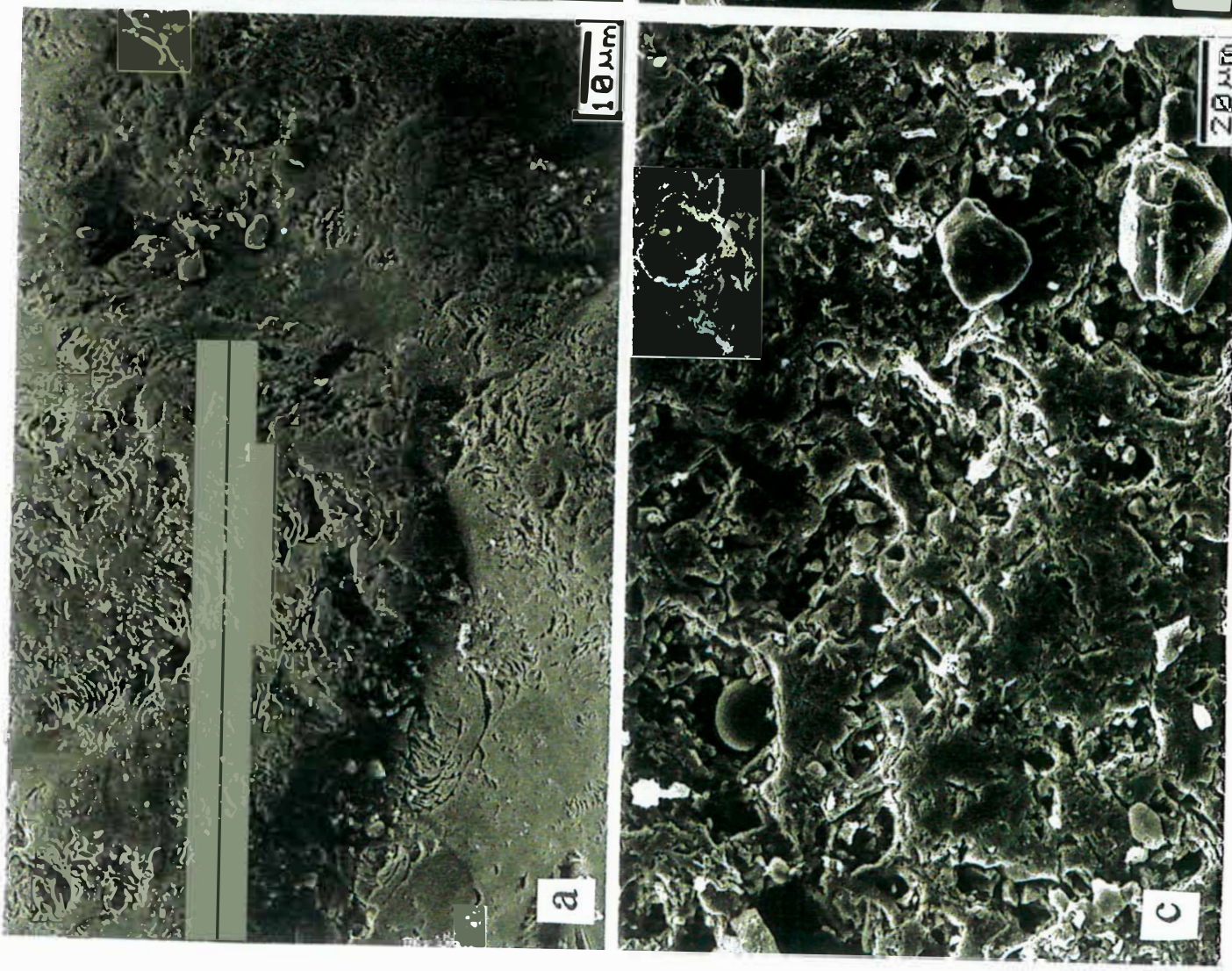

অ

(ง)

ค $\frac{0}{3}$

తీ

oิ

5 b

굥

이 쥴

얼

용

흉

氜

ชิ

क ष्ठ

窎

.

动

I

ก

趈 
mais altas no topo da colina. As soluções presentes no riacho apresentaram menores teores de $\mathrm{Al}^{3+}, \mathrm{Mg}^{2+}, \mathrm{Ca}^{2+}$ e $\mathrm{K}^{+}$em relação às águas coletadas no solo, indicando uma provável reciclagem desses elementos no solo e na matéria orgânica (Tabela 8).

Tabela 8. Composição química das soluções (mg L-1) coletadas nas seqüências de solos.

\begin{tabular}{llllllllll}
\hline Local $^{(1)}$ : data (1999) & $\mathbf{A l}^{3+}$ & $\mathbf{M g}^{2+}$ & $\mathbf{C a}^{2+}$ & $\mathbf{N a}^{+}$ & $\mathbf{K}^{+}$ & $\mathbf{N H}_{\mathbf{4}}{ }^{+}$ & $\mathbf{S O}_{\mathbf{4}}{ }^{2-}$ & $\mathbf{N O}_{\mathbf{3}}{ }^{-}$ & $\mathbf{C l}$ \\
\hline Topo C1: 06/06 & 0,08 & 0,15 & 0,11 & 0,15 & 0,26 & 0,03 & 0,16 & 0,14 & 0,37 \\
Topo C 1: 07/06 & 2,85 & 0,11 & 0,05 & 0,20 & 0,38 & 0,00 & 0,72 & 0,12 & 0,64 \\
Borda: 03/06 & 0,60 & 0,05 & 0,00 & 0,17 & 0,21 & 0,17 & 0,09 & 0,16 & 0,19 \\
Borda: 06/06 & 0,23 & 0,04 & 0,00 & 0,15 & 0,14 & 0,03 & 0,00 & 0,00 & 0,14 \\
Planície P1: 03/06 & 0,54 & 0,08 & 0,16 & 0,10 & 0,91 & 0,00 & 0,15 & 0,00 & 0,18 \\
Planície P1: 06/06 & 0,23 & 0,07 & 0,10 & 0,09 & 0,54 & 0,00 & 0,26 & 0,00 & 0,17 \\
Planície P3: 03/06 & 0,21 & 0,06 & 0,16 & 0,26 & 0,27 & 0,06 & 0,09 & 0,00 & 0,49 \\
Planície P3: 06/06 & 0,17 & 0,03 & 0,02 & 0,16 & 0,13 & 0,01 & 0,03 & 0,00 & 0,19 \\
Riacho: 03/06 & 0,14 & 0,04 & 0,10 & 0,17 & 0,09 & 0,02 & 0,03 & 0,00 & 0,22 \\
Riacho: 06/06 & 0,16 & 0,02 & 0,00 & 0,11 & 0,09 & 0,00 & 0,00 & 0,00 & 0,16 \\
\hline
\end{tabular}

1. Localização das amostras: Colina: em C1; Borda: em TR2; Planície-PI, em P1; Planície-P3, a $50 \mathrm{~m}$ de P3; Riacho: nas proximidades de P5.

A concentração de alumínio nas águas mostra dependência com o tipo de ambiente pedológico. No topo da colina a variação diária foi muito alta, impedindo sua interpretação. As maiores concentrações foram obtidas na borda da colina e na planície hidromórfica, nas proximidades da borda da colina (P1), diminuindo em direção ao eixo de drenagem. Este resultado pode ser relacionado com o funcionamento atual dos solos, apontando para um maior liberação de alumínio na periferia da colina.

A quantidade de $\mathrm{Al}^{3+}$ mobilizado nessas águas varia entre 0,34 e $0,88 \mathrm{~g}$ $\mathrm{m}^{-2}$ ano ${ }^{-1}$ no plano próximo da borda da colina, caindo para $0,22 \mathrm{~g} \mathrm{~m}^{-2}$ ano $\mathrm{o}^{-1}$ no riacho. Essas quantidades de $\mathrm{Al}^{3+}$ indicam solubilização de gibbsita da ordem de 1,0 a $2,5 \mathrm{~g} \mathrm{~m}^{-2}$ $\mathrm{ano}^{-1}$, que seria redistribuído no local, provavelmente nas camadas subsuperficiais do solo. A quantidade de $\mathrm{Al}^{3+}$ removida pelo riacho eqüivale a $0,6 \mathrm{~g} \mathrm{~m}^{-2}$ ano $^{-1}$ de gibbsita solubilizada. 


\subsection{Classificação dos solos}

Os perfis de solo descritos na porção superior da seqüência e um dos perfis presente no barranco (TR2/I), na borda da colina, foram classificados como LATOSSOLOS AMARELOS Distróficos. Nas outras porções estudadas na borda da colina foram identificados um GLEISSOLO HÁPLICO (TR3/I) e um NEOSSOLO LITÓLICO (TR1/I). Na planície hidromórfica, na porção próxima à colina, os solos foram enquadrados como NEOSSOLO LITÓLICO (TR1/I) e NEOSSOLOS QUARTZARÊNICOS Hidromórficos (TR2 e TR3). Na maior parte da área, nas porções mais afastadas da colina, os perfis foram classificados como ESPODOSSOLOS CÁRBICOS Hidromórficos. A classificação detalhada dos solos encontra-se no Anexo A. 


\section{DISCUSSÃO}

\subsection{Pedogênese nos solos da colina}

Numa primeira etapa do estudo que visa compreender a evolução dos solos na colina, buscou-se conhecer a existência da relação entre a cobertura pedológica e o material de origem subjacente.

Os principais indicativos do desenvolvimento autóctone dos solos da colina são os seguintes: diferenciação gradual na coloração e estrutura, indicando relação vertical entre os conjuntos pedológicos; diminuição progressiva no diâmetro médio das areias e aumento na relação areia fina/areia total em direção ao topo dos perfis; esfericidade e arredondamento dos grãos de quartzo uniforme; e composição mineralógica dependente dos constituintes do granito, com modificações progressivas na quantidade de micas e feldspatos no esqueleto.

A formação desses solos é marcada pela alteração dos minerais primários dando origem a um plasma de constituição gibbsítica e caulinítica e pelo desenvolvimento da estrutura granular muito pequena. A formação da estrutura microgranular parece estar ligada à atividade animal, de cupins e formigas, que moldam porções do solo durante a construção dos ninhos e demais bioestruturas, produzindo microagregados ovais, normalmente com presença de esqueleto triado fino. Estas estruturas são observadas no interior de pedotúbulos, algumas vezes com os contornos nítidos e, em outros casos, com transição difusa para domínios maciços. O papel da fauna do solo, em especial a ação dos cupins na gênese da estrutura dos latossolos foi demonstrada por alguns autores (Eschenbrenner, 1986; Miklós, 1992). O desenvolvimento desses microagregados pode ainda estar relacionado à ação de 
óxidos de ferro, como relatam Stoops \& Buol (1985) e Resende et al. (1995). Esses agregados microgranulares apresentam coloração e aspecto semelhantes ao fundo matricial adjacente, o que sugere composição mineralógica semelhante ao conjunto do solo e formação a ele relacionada. A quantidade de agregados microgranulares é maior no horizonte $\mathrm{Bw}$ e diminui gradualmente em direção à base do perfil.

A evolução dos minerais primários nos solos da colina caracteriza um ambiente geoquímico de hidrólise intensa, resultando na alteração rápida de feldspatos e micas, formando gibbsita e caulinita. As micas intemperizam-se em óxidos de ferro, em argilominerais como ilita-vermiculita e vermiculita aluminosa e em caulinita e gibbsita, conforme constatado nos difratogramas e nas observações ao microscópio eletrônico de varredura. O horizonte latossólico desses solos é pouco desenvolvido em profundidade, com espessura em torno de $1 \mathrm{~m}$. Em termos mineralógicos verifica-se a presença de minerais alteráveis, como feldspatos e micas em quantidade próxima a $4 \%$ na fração areia fina, que coexistem com grande quantidade de gibbsita na fração argila. Estes solos diferem de outros Latossolos Amarelos da Amazônia brasileira, caracterizados principalmente em áreas sedimentares, e que apresentam mineralogia predominantemente caulinitica (Kitagawa \& Moller, 1979; Lima, 1980).

$\mathrm{O}$ avançado estágio de intemperismo pode ser verificado pela baixa relação silte/argila (Van Wambeke, 1962; Resende et al., 1995) observada nos solos da colina e pelos baixos valores de $\mathrm{Ki}$, que refletem perda intensa de silício, enquadrando o desenvolvimento desses solos no domínio da hidrólise total ou alitização, segundo Melfi \& Pedro (1977).

A agressividade do intemperismo químico se manifesta ainda na superficie corroída dos grãos de quartzo, com desenvolvimento de feições típicas de dissolução, conforme descrito em vários estudos (Eswaran \& Stoops, 1979; Asumadu et al., 1987; Fritsch, 1988). Essa alteração intensa permite explicar a diminuição no diâmetro médio das areias em direção à superficie, como também o maior arredondamento e esfericidade observados na areia fina em relação a areia grossa. 


\subsection{Relações entre os domínios latossólico e hidromórfico}

Da mesma forma que se procedeu na porção superior das seqüências, buscou-se evidências da filiação dos solos na periferia da colina e na planície hidromórfica. Neste caso, os indicativos da autoctonia dos materiais são os seguintes: a) presença de matacões de granito intercalados com o material arenoso na borda da colina. Nas fendas entre os blocos de rocha, observa-se acúmulo de cascalho e fragmentos de rocha, passando progressivamente para areia branca; b) presença comum de litorrelíquias no topo do horizonte $\mathrm{Bh}$ endurecido; c) uniformidade vertical no arredondamento e esfericidade dos grãos de quartzo (similaridade morfológica entre os grãos da alterita e do solo) e ausência de indícios de abrasão mecânica que pudessem sugerir contribuição de processos sedimentares; d) variações progressivas no diâmetro médio das areias e na relação entre areia fina e areia total; e) ausência de estrutura sedimentar nas areias brancas; e f) aprofundamento progressivo da rocha a medida que se distancia da colina, inicialmente com disposição simétrica de areia branca sobre a rocha, numa faixa circundando a colina. A partir daí, nas porções mais afastadas da colina, nota-se a presença do saprolito de granito ou material arenoargiloso claro, os quais são cobertos pela camada de areia branca.

A partir dos indicativos da filiação dos materiais do solo, foram estudadas as variações laterais na cobertura pedológica, buscando-se evidências da relação genética lateral entre o Latossolo e o Podzol Hidromórfico. Uma dessas relações foi constatada na colina, onde observa-se distribuição simétrica do amarelecimento dos solos em profundidade e lateralmente em direção a parte inferior das seqüências (Figura 9). Esse processo se identifica também no exame micromorfológico nas camadas subsuperficiais avermelhadas presentes na porção superior das vertentes (Figura 10d). Nas proximidades da borda da colina, o material amarelado torna-se progressivamente acinzentado, pela ação da gleização subsuperficial encontrada nesta zona. A modificação na coloração é acompanhada pela diferenciação textural, partindo-se da alterita relativamente argilosa na colina, que torna-se gradualmente arenosa nas proximidades da borda da colina, chegando a 
camada de areia branca disposta sobre a rocha no plano arenoso adjacente. Essas variações na coloração e textura são coincidentes com a disposição vertical dos materiais nos perfis localizados na borda da colina. Neste caso, verifica-se a passagem gradativa do conjunto superior amarelado e argilo-arenoso, passando para uma porção intermediária mosqueada e, por fim, para a alterita acinzentada e arenosa sob hidromorfismo permanente. $\mathrm{O}$ exame micromorfológico destacou a alteração da estrutura latossólica, passando para um material maciço, com progressiva perda de plasma em direção à alterita, constatada em domínios com areia branca (Figura 28).

O desenvolvimento das zonas arenosas abaixo do conjunto latossólico na borda da colina é progressivo, inicialmente em domínios milimétricos descoloridos, que surgem no material mosqueado. Em profundidade essas porções arenosas tornam-se maiores e coalescem, passando gradativamente para a alterita cinzenta arenosa, que apresenta somente algumas zonas ainda providas de plasma (Figura 29). Esta disposição em domínios que progressivamente formam o conjunto arenoso em subsuperficie, abaixo do material amarelo é uma evidência do desenvolvimento "in situ" das areias, em relação com a alterita granítica da colina.

A zona de contato colina-plano, com contornos muito recortados é uma organização que sugere a existência de relação entre os domínios latossólico e hidromórfico. Isto é reforçado ainda pela ocorrência, nas proximidades da borda da colina, de uma depressão fechada e pela formação dos montículos arredondados, compostos por solo amarelado, que se encontram muitas vezes parcialmente circundados pelo material arenoso.

A distribuição dos conjuntos pedológicos na planície hidromórfica ocorre de forma simétrica em relação à colina. As areias brancas estão dispostas diretamente sobre a rocha pouco profunda, formando uma faixa em torno da colina. $\mathrm{O}$ aprofundamento da rocha nas porções mais afastadas da colina coincide com o surgimento do horizonte $\mathrm{Bh}$, que ocorre sobre o saprolito ou sobre o conjunto claro areno-argiloso. A camada de areia branca acompanha esta diferenciação, tornando-se mais espessa conforme se afasta da colina. 

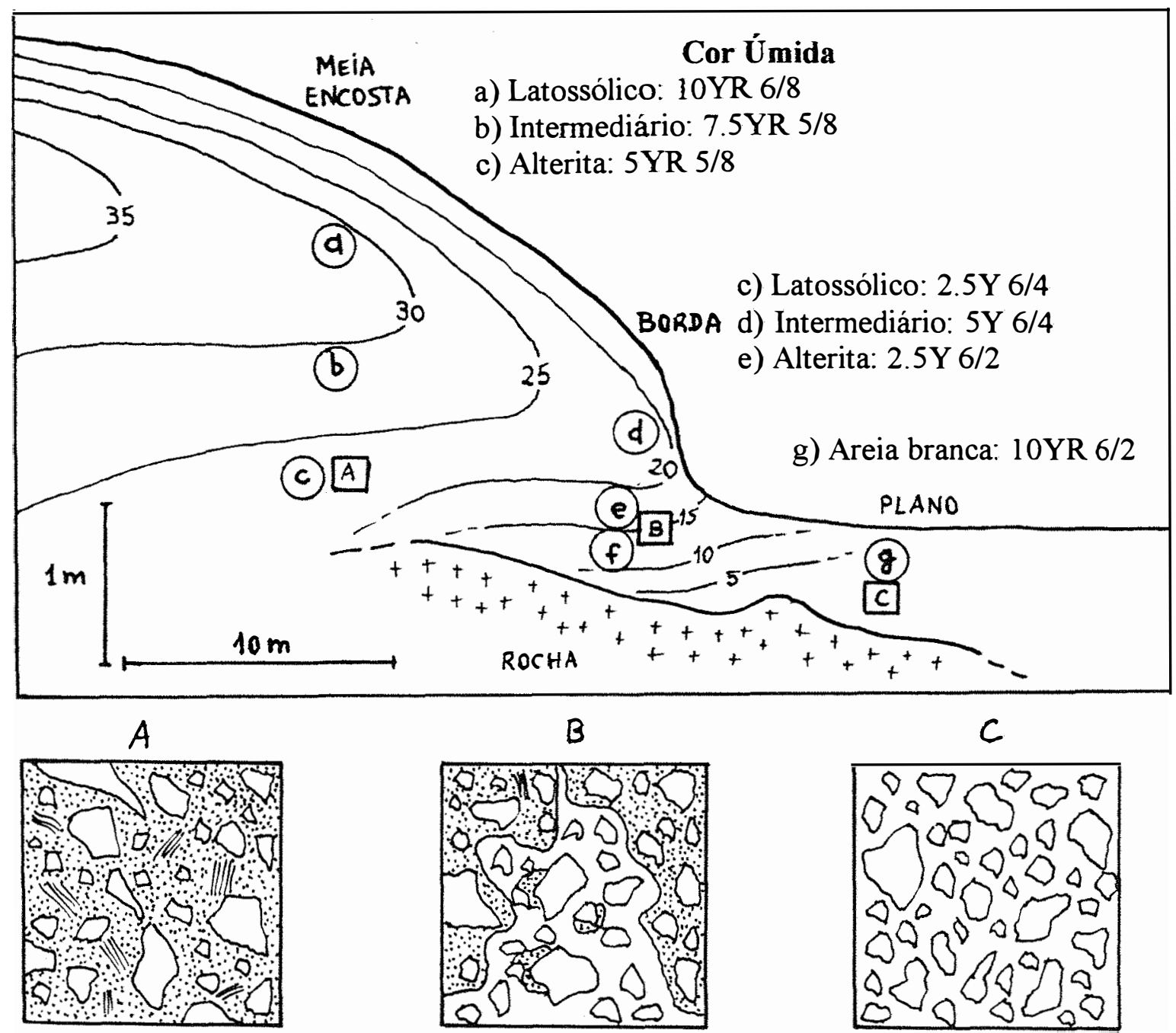

B

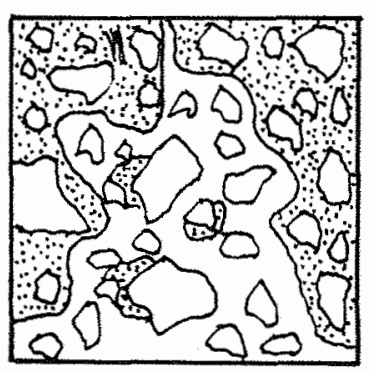

Alterita cinza, intertéxtica a aglomeroplásmica, domínios de areia lavada (Conforme figura $12 b$ ) c



Areia branca, distribuição relativa granular (Conforme figura 12c, porções arenosas)

Figura 28 - Representação esquemática das variações na coloração, granulometria (isovalores de argila em percentagem) e microestrutura na seqüência Latossolo-Podzol Hidromórfico. 


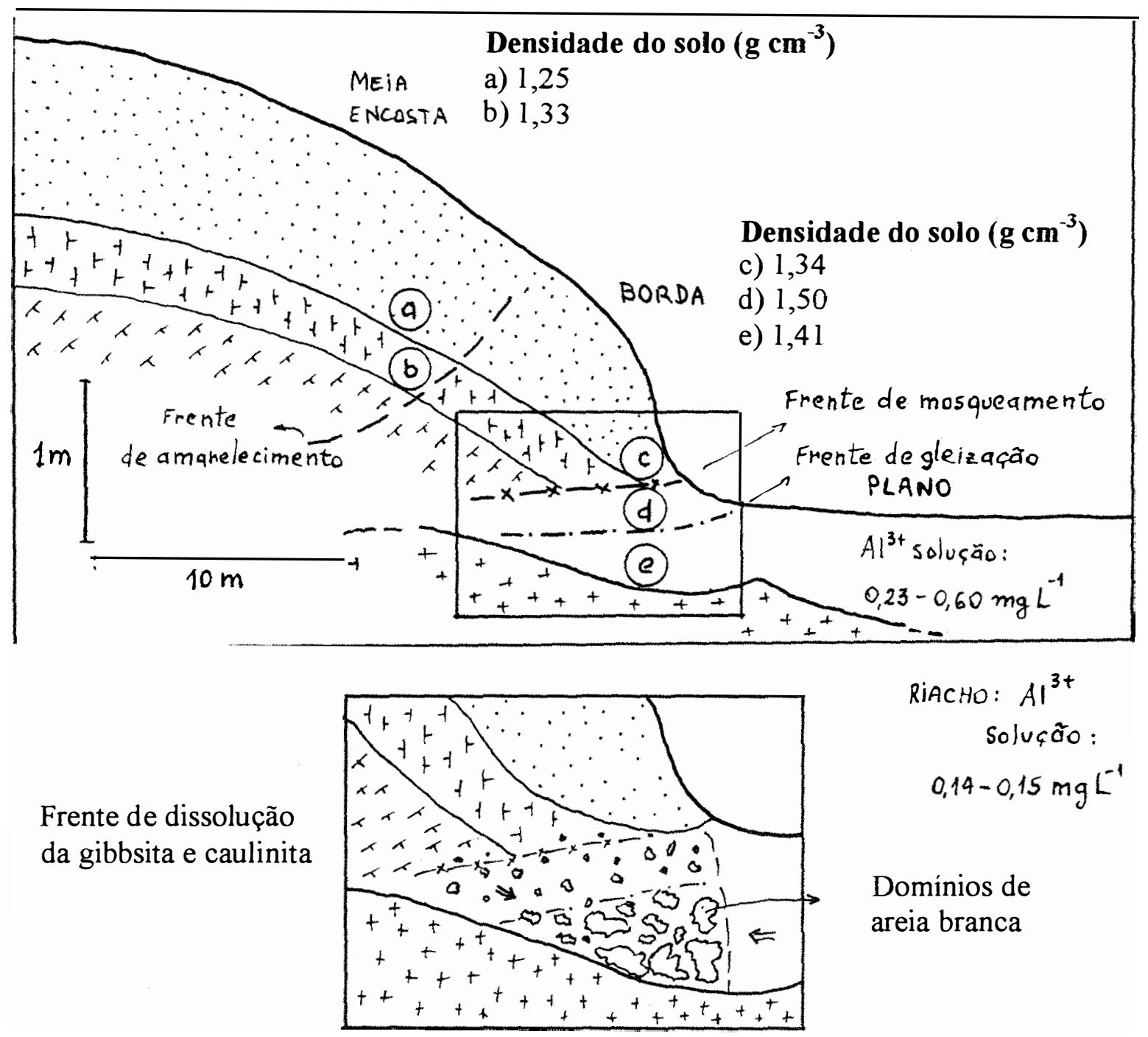

\section{Detalhe do contato}

\section{Legenda:}

$\Rightarrow$ Circulação de água

Volume 1, conjunto latossólico

Volume 2, conjunto intermediário

Volume 3, alterita vermelha ou amarela

国 Granito

Figura 29 - Representação da formação dos domínios arenosos em subsuperficie nas proximidades da borda da colina, com indicação dos conjuntos pedológicos, frentes de diferenciação, valores de densidade do solo e concentrações de $\mathrm{Al}^{3+}$ nas águas da planície hidromórfica. 
A composição mineralógica oferece evidências da dependência entre os constituintes do solo e o granito na planície hidromórfica. Na fração argila identificou-se vermiculita-ilita no material abaixo do horizonte $\mathrm{Bh}$ endurecido e traços de ilita no conjunto claro sob o horizonte Bh solto. As micas foram identificadas na fração silte, em subsuperficie, e, os feldspatos ocorrem nas frações silte e areia fina, inclusive no conjunto arenoso superior (volumes 6 e 7).

\subsection{Transformação dos solos na colina e formação das areias brancas}

A diferenciação dos solos influenciada pelo hidromorfismo se manifesta na colina, com distribuição simétrica dos materiais avermelhados, amarelados e acinzentados (Figura 9), o que permite admitir o amarelecimento sendo o precursor da gleização dos solos nessas seqüências. $O$ amarelecimento, que se verifica na alterita nas porções superiores das vertentes, ocorre também nas bordas da colina. Este processo pode ser relacionado com a dissolução preferencial da hematita em relação a goethita neste ambiente (Jeanroy et al., 1994). A partir daí, em meio alagado, os óxidos de ferro seriam eliminados na forma reduzida, resultando num material acinzentado. Este conjunto está relacionado ainda ao fluxo lateral de soluções que circulam em subsuperficie nos solos da colina e convergem para a porção inferior das vertentes. Este fato foi observado no contato da alterita acinzentada com a rocha, quando da abertura das trincheiras na borda da colina. A deferruginização constatada nos solos da periferia da colina se reflete na perda da estrutura em agregados, conferindo um aspecto maciço e menos poroso. Isso foi comprovado pelas observações micromorfológicas e pelo aumento da densidade no conjunto mosqueado e acinzentado da borda da colina (Figura 29).

As variações no formato do contato colina-planície e as diferentes formas de disposição da rocha podem ser interpretadas como etapas evolutivas da cobertura pedológica, repercutindo sobre o aspecto morfológico do terreno. Nas vertentes mais longas e com menor declividade, a rocha separa os domínios latossólico e hidromórfico, representando um estágio pouco avançado de alteração. A 
rocha está acima do nível do lençol freático e apresenta-se pouco fraturada. O solo permanece estável e evolui gradativamente no sentido vertical, ocasionando o aprofundamento da rocha. Nas vertentes mais curtas, com contornos da borda da colina mais recortados, a transição entre esses domínios ocorre entre o barranco na borda da colina e o início do plano, numa faixa de 1 a $5 \mathrm{~m}$ (Figura 30). A diferenciação lateral progressiva destes solos se manifesta da periferia para o centro da colina, em decorrência do hidromorfismo e do fluxo lateral de água. A perda de plasma argiloso é intensa nesta zona e resulta na formação de um material arenoso claro. A perda de argila na borda da colina possivelmente se dá de maneira semelhante para gibbsita e caulinita, que mantêm mesma proporção no material latossólico e na alterita acinzentada (Figura 20).

Um dos processos possivelmente envolvido na alteração dos materiais na borda da colina é a erosão mecânica, favorecida pela desestabilização da agregação, em virtude da perda dos óxidos de ferro. As argilas podem migrar em subsuperficie acompanhando o fluxo hídrico lateral. A ação da erosão superfícial parece exercer um papel secundário nos solos estudados, pois, a superficie do solo encontra-se constantemente coberta pelas plantas e serapilheira, protegendo-o contra a desagregação. Na superficie do solo não foram identificados sinais de erosão hídrica. Além disso, este processo dificilmente poderia explicar a formação de barrancos com as paredes acentuadamente inclinadas, bem como o desenvolvimento de uma depressão fechada.

O processo de ferrólise supostamente não se desenvolve neste ambiente, onde os solos são constantemente úmidos e as flutuações do nível freático são pouco intensas. Este processo foi inicialmente verificado em planossolos do Paquistão, que desenvolviam gradiente textural abrupto entre o horizonte A e B, numa estreita camada (alguns centímetros), em condições contrastadas de umectação e dessecação (Brinkman, 1970). A ferrólise tem sido relatada na transformação de latossolos para solos arenosos em outras situações na Amazônia. Andrade (1990), refere-se à participação deste processo, agindo juntamente com a acidólise, para explicar a diferenciação de solos formados sobre rochas cristalinas, na região sul de 


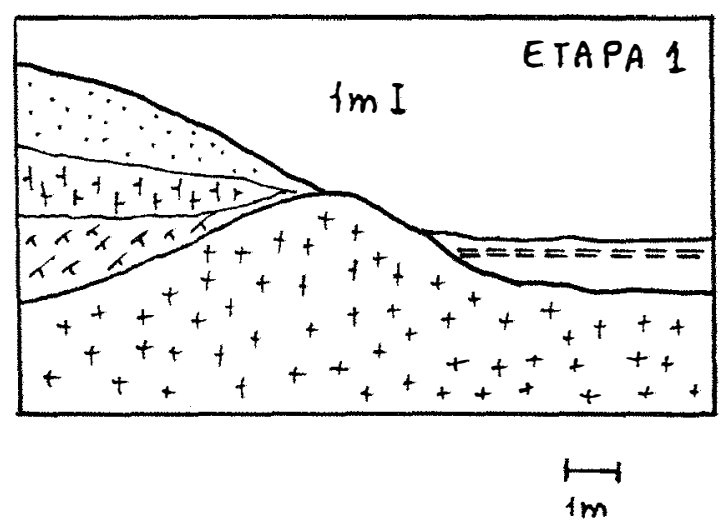

1) A rocha separa os domínios latossólico e hidromórfico, acima do nível do lençol freático da planície

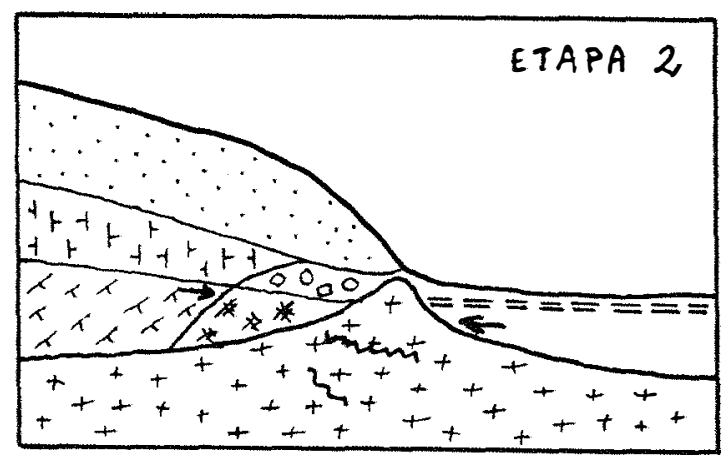

2) A rocha encontra-se mais intemperizada próximo ao nível do lençol freático da planície. O fluxo lateral é pequeno. Há desenvolvimento do conjunto acinzentado

ETAPA 3

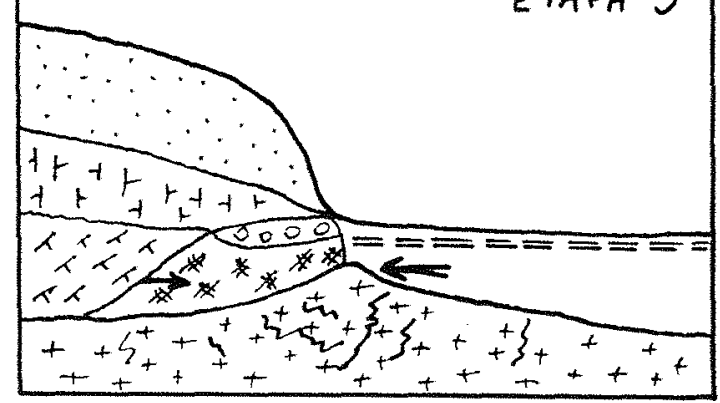

3) A rocha encontra-se fraturada e o lençol freático da planície atinge o material da colina. O fluxo lateral é mais intenso e o conjunto acinzentado é mais desenvolvido

\section{Legenda:}

$\Rightarrow$ Circulação de água $\quad=$ Nível do lençol freático

용 Volume 1, conjunto latossólico

国 Volume 4, conjunto mosqueado

Volume 2, conjunto intermediário

图 Volume 5, alterita acinzentada

图 Volume 3, alterita vermelha ou amarela 国 Granito

Figura 30 - Etapas evolutivas da cobertura pedológica na periferia da colina, salientando-se a variação na profundidade e grau de fraturamento da rocha e, na circulação hídrica em subsuperficie. 
Roraima. Em outro estudo, esses dois processos são citados como responsáveis pela diferenciação de latossolos em Areias Quartzosas Hidromórficas, desenvolvidas sobre sedimentos da Formação Barreiras no sul do Pará (Demattê et al., 1994).

$\mathrm{O}$ processo pedogenético que pode estar atuando com maior destaque neste ambiente, provocando a perda de argila em meio hidromórfico, é a acidólise. Este processo é caracterizado pela solubilização das argilas em $\mathrm{pH}$ baixo $(<5)$, pela ação de soluções contendo ácidos orgânicos provenientes da decomposição parcial da fitomassa em meio anaeróbio. Muitos ácidos orgânicos são capazes de complexar o Al, intensificando a destruição dos minerais (Melfi \& Pedro, 1978; Bonneau \& Souchier, 1994). A acidez pode também ser advinda da absorção de cátions pelas plantas ou resultante do $\mathrm{CO}_{2}$ produzido de pela respiração radicular (Grimaldi \& Pedro, 1996). A acidólise pode ser separada em dois estágios que correspondem a podzolização ou acidólise total e a aluminossilalitização ou acidólise parcial (Bonneau \& Souchier, 1994). No primeiro caso as soluções são fortemente ácidas $(\mathrm{pH}<4)$ e o alumínio é completamente dissolvido e complexado por ácidos orgânicos. No segundo caso, as soluções são ácidas, com pH entre 4 e 5 e o alumínio é hidroxilado, podendo depositar-se em minerais $2: 1$. Este processo provavelmente tem se manifestado na seqüência estudada, onde se constatam vermiculitas aluminosas na alterita acinzentada da borda da colina. Este tipo de mineral tem sido utilizado inclusive como indicador do meio de alteração (Righi et al., 1990; Jamet et al., 1996). Outro aspecto a considerar é que, na acidólise parcial, haveria condições para permanência de gibbsita, o que não ocorreria no caso da presença soluções ácidas e complexantes, típicas do processo de podzolização, que dissolvem a gibbsita, formando compostos amorfos semelhantes a alofanas (Robert et al., 1987).

A expressão da acidólise parcial na região está de acordo com as condições de $\mathrm{pH}$ das águas escuras que escoam nesses solos planos. Algumas determinações efetuadas no Rio Negro, em Cucuí, AM (Universidade de Brasília, 1999), nas proximidades do local de estudo, indicam valores de $\mathrm{pH}$ entre 3,5 e 4,5, semelhantes aos valores relatados por Sioli (1975) para região do alto Rio Negro. 
A concentração $\mathrm{Al}^{3+}$ nas águas pode confirmar a solubilização da gibbsita e caulinita na borda da colina, o que poderia explicar a formação das areias brancas. As concentrações de $\mathrm{Al}^{3+}$ em solução encontradas nas proximidades da borda da colina foram de 0,23 a $0,60 \mathrm{mg} \mathrm{L}^{-1}$, superiores à concentração da água do riacho, que foi de 0,14 a $0,15 \mathrm{mg} \mathrm{L}^{-1}$. Essa diferença entre a concentração de $\mathrm{Al}^{3+}$ encontrada nas águas próxima da colina em relação àquela do riacho, pode ser atribuída 'a redistribuição desse elemento em profundidade nos solos da planície hidromórfica. As concentrações de $\mathrm{Al}^{3+}$ nas águas na região do alto Rio Negro variam entre 0,00 e $0,17 \mathrm{mg} \mathrm{L}^{-1}$ (Sioli, 1968). Essas concentrações permitiriam uma exportação de $\mathrm{Al}^{3+}$ em solução pelo Rio Negro da ordem de $0,2 \mathrm{~g} \mathrm{~m}^{-2}$ ano (Chauvel et al., 1987), o que é muito semelhante aos valores por nós determinados no eixo de drenagem.

Esses estudos sobre a dinâmica de espécies químicas em solução são escassos na região Amazônica, na maioria das vezes orientados para a ciclagem de nutrientes pela vegetação (Franco \& Dezzeo, 1994; Lesack \& Melack, 1996; Forti et al., 1997).

Esses resultados apontam para transformação dos latossolos na borda da colina, formando as areias brancas a partir da alterita acinzentada, numa distância inferior a uma dezena de metros. Esta transformação estaria relacionada com a forma superficial do terreno, com o desenvolvimento de barrancos acentuadamente inclinados, presentes nos montículos arredondados e nas paredes da depressão fechada. Outra implicação da alteração dos solos seria a redução lateral na espessura do conjunto latossólico, que se verifica em direção às bordas da colina.

A perda de argila constatada na borda da colina se processa principalmente no conjunto acinzentado, que está em contato com águas ácidas da planície hidromórfica adjacente. A perda de argila no conjunto latossólico disposto acima do nível do lençol freático é restrita em algumas porções, bem próximas da periferia da colina, como observado em TR2/I, que tem $200 \mathrm{~g} \mathrm{~kg}^{-1}$ de argila no horizonte Bw (Figura 28). Na outra seqüência (TR3/I) a textura no horizonte amarelado superior $(\mathrm{Bi})$ na borda da colina, permanece eqüivalente àquela das 
porções superiores da colina ( $320 \mathrm{~g} \mathrm{~kg}^{-1}$ de argila). Esta variação possivelmente seja ocasionada por arraste mecânico em função da convergência do fluxo hídrico lateral em algumas zonas.

A diminuição da espessura do conjunto latossólico na borda da colina relaciona-se com o processo de perda de argila que ocorre na alterita hidromórfica, por ação das águas ácidas provenientes do plano. A remoção contínua de materiais nas camadas inferiores por erosão geoquímica (dissolução), levaria ao afundamento progressivo dos solos nestas porções, da base para o topo, expondo o material latossólico superior à hidromorfia, provocando sua desestabilização e degradação (Figura 31).

Essa transformação de latossolos em solos arenosos tem sido verificada em áreas formadas sobre rochas sedimentares da Amazônia (Lucas, 1989) e da região Nordeste do Brasil (Ribeiro, 1998), ou mesmo sobre o embasamento cristalino (Andrade, 1990; Dubroeucq \& Volkoff, 1998). Nesses casos, foi observada instalação do processo de podzolização no interior do conjunto latossólico, que mostrava gradual empobrecimento lateral em argila em direção à porção inferior das vertentes, numa escala decamétrica. No caso ora estudado, essa diferenciação se processa principalmente abaixo do nível do lençol freático, agindo sobre a alterita, de forma mais abrupta (escala métrica).

A evolução lateral do latossolo pode ser relacionada com a morfogênese, podendo-se supor que a dissolução de partículas (argilas) nas bordas da colina, deixando como produto o material arenoso, contribuiria para o aplainamento do modelado. $\mathrm{O}$ "desgaste" das colinas é manifestado pela intensidade de recorte dos contornos na borda da colina (formatos digitados e irregulares). O desenvolvimento de depressões fechadas ou montículos arredondados, também indicativos da remoção de material nas bordas da colina, parece estar ligado ao controle exercido pela rocha. As variações quanto à profundidade e grau de fraturamento da rocha possibilitariam o surgimento de caminhos preferenciais d'água em subsuperficie, implicando em perdas localizadas de materiais. A forma inclinada dos barrancos pode estar ligada ao solapamento e desmoronamento, em virtude da perda de material na base (Figura 32). 


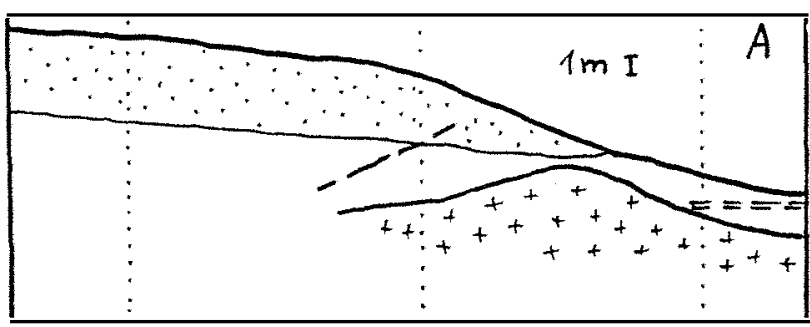

im
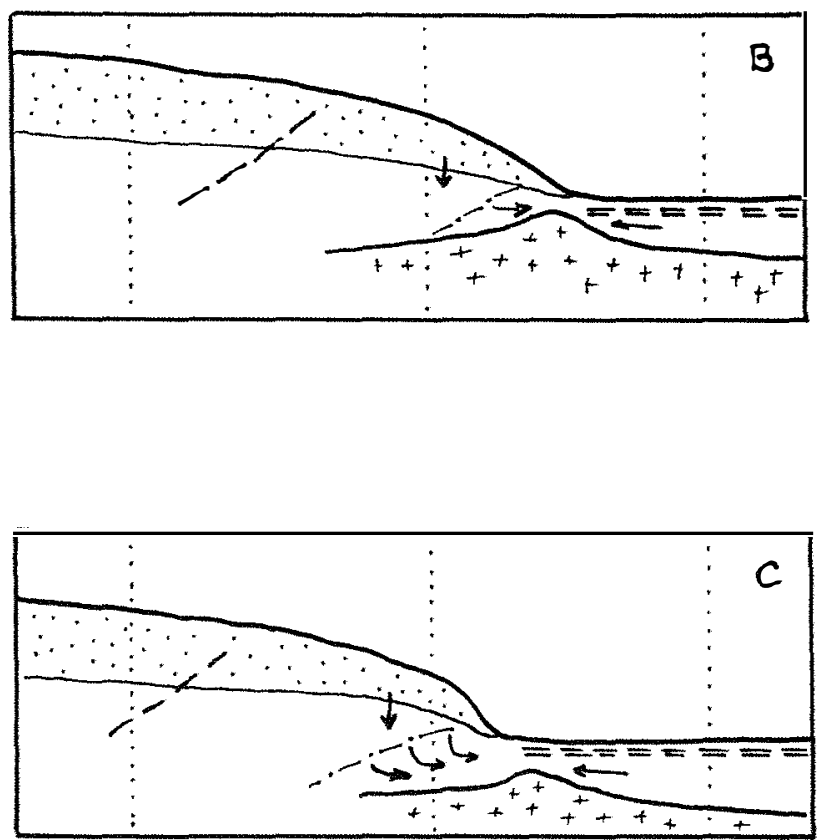

C) As perdas de alumínio se acentuam na borda da colina, observa-se acúmulo relativo de quartzo; aumento do conjunto acinzentado e rebaixamento gradativo da superficie; o manto arenoso formado na periferia da colina se aprofunda

\section{Legenda:}

$\Rightarrow$ Circulação de água

= Nível do lençol freático

Volume 1, conjunto latossólico

国 Granito

Figura 31 - Interpretação da transformação dos solos na colina pelo contato com meio hidromórfico na periferia. (- - -) Frente de amarelecimento; (-...) Frente de gleização. 


\subsection{Pedogênese nos solos da planície hidromórfica e evolução do manto arenoso}

A formação das areias presentes na planície hidromórfica pode envolver a transformação de uma cobertura latossólica pré-existente, cuja dinâmica lateral, por destruição dos argilominerais, deixaria como resíduo o esqueleto de quartzo. Esta interpretação pode ser reforçada por outros estudos pedológicos recentes (Dubroeucq et al., 1991; Dubroeucq \& Volkoff, 1998; Thomas et al., 1999). Diferentes estágios evolutivos desse processo poderiam ser constatados no campo: uma primeira etapa de evolução se revela na faixa em torno da colina, em que a rocha encontra-se a pouca profundidade, coberta pelo manto arenoso menos desenvolvido. As fases mais adiantadas de diferenciação dos solos são notadas a medida que se afasta da colina, onde se tem o aprofundamento da rocha e avanço do intemperismo em profundidade. Neste caso, observa-se a presença da alterita (ou saprolito) e, a medida que esta se aprofunda, verifica-se a formação do conjunto claro arenoargiloso. Essas etapas de evolução mostram-se organizadas de forma simétrica em torno da colina, conforme discutido anteriormente.

Para justificar o aplainamento do terreno relacionado com o processo pedogenético de formação de areias, Lucas et al., (1988) realçam que a evolução lateral da cobertura latossólica teria que se dar com velocidade relativa superior à alteração vertical do manto arenoso. Outra ação com provável participação no nivelamento superficial dessas superficies arenosas, seria derivada de processos coluviais e aluviais, agindo de maneira mais localizada. Alguns fatores podem contribuir para a ocorrência generalizada dessas áreas arenosas na região do alto Rio Negro, tais como: a) diferenças na história geológica, possivelmente relacionadas a movimentos tectônicos, os quais são citados por Costa et al. (1996), que teriam como conseqüência mudança no nível de base regional, possibilitando a ação do hidromorfismo sobre os latossolos; b) espessura possivelmente menor das coberturas latossólicas na alta bacia amazônica em relação ao verificado na média bacia; e c) maior pluviosidade em relação a outras partes da Amazônia. 

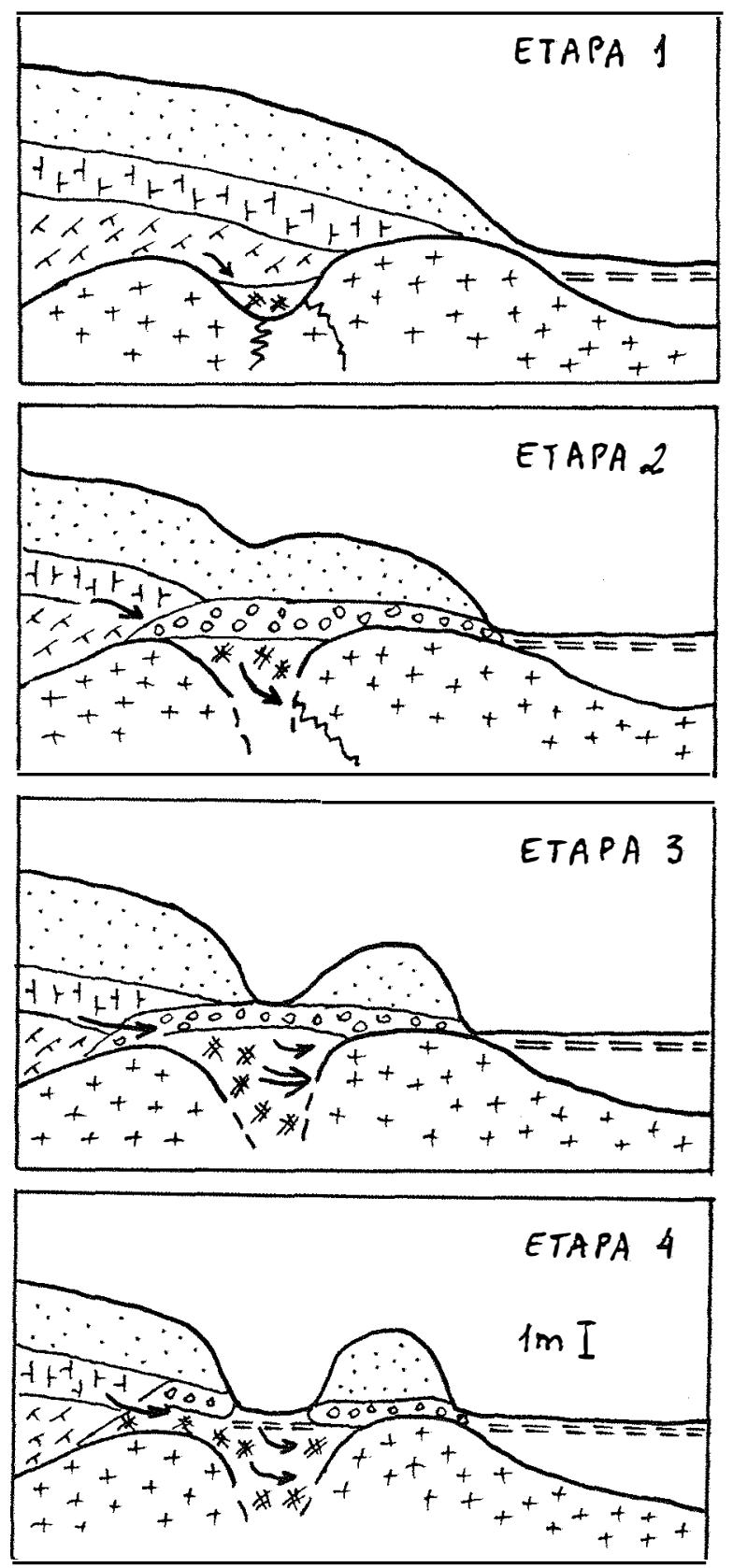

$$
\longmapsto
$$

\section{Legenda:}

$\Rightarrow$ Circulação de água $\quad=$ Nível do lençol freático
Volume 1, conjunto latossólico
Volume 4, conjunto mosqueado
Volume 2, conjunto intermediário
Volume 5, alterita acinzentada
图 Volume 3, alterita vermelha ou amarela

1) Rocha fraturada com formação de alterita hidromórfica em subsuperficie, com pequena circulação hídrica lateral com a planície hidromórfica

2) O fraturamento da rocha permite um avanço da alterita hidromórfica, com aumento do fluxo lateral, concentrando-se na zona de aprofundamento da alterita, aumentando as perdas de materiais $\mathrm{e}$ rebaixando a superficie

3) A alterita hidromórfica se aprofunda e intensifica-se o fluxo lateral. A perda de material é mais acentuada e o

4) Forma-se uma depressão, atingindo o nivel do lençol da planície, a circulação hídrica é intensa e as perdas são aumentadas, com progressão lateral do buraco, conferindo um aspecto inclinado às paredes rebaixamento se pronuncia

Figura 32 - Etapas evolutivas da cobertura pedológica na periferia da colina, salientando-se formação da depressão fechada e montículos arredondados com paredes inclinadas. 
A diferenciação na composição mineralógica verificada nos materiais em subsuperficie na planície hidromórfica mostra relação com a profundidade de alteração da rocha e com a proximidade do eixo de drenagem. As variações encontradas estão ainda ligadas com o tipo de horizonte Bh. Nas posições em que a alterita (saprolito, volume 11 ) está presente mais próxima da superficie $( \pm 1,4 \mathrm{~m})$, na zona oposta ao eixo de drenagem, o Bh encontra-se endurecido. Neste caso o material subsuperficial tem constituição mineralógica predominantemente gibbsítica na fração argila. O Bh solto, com enriquecimento menos acentuado em matéria orgânica, ocupa as porções sobrepostas ao conjunto claro areno-argiloso, caulinítico (Volume 10), disposto sobre a alterita mais profunda $(+2 \mathrm{~m})$. Este $\mathrm{Bh}$ abrange maior parte da planície hidromórfica (Figura 33).

O saprolito composto por gibbsita na planície hidromórfica pode ser interpretada como um material formado "in situ", o que é evidenciado pela ocorrência desse mineral associado a pseudomorfos de feldspatos. Sua formação, neste caso, prescinde de meio bem drenado e soluções pobres em silício. As condições de estabilidade e formação da gibbsita têm sido determinadas em estudos termodinâmicos, necessitando de soluções com atividade de silício inferior a $1 \mathrm{mg} \mathrm{L}^{-1}$ à $25^{\circ} \mathrm{C}$ e em condições de pH entre 5 e 6 (Buol et al., 1997). A permanência desse mineral em áreas atualmente alagadas pode ser justificada pela disposição irregular da rocha em relação à superficie, com menor fraturamento nesta porção do terreno, que possibilitaria a formação de ambientes confinados e pouco sujeitos ao contato com soluções mais ricas em silicio. Outra explicação para a estabilidade da gibbsita seria decorrente da proteção exercida pelo horizonte Bh cimentado com matéria orgânica, limitando os fluxos hídricos abaixo desta camada.

A ocorrência de gibbsita em grande quantidade em meio hidromórfico e sob uma camada de quartzo é uma constatação interessante e ainda não evidenciada nos estudos pedológicos que nos precederam. Algumas hipóteses, além daquela relacionada com sua disposição num meio confinado, podem ser levantadas para explicar tal situação. Uma delas seria atribuida a rápida circulação das águas na camada arenosa, que ocasionaria um equilibrio com baixas concentrações de silício. 

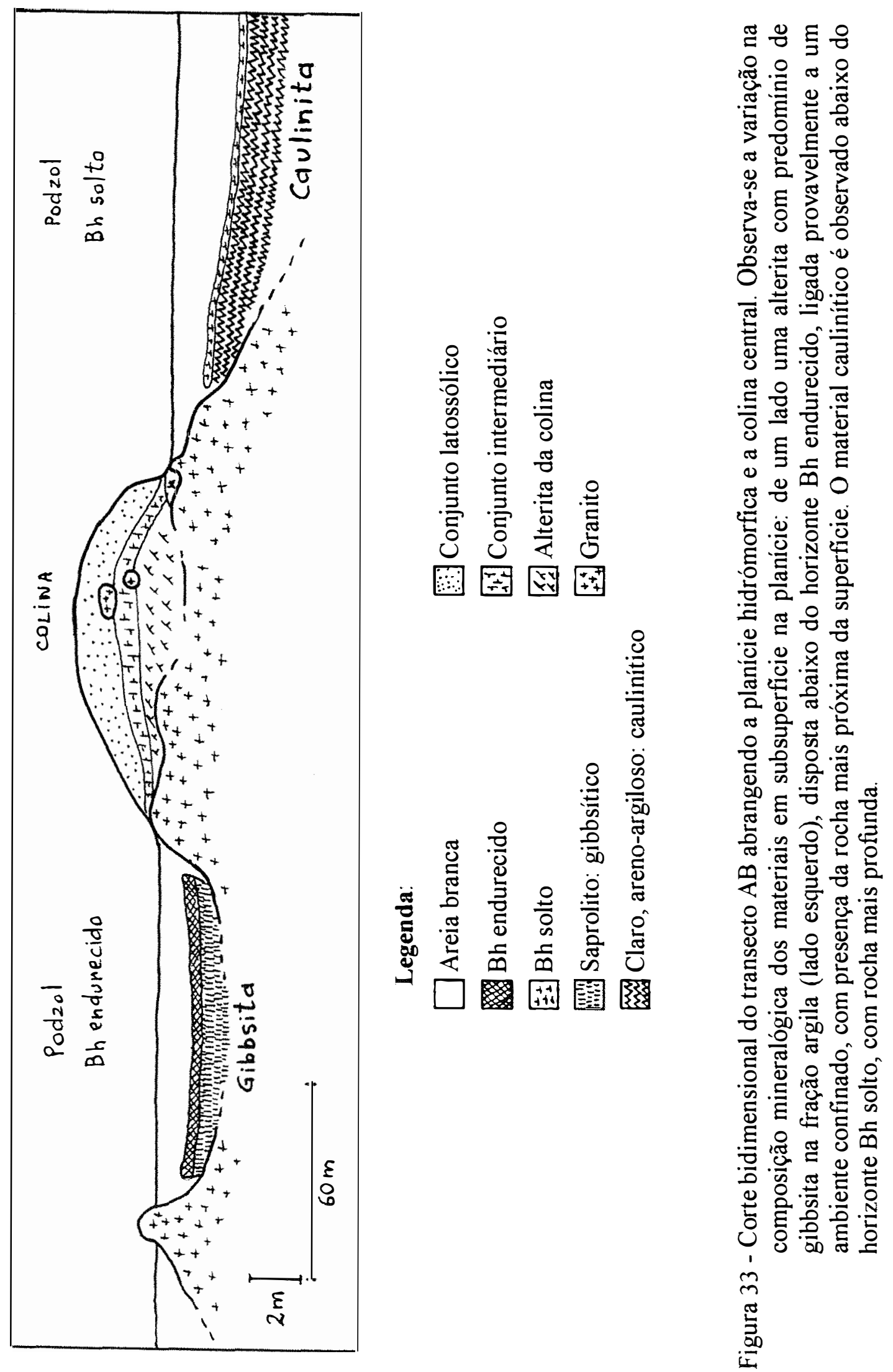
Esta hipótese está em conformidade com Lucas (1997), que admite teores crescentes de silício acompanhando o tempo de residência das soluções em contato com os minerais do solo. Outra suposição pode ser discutida com base no equilíbrio do sistema gibbsita-caulinita-quartzo. A dissolução de um mineral é depende de fatores como cristalinidade, temperatura, composição química das soluções e pressão parcial de $\mathrm{CO}_{2}$ do meio (Tardy, 1993). Destes fatores, possivelmente a cristalinidade da gibbsita pode ter efeito, uma vez que foram encontrados macrocristais nos nódulos presentes na borda da colina (Figura 22c), favorecendo sua permanência em equilíbrio com quartzo. Outro aspecto é referente a atividade da água, que estando próxima de 1 (meio saturado na planície hidromórfica) favoreceria o equilíbrio quartzo-gibbsita em relação a caulinita (Tardy \& Roquin, 1992). Esta influência pode estar relacionada com o decréscimo nos teores de caulinita em relação a gibbsita observados no perfil P1 (Figura 20).

A presença de caulinita em subsuperfície nos solos da planície hidromórfica pode ser atribuída à deposição de partículas em suspensão, arrastadas com o fluxo d'água subsuperficial ou, ainda, à formação "in situ". A primeira alternativa não foi evidenciada no exame micromorfológico, que revela distribuição relativamente uniforme do plasma, algumas vezes localizado em pápulas formadas por intemperismo de feldspatos, sem formação de argilãs ou outra estrutura de deposição de argila. A gênese da caulinita neste material pode ser resultante do intemperismo local dos minerais primários ou pela neoformação, contando com o aporte de $\mathrm{Si}$ e Al em solução, provenientes da degradação de argilominerais na colina. Isto inclusive pode justificar a diferença entre os teores mais elevados de $\mathrm{Al}^{3+}$ nas águas provenientes da periferia da colina em relação a água do riacho. A ocorrência de caulinita em subsuperficie em parte dos solos da planície hidromórfica é concordante com outras avaliações efetuadas em materiais da região (Dubroeucq \& Volkoff, 1988), sendo também relatada numa seqüência de solos semelhantes desenvolvidos sobre granodiorito em Kalimantan, Indonésia (Thomas et al., 1999). 


\subsection{Podzolização e formação do horizonte Bh}

A caracterização morfológica do horizonte $\mathrm{Bh}$ aponta para um acúmulo de matéria orgânica, que constitui um plasma isotrópico, localizado nos espaços intergranulares e em canais orientados verticalmente, sem formação de revestimentos no esqueleto. Essa disposição é concordante com as descrições de outros podzóis hidromórficos apresentadas por Farmer et al. (1983). Um dos mecanismos responsáveis pela deposição da matéria no horizonte Bh é proposta por Dubroeucq \& Volkoff (1988), que discutem o desenvolvimento de podzóis hidromórficos na região do alto Rio Negro. Nestes solos, a matéria orgânica circula junto com as soluções e seria filtrada em camadas subsuperficiais adensadas pela presença de grãos de quartzo de pequeno tamanho, fragmentados por dissolução química intensa.

O movimento e redistribuição da matéria orgânica nos solos por nós estudados é favorecido pelo fluxo lateral de soluções na planície hidromórfica, o que foi constatado quando da abertura das trincheiras nesta área. A precipitação de materiais orgânicos em suspensão na água também foi observada nas trincheiras aí abertas. A água escura com partículas em suspensão, presentes quando da movimentação da terra, tornava-se bruno-amarelada após a decantação desses materiais. A deposição de matéria orgânica por filtragem em subsuperfície numa camada mais adensada é concordante com a disposição morfológica dos materiais, que revela desnível do horizonte $\mathrm{Bh}$, acompanhando a camada de alterita ou o conjunto claro mais argiloso subjacentes, que se aprofundam a medida que se afasta da colina.

Além da filtragem dos compostos orgânicos em suspensão pela camada subsuperfical adensada, a formação do horizonte $\mathrm{Bh}$ pode se provocada pela precipitação de suspensões ricas em compostos orgânicos que poderiam se combinar com alumínio presente nas águas subsuperficiais (Farmer et al., 1983).

As variações entre o horizonte $\mathrm{Bh}$ solto e endurecido podem estar ligadas à intensidade do fluxo hídrico subsuperficial, que poderia se acentuar em 
direção ao eixo de drenagem, refletindo em soluções com menor carga orgânica, formando o Bh solto (menos enriquecido em matéria orgânica). Outro aspecto referese a composição do material subsuperficial. Na porção relacionada ao $\mathrm{Bh}$ endurecido a constituição do solo é predominantemente gibbsítica, permitindo a ligação da matéria orgânica ao alumínio, que ocasionaria a cimentação dos materiais.

A contribuição da biota, em especial das minhocas, mostra-se importante nesses solos da planície hidromórfica, interferindo na distribuição da matéria orgânica em subsuperficie. Os estudos sobre o comportamento ecológico desses animais nos solos da Amazònia são muito escassos (Ayres \& Guerra, 1981). As observações micromorfológicas indicam a participação das minhocas na fragmentação da matéria orgânica e incorporação ao material mineral, o que é evidenciado pela grande quantidade de fragmentos vegetais presentes nos coprólitos. Esses animais podem contribuir para a mistura vertical de materiais no solo, criando canais que favorecem a circulação de soluções e matéria orgânica. Aliás, muitos pedotúbulos presentes no horizonte $\mathrm{Bh}$ apresentavam concentrações de plasma orgânico, com aspecto semelhante àquele presente no conjunto do solo.

A formação dos podzóis hidromórficos se instala nos solos arenosos mais profundos, ligados a presença do conjunto claro areno-argiloso ou a alterita subsuperficiais, o que sugere uma evolução posterior a formação do material arenoso, que se processa a partir da periferia da colina. A disposição da camada arenosa, diretamente sobre a rocha pouco profunda numa faixa circundando a colina, indica uma primeira fase evolutiva, que se encontra separada lateralmente dos solos arenosos mais profundos, onde se desenvolve o horizonte $\mathrm{Bh}$.

Os indicativos referentes a composição mineralógica, que são a ocorrência de vermiculitas aluminosas na alterita hidromórfica na borda da colina e, a presença de grandes quantidade de gibbsita no meio hidromórfico sugerem que o processo de formação desses solos arenosos está ligado a acidólise parcial ou aluminossialitização. A podzolização verdadeira do ponto de vista geoquímico parece pouco provável nestas condições. 


\section{CONCLUSÕES}

A seqüência estudada é representativa de áreas planas que compõem a bacia do alto Rio Negro, cobertas por solos arenosos como podzóis hidromórficos, onde aparecem áreas localizadas de latossolos em colinas baixas. A cobertura pedológica ai presente mostra evidências (morfológicas e analíticas), que indicam desenvolvimento autóctone e filiação com o material de origem granítico. Os latossolos mostram relações pedogenéticas com os materiais do domínio hidromórfico, que apontam para uma transformação progressiva, ligadas a condições de saturação hídrica crescente, iniciando pelo amarelecimento acentuado, seguido pela gleização na periferia da colina. A formação do material arenoso ocorre abaixo do conjunto latossólico na borda da colina, constituindo uma evolução lateral, que se dá numa escala métrica.

O processo pedogeoquímico envolvido na perda de argila na borda da colina é a acidólise parcial, que provoca dissolução de grande quantidade de gibbsita e caulinita, liberando alumínio, o que é constatado por mudanças na composição das águas. $\mathrm{O}$ transporte mecânico de plasma na forma microparticular parece exercer papel secundário. Na planície hidromórfica observa-se acúmulo de quartzo compondo as areias brancas. Abaixo deste conjunto eluvial verifica-se, num lado da seqüência, uma alterita com gibbsita, sob o horizonte $\mathrm{Bh}$ endurecido. Na maior parte da área, ocorre um conjunto claro areno-argiloso, com predomínio de caulinita na fração argila, disposto abaixo do horizonte Bh solto.

A formação do horizonte $\mathrm{Bh}$ do podzol hidromórfico é um processo posterior a formação do material arenoso e se dá pela redistribuição de matéria orgânica, acompanhando o fluxo hídrico subsuperficial. No horizonte espódico observa-se um 
plasma orgânico preenchendo os espaços intergranulares e canais de raizes, depositado por ação mecânica de filtração, em virtude da presença de uma camada mais adensada em contato com o saprolito ou material claro subsuperficial mais argiloso. A precipitação de compostos orgânicos, ligados ao alumínio presente em soluções em subsuperficie, pode também estar envolvida na gênese do horizonte $\mathrm{Bh}$.

$O$ tipo de podzolização encontrada nessa seqüência difere da verificada em outras áreas estudadas na Amazônia, e se caracteriza fundamentalmente pela ação das águas ácidas da planície hidromórfica sobre o solo mais argiloso da colina. As areias brancas formam-se nestas condições a partir da base do conjunto latossólico, que se desestabiliza e se degrada a medida que ocorre a remoção da fração fina, provocando o rebaixamento do terreno e contato com as águas do plano. A evolução lateral dos solos no sentido latossolo-podzol hidromórfico reforça a hipótese de formação das areias brancas por processos pedogeoquímicos e contribui para explicar o aplainamento geral do terreno observado nesta região.

Estudos complementares são necessários para compreender a dinâmica do alumínio e matéria orgânica e a velocidade dos processos envolvidos na diferenciação desses solos. 


\begin{abstract}
ANEXO A
Descrição macromorfológica dos perfis estudados
\end{abstract}




\section{DESCRIÇÃO MACROMORFOLÓGICA DOS PERFIS}

A caracterização macromorfológica detalhada dos solos foi efetuada em sete trincheiras. $\mathrm{Na}$ colina foram descritos dois perfis, um no topo $(\mathrm{C} 1)$ e outro em meia encosta (C2) (Tabela 9). No contato colina-planície foram abertas três trincheiras (TR1, TR2 e TR3). Estas abrangiam o material arenoso sobre a rocha na planície hidromórfica, até o perfil de solo amarelado na borda da colina (Tabela 10). Na planície hidromórfica foram caracterizados três perfis (Tabela 11), sendo dois compostos por solos com presença de horizonte Bh (P1 e P3) e outro por um solo com presença de areia branca sobre a rocha $\mathbf{( P 2 )}$.

\section{Solos da colina}

1.1. Topo da colina - C1: LATOSSOLO AMARELO, solo profundo, caracterizado pela presença de material amarelado, de textura média (horizonte $\mathrm{Bw}$ ), com matacões de rocha em subsuperficie, em diferentes estágios de decomposição. A seqüência de horizontes é $\mathrm{O}, \mathrm{A}, \mathrm{BA}, \mathrm{Bw}, \mathrm{BC} 1, \mathrm{C}$ e $\mathrm{C} / \mathrm{R}$ (Figura 34).

- Horizonte 0: 1-0 cm; material orgânico parcialmente decomposto. Raízes finas muito abundantes formando um tapete denso. A transição é abrupta e plana.

- Horizonte A: 0-2 cm; bruno-acinzentado-escuro (10YR 4/2, seco) e bruno-acinzentadomuito-escuro (10YR 3/2, úmido); franco-arenosa, predomínio de areia fina; estrutura grumosa e granular, média ( 3 a $4 \mathrm{~mm}$ ), moderada; consistência seca muito macia e muito friável quando úmida; não plástica e não pegajosa; raizes finas muito abundantes; porosidade muito abundante, entre grumos e tubular; transição abrupta e plana.

- Horizonte BA: 2-20 cm; amarelo (10YR 8/8, seco) e amarelo-brunado (10YR 6/8, úmido); franco-argilo-arenosa com predomínio de areia fina e média; estrutura maciça e granular, média, fraca; consistência seca macia a ligeiramente dura; muito friável quando úmida; ligeiramente plástica e ligeiramente pegajosa; presença abundante de raizes finas; porosidade abundante e tubular. A porção superior é composta por material mais arenoso e frouxo, muito poroso. Há domínios milimétricos irregulares e difusos na porção superior com coloração bruno-amarelado (10YR $5 / 6$, úmido) e amarelo-brunado (10YR 6/6, seco). Pedotúbulos com cerca de $2 \mathrm{~mm}$ de diâmetro com material microgranular e de coloração semelhante à matriz; transição gradual e plana.

- Horizonte Bw: 20-120 cm; amarelo (10YR 7/8, seco) e amarelo-brunado (10YR 6/8, úmido); franco-argilo-arenosa a argila-arenosa com areia fina e média; maciça $\mathrm{e}$ estrutura forte, muito pequena, granular; consistência seca macia a ligeiramente dura; muito friável quando úmida; plástica e pegajosa; presença comum de raizes finas; porosidade abundante, tubular. Carvões em pequena quantidade a $50 / 60 \mathrm{~cm}$ de profundidade. Presença de pedotúbulos com cerca de $2 \mathrm{~mm}$ de diâmetro com material granular muito pequeno e de coloração semelhante à matriz. Presença de cavidades formadas por formigas com formato arredondado, achatadas, com a maior dimensão no sentido horizontal, variando de 10 a $25 \mathrm{~cm}$ de comprimento por 6 a $10 \mathrm{~cm}$ de altura. Internamente preenchidas parcialmente por terra solta, da mesma coloração que a matriz do solo, na forma de agregados granulares pequenos a muito pequenos $(<2 \mathrm{~mm})$. As raizes estavam livres ou nas paredes. A transição é gradual e descontínua. 
- Horizonte BC: 120-195 cm; amarelo (10YR 7/8 e 10YR 8/8, seco) e amarelo-brunado (10YR 6/8, úmido); franco-argilo-arenosa a argila-arenosa com areia grossa e cascalho; maciça e forte, muito pequena, granular; consistência seca macia; muito friável quando úmida; ligeiramente plástica e ligeiramente pegajosa; poucas raizes; porosidade mediamente abundante, tubular. Partículas de mica parcialmente decomposta, com coloração amarelada. Volumes centimétricos de rocha parcialmente decomposta são visíveis, podendo-se identificar os cristais de feldspato intemperizado. Foi encontrada uma concreção ferruginosa, arredondada, com cerca de $1 \mathrm{~cm}$ de diâmetro, de coloração externa bruno-avermelhada (2.5YR 4/4, seco) e internamente vermelho (2.5YR 4/8, seco). A transição é clara e descontínua.

- Horizonte C: 195-250 cm; amarelo-avermelhado (5YR 7/6, seco e 5YR 6/8, úmido); franco-argilo-arenosa com areia grossa e cascalho; maciça e estrutura litológica; consistência seca macia; muito friável quando úmida; ligeiramente plástica $\mathrm{e}$ ligeiramente pegajosa; poucas raizes; porosidade mediamente abundante, tubular. Mica parcialmente decomposta abundante, com coloração amarelada. Os volumes de rocha parcialmente decomposta são mais abundantes, centimétricos, com coloração mais avermelhada do que no horizonte superior. Podem ser identificados cristais de feldspato intemperizados. A transição é clara e descontínua.

- Horizonte C/R: 250-380 cm; alterita de granito, passando de amarelo-avermelhado (5YR $7 / 6$, seco) e vermelho (2.5YR 5/8, úmido) no topo do horizonte, para amarelo (10YR 7/6, seco) e amarelo-brunado (10YR 6/8, úmido) na base; rocha fragmentada com cascalho; estrutura herdada da rocha; friável quando úmido; não plástica e não pegajosa. Presença litofragmentos centimétricos, sendo a matriz abundante em micas e de feldspatos alterados. O lençol freático estava presente a $3,7 \mathrm{~m}$ de profundidade, cerca de $10 \mathrm{~cm}$ acima da rocha.

1.2. Meia encosta - C2: LATOSSOLO AMARELO, solo profundo, com material de textura média, amarelado na porção superior do perfil, passando para avermelhado na base. A seqüência de horizontes é O, A, BA, Bw, BC, C e C/R (Figura 35).

- Horizonte O: 1-0 cm; material orgânico parcialmente decomposto. Raizes finas abundantes. A transição é abrupta e plana.

- Horizonte A: 0-4 cm; bruno-amarelado (10YR 5/4, seco) e bruno-escuro (10YR 4/3, úmido); franco-arenosa com predomínio de areia fina; estrutura grumosa e granular, pequena a média (até $5 \mathrm{~mm}$ ), fraca; consistência seca macia e friável quando úmida; ligeiramente plástica e não pegajosa; raízes finas abundantes; porosidade muito abundante, entre grumos e tubular; transição abrupta e plana.

- Horizonte BA: 4-17 cm; amarelo (10YR 7/6, seco) e bruno-amarelado (10YR 5/6, úmido); franco-arenosa a franco-argilo-arenosa com predomínio de areia fina e média; estrutura maciça e blocos subangulares, pequena, fraca; consistência seca macia; friável quando úmida; ligeiramente plástica e ligeiramente pegajosa; presença comum de raízes finas, algumas raizes médias e grossas; porosidade abundante, tubular. Pedotúbulos com cerca de $2 \mathrm{~mm}$ de diâmetro com material microgranular e de coloração semelhante à matriz; transição gradual e plana.

- Horizonte Bw: 17-130 cm; amarelo (10YR 7/6, seco) e amarelo-brunado (10YR 6/8, úmido) na porção superior (17 a $50 \mathrm{~cm}$ ), passando para amarelo $(10 \mathrm{YR} 7 / 6$, seco) e 
bruno-forte (7.5YR 5/8, úmido); franco-argilo-arenosa com areia fina e média; estrutura maciça, com subestrutura granular, muito pequena, forte e dominios com blocos subangulares, pequena, fraca; consistência seca macia; friável quando úmida; plástica e pegajosa; presença comum de raizes finas; porosidade abundante, tubular. A transição é difusa e plana.

- Horizonte BC: 130-165 cm; amarelo-avermelhado (7.5YR 7/8, seco) e bruno-forte (7.5YR 5/8, úmido); franco-argilo-arenosa com areia grossa e cascalho; maciça e forte, muito pequena, granular; consistência seca ligeiramente dura; friável quando úmida; ligeiramente plástica e ligeiramente pegajosa; poucas raízes; porosidade mediamente abundante, tubular. Partículas de mica parcialmente decomposta, com coloração amarelada. A transição é gradual e plana.

- Horizonte C: 165-210 cm; amarelo-avermelhado (5YR 6/6, seco) e vermelhoamarelado (5YR 5/8, úmido); franco-argilo-arenosa com areia grossa, cascalho abundante; maciça e estrutura litológica; consistência seca macia; friável quando úmida; ligeiramente plástica e ligeiramente pegajosa; poucas raízes; porosidade mediamente abundante, tubular. Mica parcialmente decomposta abundante, com coloração amarelada. A transição é gradual e plana.

- Horizonte C/R: 210-250 cm+; alterita de granito, amarelo-avermelhado (5YR 6/6, seco) e vermelho-amarelado (5YR 5/8, úmido); rocha fragmentada com cascalho; estrutura herdada da rocha; friável quando úmido; não plástico e não pegajoso. Presença abundante de mica e de feldspatos alterados.

\section{Solos do contato colina-planície}

2.1. Contato com rocha rocha próxima da superfície - TR1: trincheira com 8 metros de comprimento, partindo da porção arenosa até o material amarelado na borda da colina. Toda a base é composta pela rocha, localizada próxima à superficie (10 a $20 \mathrm{~cm})$.

2.1.1. TR1/I: NEOSSOLO LITÓLICO, solo raso, com seqüência de horizontes $\mathrm{O}$, A e R. O perfil localiza-se na área arenosa, a cerca de $1 \mathrm{~m}$ do contato colina-planície. $O$ lençol freático estava presente a $5 \mathrm{~cm}$ de profundidade.

- Horizonte O: 1-0 cm; material orgânico pouco d ecomposto. Raizes finas abundantes.

- Horizonte A: 0-13 cm; cinzento-escuro (10YR 4/1, seco) e bruno-acinzentado-muitoescuro (10YR 3/2, úmido); arenosa com predomínio de areia fina; estrutura granular, com 3 a $6 \mathrm{~mm}$ de diâmetro, pouco desenvolvida; consistência seca solta e solta quando úmida; não plástica e não pegajosa; presença abundante de raizes finas; porosidade muito abundante, entre agregados e de amontoamento. Torna-se gradativamente mais claro na base, com volumes centimétricos difusos de areia branca, com aumento do diâmetro das areias no contato com a rocha $(13 \mathrm{~cm}+)$.

2.1.2. TR1/I: NEOSSOLO LITÓLICO, solo raso, com seqüência de horizontes $O, A$, Cc e R. O perfil localiza-se na colina, a cerca de $7 \mathrm{~m}$ do contato colina-planície.

- Horizonte O: $1-0 \mathrm{~cm}$; material orgânico composto por folhas mortas, muito fracamente decompostas, juntamente com resíduos vegetais moderadamente decompostos associados a raizes finas abundantes. 
- Horizonte A: 0-7 cm; amarelo (10YR 8/6, seco) e amarelo-brunado (10YR 6/6, úmido); franco-arenosa; estrutura maciça a granular, média, fraca; consistência seca ligeiramente dura e friável quando úmida; ligeiramente plástica e ligeiramente pegajosa; presença comum de raizes finas; porosidade abundante, entre agregados e de amontoamento. Apresentava a porção superior escura, com menos de $1 \mathrm{~cm}$ de espessura. A transição é clara e plana.

- Horizonte Cc: 7-25 cm; bruno-muito-claro-acinzentado (10YR 8/4, seco) e amarelobrunado (10YR 6/6, úmido) franco-argilo-arenosa com cascalho; estrutura maciça; consistência seca ligeiramente dura; friável quando úmida; ligeiramente plástica e ligeiramente pegajosa; porosidade mediamente abundante, tubular. Presença de nódulos e concreções ferruginosos, freqüentes ( 15 a $40 \%$ do volume), pequenos a médios (menor que $1 \mathrm{~cm}$ ), duros, irregulares a esféricos, bruno-avermelhados. O horizonte torna-se progressivamente endurecido na base, com aumento da quantidade de nódulos e concreções, passando para uma alterita coesa de granito.

\subsection{Contato formando um barranco, com afloramento de matacões - TR2:} trincheira com 5 metros de comprimento, abrangendo o material amarelado, argiloarenoso na borda da colina até a porção arenosa na planície (Figura 36). No barranco formado na borda da colina o solo torna-se gradativamente acinzentado até a alterita da rocha. As mudanças texturais e de coloração, entre o solo do barranco junto à colina e o do plano, se dão numa faixa de $1 \mathrm{~m}$, passando de amarelo-oliváceo para tons mais brunos, até tornar-se bruno escuro na porção plana. Os afloramentos de granito estão presentes na superficie do solo na porção plana, na periferia da colina. A rocha aparece na base da trincheira ao longo da planície hidromórfica. Na porção plana o solo é raso, com uma camada de raízes muito densa na superficie.

2.2.1. Borda da colina - TR2/I: LATOSSOLO AMARELO, solo profundo, seqüência de horizontes $\mathrm{O}, \mathrm{A}, \mathrm{BA}, \mathrm{Bw}, \mathrm{BCg}, \mathrm{CBg}$ e $\mathrm{Cg}$. O perfil localiza-se na borda da colina, onde se forma um barranco com cerca de $75 \mathrm{~cm}$ de altura em relação a porção arenosa. O lençol freático estava presente a $90 \mathrm{~cm}$ de profundidade.

- Horizonte O: 1-0 cm; material orgânico parcialmente decomposto. Raizes finas abundantes. A transição é abrupta e plana.

- Horizonte A: 0-3 cm; cinzento-brunado-claro (10YR 6/2, seco) a bruno-acinzentado (10YR 5/2, seco) e bruno-escuro (10YR 4/3, úmido); areia franca com predomínio da fração fina; estrutura grumosa e granular, média a grande (3 a $8 \mathrm{~mm}$ ), fraca; consistência seca muito macia e muito friável quando úmida; não plástica e não pegajosa; presença muito abundante de raizes finas; porosidade muito abundante entre grumos. Volumes milimétricos mais arenosos. Agregados arredondados com 1,0 a 1,2 cm de diâmetro, de coloração bruno escura, formados pelas minhocas. Presença de um cupinzeiro na superficie com formato arredondado, com $18 \mathrm{~cm}$ de altura e $29 \mathrm{~cm}$ de diâmetro, composto por material bruno-amarelado, argilo-arenoso. A transição é abrupta e plana.

- Horizonte BA: $3-25 \mathrm{~cm}$; amarelo $(2.5 \mathrm{Y} 7 / 6$, seco) e amarelo-oliváceo $(2.5 \mathrm{Y} 6 / 8$, úmido); areia franca com predominio de areia fina e média; estrutura maciça e granular, pequena, fraca; consistência seca macia; friável quando úmida; ligeiramente plástica e ligeiramente pegajosa; raizes finas abundantes e algumas raizes médias; porosidade 
mediamente abundante, tubular e de amontoamento. A porção superior é composta por material ligeiramente mais arenoso e frouxo, muito poroso. Pedotúbulos de minhoca abundantes, com cerca de $1,2 \mathrm{~cm}$ de diâmetro, arredondados e orientados verticalmente. O material dos pedotúbulos é bruno-escuro (10YR 4/3, úmido) e bruno-acinzentado (10YR 5/2, seco). As bordas ém bruno-amareladas (10YR5/8 - úmido) e amarelas $(2,5 \mathrm{Y} 7 / 8$ - seco), com cerca de $1 \mathrm{~mm}$ de espessura. A transição é gradual e plana.

- Horizonte Bwl: $25-72 \mathrm{~cm}$; amarelo (2.5Y 8/6, seco) e amarelo-oliváceo (2.5Y 6/8, úmido); franco-arenosa com areia fina e média; maciça e forte, muito pequena, granular; consistência seca macia a ligeiramente dura; muito friável quando úmida; ligeiramente plástica e ligeiramente pegajosa; raízes finas comuns; porosidade abundante, tubular e de amontoamento. A quantidade de pedotúbulos é menor que no horizonte anterior. $\mathrm{O}$ material no interior do pedotúbulo é bruno-escuro (10YR 3/3, úmido) e brunoacinzentado (10YR 5/2, seco). Externamente é circundado por material amarelo-oliváceo (2.5Y 6/6, úmido) e amarelo-muito-claro-acinzentado (10YR 7/3, seco). Esse conjunto com formato arredondado atinge cerca de $4 \mathrm{~cm}$ de diâmetro. As bordas são finas, com 1 a $2 \mathrm{~mm}$ de espessura, compostas por material bruno-amarelado (10YR 5/8, úmido) e amarelo-brunado (10YR 6/8, seco). Há domínios mais claros, com formato arredondado, variando de 3 a $5 \mathrm{~cm}$ de diâmetro, ligeiramente alongados, compostos por material bruno-amarelado (10YR 5/8, úmido) e amarelo-brunado (10YR 6/8, seco). As bordas são semelhantes às do pedotúbulo. Foram encontradas duas concreções ferruginosas arredondadas, com diâmetro de $5 \mathrm{~mm}$, mediamente endurecidas. O material interno é bruno-avermelhado. A transição é gradual e ondulada.

- Horizonte Bw2: 72-105 cm; amarelo-claro-acinzentado (2.5Y 8/4, seco) e brunoamarelado-claro (2.5Y 6/4, úmido); franco-argilo-arenosa com areia média; maciça; consistência seca dura; friável quando úmida; ligeiramente plástica e ligeiramente pegajosa; raízes em menor quantidade que no horizonte anterior; porosidade tubular e de amontoamento menos abundante que no horizonte anterior. Mosqueados amarelobrunados (10YR 6/8, seco) e bruno-amarelados (10YR 5/8, úmido), comuns, de tamanho pequeno a médio (até $15 \mathrm{~mm}$ ) e de contraste proeminente. Algumas manchas ocorrem em torno de canais de raízes. Volumes milimétricos a centimétricos, irregulares e mediamente distintos, amarelo-claro-acinzentado (5Y 7/3, seco) e oliva-claroacinzentado (5Y 6/4, úmido). O tamanho e a abundância destes volumes aumentam do topo para a base do horizonte. A transição é clara e ondulada.

- Horizonte BCg: 105-126 cm; amarelo-claro-acinzentado (5Y 7/3, seco) e oliva-claroacinzentado (5Y 6/4, úmido); franco-arenosa, com areia média e grossa; estrutura maciça; consistência seca dura a muito dura; friável quando úmida; ligeiramente plástica e ligeiramente pegajosa; poucas raízes; porosidade tubular mediamente a pouco abundante. Mosqueados amarelo-brunados (10YR 6/8, seco) e bruno-amarelados (10YR $5 / 8$, úmido), comuns, de contraste proeminente e tamanho médio ( 5 a $15 \mathrm{~mm}$ ), presentes nos domínios com maior macroporosidade. Presença de mica em pequena quantidade, parcialmente decomposta, com coloração amarelada. A transição é clara e ondulada.

- Horizonte CBg: 126-135 cm; cinzento-claro (5Y 7/2, seco) e oliva-claro-acinzentado (5Y 6/4, úmido) a oliva-claro-acinzentado (5Y 6/3, seco) e oliva ( 5 Y $5 / 3$, úmido); franco-arenosa com areia média e grossa; estrutura maciça; consistência seca dura a muito dura; friável a firme quando úmida; ligeiramente plástica e ligeiramente pegajosa; 
poucas raízes; porosidade pouco abundante e tubular. Mosqueados amarelo-brunados (10YR 6/8, seco) e bruno-amarelados (10YR 5/8, úmido), pouco comuns e em maior quantidade na porção superior do horizonte, de tamanho pequeno, menores do que $5 \mathrm{~mm}$ e contraste proeminente. Ocorrem comumente em torno de canais de raízes. Micas parcialmente decompostas, com coloração amarelada. A transição é clara e plana.

- Horizonte $\mathrm{Cg} / \mathrm{R}$ : $135-160 \mathrm{~cm}$; alterita de granito, cinzento-oliváceo-claro (5Y 6/2, seco) e bruno-oliváceo ( $2.5 \mathrm{Y} 4 / 4$, úmido) a cinzento-claro (5Y $7 / 2$, seco) e cinzentobrunado-claro (2.5Y 6/2, úmido); areia franca com fragmentos centimétricos de rocha; friável quando úmida; não plástica e não pegajosa; Micas e feldspatos alterados abundantes. Concreções ferruginosas arredondadas; vermelho-amarelado (5YR 4/8, úmido) e bruno-forte ( $7.5 \mathrm{YR} \mathrm{5/8,} \mathrm{seco)} \mathrm{a} \mathrm{amarelo-brunado} \mathrm{(10YR} \mathrm{6/8,} \mathrm{seco),} \mathrm{poucas} \mathrm{(5}$ a $15 \%$ do volume), com cerca de $1 \mathrm{~cm}$ de diâmetro, fortemente coesas. Pedotúbulos com formato arredondado, com 1,0 a $1,5 \mathrm{~cm}$ de diâmetro, compostos por material brunoescuro, de textura arenosa fina.

\subsubsection{Planície hidromórfica - TR2/II a TR2/IV: NEOSSOLOS} QUARTZARÊNICOS, solo raso, com seqüência de horizontes O, A, Cg e R. Esses solos localizam-se na área arenosa, a partir de $1 \mathrm{~m}$ da borda de colina. O lençol freático estava presente entre 5 e $10 \mathrm{~cm}$ de profundidade.

- Horizonte O: 2-0 cm; material orgânico muito fracamente decomposto. Raízes finas abundantes. A transição é abrupta e plana.

- Horizonte A: 0-25 cm; bruno-acinzentado (10YR 5/2, seco) e bruno-acinzentadoescuro (10YR 4/2, úmido); arenosa, com predomínio de areia fina; estrutura grumosa e granular, média, fraca; consistência seca muito macia e muito friável quando úmida; não plástica e não pegajosa; raizes finas, médias e grossas muito abundantes formando um tapete; porosidade muito abundante, entre grumos e entre as raizes. Alguns volumes milimétricos de areia branca na porção inferior. A transição é abrupta e plana.

- Horizonte Cg: $25-65 \mathrm{~cm}$; branco (10YR 8/2, seco) e cinzento-brunado-claro (10YR $6 / 2$, úmido); arenosa, com predomínio de areia média a grossa e cascalho; estrutura em grãos simples; consistência seca e úmida solta; não plástica e não pegajosa; raízes finas e médias comuns. Esse material arenoso está localizado sobre a rocha (granito), a mais de $65 \mathrm{~cm}$ de profundidade.

2.3. Contato com desnível gradual e rocha mais profunda - TR3: trincheira com 6 metros de comprimento, partindo do material amarelado na borda da colina até a porção arenosa sob hidromorfia (Figura 37). Na borda da colina foi descrito um perfil de solo amarelado, com textura média. Este perfil toma-se gradativamente acinzentado até a alterita da rocha. As mudanças texturais e de coloração, entre o solo do barranco junto à colina e o da planície, se dão numa faixa de $5 \mathrm{~m}$. A rocha encontra-se na base da trincheira, em profundidade de 70 a $180 \mathrm{~cm}$.

2.3.1. Borda da colina - TR3/I: GLEISSOLO HÁPLICO, solo profundo, seqüência de horizontes $\mathrm{O}, \mathrm{A}, \mathrm{BA}, \mathrm{Bi}, \mathrm{BCg}, \mathrm{CBg}$ e $\mathrm{Cg}$. O perfil localiza-se na borda da colina, com lençol freático a $95 \mathrm{~cm}$ de profundidade. 
- Horizonte O: 1-0 cm; material orgânico parcialmente decomposto. Raízes finas abundantes. A transição é abrupta e plana.

- Horizonte A: 0-9 cm; bruno-acinzentado (2.5Y 5/2, seco) e bruno-acinzentado-muitoescuro (2.5Y 3/2, úmido); franco-argilo-arenosa com predomínio da fração fina; estrutura grumosa e granular, média ( 3 a $5 \mathrm{~mm}$ ), fraca; consistência seca macia e friável quando úmida; não plástica e não pegajosa; presença abundante de raízes finas; porosidade muito abundante entre grumos. Volumes milimétricos amarelados e mais argilosos. A transição é abrupta e plana.

- Horizonte BA: $9-25 \mathrm{~cm}$; amarelo $(2.5 \mathrm{Y} \mathrm{8/8,} \mathrm{seco)} \mathrm{e} \mathrm{amarelo-brunado} \mathrm{(10YR} \mathrm{6/8,}$ úmido); franco-argilo-arenosa com predomínio de areia fina e média; estrutura maciça e blocos subangulares, pequena, fraca; consistência seca ligeiramente dura; friável quando úmida; ligeiramente plástica e ligeiramente pegajosa; raízes finas comuns; porosidade mediamente abundante, tubular. A transição é gradual e plana.

- Horizonte Bi: $25-60 \mathrm{~cm}$; amarelo (10YR 8/8, seco) e amarelo-brunado (10YR 6/8, úmido); franco-argilo-arenosa com predomínio de areia fina e média; estrutura maciça e blocos subangulares, pequena, fraca; consistência ligeiramente dura; friável quando úmida; ligeiramente plástica e ligeiramente pegajosa; raízes finas comuns; porosidade abundante, tubular. A transição é gradual e plana.

- Horizonte BCg: 60-85 cm; amarelo (10YR 8/8, seco) e amarelo-brunado (10YR 6/8, úmido); franco-argilo-arenosa, com areia média; estrutura maciça e blocos subangulares, pequena, fraca; consistência seca ligeiramente dura; friável quando úmida; ligeiramente plástica e ligeiramente pegajosa; poucas raizes; porosidade tubular pouco abundante. Mosqueados vermelhos (2.5YR 5/8, úmido) e amarelo-avermelhados (5YR 6/8, seco), comuns, de contraste proeminente, tamanho pequeno a médio (até $15 \mathrm{~mm}$ ). Nódulos gibbsíticos e ferruginosos, poucos (5 a $15 \%$ do volume), milimétricos, duros, irregulares, amarelo-avermelhados e brancos. A transição é gradual e plana.

- Horizonte CBg: 85-120 cm; amarelo (2.5Y 8/4, seco) e amarelo-oliváceo (2.5Y 6/6, úmido) franco-arenosa com areia grossa e cascalho; estrutura maciça; consistência seca dura; friável quando úmida; não plástica e não pegajosa; poucas raízes; porosidade pouco abundante, tubular. Mosqueados amarelo-avermelhados (5YR 6/8, seco) e vermelhos (2.5YR 5/8, úmido), comuns, de contraste proeminente, tamanho médio ( 5 a $15 \mathrm{~mm}$ ). Nódulos gibbsíticos e ferruginosos, poucos (5 a $15 \%$ do volume), pequenos a médios, duros, amarelo-avermelhados e brancos. A transição é gradual e plana.

- Horizonte Cg: 120-180 cm; amarelo-claro-acinzentado (5Y 8/3, seco) e amarelooliváceo (2.5Y 6/6, úmido) a branco (5Y $8 / 2$, seco) e oliva-claro-acinzentado (5Y 6/4, úmido); arenosa, cascalhento; estrutura litológica; consistência seca dura, firme quando úmida; não plástica e não pegajosa. No topo do horizonte $(100 \mathrm{a} 120 \mathrm{~cm})$ são observados mosqueados vermelhos (2.5YR 4/8, úmido) e vermelho-claros $(2.5 \mathrm{YR} 6 / 8$, seco), poucos, de contraste proeminente, pequenos (até $5 \mathrm{~mm}$ ). Nódulos gibbsíticos e ferruginosos, poucos ( 5 a $15 \%$ do volume), pequenos e médios (até $2 \mathrm{~cm}$ de diâmetro), duros, irregulares, amarelo-avermelhados e brancos.

2.3.2. Planície hidromórfica - TR3/III: NEOSSOLO QUARTZARÊNICO, solo raso, com seqüência de horizontes $\mathrm{O}, \mathrm{A}, \mathrm{Cg}$ e R. O perfil localiza-se na porção arenosa, a $6 \mathrm{~m}$ do contato colina-plano. $O$ lençol freático estava presente a $10 \mathrm{~cm}$ de profundidade. 
- Horizonte O: 1-0 cm; material orgânico fracamente decomposto. Raízes finas abundantes. A transição é abrupta e plana.

- Horizonte A: 0-28 cm; bruno-claro-acinzentado (10YR 6/3, seco) e brunoacinzentado-escuro (10YR 4/2, úmido); arenosa, com predomínio de areia fina; estrutura maciça e granular, grande, fraca; consistência seca macia, muito friável quando úmida; não plástica e não pegajosa; raízes finas e médias abundantes; porosidade muito abundante, entre agregados. Alguns volumes milimétricos de areia branca na porção inferior. A transição é abrupta e plana.

- Horizonte Cg: $28-70 \mathrm{~cm}$; branco (10YR 8/1, seco) e cinzento-brunado-claro (10YR $6 / 2$, úmido); arenosa, com predomínio de areia média, passando para grossa e cascalho em direção a base do horizonte; estrutura em grãos simples; consistência seca e úmida solta; não plástica e não pegajosa; raizes finas e médias comuns. Material presente sobre a rocha (granito), que se dispõe a mais de $70 \mathrm{~cm}$ de profundidade.

\section{Solos da planície hidromórfica}

3.1. Solo com horizonte Bh endurecido - P1: ESPODOSSOLO CÁRBICO, solo profundo, com montículos biológicos superficiais e seqüência de horizontes $\mathrm{O}, \mathrm{A}, \mathrm{E}, \mathrm{Bh}$, $\mathrm{BhC}$ e Cgr. O perfil localiza-se na área arenosa a cerca de $7 \mathrm{~m}$ do contato colinaplanície. O lençol freático estava presente a $18 \mathrm{~cm}$ de profundidade (Figura 38).

- Montículos biológicos superficiais: cinzento-brunado-claro (10YR 6/2, seco) a brunoacinzentado (10YR 5/2, seco) e bruno-acinzentado muito escuro (10YR 3/2, úmido); arenosa, com predomínio de areia fina; volumes milimétricos de areia branca. Apresenta fragmentos vegetais parcialmente decompostos. A estrutura é formada por agregados granulares muito grandes $(1,0$ a $1,2 \mathrm{~cm})$, fracamente desenvolvidos. Internamente $\mathrm{o}$ material tem aspecto maciço. Cada montículo apresenta internamente um canal vertical de circulação do animal, com cerca de $5 \mathrm{~mm}$ de diâmetro, com as paredes bruno escuras. A consistência seca é macia e muito friável quando úmida; ligeiramente plástica e ligeiramente pegajosa. A porosidade é muito abundante, tubular e entre agregados. Os montículos são desgastados pela ação da chuva, ocasionando depósitos de areia branca, formando camadas milimétricas que recobrem as folhas mortas na base. A porção inferior normalmente é colonizada por raizes finas.

- Horizonte 0: 2-0 cm; material orgânico composto por folhas muito fracamente decompostas. Raízes finas abundantes. A transição é abrupta e plana.

- Horizonte A: 0-21 cm; bruno-acinzentado (10YR 5/2, seco) a bruno-amarelado (10YR $5 / 4$, seco) e bruno-escuro (10YR 4/3, úmido) a bruno-amarelado-escuro (10YR 3/4, úmido); arenosa com predomínio de areia fina. Fragmentos vegetais milimétricos, ligeiramente decompostos são observados. A estrutura é grumosa e granular grande a muito grande, com grumos com 0,5 a $1,2 \mathrm{~cm}$ de diâmetro, fracamente desenvolvida; consistência seca muito macia, muito friável quando úmida; ligeiramente plástica e ligeiramente pegajosa; raizes finas e médias muito abundantes; porosidade muito abundante, entre grumos, tubular e de amontoamento. Volumes milimétricos de areia branca, com 2 a $8 \mathrm{~mm}$, irregulares. A transição é clara e plana.

- Horizonte E: 21-73 cm; branco (10YR 8/2, seco) e cinzento-brunado-claro (10YR 6/2, úmido); arenosa, com predomínio de areia fina e média na parte superior, passando para 
areia média e grossa na porção inferior; estrutura em grãos simples; consistência seca solta; solto quando úmida; não plástica e não pegajosa; presença mais abundante de raizes médias, com 3 a $5 \mathrm{~mm}$ de diâmetro; porosidade abundante de amontoamento. A transição é clara e ondulada.

- Horizonte Bh: 73-110 cm; bruno-escuro (10YR 4/3, seco) e bruno-muito-escuro (10YR $2 / 2$, úmido); arenosa com areia média e grossa; estrutura maciça; consistência seca ligeiramente dura a dura; friável a firme quando úmida; não plástica e ligeiramente pegajosa; raizes de diâmetro médio pouco comuns, a maioria já mortas e parcialmente decompostas; porosidade pouco abundante, tubular. No topo do horizonte há alguns volumes milimétricos com orientação vertical, com 5 a $7 \mathrm{~mm}$ de diâmetro, preenchidos com areia fina. A zona de transição com o horizonte $\mathrm{E}$ tem coloração mais clara, apresentando volumes milimétricos a centimétricos arredondados e difusos, compostos por material bruno-escuro. Abaixo da zona de transição estes volumes coalescem formando uma matriz bruno muito escura uniforme. Cerosidade pouco abundante relacionada principalmente aos canais radiculares, de natureza orgânica, com coloração bruno muito escuro brilhante quando úmido. A cerosidade torna-se mais abundante em profundidade. Litorrelíquias de granito com 5 a $6 \mathrm{~cm}$, arredondadas com uma camada bruno muito escura endurecida na porção superior, com 2 a $3 \mathrm{~mm}$ de espessura. A transição é gradual e plana.

- Horizonte BhC: 110-130 cm; bruno-amarelado (10YR 5/4, seco) e bruno-escuro (10YR 3/3, úmido); arenosa a areia franca com areia média e grossa; estrutura maciça; consistência seca ligeiramente dura; friável a firme quando úmida; não plástica e ligeiramente pegajosa a não pegajosa; raizes em menor quantidade que no horizonte anterior, com diâmetro médio. Predomínio de raízes mortas e parcialmente decompostas; porosidade pouco abundante, tubular. Há volumes milimétricos a centimétrios irregulares, compostos por material mais claro, bruno muito claro acinzentado (10YR $7 / 3$, seco) e bruno-amarelado (10YR 5/4, úmido). A cerosidade de natureza orgânica ocorre em pequena quantidade, principalmente nos canais radiculares, com coloração bruno muito escuro brilhante quando úmido. Mica amarelada parcialmente decomposta nos domínios bruno-amarelados. A transição é gradual e plana.

- Horizonte Cgr: 130-150 cm+; matriz manchada, bruno-muito-claro-acinzentado (10YR $7 / 3$, seco) e bruno-claro-acinzentado (10YR 6/3, úmido) a cinzento-oliváceo ( $5 \mathrm{Y} 5 / 2$, seco) e oliva (5Y 4/3, úmido); franco-arenosa, com areia média e grossa; estrutura maciça; consistência seca ligeiramente dura; friável quando úmida; não plástica e ligeiramente pegajosa; poucas raizes, de diâmetro médio e decompostas; porosidade pouco abundante, tubular. A cerosidade de natureza orgânica ocorre em pequena quantidade, principalmente nos canais radiculares, com coloração bruno muito escuro brilhante quando úmido. Mica amarelada parcialmente decomposta e minerais pseudomorfos, com coloração bruno-claro-acinzentada.

3.2. Solo com areia branca sobre a rocha - P2: NEOSSOLO QUARTZARÊNICO, solo pouco profundo, com montículos biológicos superficiais e sequeência de horizontes $\mathrm{O}, \mathrm{A}, \mathrm{Cg}$ e R. O perfil localiza-se na área arenosa, entre P1 e o contato com a colina, a cerca de 3,5 m do contato colina-planície. $O$ lençol freático estava presente a $10 \mathrm{~cm}$ de profundidade. 
- Montículos biológicos superficiais e horizonte $\mathrm{O}$ : semelhantes aos do perfil anterior.

- Horizonte A: 0-16 cm; bruno-acinzentado (10YR 5/2, seco) e bruno-acinzentadoescuro (10YR 5/2, úmido). A morfologia é semelhante ao horizonte A do perfil anterior (P1). A transição é clara e plana.

- Horizonte Cg: $16-90 \mathrm{~cm}$; branco (2.5Y 8/0, seco) e cinzento (5Y 5/1, úmido). A morfologia é semelhante ao horizonte E do perfil P1. Destaca-se pela grande quantidade de raízes na porção superior do horizonte. $\mathrm{O}$ material arenoso deposita-se diretamente sobre a rocha $(90 \mathrm{~cm}+)$.

3.3. Solo com horizonte Bh não endurecido - P3: ESPODOSSOLO CÁRBICO, solo profundo, com montículos biológicos superficiais e seqüência de horizontes $\mathrm{O}, \mathrm{A}, \mathrm{E}$, $\mathrm{E} / \mathrm{Bh}$ e $\mathrm{Cg}$. O perfil localiza-se na área arenosa a cerca de $15 \mathrm{~m}$ do contato colina-plano. O lençol freático estava presente a $12 \mathrm{~cm}$ de profundidade (Figura 39). As características morfológicas deste perfil são semelhantes aos perfis P4 e P5.

- Montículos biológicos superficiais: semelhantes aos presentes em P1.

- Horizonte O: 2-0 cm; material orgânico composto por folhas muito fracamente decompostas. Raízes finas abundantes. A transição é abrupta e plana.

- Horizonte A: 0-18 cm; bruno-acinzentado (10YR 5/2, seco) e bruno-acinzentadomuito-escuro (10YR 3/2, úmido); arenosa com predomínio de areia fina, apresentando fragmentos vegetais milimétricos, ligeiramente decompostos. A estrutura é grumosa e granular, grande, fraca; consistência seca muito macia, solta quando úmida; não plástica e não pegajosa; raízes finas e médias muito abundantes; porosidade muito abundante, entre grumos e tubular. Volumes milimétricos de areia branca. A transição é clara e plana.

- Horizonte E: $18-105 \mathrm{~cm}$; branco (2.5Y 8/0, seco) e cinzento (5Y 5/1, úmido); arenosa, com predomínio de areia fina e média na parte superior, com maior quantidade de areia grossa em profundidade; estrutura em grãos simples; consistência seca solta; solta quando úmida; não plástica e não pegajosa; raízes médias abundante, com 3 a $5 \mathrm{~mm}$ de diâmetro; porosidade abundante de amontoamento. A transição é clara e plana.

- Horizonte E/Bh: 105-150 cm; bruno-acinzentado (10YR 5/2, seco) a bruno-escuro (10YR 4/3, seco) e bruno-acinzentado-escuro (10YR 4/2, úmido) a bruno-acinzentadomuito-escuro (10YR 3/2, úmido). Os domínios escurecidos e enriquecidos em matéria orgânica são milimétricos a centimétricos, com até $1 \mathrm{~cm}$ de diâmetro. A quantidade deste material aumentava do topo para a base do horizonte; arenosa com areia fina a grossa; estrutura em grãos simples e maciça; consistência seca solta; solta quando úmida; não plástica e não pegajosa; raízes de diâmetro médio pouco comuns, a maioria já mortas e parcialmente decompostas; porosidade abundante de amontoamento. A transição é gradual e plana.

- Horizonte Cg: $150-180 \mathrm{~cm}+$; branco $(2.5 \mathrm{Y} 8 / 2$, seco) e cinzento claro $(2.5 \mathrm{Y} 7 / 2$, úmido); arenosa a franco arenosa; estrutura maciça; consistência seca ligeiramente dura; friável quando úmida; ligeiramente plástica e ligeiramente pegajosa; raízes raras; porosidade pouco abundante, tubular. 


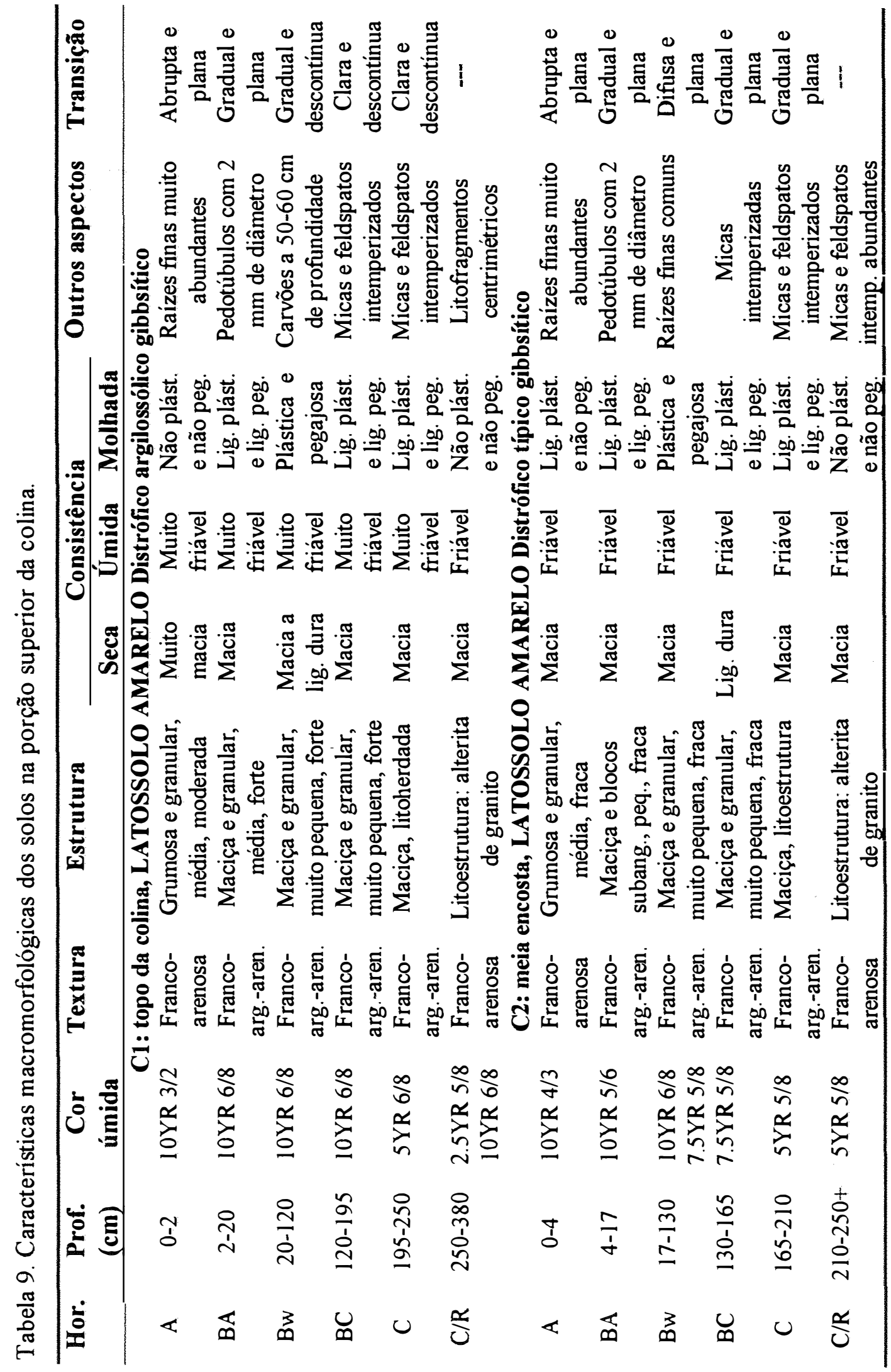




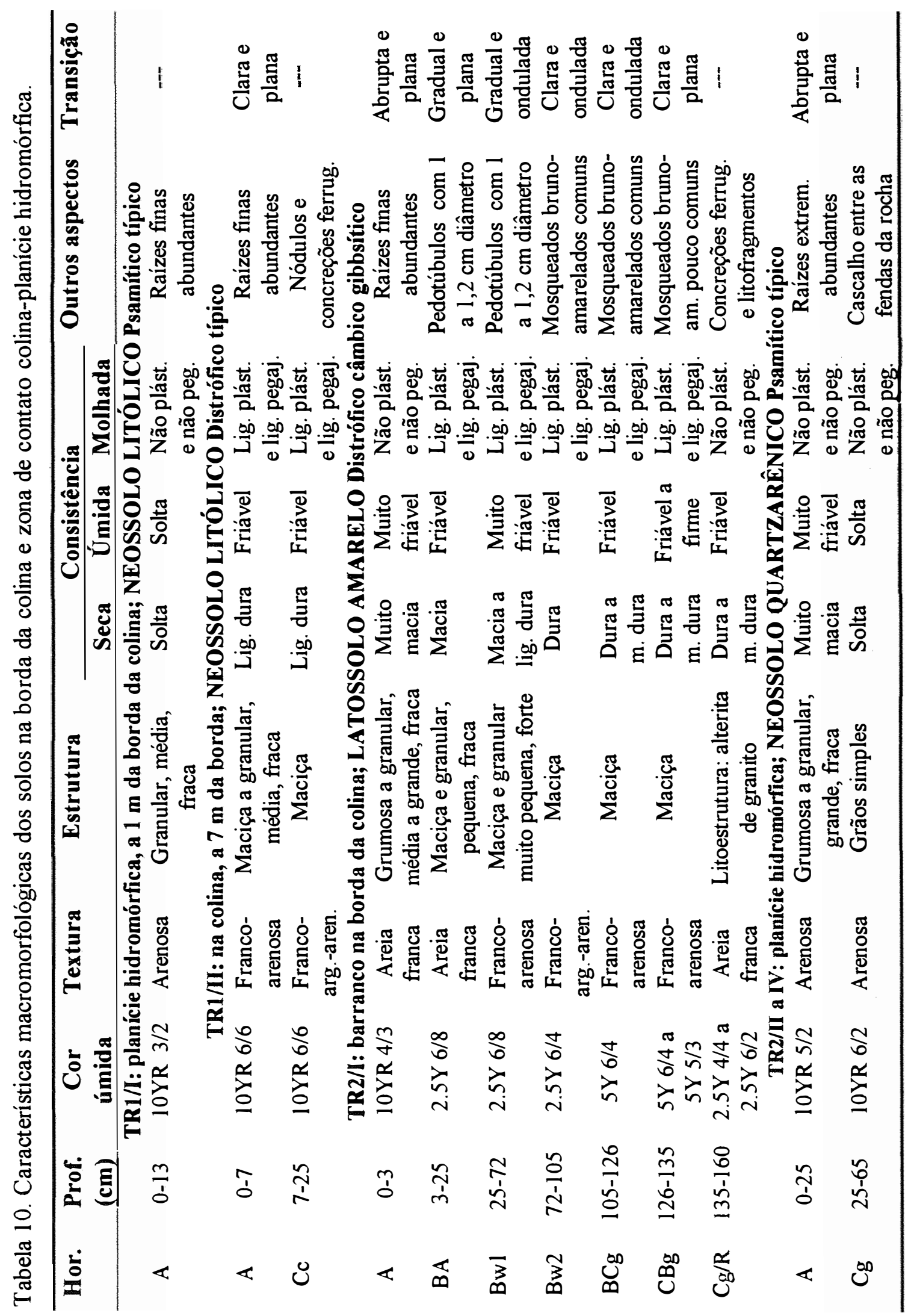




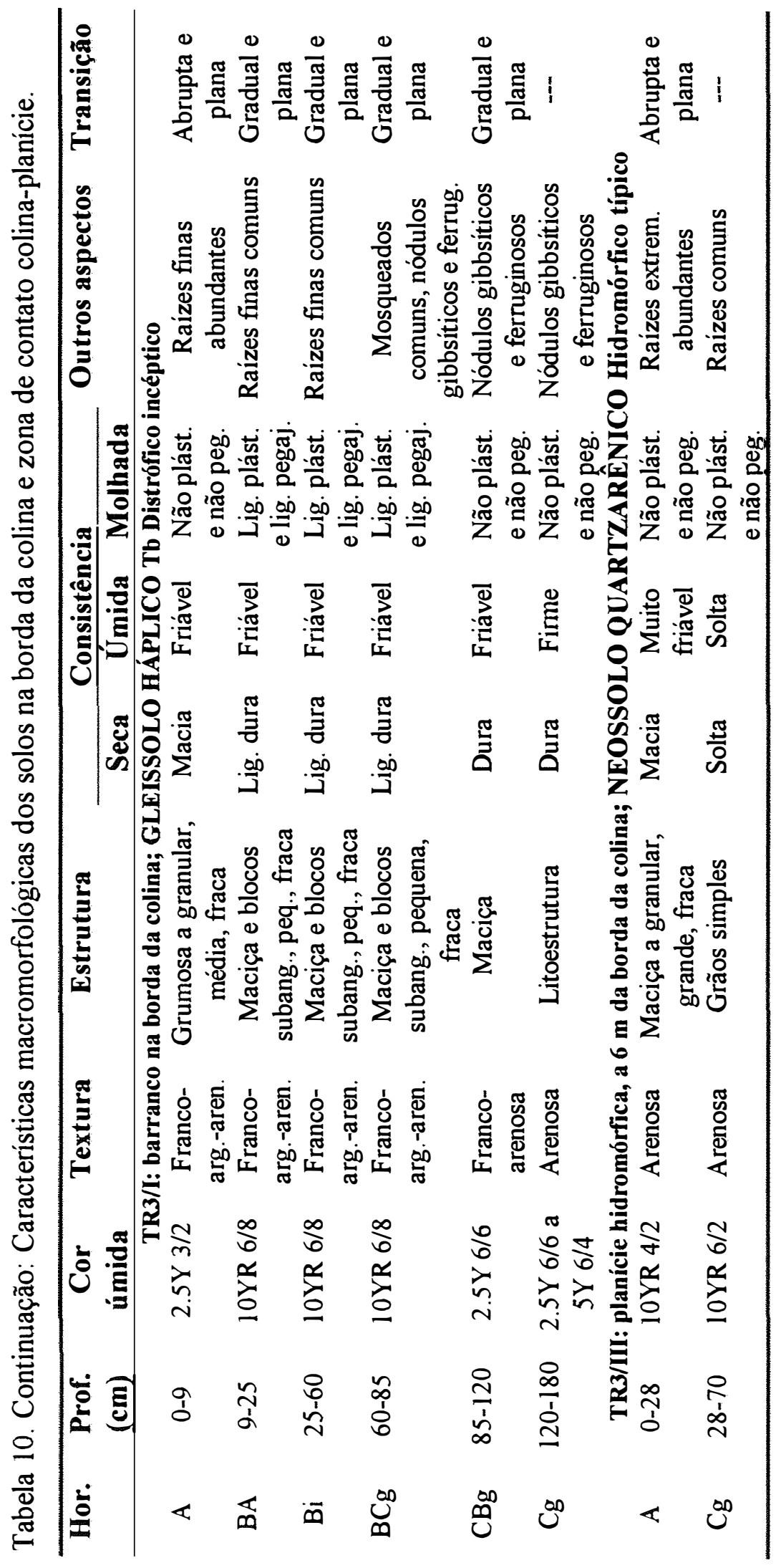




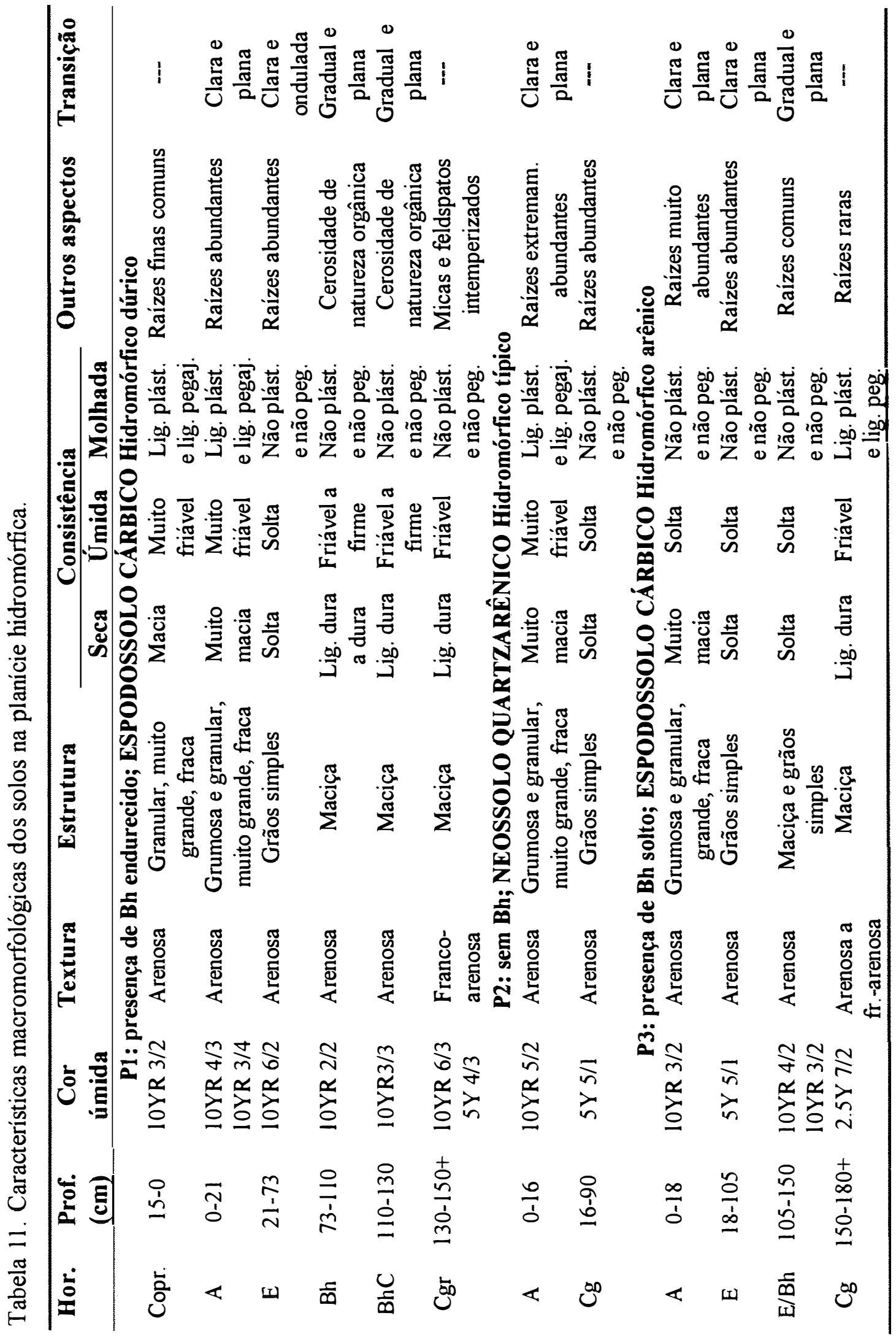




\section{Legenda}

No Serapilheira

Hor. A: bruno-acinzentado-muito-escuro (10YR 3/2); franco-arenosa; granular

IIII Hor. BA: amarelo-brunado (10YR 6/8); franco-argilo-arenosa; granular

Hor. Bw: amarelo-brunado (10YR 6/8); argilo-arenosa; maciça e forte muito pequena granular

证 Hor. BC: amarelo-brunado a amareloavermelhado; argilo-arenosa com cascalho; maciça e forte muito pequena granular

国 Hor. C: vermelho a amarelo-brunado; franco-argilo-arenosa com cascalho e fragmentos de rocha

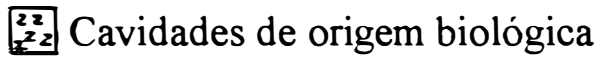
Franito

] Amostras para análises fisicas, químicas e mineralógicas

(1) Amostras indeformadas

$==$ Nível do lençol freático

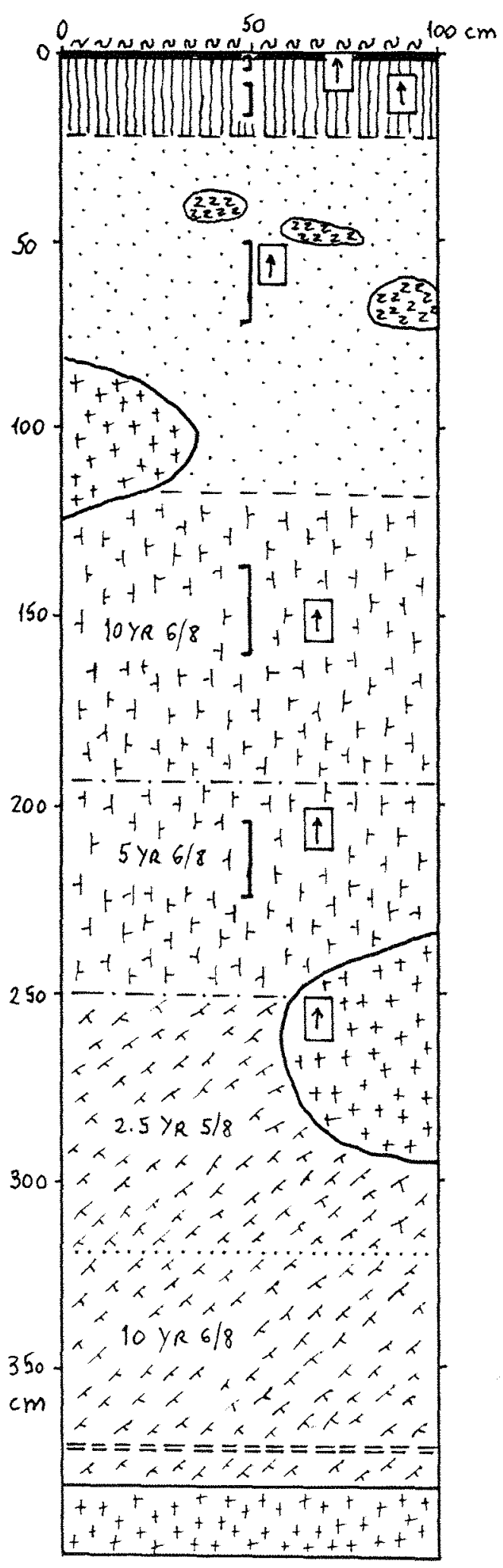

Figura 34 - Aspecto morfológico do perfil Cl, LATOSSOLO AMARELO, no topo da colina, com representação dos horizontes pedológicos e localização dos locais de amostragem. 
Legenda

No Serapilheira

Hor. A: bruno-escuro (10YR 4/3); francoarenosa; granular

[III Hor. BA: bruno-amarelado (10YR 5/6); franco-arenosa; granular

Hor. Bw: amarelo-brunado (10YR 6/8) e bruno-forte (7.5YR 5/8); franco-argiloarenosa; maciça e forte muito pequena granular

国 Hor. BC: bruno-forte (7.5YR 5/8); franco-argilo-arenosa com cascalho; maciça e forte muito pequena granular

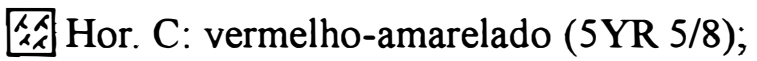
franco-argilo-arenosa com cascalho e fragmentos de rocha

22.

Litorrelíquias de granito

1 Amostras para análises fisicas, químicas e mineralógicas

(1) Amostras indeformadas

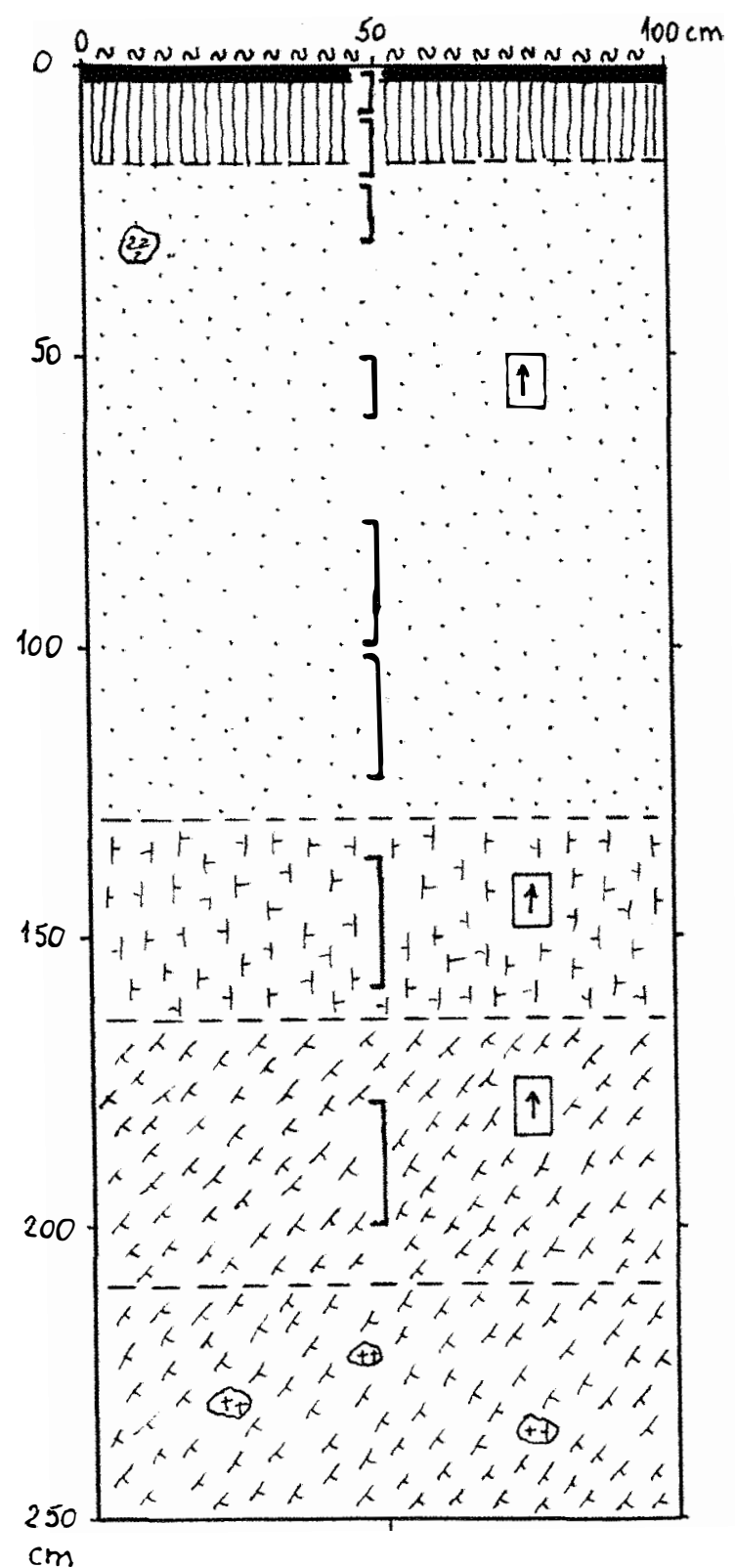

Figura 35 - Aspecto morfológico do perfil C2, LATOSSOLO AMARELO, em meia encosta na colina, com representação dos horizontes pedológicos e localização dos locais de amostragem. 

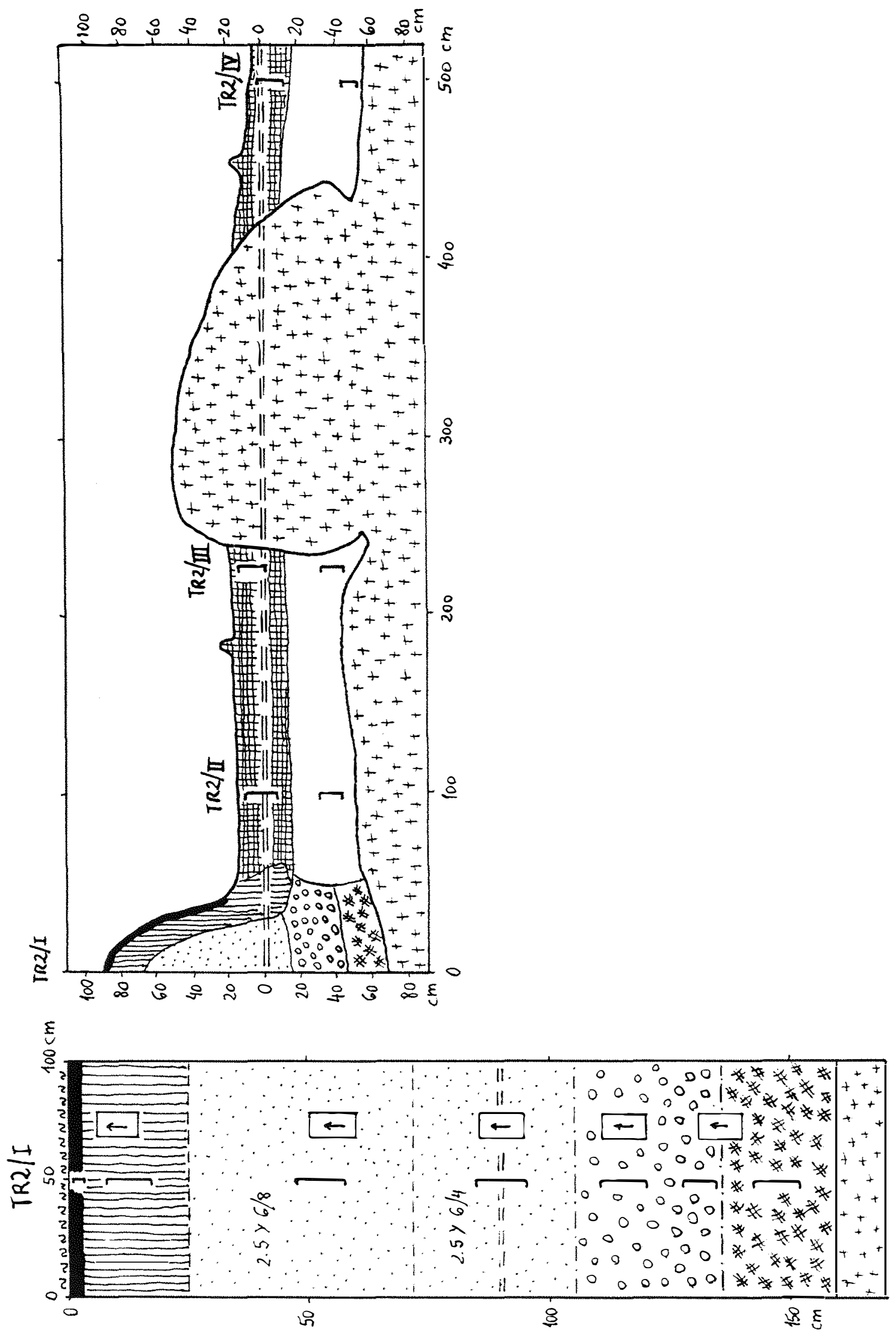


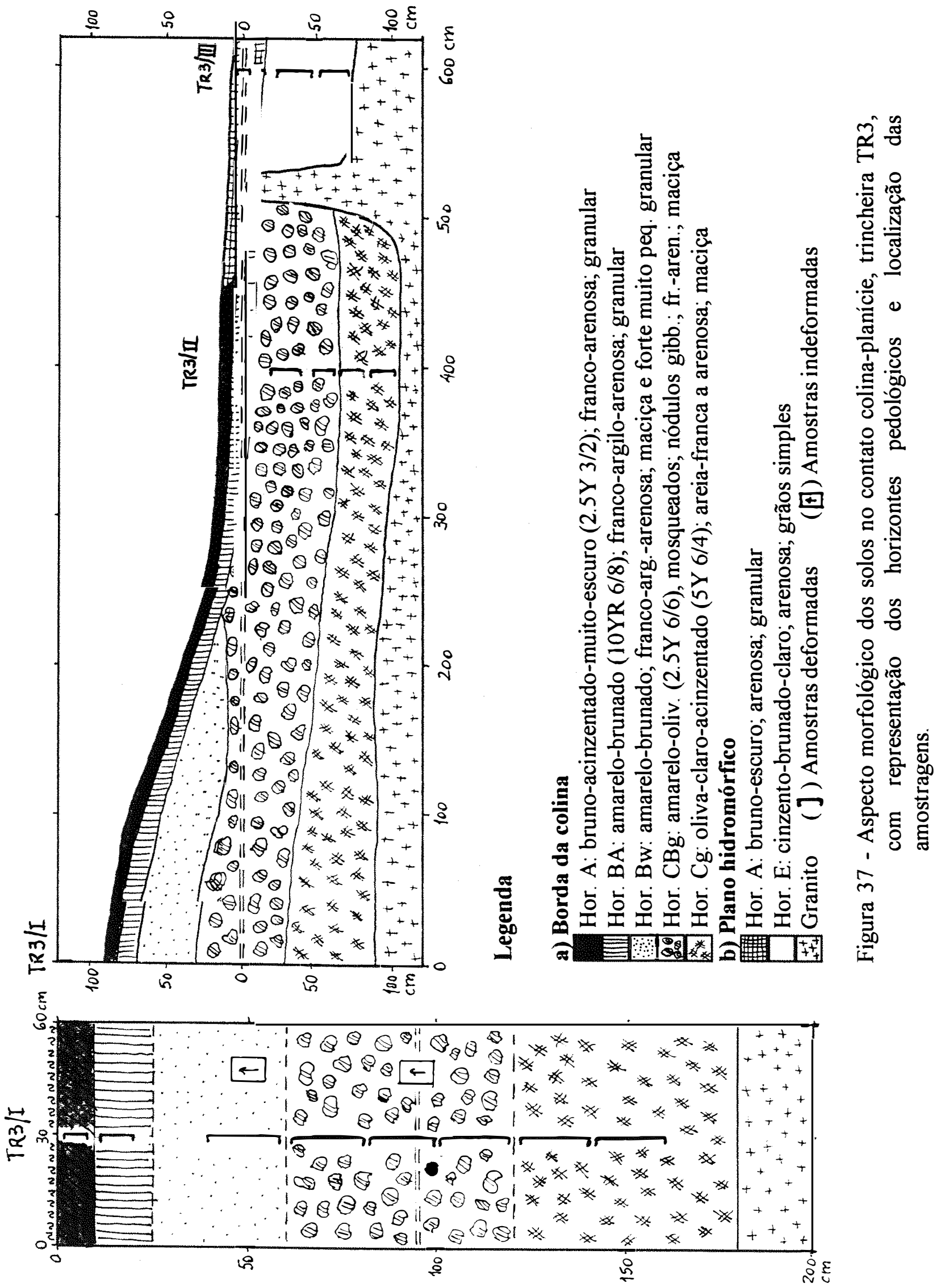




\section{Legenda}

网 bruno-acinzentado-muito-escuro (10YR

3/2); arenosa; granular (Montículos de minhoca)

Hor. A: bruno-escuro (10YR 4/3); arenosa; granular

$\square$ Hor. E: cinzento-brunado-claro (10YR 6/2); arenosa; grãos simples

Hor. Bh endurecido: bruno-muito-escuro (10YR 2/2); arenosa; maciça

[1] Hor. BhC: bruno-escuro (10YR 3/3); arenosa; maciça

WMI Hor. Cgr: bruno-claro-acinzentado (10YR 6/3) e cinzento-oliváceo (5Y 5/2), manchado; franco-arenosa; maciço

Litorrelíquias de granito

] Amostras para análises físicas, químicas e mineralógicas

1. Amostras indeformadas

$==$ Nivel do lençol freático

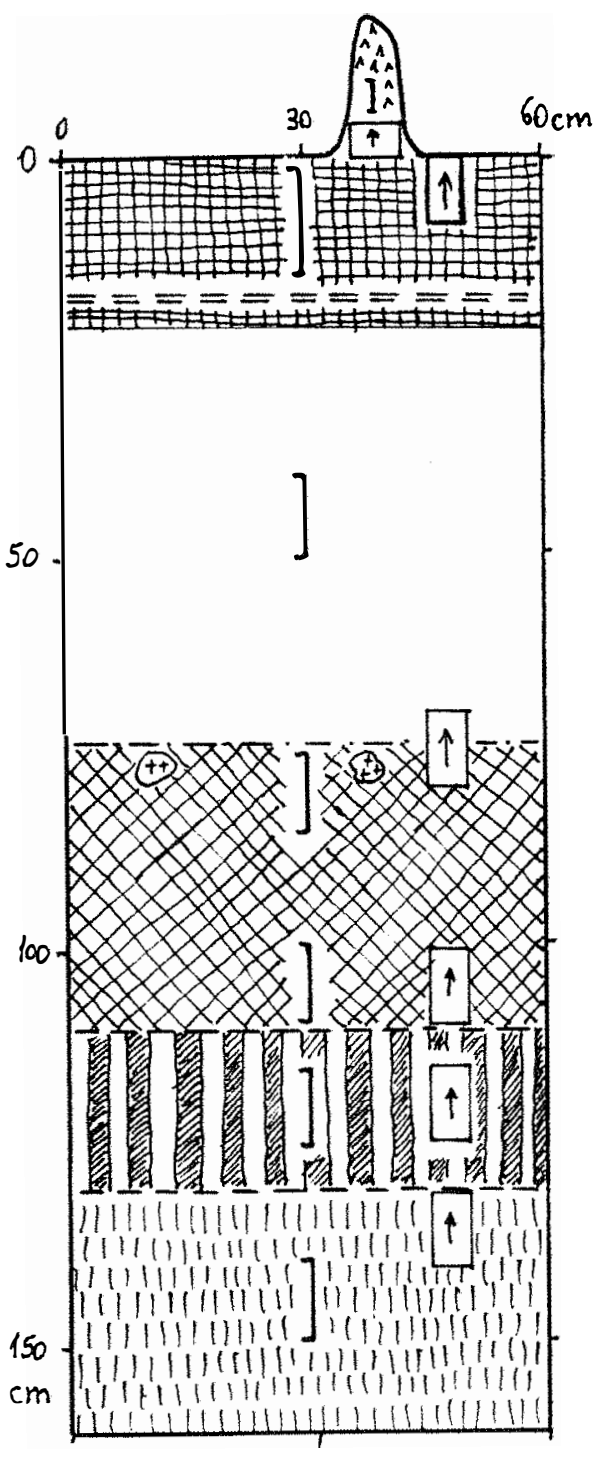

Figura 38 - Aspecto morfológico do perfil P1, ESPODOSSOLO CÁRBICO, na planície hidromórfica, com representação dos horizontes pedológicos e localização dos locais de amostragem. 


\section{Legenda}

金 Bruno-acinzentado-muito-escuro (10YR 3/2); arenosa; granular (Montículos de minhoca)

Hor. A: bruno-acinzentado-muito-escuro (10YR 3/2); arenosa; granular

$\square$ Hor. E: cinzento (5Y 5/1); arenosa; grãos simples

Hor. E/Bh: bruno-acinzentado-escuro (10YR 4/2) a bruno-acinzentado-muitoescuro (10YR 3/2); arenosa; maciça

恧 Hor. Cg: cinzento-claro (2.5Y 7/2); arenosa a franco-arenosa; maciça ()

] Amostras para análises físicas, químicas e mineralógicas

田 Amostras indeformadas

$==$ Nível do lençol freático

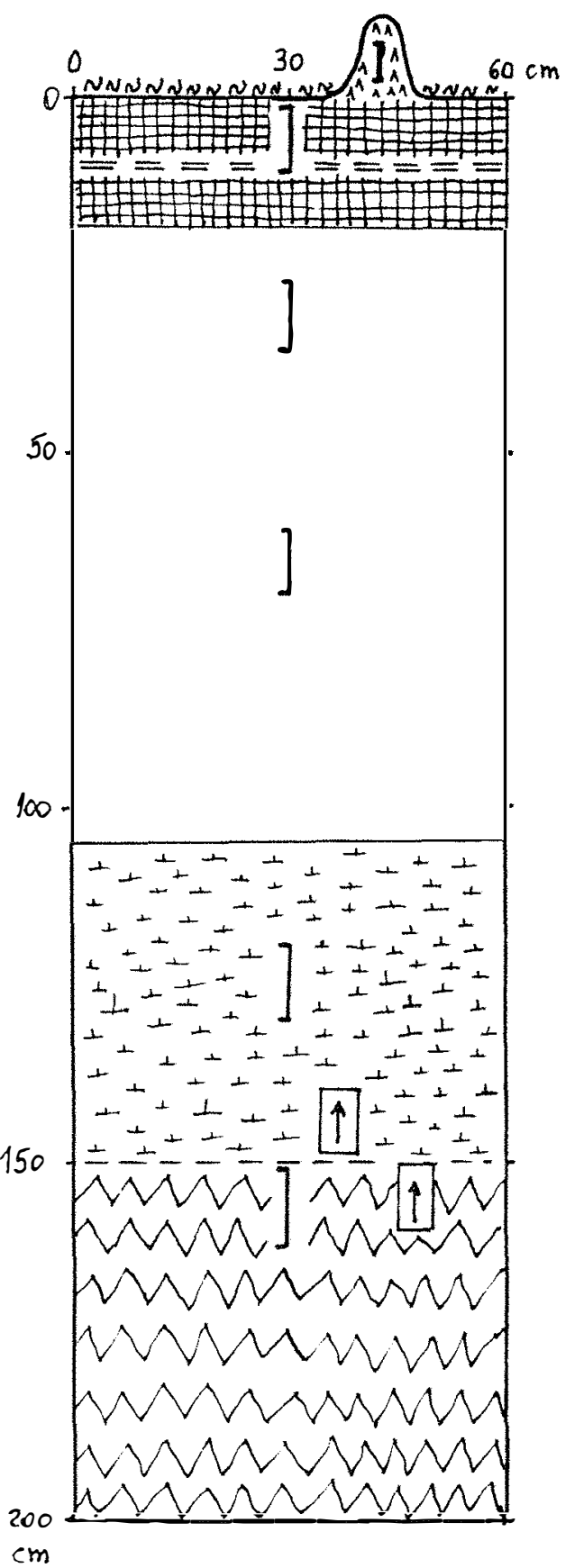

Figura 39 - Aspecto morfológico do perfil P3, ESPODOSSOLO CÁRBICO, na planície hidromórfica, com representação dos horizontes pedológicos e localização dos locais de amostragem. 


\section{ANEXO B}

Descrição meso e micromorfológica dos perfis estudados 


\section{DESCRIÇÃO MESO E MICROMORFOLÓGICA DOS PERFIS ESTUDADOS}

A caracterização meso e micromorfológica detalhada dos solos foi efetuada em seis perfis. Na colina foram descritos um perfil no topo (C1) e outro em meia-encosta (C2), (Tabela 12). No contato colina-planície foram descritos dois perfis, localizados no barranco na borda da colina (TR2/I e TR3/I), (Tabela 13). Na planície hidromórfica foram caracterizados dois perfis (Tabela 14), sendo um com presença de horizonte $B h$ endurecido (P1) e outro com Bh solto (P3).

\section{Solos da colina}

\subsection{Topo da colina - C1: LATOSSOLO AMARELO}

- Horizontes A/BA, 0-10 cm: a parte superior da amostra é bruno-escura, com raízes finas $(0,5 \mathrm{a} 1 \mathrm{~mm})$ abundantes e fragmentos vegetais parcialmente decompostos. A estrutura é grumosa mediamente desenvolvida, com agregados de 1 a $2 \mathrm{~mm}$ de diâmetro na porção superior. Na porção inferior os agregados são mais amarelados, nítidos e enriquecidos em plasma, atingindo 3 a $4 \mathrm{~mm}$ de diâmetro. A porção intermediária apresenta domínios milimétricos mais arenosos. O plasma é bruno-escuro no topo, com matéria orgânica, passando para bruno-amarelado na base. A estrutura plásmica é argilassépica. $\mathrm{O}$ esqueleto é composto por grãos de quartzo, predominando a fração areia fina. A distribuição relativa é intertéxtica a porfirogrânica. Os vazios são do tipo cavidades entre agregados, muito abundantes (50 a 60\%). As pelotas fecais são ocasionais (5\%) na porção superior da amostra. Apresentam formato arredondado, com superficie lisa e de 0,2 a $0,6 \mathrm{~mm}$ de diâmetro. São escuras e desprovidas de esqueleto.

- Horizonte BA, 7-17 cm: o material é mais argiloso que o anterior. A estrutura é composta, granular e maciça. Os agregados têm de 2 a $8 \mathrm{~mm}$ de diâmetro e são enriquecidos em plasma. O plasma é argiloso, bruno-amarelado a amarelo-brunado. A estrutura plásmica é isotrópica a argilassépica. $\mathrm{O}$ esqueleto é formado por quartzo, com predomínio de areia fina. Partículas de mica e feldspatos parcialmente intemperizados aparecem em pequena quantidade. A distribuição relativa é intertéxtica a porfirogrânica. Os vazios são predominantemente compostos por poros tubulares e cavidades intergranulares. As raízes finas são abundantes. Alguns fragmentos vegetais em decomposição.

- Horizonte Bw, 50-60 cm: matriz amarelada uniforme, com domínios milimétricos e irregulares mais ricos em plasma, pouco nítidos, constituindo pseudomorfos de feldspatos. A estrutura é composta, maciça e granular muito pequena, mediamente desenvolvida, com agregados de 0,3 a $0,5 \mathrm{~mm}$ de diâmetro. Há agregados arredondados com 1 a $3 \mathrm{~mm}$ de diâmetro, pouco nítidos e pouco comuns. O plasma é argiloso, com estrutura plásmica isotrópica a argilassépica. $\mathrm{O}$ esqueleto mostra predomínio de quartzo, principalmente areia fina. Micas intemperizadas amareladas e feldspatos ocorrem em pequena quantidade. A distribuição relativa é porfirogrânica. Um fragmento de carvão centimétrico foi observado, apresentando faixas longitudinais alternadas brilhantes e foscas. Os vazios mais abundantes são os poros tubulares na porção maciça e cavidades 
intergranulares na porção microagregada. As feições pedológicas são pedotúbulos cilindricos, com 1,5 a $2 \mathrm{~mm}$ de diâmetro. O material interno é mais poroso, com estrutura microagregada. As paredes são pouco nítidas. As raizes finas são comuns.

- Horizonte BC, 150-160 cm: maior quantidade de cascalho em relação a amostra anterior. Presença de volumes milimétricos adensados bruno-claros, compostos por minerais pseudomorfos. A estrutura é composta, maciça e granular muito pequena, pouco desenvolvida, ocorrendo em alguns domínios mais porosos. $\mathrm{O}$ plasma é amarelado, com estrutura plásmica isotrópica a argilassépica. $\mathrm{O}$ esqueleto é composto por quartzo, com micas intemperizadas comuns, amareladas e brilhantes. Feldspatos cinzento-claros, em diversos estágios de decomposição. A distribuição relativa é porfirogrânica a intertéxtica. Os vazios são formados por poros tubulares e cavidades entre os microagregados. As feições pedológicas são pedotúbulos compostos por material microagregado. Concreção ferruginosa arredondada, com $0,6 \mathrm{~mm}$ de diâmetro. A porção central é porosa e vermelha, com alguns grãos de quartzo. Esta porção é circundada por faixas alternadas, vermelho-amarelas e vermelho-brunadas, com pontuações mais escurecidas e brilhantes formadas por hematita coesa. Nódulos ferruginosos pouco abundantes, pouco a mediamente impregnados, parcialmente decompostos

- Horizonte C, 200-210 cm: material avermelhado com domínios milimétricos irregulares mais amarelados. Minerais primários intemperizáveis são comuns. A estrutura é maciça e apresenta domínios mais porosos com agregados granulares muito pequenos, moderadamente desenvolvidos. $\mathrm{O}$ plasma é argiloso com estrutura plásmica silassépica e latissépica. O esqueleto é composto por quartzo, feldspatos e micas em decomposição comuns. Os microagregados apresentavam maior quantidade de areia fina e muito fina em relação ao fundo matricial adjacente. A distribuição relativa é porfirogrânica. Os vazios são do tipo cavidades e poros intergranulares formados pelo empilhamento de microagregados. As feições pedológicas são pedotúbulos, pápulas e nódulos. Os pedotúbulos têm formato cilindrico, com 1,5 a $4 \mathrm{~mm}$ de diâmetro. São do tipo agrotubos, mediamente nítidos. As pápulas são amareladas, formadas por pseudomorfos de feldspatos, com tamanho inferior a $2 \mathrm{~mm}$. Alguns cristais alongados são identificados na matriz argilosa das pápulas. Possivelmente formados por gibbsita, acinzentada e com tamanho inferior a $100 \mu \mathrm{m}$. Os nódulos são de natureza ferruginosa, com formato irregular e tamanho inferior a $3 \mathrm{~mm}$. Os contornos são irregulares, com aspecto interno heterogêneo, pouco impregnados com material ferruginoso, o qual apresenta-se substituído por um plasma amarelado.

\subsection{Meia encosta - C2: LATOSSOLO AMARELO}

- Horizonte $\mathrm{Bw}, 50-60 \mathrm{~cm}$ : material com aspecto e microestrutura semelhantes ao horizonte $\mathrm{Bw}$ do perfil do topo $(\mathrm{C} 1)$. Algumas diferenças em relação a esta amostra são destacadas. $\mathrm{O}$ plasma denota anisotropia mais evidente com estrutura plásmica insépica a massépica. As feições pedológicas são pedotúbulos e micronódulos ferruginosos e gibbsíticos. Os pedotúbulos são do tipo agrotubos, cilíndricos, com 1 a $3 \mathrm{~mm}$ de diâmetro. São fracamente a mediamente aderentes, preenchidos por material microagregado mais poroso. Os nódulos ferruginosos têm tamanho inferior a $4 \mathrm{~mm}$ de 
diâmetro, com ocorrência rara $(<1 \%)$, mediamente a fracamente impregnados. Internamente apresentavam concentrações de biotita ferruginizada. Os nódulos gibbsíticos são inferiores a $300 \mu \mathrm{m}$, com formato subangular, limites moderadamente nítidos. Cristais acinzentados claros com formato irregular podem ser identificados, com tamanho inferior a $10 \mu \mathrm{m}$.

- Horizonte BC, 140-150 cm: material amarelo-avermelhado com maior quantidade de minerais primários intemperizáveis. A estrutura plásmica é latissépica. Os feldspatos e micas são ocasionais $(<5 \%)$. A estrutura e as feições pedológicas são semelhantes ao observado na amostra anterior.

- Horizonte C, 170-180 cm: material avermelhado heterogêneo, com domínios irregulares amarelados. Estes domínios ocorrem espalhados na matriz e circundando alguns grãos de cascalho e nódulos ferruginosos. A amostra apresenta uma litorrelíquia centimétrica. A estrutura é maciça, com domínios formados por agregados granulares muito pequenos, mediamente desenvolvidos. $\mathrm{O}$ plasma é argiloso com estrutura plásmica massépica. $\mathrm{O}$ esqueleto é formado por grãos de quartzo, com cascalho e feldspatos e micas com ocorrência ocasional a freqüente $(5$ a $10 \%)$. A distribuição relativa é porfirogrânica e intertéxtica. Os vazios são representados por cavidades e poros de amontoamento de microagregados. As feições pedológicas são semelhantes a amostra do horizonte $\mathrm{Bw}$, com algumas variações. Os nódulos são mais abundantes e mediamente a fracamente impregnados por material ferruginoso. Os nódulos de gibbsita ocorriam na matriz e no interior da litorrelíquia.

\section{Solos da borda da colina}

\subsection{Perfil - TR2/I: LATOSSOLO AMARELO}

- Horizonte BA, 5-15 cm: material bruno-amarelado, com raízes finas abundantes e alguns fragmentos vegetais. A estrutura é composta, com agregados grumosos de 1 a 4 $\mathrm{mm}$ de diâmetro, moderadamente desenvolvidos. Há domínios com agregados granulares muito pequenos, com coloração ligeiramente mais escura, enriquecidos em matéria orgânica e argila. Em algumas porções, os grumos encontram-se desagregados, com aspecto mais arenoso. O plasma é organomineral com estrutura plásmica assépica a massépica. $\mathrm{O}$ esqueleto é composto por grãos de quartzo com predomínio de areia fina. Os feldspatos são raros $(<1 \%)$. Os vazios são do tipo cavidades entre agregados, muito abundantes. A distribuição relativa é intertéxtica a aglomeroplásmica. As feições pedológicas são pedotúbulos e nódulos ferruginosos. Os pedotúbulos são do tipo agrotubos com formato cilíndrico, com $2 \mathrm{~mm}$ de diâmetro, mediamente nítidos. Os nódulos ferruginosos são raros, com tamanho inferior a $1 \mathrm{~mm}$ e fracamente impregnados. - Horizonte Bwl, 47-57 cm: material amarelado, com domínios mais porosos e raízes finas comuns. A estrutura é maciça a granular muito pequena, pouco desenvolvida e ocorre juntamente com material mais arenoso, ocupando as porções mais porosas. $\mathrm{O}$ plasma é argiloso com estrutura plásmica assépica e pontuações massépicas pouco abundantes. O esqueleto apresenta predomínio de grãos de quartzo, com granulometria heterogênea. Os minerais primários intemperizáveis são raros, com alguns feldspatos e 
micas raras. A distribuição relativa é intertéxtica. Os vazios são do tipo cavidades, com algumas vesículas em torno das raízes. As feições pedológicas são constituídas por pedotúbulos, pápulas e nódulos ferruginosos. Os pedotúbulos são do tipo agrotubos e granotubos, com formato cilíndrico e 2 a $3 \mathrm{~mm}$ de diâmetro. As pápulas são amareladas, arredondadas, com diâmetro inferior a $0,5 \mathrm{~mm}$. Os nódulos ferruginosos são raros, inferiores a $1 \mathrm{~mm}$ de diâmetro. As bordas são mediamente angulosas, com superficie rugosa. O grau de impregnação é médio, podendo-se identificar grãos de quartzo internamente.

- Horizonte Bw2, 85-95 cm: fundo matricial amarelado, com mosqueados amareloavermelhados, comuns em torno dos canais de raízes; domínios acinzentados difusos, mais porosos e com maior quantidade de areia média. A estrutura é maciça e em grãos simples nos domínios mais porosos. O plasma é argiloso e a estrutura plásmica é do tipo assépica a isotrópica. Algumas pontuações com minerais pseudomorfos apresentam separações plásmicas mais nítidas do tipo insépica. $O$ esqueleto é semelhante ao da amostra anterior. A distribuição relativa é intertéxtica. Os vazios são constituídos por canais radiculares e cavidades. Nas porções arenosas, os vazios são de amontoamento.

- Horizonte BCg, 110-120 cm: material amarelo-acinzentado com mosqueados amareloavermelhados abundantes. A estrutura é maciça com poucos agregados granulares pequenos, restritos ao interior de pedotúbulos. Alguns microdomínios apresentam material arenoso desprovido de plasma. O plasma é argiloso, com concentração de óxidos de ferro nos mosqueados. A estrutura plásmica é assépica a insépica. $O$ esqueleto é composto por quartzo, com maior quantidade de cascalho e minerais primários intemperizáveis em relação ao horizonte anterior. O material no interior do pedotúbulo apresenta predomínio de areia fina e média, com ausência de cascalho. A distribuição relativa é intertéxtica no fundo matricial e aglomeroplásmica no pedotúbulo. Os vazios são do tipo cavidades e canais de raízes. As feições pedológicas são mosqueados, pedotúbulos e pápulas. Os mosqueados são comuns e nítidos, ocorrendo principalmente em torno de canais de raízes, numa faixa de 1 a $2 \mathrm{~mm}$ de espessura. Os pedotúbulos são granotubos com alguns agregados mais argilosos, com 1,4 a $1,5 \mathrm{~cm}$ de diâmetro. As paredes são enriquecidas em óxidos de ferro em algumas porções. As pápulas são amareladas, com até $1 \mathrm{~mm}$ de diâmetro, formadas por pseudomorfos de feldspatos.

- Horizonte $\mathrm{CBg}$, 130-140 cm: material acinzentado, com maior quantidade de minerais primários intemperizáveis e cascalho. A porção inferior da amostra apresenta litorrelíquias de granito alterado, menores que $2 \mathrm{~cm}$ de diâmetro. Os mosqueados são menores e menos abundantes em relação a amostra anterior. A estrutura é maciça com alguns agregados granulares pequenos $(0,5 \mathrm{a} 1 \mathrm{~mm})$. O plasma é argiloso, com algumas concentrações de ferro em mosqueados. A estrutura plásmica é massépica. $O$ esqueleto é formado por grãos de quartzo, com feldspatos e micas ocasionais (5\%). A distribuição relativa é aglomeroplásmica, com menor quantidade de plasma em relação a amostra anterior. Os vazios são representados por cavidades e canais de raízes. As feições pedológicas são mosqueados, pedotúbulos, pápulas, nódulos e concreções ferruginosas. Os mosqueados são formados pelo acúmulo de óxidos de ferro na periferia de canais de raizes. A quantidade, o tamanho e a impregnação por ferro são menores em relação ao 
horizonte $\mathrm{BCg}$. Os pedotúbulos são do tipo estriotubos, com $2 \mathrm{~mm}$ de diâmetro, apresentando porções com orientação dos grãos em faixas. As pápulas são amareladas, com tamanho inferior a $0,5 \mathrm{~mm}$ e arredondadas. O plásma é isotrópico. Os nódulos ferruginosos são pequenos, mediamente a fracamente impregnados, com contornos irregulares evidenciando acentuada dissolução. As concreções ferruginosas ocorrem na base do horizonte. As camadas externas são bruno-amareladas endurecidas e o interior é vermelho-amarelo e poroso.

\subsection{Perfil - TR3/I: GLEISSOLO HÁPLICO}

- Horizonte $\mathrm{Bi}, 45-55 \mathrm{~cm}$ : material amarelado relativamente homogêneo, com alguns domínios ligeiramente escurecidos e porosos. A estrutura é maciça com alguns agregados granulares pouco desenvolvidos, com até $2 \mathrm{~mm}$ de diâmetro. $\mathrm{O}$ plasma é argiloso com estrutura plásmica insépica. $O$ esqueleto é composto por grãos de quartzo, com feldspatos e micas raros $(<2 \%)$. A distribuição relativa é porfirogrânica. Os vazios são formados por cavidades e algumas fissuras pouco desenvolvidas. As feições pedológicas são pedotúbulos e nódulos ferruginosos e gibbsíticos. Os pedotúbulos são do tipo agrotubos, com 2 a $4 \mathrm{~mm}$ de diâmetro, pouco desenvolvidos e mais porosos que a matriz. Os nódulos ferruginosos são milimétricos $(<3 \mathrm{~mm})$, raros $(<1 \%)$, fracamente impregnados. Os nódulos gibbsíticos são pequenos $(<4 \mathrm{~mm})$, mediamente impregnados e podem estar parcialmente ferruginizados. Os cristais de gibbsita são acinzentados e apresentam aspecto granular, pouco nítido.

- Horizonte $\mathrm{CBg}$.90-100 cm: material amarelo-acinzentado, com maior quantidade de nódulos gibbsíticos e minerais primários intemperizáveis. A estrutura é maciça, com domínios enriquecidos em plasma, com fissuras delimitando agregados poliédricos subangulares, pequenos $(<1 \mathrm{~mm})$, fracamente desenvolvidos. O plasma é argiloso, com estrutura plásmica massépica. $\mathrm{O}$ esqueleto é constituído por grãos de quartzo, com cascalho. Os feldspatos são raros $(<2 \%)$ e as micas são ocasionais a freqüentes $(5$ a $10 \%$ ). A distribuição relativa é intertéxtica a porfirogrânica. Os vazios são representados por cavidades e fissuras. As feições pedológicas são nódulos gibbsíticos e ferruginosos. Os nódulos gibbsíticos são ocasionais (5\%), com até $12 \mathrm{~mm}$ de diâmetro. $\mathrm{O}$ aspecto é semelhante aos nódulos presentes no horizonte $\mathrm{Bi}$. Os nódulos ferruginosos são raros (< $1 \%$ ), parcialmente impregnados, com 4 a $6 \mathrm{~mm}$ de diâmetro. Apresentam internamente cristais de biotita ferruginizados.

\section{Solos da planície hidromórfica}

\subsection{Perfil com horizonte Bh endurecido - P1: ESPODOSSOLO CÁRBICO}

- Coprólito, 5-0 cm: material organomineral com diferentes níveis de enriquecimento em matéria orgânica. As raízes são finas e comuns. A estrutura é composta, com predomínio de agregados granulares grandes, com 0,6 a $1 \mathrm{~cm}$ de diâmetro e porções com aspecto maciço. Os agregados são bruno-escuros a bruno-acinzentados, com distribuição heterogênea da matéria orgânica. Há domínios isolados com areia branca. O plasma é organomineral, com estrutura plásmica isotrópica. $\mathrm{O}$ esqueleto é formado por grãos de 
quartzo, com predomínio de areia fina. Os feldspatos são raros $(<1 \%)$. A distribuição relativa é aglomeroplásmica e granular em domínios mais arenosos. O material orgânico é composto por fragmentos vegetais finos $(<1 \mathrm{~mm})$, em diferentes estágios de decomposição. Alguns destes fragmentos conservam a estrutura vegetal. Os vazios são muito abundantes, constituídos por canais e cavidades. O canal de circulação da minhoca é arredondado, com 0,9 a $1 \mathrm{~cm}$ de diâmetro. As paredes têm revestimento parcial com matéria orgânica.

- Horizonte A 0-10 cm: material organomineral, bruno-escuro, semelhante ao coprólito, com distribuição heterogênea da matéria orgânica. A estrutura é formada por agregados granulares, com 0,7 a $1,5 \mathrm{~cm}$ de diâmetro, moderadamente desenvolvidos. O plasma é organomineral, com estrutura plásmica isotrópica. O esqueleto é composto por quartzo, com predomínio de areia fina; alguns feldspatos raros. A distribuição relativa é aglomeroplásmica. O material orgânico tem aspecto semelhante ao presente nos coprólitos. Os vazios são muito abundantes, constituídos por cavidades e alguns canais.

- Horizonte Bh, 70-80 cm: material bruno-acinzentado escuro, com domínios milimétricos (5 a $10 \mathrm{~mm}$ ) mais escuros e com formato arredondado. Apresenta pontuações com areia branca fina e porções mais arenosas e claras. A estrutura é maciça, com agregados angulosos pequenos $(<0,5 \mathrm{~mm})$ formados pelo fraturamento dos domínios enriquecidos em matéria orgânica. Os volumes mais claros têm estrutura granular. O plasma é organomineral com concentração em canais de raízes e pedotúbulos, com 2 a $4 \mathrm{~mm}$ de diâmetro. $O$ plasma escuro e endurecido acumula-se também na porção superior de litorrelíquias centimétricas. Nesta porção o material fino preenche as fissuras dos minerais primários parcialmente decompostos. A estrutura plásmica é isotrópica. $\mathrm{O}$ esqueleto é constituído por grãos de quartzo e superficie intensamente corroída. Os minerais primários decomponíveis estão presentes somente nas litorrelíquias. O grau de decomposição destes minerais é variável, com intemperismo concentrando-se nos planos de clivagem. Nas bordas das litorrelíquias os feldspatos e micas estão quase completamente decompostos. A distribuição relativa é aglomeroplásmica a granular. $\mathrm{O}$ material orgânico é representado por raízes finas e médias, com 0,5 a $4 \mathrm{~mm}$ de diâmetro, parcialmente decompostas. Boa parte do material orgânico é muito escuro e acumula-se em canais de raízes e pedotúbulos. Apresenta-se microfissurado e muitas vezes associado a domínios com maior quantidade de areia grossa. Os vazios são formados por canais de raízes e cavidades; pouco abundantes. A amostra apresenta pedotúbulos do tipo granotubos e agrotubos. Os granotubos têm de 1 a $1,5 \mathrm{~cm}$ de diâmetro e são constituídos principalmente por areia fina; mais claros que o fundo matricial adjacente. Os agrotubos têm cerca de $2 \mathrm{~mm}$ de diâmetro e contêm agregados arredondados mais escuros e enriquecidos em matéria orgânica. Em algumas porções são associados com domínios com maior quantidade de areia grossa.

- Horizonte Bh, 100-110 cm: semelhante a amostra anterior, com maior quantidade de areia grossa e cascalho.

- Horizonte BhC, 110-120 cm: material bruno-acinzentado, com domínios arredondados, mais escuros, formados pelo acúmulo de matéria orgânica em pedotúbulos e canais radiculares; domínios milimétricos difusos, mais claros e com areia branca. Algumas 
porções bruno-amareladas e bruno-avermelhadas são compostas por feldspatos e micas intemperizados. A estrutura é maciça com alguns agregados angulosos fracamente desenvolvidos nos domínios enriquecidos em matéria orgânica. $\mathrm{O}$ plasma é organomineral, com estrutura plásmica isotrópica no material bruno-escuro e brunoavermelhado e massépica nos pseudomorfos bruno-amarelados. $O$ esqueleto é constituído por quartzo e feldspatos e micas alterados são ocasionais $(5 \%)$, associados principalmente a pedotúbulos preenchidos com material bruno-avermelhado. A distribuição relativa é aglomeroplásmica na matriz e porfirogrânica no pedotúbulo. Os vazios são representados cavidades, pouco abundantes. O material orgânico concentra-se em canais de raízes e em pedotúbulos, revestindo parcialmente os grãos e preenchendo poros, formando uma massa fina, microfissurada. As feições pedológicas são pápulas e pedotúbulos. As pápulas são bruno-amareladas, formadas por pseudomorfos de feldspatos. Têm tamanho inferior a $5 \mathrm{~mm}$, são arredondadas e concentram-se principalmente nos pedotúbulos. Estas estruturas são do tipo isotubos e estriotubos, com 2 a $4 \mathrm{~mm}$ de diâmetro. Os isotubos apresentam concentração de matéria orgânica e minerais primários decompostos, são bruno-avermelhados. Os estriotubos mostram enriquecimento em areia, com grãos das frações mais grosseiras alinhados longitudinalmente em algumas porções do pedotúbulo.

- Horizonte Cgr, 130-140 cm: material bruno-acinzentado manchado, com presença freqüente de minerais pseudomorfos bruno-amarelados. Os volumes bruno-avermelhadoescuros enriquecidos em matéria orgânica ocorrem em canais de raízes e pedotúbulos. A estrutura é herdada da rocha, com aparecimento de agregados poliédricos, com 0,1 a 0,8 $\mathrm{mm}$ de diâmetro, pouco desenvolvidos, delimitados por microfissuras nos pseudomorfos e nos pedotúbulos. O plasma é organomineral, com estrutura plásmica isotrópica no material bruno-avermelhado. Nos pseudomorfos, o plasma é mineral, com estrutura massépica. O esqueleto é constituído de quartzo, com granulometria grosseira. Os feldspatos e micas intemperizados são abundantes. A distribuição relativa é porfirogrânica. O material orgânico concentrava-se nos pedotúbulos e canais de raizes. Os vazios são pouco abundantes, formados por cavidades, canais radiculares e fissuras. As feições pedológicas são pápulas e pedotúbulos. As pápulas são semelhantes as encontradas no horizonte $\mathrm{BCh}$. Os pedotúbulos são do tipo isotubos, brunoavermelhados, com 2 a $3 \mathrm{~mm}$ de diâmetro. O material interno é organomineral, com poucos minerais primários decompostos.

\subsection{Perfil com Bh solto - P3: ESPODOSSOLO CÁRBICO}

- Horizonte E/Bh, 140-145 cm: Material heterogêneo, com matriz bruno-escura, com dominios bruno-acinzentados, milimétricos, arredondados, com pouco plasma. Estes domínios perfazem 20 a $30 \%$ da amostra. Há porções bruno-avermelhado-escuras, milimétricas a centimétricas, cilindricas, enriquecidas em matéria orgânica e com predomínio de areia grossa. A estrutura é maciça, com agregados poliédricos delimitados por fissuras, pouco desenvolvidos nas porções bruno-avermelhadas. Nos domínios brunoacinzentados a estrutura é granular. O plasma é organomineral com estrutura plásmica isotrópica a insépica. $\mathrm{O}$ esqueleto é predominantemente composto por quartzo. Os 
feldspatos são raros $(<1 \%)$ e as micas são ausentes. A distribuição relativa é aglomeroplásmica e intertéxtica, com variações, porfirogrânica, nas porções enriquecidas em matéria orgânica e granular nos bolsões mais arenosos. O material orgânico concentra-se em pedotúbulos e canais radiculares. As raízes são médias a grossas ( 2 a 5 $\mathrm{mm}$ ), parcialmente a quase completamente decompostas. Os vazios são representados por cavidades, fissuras e vazios de amontoamento. As feições pedológicas são pápulas e pedotúbulos. As pápulas são raras $(<1 \%)$, bruno-amareladas, pequenas, com diâmetro inferior a $0,5 \mathrm{~mm}$; constituídas de pseudomorfos. Os pedotúbulos são do tipo granotubos e isotubos. Os granotubos são bruno-acinzentados, com 3 a $8 \mathrm{~mm}$ de diâmetro, compostos por areia fina. Os isotubos são bruno-avermelhado-escuros, cilíndricos, com 4 a $12 \mathrm{~mm}$ de diâmetro, orientados verticalmente; enriquecidos em matéria orgânica, com predomínio de areia grossa.

- Horizonte $\mathrm{Cg}, 150-155 \mathrm{~cm}$ : Material bruno-acinzentado-claro, com domínios brunoavermelhados, arredondados, enriquecidos em matéria orgânica. A estrutura é maciça com agregados poliédricos pequenos $(<1 \mathrm{~mm})$, fracamente desenvolvidos. $\mathrm{O}$ plasma é mineral, com concentração de matéria orgânica em pedotúbulos. A matriz possui estrutura plásmica insépica e o material presente nos pedotúbulos e pápulas tem estrutura plásmica massépica a latissépica. O esqueleto mostra predomínio de quartzo. Os feldspatos e micas são raros (2\%). A distribuição relativa é intertéxtica na matriz e porfirogrânica nos pedotúbulos. O material orgânico é menos abundante que na amostra anterior, ocorrendo principalmente em pedotúbulos. Os vazios são constituídos por cavidades e algumas fissuras. As feições pedológicas são pápulas e pedotúbulos. As pápulas são bruno-claro-acinzentadas, arredondadas, ocasionais (5\%), menores que 1 $\mathrm{mm}$ de diâmetro. Os pedotúbulos são isotubos, com material organomineral brunoavermelhado a bruno-escuro; de 6 a $8 \mathrm{~mm}$ de diâmetro, compostos principalmente por areia fina e algumas porções com maior ocorrência de areia grossa. 


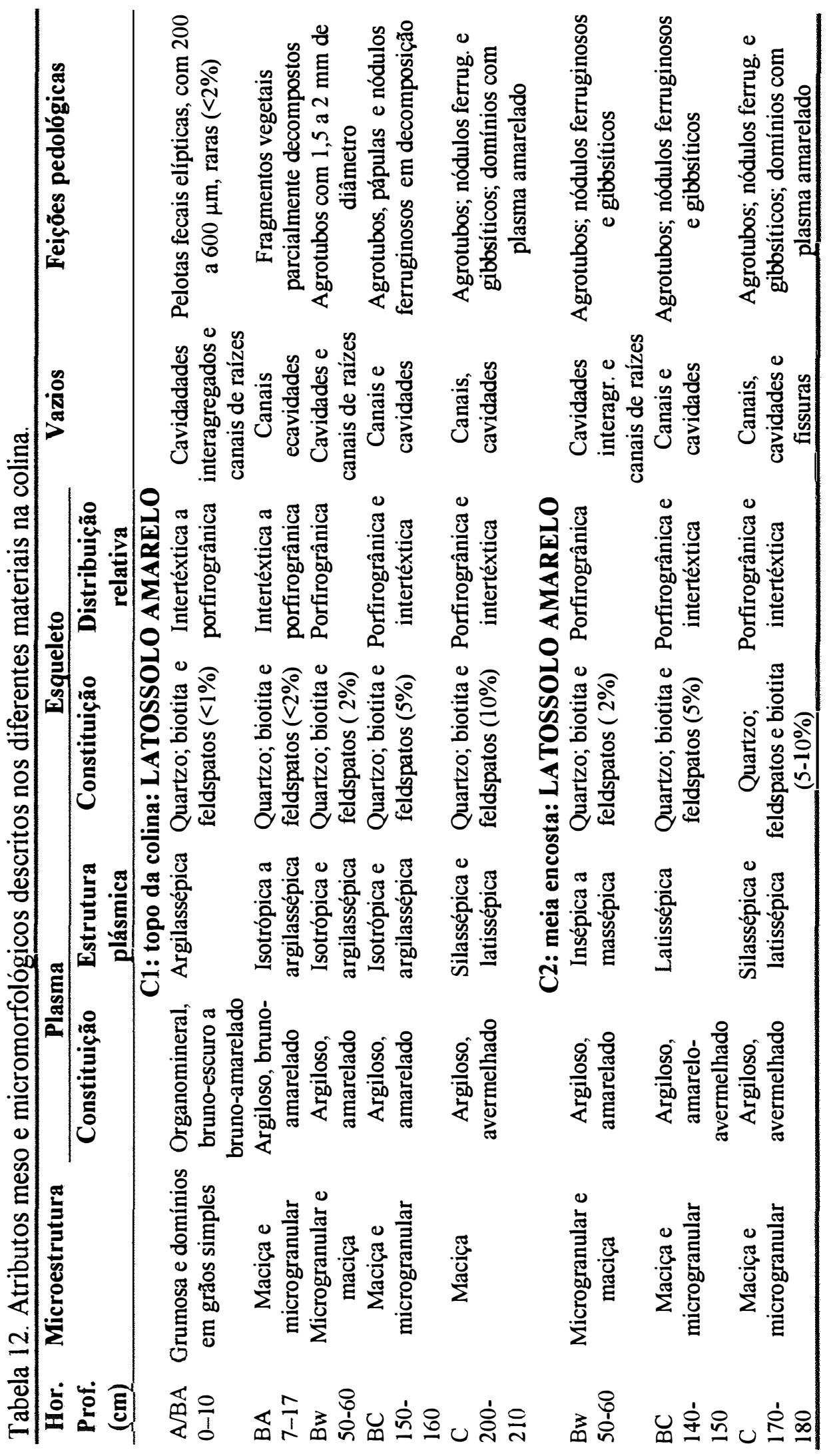




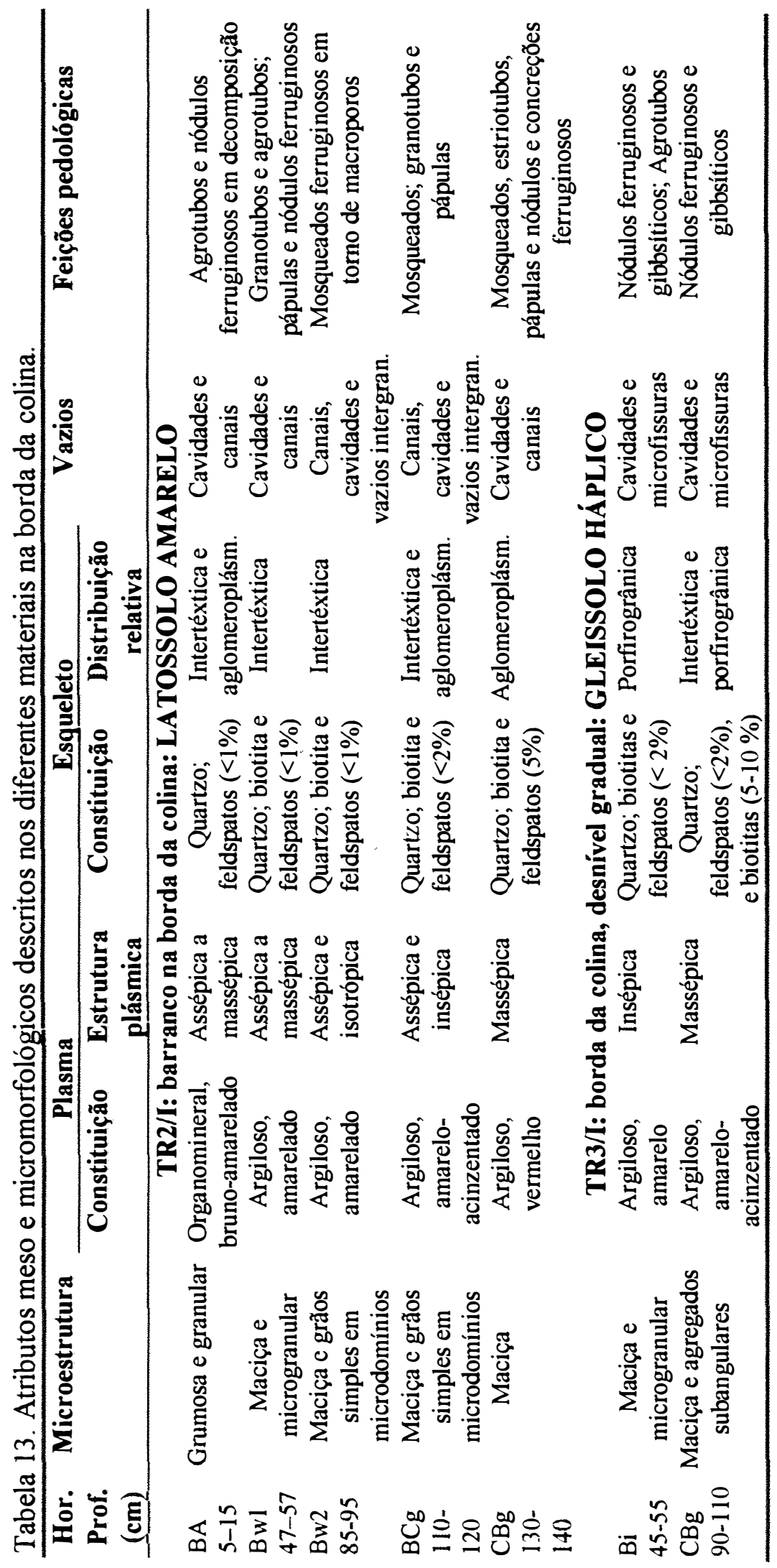




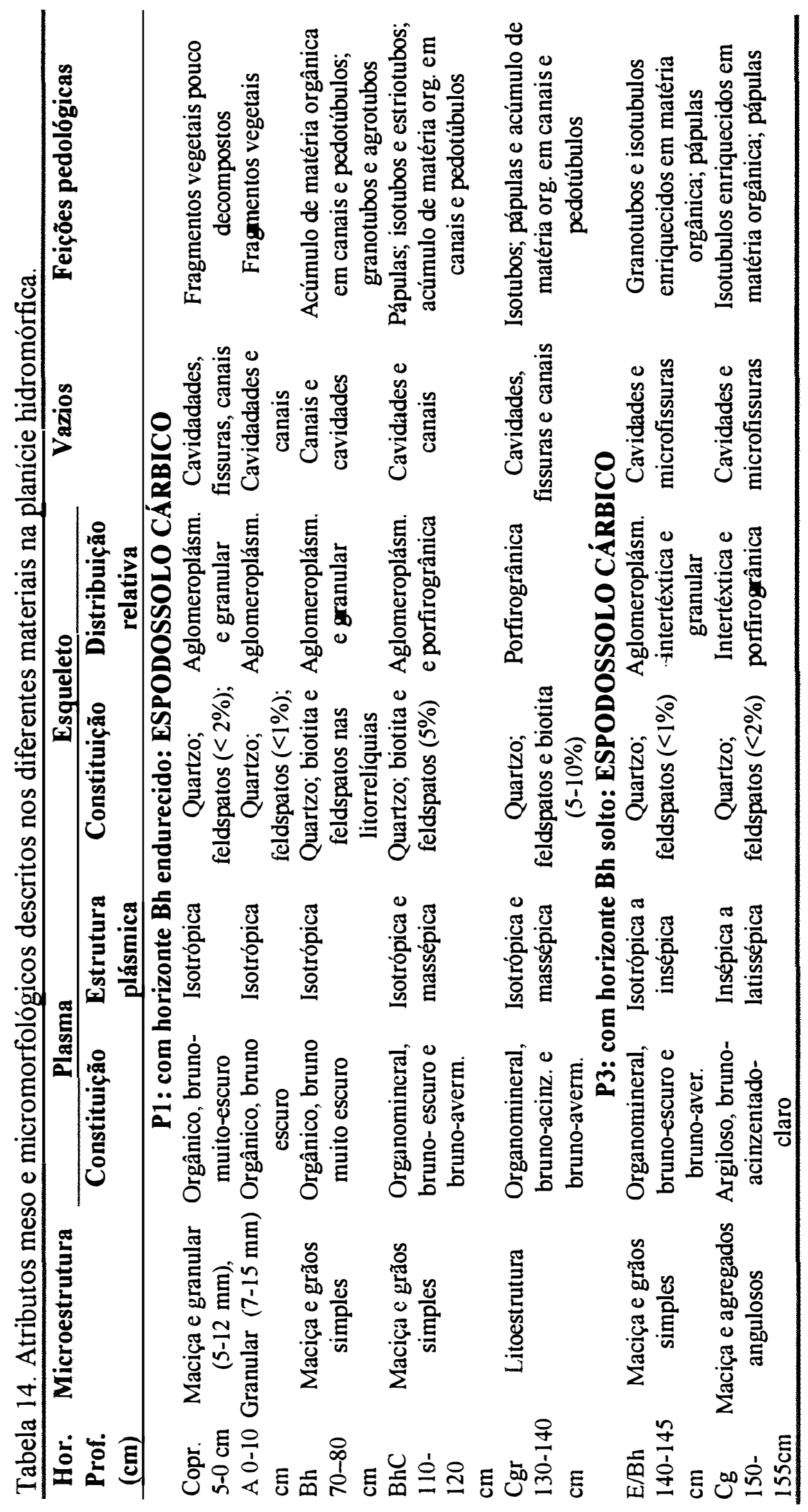




\section{ANEXO C}

Atributos físicos do solo: densidade e granulometria 
Tabela 15. Densidade e granulometria do solo nos perfis da porção superior da colina.

\begin{tabular}{|c|c|c|c|c|c|c|c|}
\hline \multirow[t]{2}{*}{ Horiz. } & \multirow[t]{2}{*}{ Profun. } & \multirow[t]{2}{*}{$\begin{array}{l}\text { Densidade } \\
\text { do solo }^{(1)}\end{array}$} & \multirow[t]{2}{*}{ Cascalho } & \multicolumn{3}{|c|}{$\begin{array}{l}\text { Frações granulométricas na terra } \\
\text { fina }(<2 \mathrm{~mm})\end{array}$} & \multirow{2}{*}{$\begin{array}{l}\text { Relação } \\
\text { silte/argila }\end{array}$} \\
\hline & & & & Areia & Silte & $\overline{\text { Argila }}$ & \\
\hline & $\mathrm{cm}$ & $\mathrm{g} \mathrm{cm}^{-3}$ & $\mathrm{~g} \mathrm{~kg}^{-1}$ & & $\mathrm{~g} \mathrm{~kg}^{-1}$ & & \\
\hline \multicolumn{8}{|c|}{ C1: topo da colina } \\
\hline A & $0-2$ & - & 2 & 580 & 230 & 190 & 1,21 \\
\hline BA & $10-20$ & 1,19 & 16 & 540 & 190 & 270 & 0,70 \\
\hline $\mathrm{Bw}$ & $50-70$ & 1,17 & 16 & 480 & 170 & 350 & 0,49 \\
\hline $\mathrm{BC}$ & $140-160$ & 1,24 & 95 & 500 & 140 & 360 & 0,39 \\
\hline $\mathrm{C}$ & $200-220$ & 1,27 & 64 & 530 & 220 & 250 & 0,88 \\
\hline \multicolumn{8}{|c|}{ C2: meia encosta } \\
\hline A & $0-10$ & -. & 9 & 650 & 170 & 180 & 0,94 \\
\hline BA & $10-20$ & 1,21 & 70 & 650 & 150 & 200 & 0,75 \\
\hline \multirow[t]{4}{*}{$\mathrm{Bw}$} & $20-30$ & 1,25 & 28 & 540 & 160 & 300 & 0,53 \\
\hline & $50-60$ & 1,34 & 40 & 530 & 160 & 310 & 0,52 \\
\hline & $80-100$ & - & 41 & 490 & 170 & 340 & 0,50 \\
\hline & $100-120$ & 1,25 & 95 & 540 & 160 & 300 & 0,53 \\
\hline $\mathrm{BC}$ & $140-160$ & 1,33 & 142 & 590 & 140 & 270 & 0,52 \\
\hline $\mathrm{C}$ & $180-200$ & - & 69 & 570 & 210 & 220 & 0,95 \\
\hline
\end{tabular}

1. Média de três repetições; $(---)=$ Não analisado

Tabela 16. Distribuição granulométrica e análise estatística da fração areia dos solos na parte superior da colina.

\begin{tabular}{|c|c|c|c|c|c|c|c|c|c|}
\hline \multirow[t]{2}{*}{ Horiz. } & \multirow[t]{2}{*}{ Profun. } & \multicolumn{5}{|c|}{ Frações de areia $^{(1)}$} & \multirow{2}{*}{$\begin{array}{c}\text { Relação } \\
\text { Areia } \\
\text { fina/Total }\end{array}$} & \multirow{2}{*}{$\begin{array}{l}\text { Diâmetro } \\
\text { médio }\end{array}$} & \multirow{2}{*}{$\begin{array}{l}\text { Amplitude } \\
D m \pm D p^{(2)}\end{array}$} \\
\hline & & $\begin{array}{r}\text { Muito } \\
\text { Grossa }\end{array}$ & Grossa & Média & Fina & $\begin{array}{c}\text { Muito } \\
\text { Fina } \\
\end{array}$ & & & \\
\hline & $\mathrm{cm}$ & \multicolumn{5}{|c|}{ 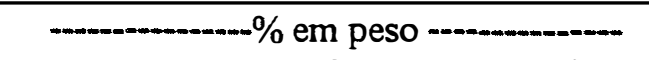 } & & $\mathrm{mm}$ & $\mathrm{mm}$ \\
\hline \multicolumn{10}{|c|}{ C1: topo da colina } \\
\hline A & $0-2$ & 3 & 14 & 19 & 47 & 17 & 0,47 & 0,25 & $0,13-0,50$ \\
\hline BA & $10-20$ & 6 & 22 & 20 & 33 & 19 & 0,33 & 0,27 & $0,12-0,61$ \\
\hline $\mathrm{Bw}$ & $50-70$ & 13 & 21 & 17 & 35 & 14 & 0,35 & 0,30 & $0,12-0,75$ \\
\hline $\mathrm{BC}$ & $140-160$ & 22 & 20 & 14 & 28 & 16 & 0,28 & 0,36 & $0,13-0,96$ \\
\hline $\mathrm{C}$ & $200-220$ & 21 & 25 & 17 & 26 & 11 & 0,26 & 0,41 & $0,16-1,03$ \\
\hline \multicolumn{10}{|c|}{ C2: meia encosta } \\
\hline A & $0-10$ & 6 & 22 & 22 & 34 & 17 & 0,34 & 0,27 & $0,12-0,62$ \\
\hline BA & $10-20$ & 17 & 28 & 22 & 22 & 11 & 0,22 & 0,40 & $0,16-0,99$ \\
\hline \multirow[t]{4}{*}{ Bw } & $20-30$ & 9 & 19 & 20 & 33 & 19 & 0,33 & 0,27 & $0,11-0,67$ \\
\hline & $50-60$ & 11 & 21 & 19 & 30 & 19 & 0,30 & 0,29 & $0,12-0,72$ \\
\hline & $80-100$ & 12 & 18 & 18 & 31 & 20 & 0,31 & 0,28 & $0,11-0,71$ \\
\hline & $100-120$ & 17 & 19 & 17 & 30 & 19 & 0,30 & 0,32 & $0,12-0,85$ \\
\hline BC & $140-160$ & 20 & 24 & 19 & 25 & 12 & 0,25 & 0,40 & $0,15-1,00$ \\
\hline C & $180-200$ & 21 & 26 & 19 & 25 & 9 & 0,25 & 0,43 & $0,18-1,04$ \\
\hline
\end{tabular}

1. Frações (mm): Muito grossa: 2-1; Grossa: 1-0,5; Média: 0,5-0,25; Fina: 0,25-0,1; Muito fina: $0,1-0,05 ; 2$. Diâmetro médio \pm desvio padrão. 
Tabela 17. Densidade e granulometria do solo nos perfis da porção inferior da colina e zona de contato com a planície.

\begin{tabular}{|c|c|c|c|c|c|c|c|}
\hline \multirow[t]{2}{*}{ Horiz. } & \multirow[t]{2}{*}{ Profun. } & \multirow[t]{2}{*}{$\begin{array}{c}\text { Densidade } \\
\text { do solo }\end{array}$} & \multirow[t]{2}{*}{ Cascalho } & \multicolumn{3}{|c|}{$\begin{array}{c}\text { Frações granulométricas na terra } \\
\text { fina }(<2 \mathrm{~mm})\end{array}$} & \multirow{2}{*}{$\begin{array}{c}\text { Relação } \\
\text { silte/argila }\end{array}$} \\
\hline & & & & Areia & Silte & Argila & \\
\hline \multicolumn{4}{|c|}{ TR2/I: borda da colina } & \multicolumn{3}{|c|}{ rda da colina } & \\
\hline A & $0-3$ & $-\cdots$ & 3 & 670 & 210 & 120 & -- \\
\hline BA & $10-20$ & 1,12 & 6 & 700 & 160 & 140 & 1,14 \\
\hline Bw1 & $50-60$ & 1,34 & 9 & 620 & 190 & 190 & 1,00 \\
\hline Bw2 & $85-95$ & 1,33 & 14 & 560 & 220 & 220 & 1,00 \\
\hline $\mathrm{BCg}$ & $110-120$ & 1,50 & 10 & 650 & 190 & 160 & 1,18 \\
\hline $\mathrm{CBg}$ & $125-135$ & 1,59 & 16 & 640 & 200 & 160 & 1,25 \\
\hline $\mathrm{Cg}$ & $140-150$ & 1,41 & 178 & 720 & 140 & 140 & 1,00 \\
\hline \multicolumn{8}{|c|}{ TR2/II: planície, $1 \mathrm{~m}$ da borda da colina } \\
\hline A & $0-20$ & $-\cdots$ & 50 & 730 & 150 & 120 & -- \\
\hline $\mathrm{Cg}$ & $50-60$ & - & 40 & 920 & 60 & 20 & -- \\
\hline \multicolumn{8}{|c|}{ TR2/III: planície, $2,3 \mathrm{~m}$ da borda da colina } \\
\hline A & $0-15$ & -- & 26 & 660 & 220 & 120 & -- \\
\hline $\mathrm{Cg}$ & $55-65$ & -- & 769 & 920 & 40 & 40 & -- \\
\hline \multicolumn{8}{|c|}{ TR2/IV: planície, $5 \mathrm{~m}$ da borda da colina } \\
\hline A & $0-20$ & $-\cdots$ & 16 & 730 & 190 & 80 & -- \\
\hline $\mathrm{Cg}$ & $50-60$ & -- & 54 & 940 & 20 & 40 & -- \\
\hline \multicolumn{8}{|c|}{ TR3/I: borda da colina } \\
\hline A & $0-10$ & -- & 25 & 590 & 200 & 210 & 0,95 \\
\hline BA & $10-20$ & 1,33 & 31 & 480 & 230 & 290 & 0,79 \\
\hline $\mathrm{Bi}$ & $40-60$ & 1,45 & 45 & 490 & 190 & 320 & 0,59 \\
\hline $\mathrm{BCg}$ & $60-80$ & -- & 387 & 530 & 180 & 290 & 0,62 \\
\hline $\mathrm{CBg}$ & $80-100$ & 1,49 & 370 & 670 & 130 & 200 & 0,65 \\
\hline & $100-120$ & --- & 309 & 700 & 160 & 140 & 1,14 \\
\hline $\mathrm{C}$ & $120-140$ & -- & 235 & 740 & 140 & 120 & 1,17 \\
\hline & $140-160$ & --- & 190 & 800 & 120 & 80 & 1,50 \\
\hline \multicolumn{8}{|c|}{ TR3/II: transição, 4 m da borda } \\
\hline A & $0-10$ & --- & 19 & 670 & 190 & 140 & 1,36 \\
\hline$A B$ & $10-20$ & $\ldots$ & 30 & 590 & 230 & 180 & 1,28 \\
\hline $\mathrm{Bw}$ & $40-60$ & -- & 109 & 620 & 200 & 180 & 1,11 \\
\hline $\mathrm{BCg}$ & $60-80$ & -- & 270 & 600 & 200 & 200 & 1,00 \\
\hline $\mathrm{CBg}$ & $80-100$ & $\cdots$ & 490 & 590 & 190 & 220 & 0,86 \\
\hline $\mathrm{Cg}$ & $100-120$ & - & 555 & 630 & 210 & 160 & 1,31 \\
\hline \multicolumn{8}{|c|}{ TR3/III: planície, $6 \mathrm{~m}$ da borda da colina } \\
\hline A & $0-10$ & -- & 2 & 630 & 250 & 120 & --- \\
\hline \multirow{3}{*}{$\mathrm{Cg}$} & $10-20$ & -- & 19 & 780 & 120 & 100 & $-\cdots$ \\
\hline & $40-50$ & $\cdots$ & 22 & 880 & 80 & 40 & $-\cdots$ \\
\hline & $60-70$ & $-\cdots$ & 36 & 860 & 100 & 40 & -- \\
\hline
\end{tabular}

1. Média de três repetições; $(---)=$ Não analisado 
Tabela 18. Distribuição granulométrica e análise estatística da fração areia dos solos na borda da colina e zona de contato com a planície.

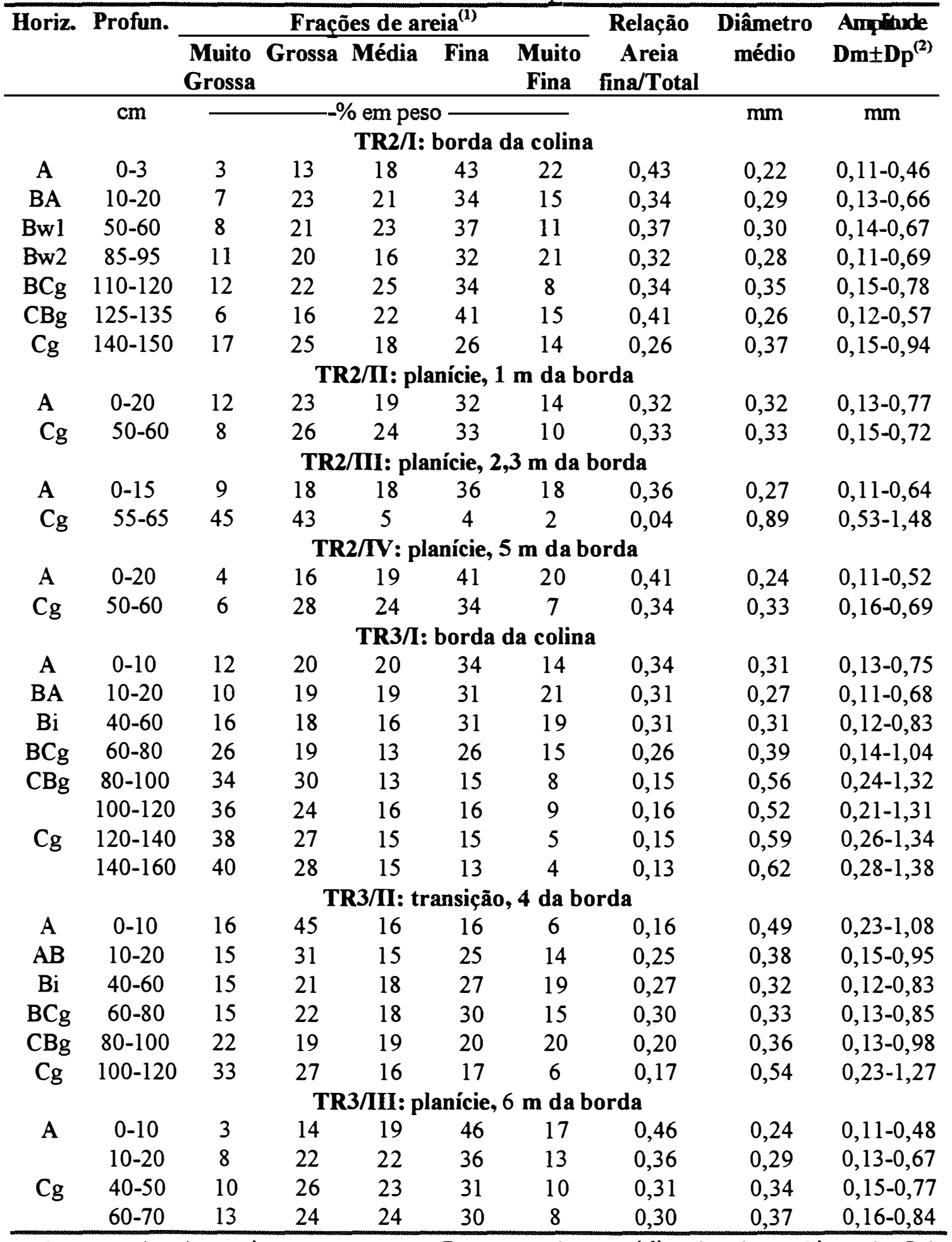

1. Frações (mm): Muito grossa: 2-1; Grossa: 1-0,5; Média: 0,5-0,25; Fina: 0,25-0,1; Muito fina: $0,1-0,05 ; 2$. Diâmetro médio \pm desvio padrão. 
Tabela 19. Densidade e granulometria do solo nos perfis da planície hidromórfica.

\begin{tabular}{|c|c|c|c|c|c|c|c|}
\hline \multirow[t]{2}{*}{ Horiz. } & \multirow[t]{2}{*}{ Profun. } & \multirow[t]{2}{*}{$\begin{array}{l}\text { Densidade } \\
\text { do solo }^{(1)}\end{array}$} & \multirow[t]{2}{*}{ Cascalho } & \multicolumn{3}{|c|}{$\begin{array}{c}\text { Frações granulométricas na terra } \\
\text { fina }(<2 \mathrm{~mm})\end{array}$} & \multirow{2}{*}{$\begin{array}{c}\text { Relação } \\
\text { silte/argila }\end{array}$} \\
\hline & & & & Areia & Silte & Argila & \\
\hline & $\mathrm{cm}$ & $\mathrm{g} \mathrm{cm}^{-3}$ & & & $\mathrm{~g} \mathrm{~kg}^{-1}$ & 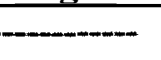 & \\
\hline \multicolumn{8}{|c|}{ P1: com Bh endurecido } \\
\hline Cop. & $15-0$ & 0,99 & 0 & 740 & 200 & 60 & --. \\
\hline A & $0-20$ & 0,73 & 0 & 750 & 210 & 40 & - \\
\hline $\mathrm{E}$ & $40-50$ & 1,66 & 4 & 940 & 40 & 20 & --- \\
\hline \multirow[t]{2}{*}{$\mathrm{Bh}$} & $75-85$ & 1,51 & 22 & 870 & 90 & 40 & -- \\
\hline & $90-100$ & --- & 43 & 860 & 80 & 60 & --- \\
\hline $\mathrm{BhC}$ & $110-120$ & 1,52 & 54 & 820 & 80 & 100 & --- \\
\hline $\mathrm{Cgr}$ & $140-150$ & 1,17 & 39 & 660 & 170 & 170 & 1,00 \\
\hline \multicolumn{8}{|c|}{ P3: com Bh solto } \\
\hline Cop. & $10-0$ & -- & 0 & 710 & 230 & 60 & -.. \\
\hline A & $0-10$ & $-\ldots$ & 0 & 730 & 210 & 60 & --- \\
\hline \multirow[t]{2}{*}{ E } & $30-40$ & -- & 0 & 840 & 120 & 40 & --- \\
\hline & $60-70$ & -. & 6 & 900 & 80 & 20 & $-\ldots$ \\
\hline $\mathrm{E} / \mathrm{Bh}$ & $120-130$ & $\ldots$ & 36 & 900 & 40 & 60 & --. \\
\hline $\mathrm{Cg}$ & $150-160$ & -- & 96 & 720 & 140 & 140 & 1,00 \\
\hline \multicolumn{8}{|c|}{ P5: com Bh solto } \\
\hline Cop. & $10-0$ & -- & 0 & 750 & 190 & 60 & - \\
\hline A & $0-10$ & -- & 1 & 820 & 120 & 60 & -- \\
\hline \multirow[t]{2}{*}{$\mathrm{E}$} & $30-40$ & $\ldots$ & 2 & 920 & 40 & 40 & -- \\
\hline & $100-110$ & -.. & 3 & 920 & 60 & 20 & -.- \\
\hline $\mathrm{E} / \mathrm{Bh}$ & $130-140$ & - & 8 & 900 & 60 & 40 & $-\ldots$ \\
\hline \multirow[t]{2}{*}{$\mathrm{Cg}$} & $150-160$ & $\ldots$ & 39 & 720 & 160 & 120 & --- \\
\hline & $170-180$ & -.. & 29 & 540 & 280 & 180 & 1,56 \\
\hline
\end{tabular}

1. Média de três repetições; $(---)$ = Não analisado 
Tabela 20. Distribuição granulométrica e análise estatística da fração areia dos solos na planície hidromórfica.

\begin{tabular}{|c|c|c|c|c|c|c|c|c|c|}
\hline \multirow[t]{2}{*}{ Horiz. } & \multirow[t]{2}{*}{ Profun. } & \multicolumn{5}{|c|}{ Frações de areia $^{(1)}$} & \multirow{2}{*}{$\begin{array}{c}\text { Relação } \\
\text { Areia } \\
\text { fina/Total }\end{array}$} & \multirow{2}{*}{$\begin{array}{l}\text { Diâmetro } \\
\text { médio }\end{array}$} & \multirow{2}{*}{$\begin{array}{l}\text { Amp rhude } \\
\operatorname{Dm} \pm D p^{(2)}\end{array}$} \\
\hline & & $\begin{array}{l}\text { Muito } \\
\text { Grossa }\end{array}$ & Grossa & Média & Fina & $\begin{array}{c}\text { Muito } \\
\text { Fina }\end{array}$ & & & \\
\hline & $\mathrm{cm}$ & \multicolumn{6}{|c|}{ - } & $\mathrm{mm}$ & $\mathrm{mm}$ \\
\hline \multicolumn{10}{|c|}{ P1: com Bh endurecido } \\
\hline Cop. & $15-0$ & 1 & 14 & 26 & 46 & 13 & 0,46 & 0,24 & $0,13-0,46$ \\
\hline A & $0-20$ & 1 & 17 & 28 & 40 & 14 & 0,40 & 0,25 & $0,13-0,49$ \\
\hline $\mathrm{E}$ & $40-50$ & 10 & 34 & 24 & 27 & 5 & 0,27 & 0,40 & $0,19-0,84$ \\
\hline \multirow[t]{2}{*}{$\mathrm{Bh}$} & $75-85$ & 18 & 26 & 21 & 28 & 7 & 0,28 & 0,42 & $0,18-0,97$ \\
\hline & $90-100$ & 21 & 23 & 20 & 28 & 8 & 0,28 & 0,42 & $0,17-1,01$ \\
\hline $\mathrm{BhC}$ & $110-120$ & 22 & 23 & 20 & 27 & 9 & 0,27 & 0,42 & $0,17-1,03$ \\
\hline $\mathrm{Cgr}$ & $140-150$ & 24 & 29 & 18 & 23 & 6 & 0,23 & 0,48 & $0,21-1,12$ \\
\hline \multicolumn{10}{|c|}{ P3: com Bh solto } \\
\hline Cop. & $10-0$ & 0 & 4 & 15 & 54 & 27 & 0,54 & 0,17 & $0,10-0,28$ \\
\hline A & $0-10$ & 0 & 7 & 16 & 51 & 26 & 0,51 & 0,18 & $0,10-0,32$ \\
\hline \multirow[t]{2}{*}{$\mathrm{E}$} & $30-40$ & 1 & 11 & 20 & 50 & 18 & 0,50 & 0,21 & $0,11-0,40$ \\
\hline & $60-70$ & 7 & 29 & 23 & 32 & 9 & 0,32 & 0,34 & $0,16-0,71$ \\
\hline $\mathrm{E} / \mathrm{Bh}$ & $120-130$ & 19 & 24 & 21 & 29 & 7 & 0,29 & 0,41 & $0,18-0,97$ \\
\hline $\mathrm{Cg}$ & $150-160$ & 17 & 19 & 19 & 33 & 12 & 0,33 & 0,36 & $0,14-0,88$ \\
\hline \multicolumn{10}{|c|}{ P5: com Bh solto } \\
\hline Cop. & $10-0$ & 0 & 8 & 21 & 48 & 23 & 0,48 & 0,19 & $0,11-0,37$ \\
\hline $\mathrm{A}$ & $0-10$ & 2 & 15 & 21 & 45 & 17 & 0,45 & 0,24 & $0,12-0,48$ \\
\hline \multirow[t]{2}{*}{ E } & $30-40$ & 2 & 16 & 27 & 43 & 11 & 0,43 & 0,26 & $0,13-0,50$ \\
\hline & $100-110$ & 2 & 16 & 26 & 43 & 12 & 0,43 & 0,26 & $0,13-0,50$ \\
\hline $\mathrm{E} / \mathrm{Bh}$ & $130-140$ & 4 & 23 & 21 & 39 & 12 & 0,39 & 0,28 & $0,13-0,58$ \\
\hline \multirow[t]{2}{*}{$\mathrm{Cg}$} & $150-160$ & 17 & 24 & 19 & 31 & 10 & 0,31 & 0,38 & $0,16-0,92$ \\
\hline & $170-180$ & 17 & 22 & 22 & 30 & 9 & 0,30 & 0,38 & $0,16-0,92$ \\
\hline
\end{tabular}

1. Frações (mm): Muito grossa: 2-1; Grossa: 1-0,5; Média: 0,5-0,25; Fina: 0,25-0,1;

Muito fina: $0,1-0,05 ; 2$. Diâmetro médio \pm desvio padrão 


\begin{abstract}
ANEXO D
Difratogramas de raio- $X$ :

Frações silte, óxidos concentrados e argila
\end{abstract}



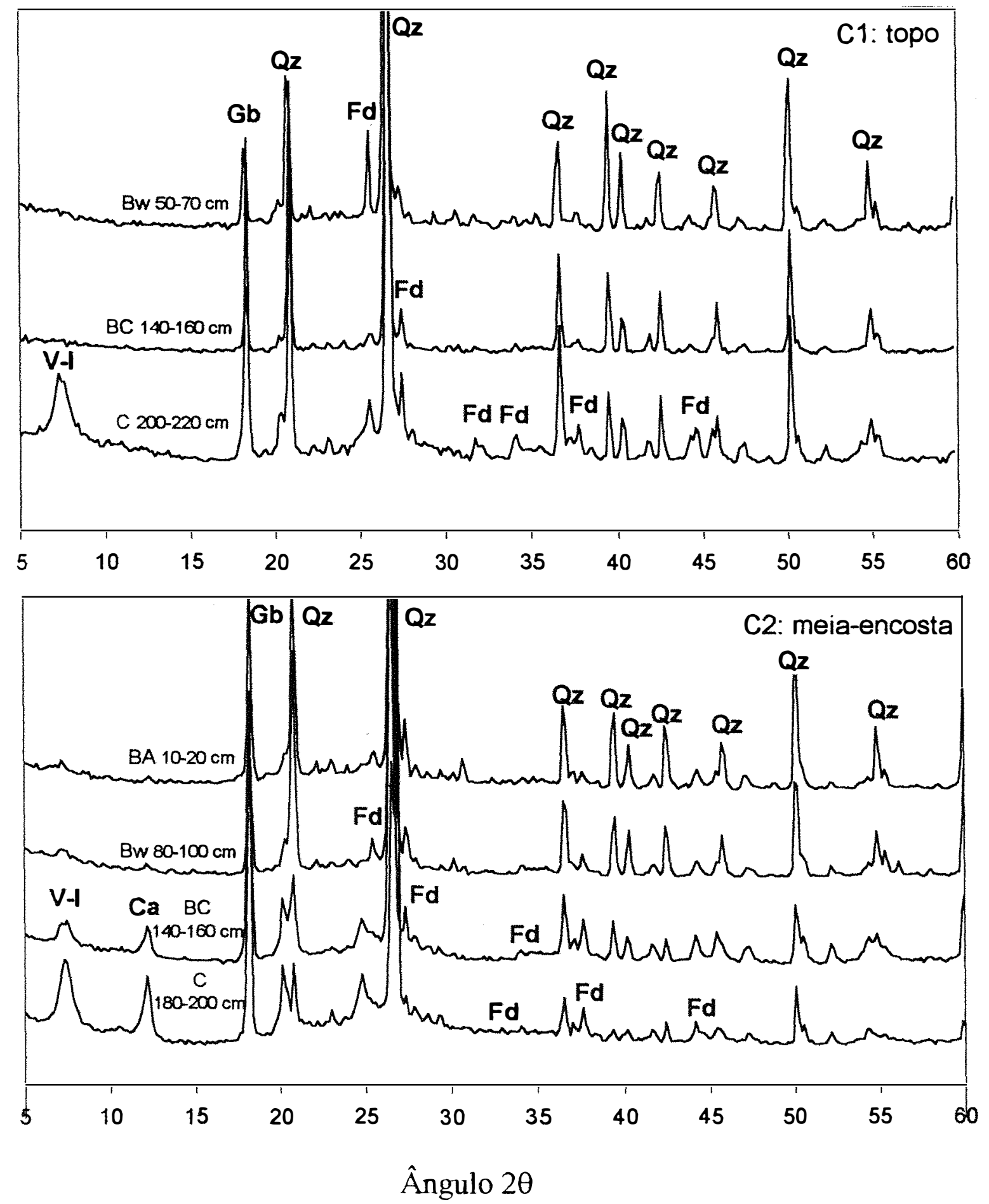

Figura 40 - Difratogramas de raio- $\mathrm{X}$ da fração silte dos perfis na colina: $\mathrm{Ca}=$ caulinita; $\mathrm{Fd}=$ felspatos; $\mathrm{Gb}=$ gibbsita; $\mathrm{Qz}=$ quartzo; V-I=vermiculita-ilita. 

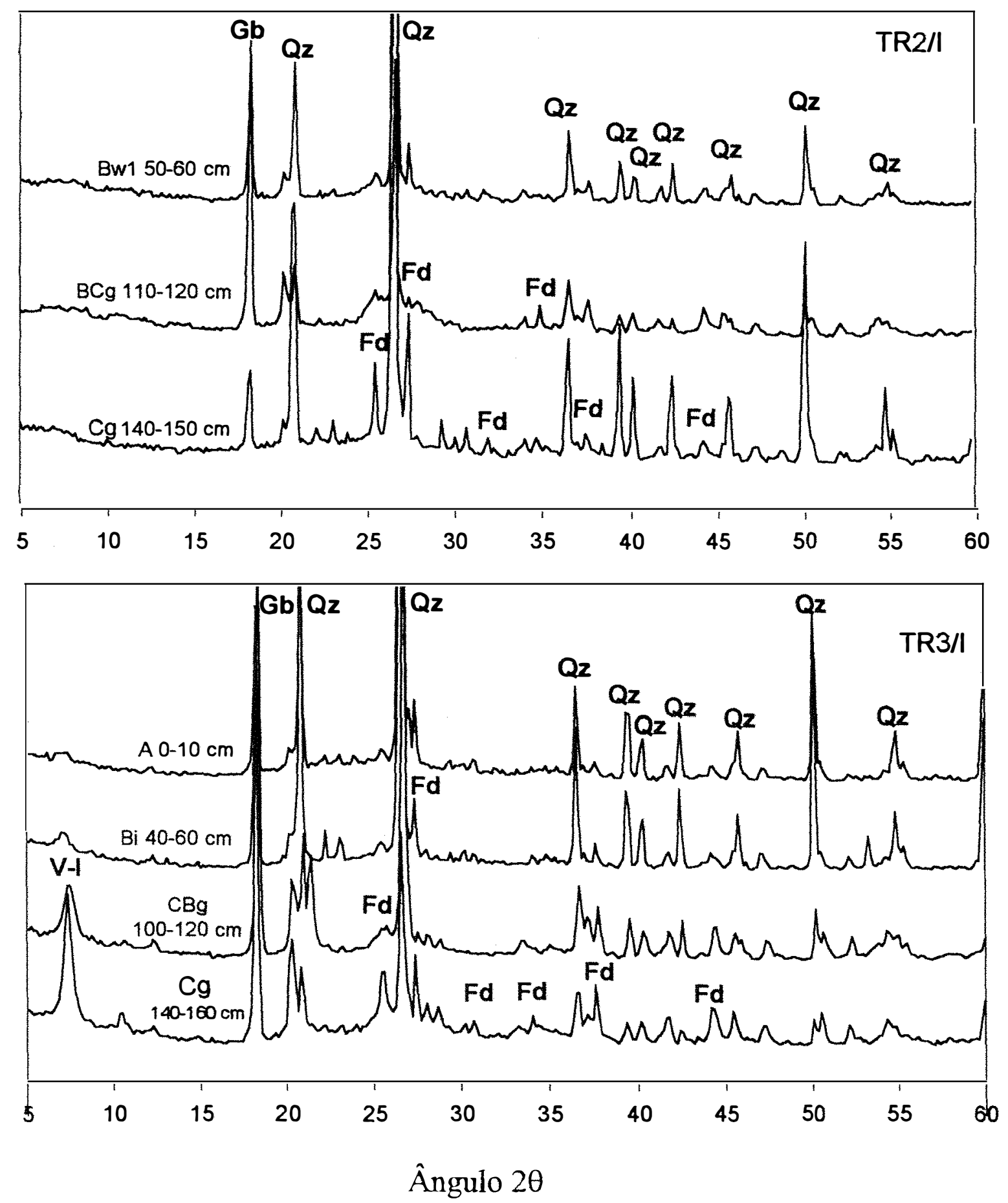

Figura 41 - Difratogramas de raio- $X$ da fração silte dos perfis na borda da colina: $\mathrm{Fd}=$ felspatos; $\mathrm{Gb}=$ gibbsita; $\mathrm{Qz}=$ quartzo; V-I=vermiculita-ilita. 

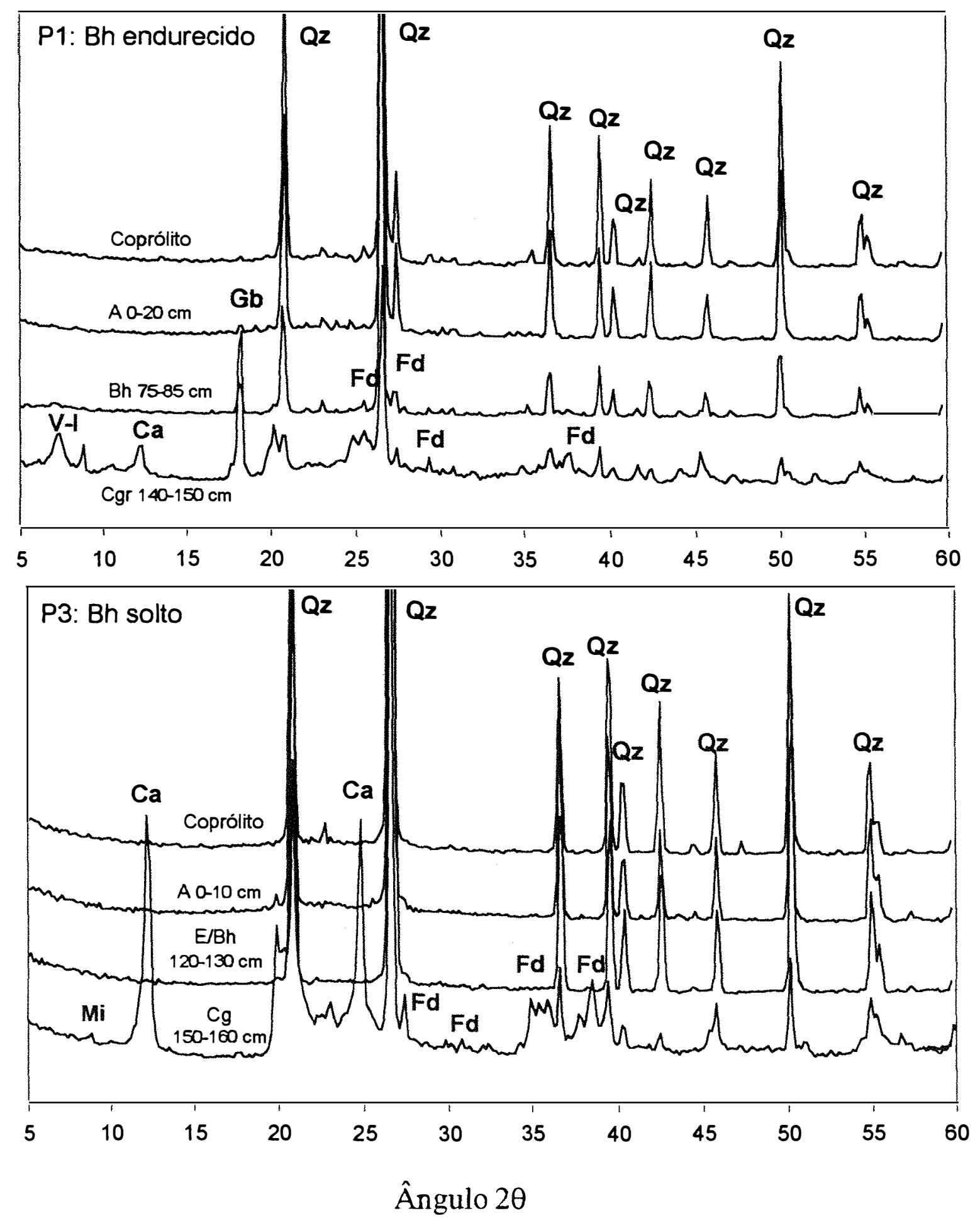

Figura 42 - Difratogramas de raio-X da fração silte dos perfis na planície hidromórfica: $\mathrm{Ca}=$ caulinita; $\mathrm{Fd}=$ =felspatos; $\mathrm{Gb}=$ gibbsita; $\mathrm{Mi}=$ mica; $\mathrm{Qz}=$ quartzo; $\mathrm{V}$ I=vermiculita-ilita. 

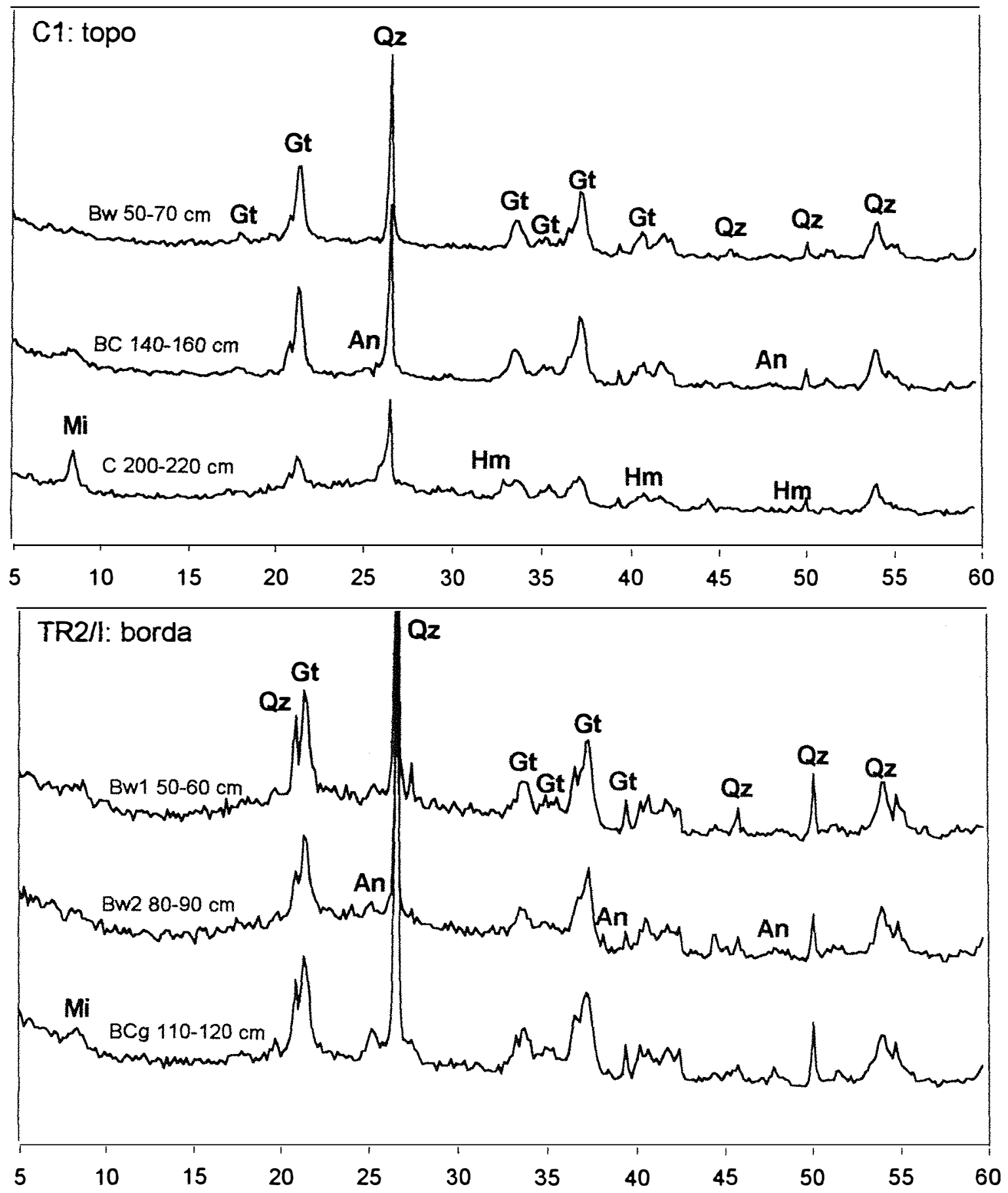

Ângulo $2 \theta$

Figura 43 - Difratogramas de raio $\mathrm{X}$ dos óxidos concentratos dos perfis na colina: $\mathrm{An}=$ anatásio; $\mathrm{Gt}=$ goethita; $\mathrm{Hm}=$ =hematita; $\mathrm{Mi}=$ micas; $\mathrm{Qz}=$ quartzo. 

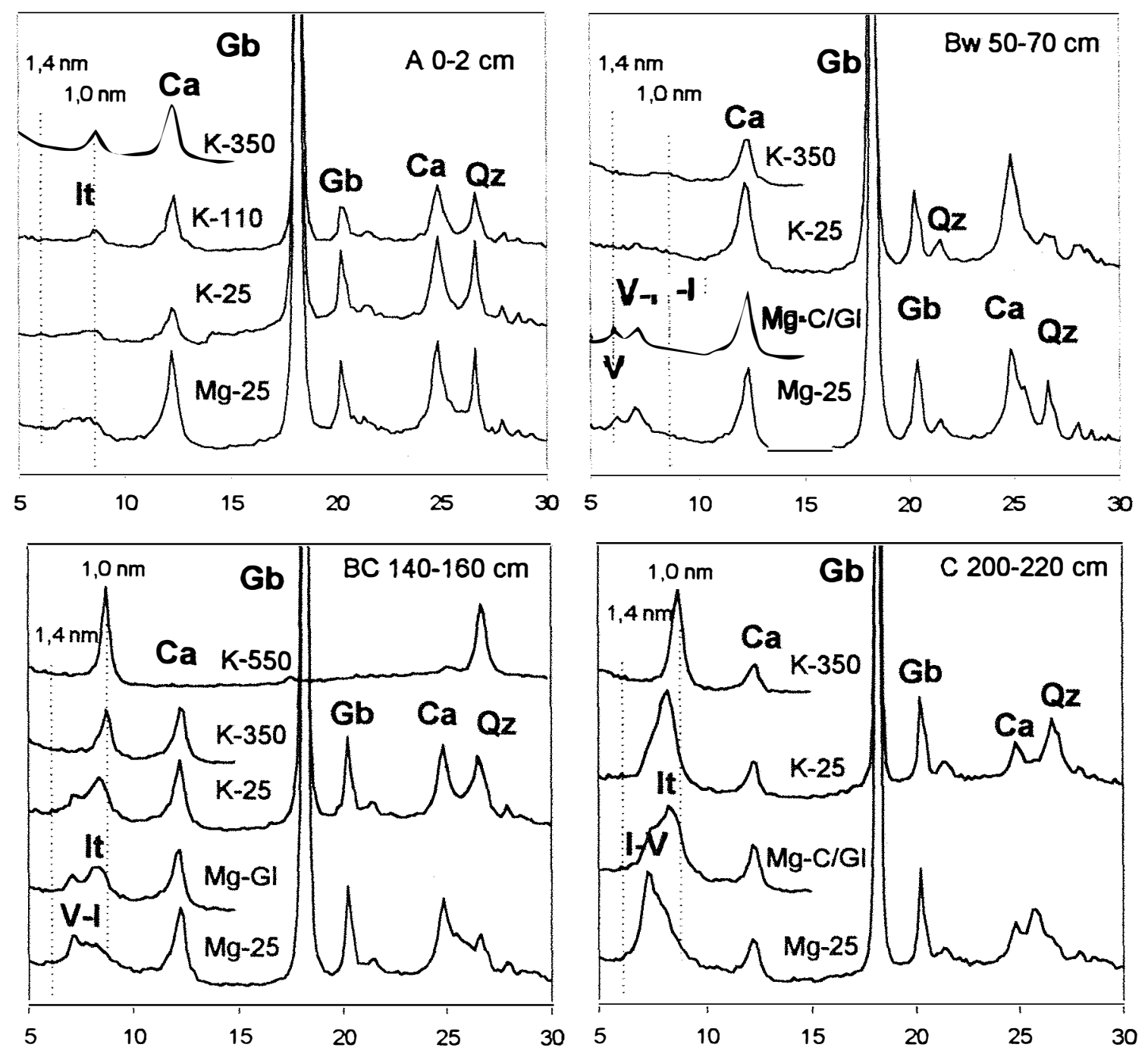

Ângulo $2 \theta$

Ângulo $2 \theta$

Figura 44 - Difratogramas de raio- $X$ da fração argila do perfil $\mathrm{Cl}$, topo da colina: $\mathrm{Ca}=$ caulinita; $\mathrm{Gb}$ =gibbsita; It=ilitas; $\mathrm{I}-\mathrm{V}=$ =ilita-vermiculita; $\mathrm{Qz}=$ quartzo; $\mathrm{V}=$ vermiculita; V-I=vermiculita-ilita. 

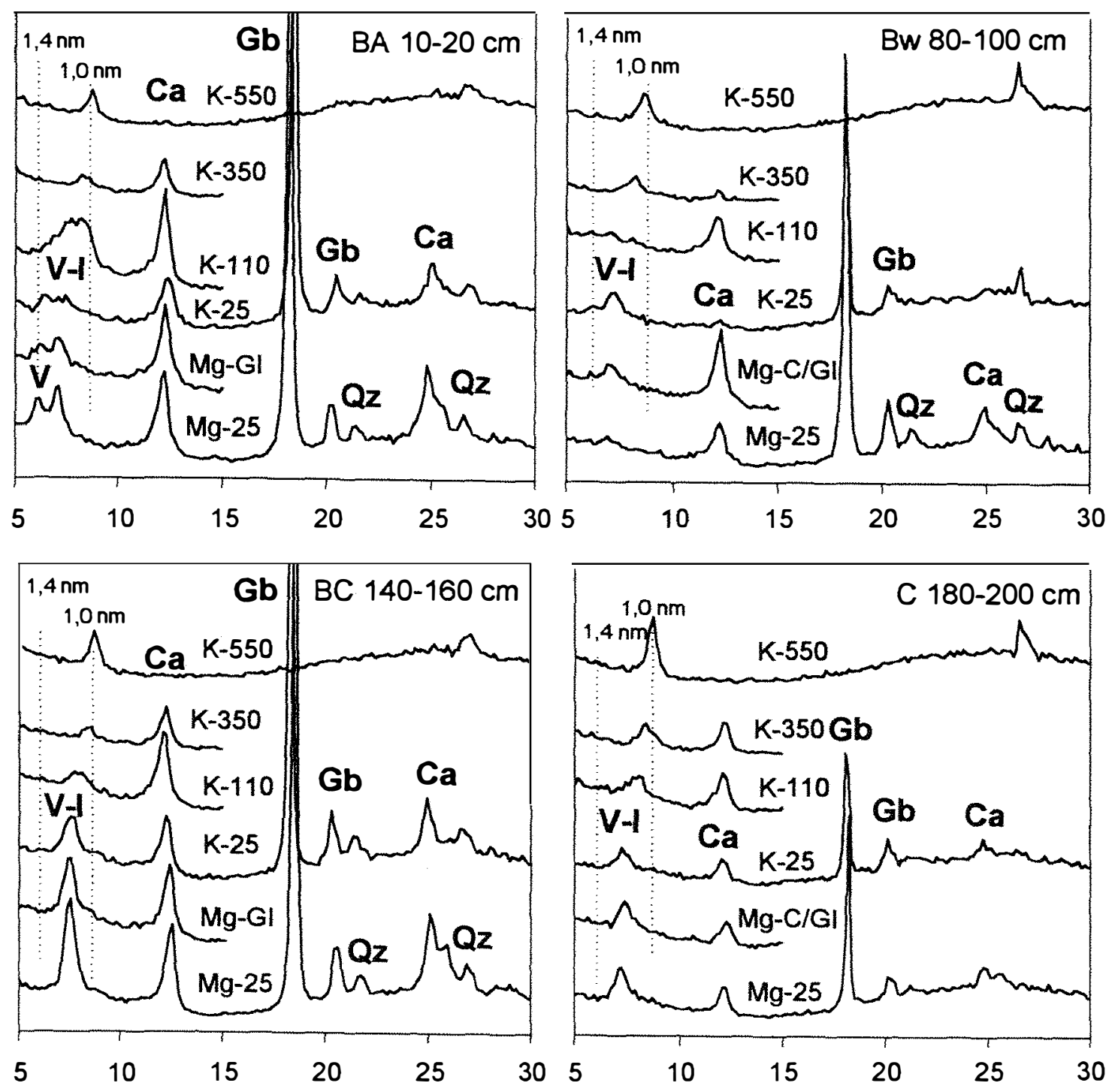

Ângulo $2 \theta$

Ângulo $2 \theta$

Figura 45 - Difratogramas de raio-X da fração argila do perfil C2, meia encosta: $\mathrm{Ca}=$ caulinita; $\mathrm{Gb}=$ gibbsita; $\mathrm{Mi}=$ micas; $\mathrm{Qz}=$ quartzo; $\mathrm{V}=$ vermiculita; V$\mathrm{I}=$ verm.-ilita. 


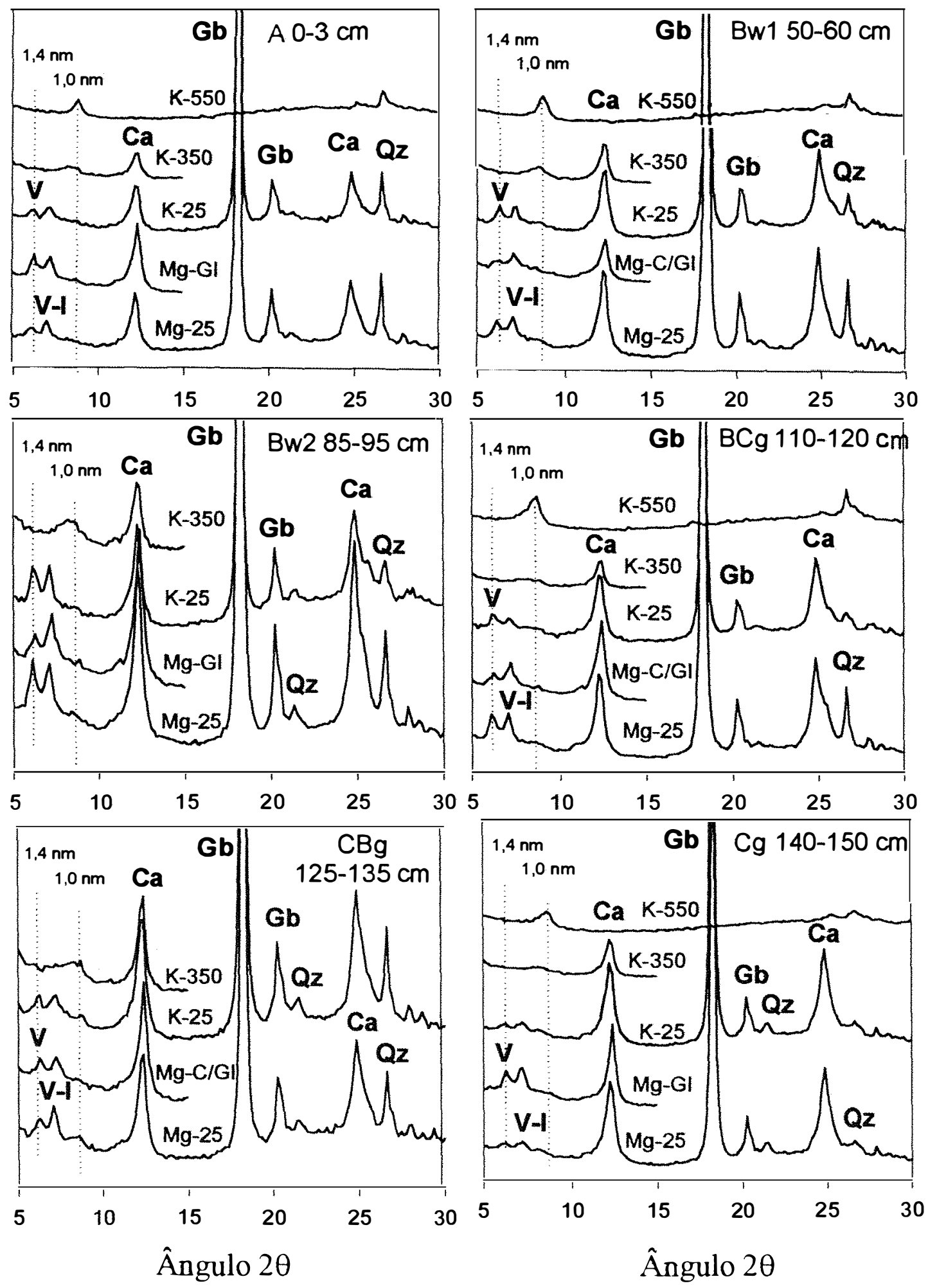

Figura 46 - Difratogramas de raio-X da fração argila do perfil TR2/I, borda da colina: $\mathrm{Ca}=$ caulinita; $\mathrm{Gb}=$ gibbsita; $\mathrm{Q} z=$ quartzo; V=vermiculita; $\mathrm{V}-\mathrm{I}=$ =ermiculita-ilita. 

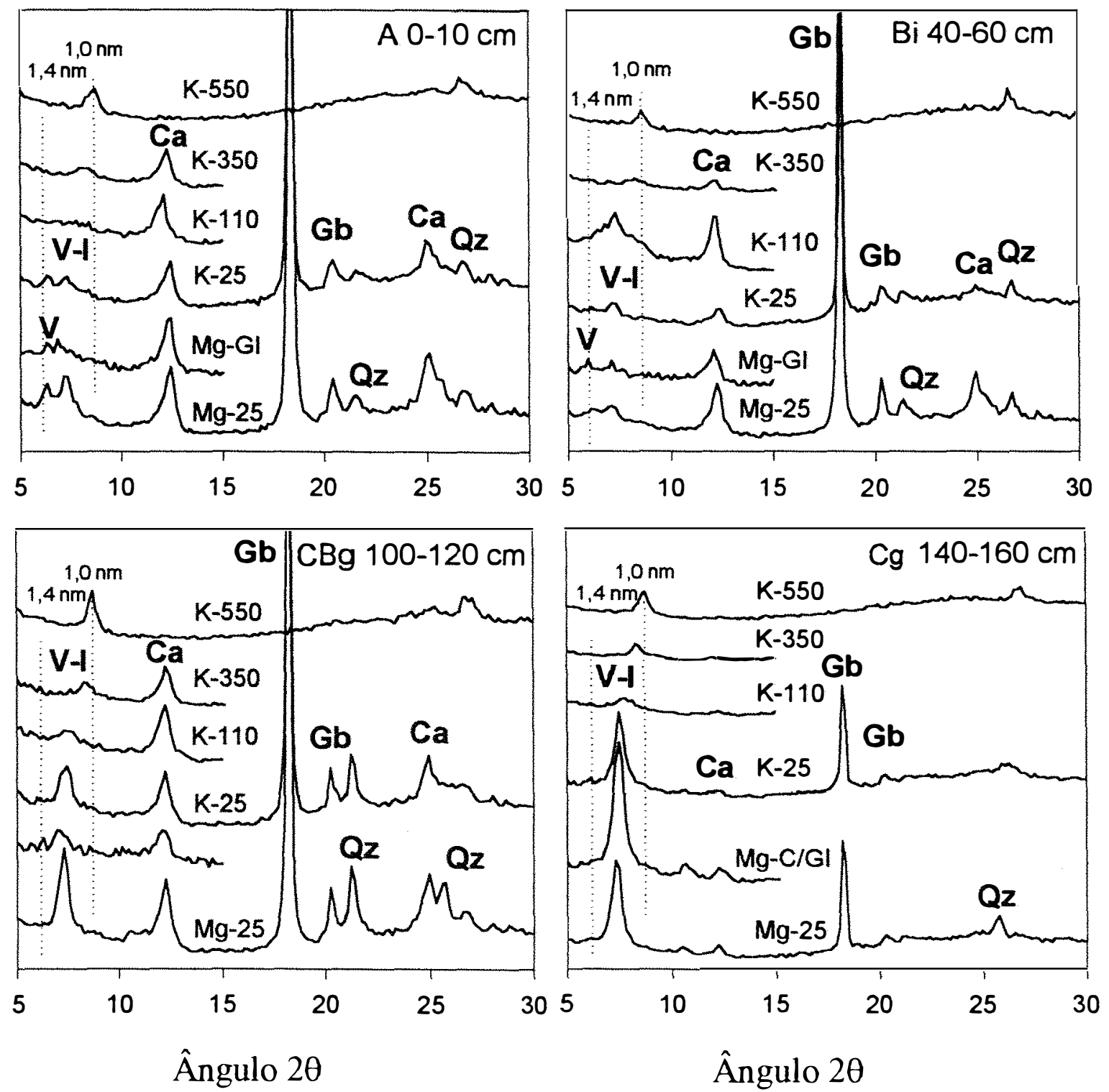

Figura 47 - Difratogramas de raio-X da fração argila do perfil TR3/I, borda da colina: $\mathrm{Ca}=$ caulinita; $\mathrm{Gb}=$ gibbsita; $\mathrm{Q} z=$ quartzo; V=vermiculita; V-I=vermiculita-ilita. 

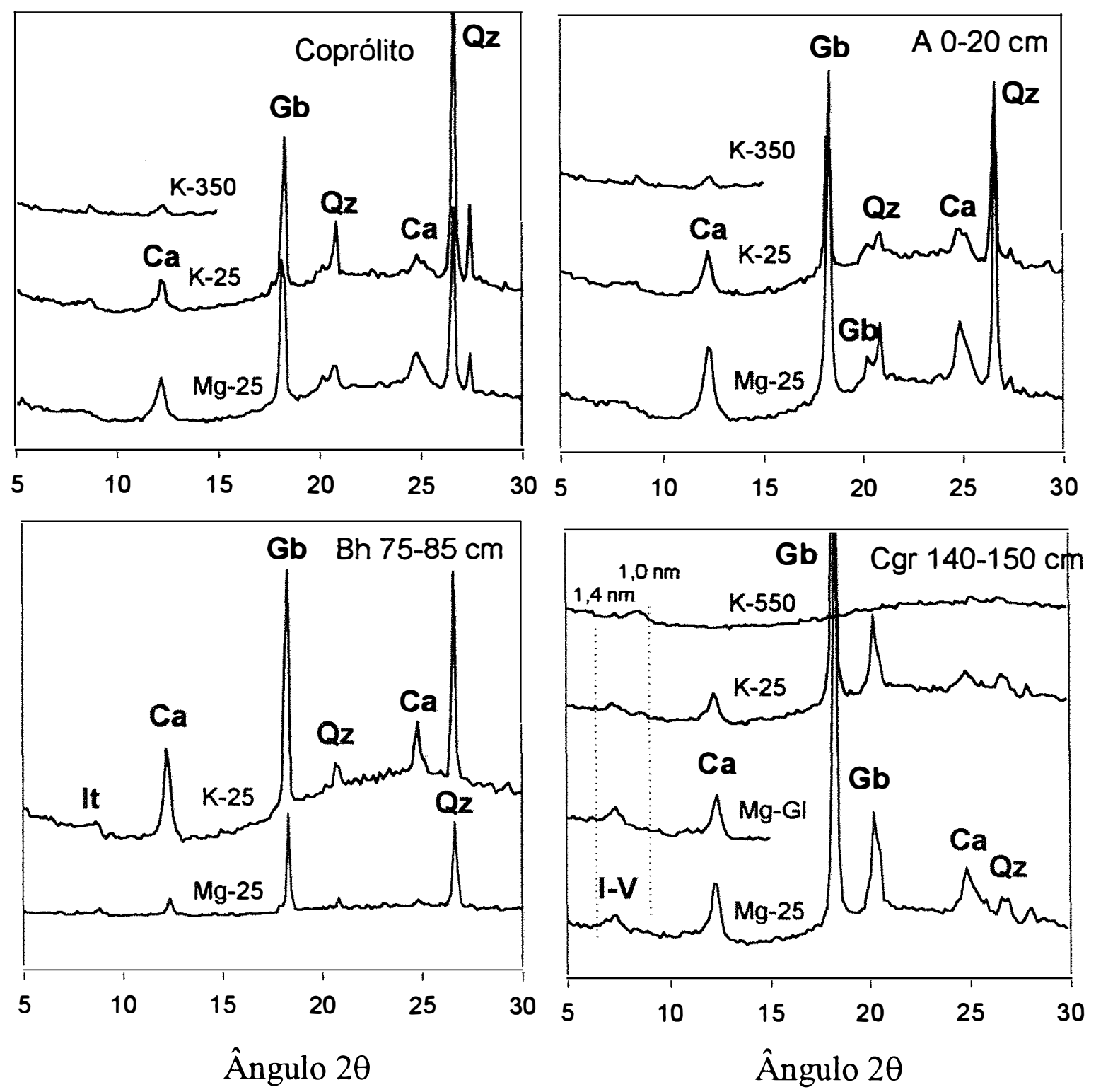

Figura 48 - Difratogramas de raio-X da fração argila do perfil $\mathrm{P} 1$, planície hidromórfica: $\mathrm{Ca}=$ caulinita; $\mathrm{Gb}=$ gibbsita; It=ilitas; $\mathrm{I}-\mathrm{V}=$ =ilita-vermiculita; $\mathrm{Q} z=$ quartzo. 

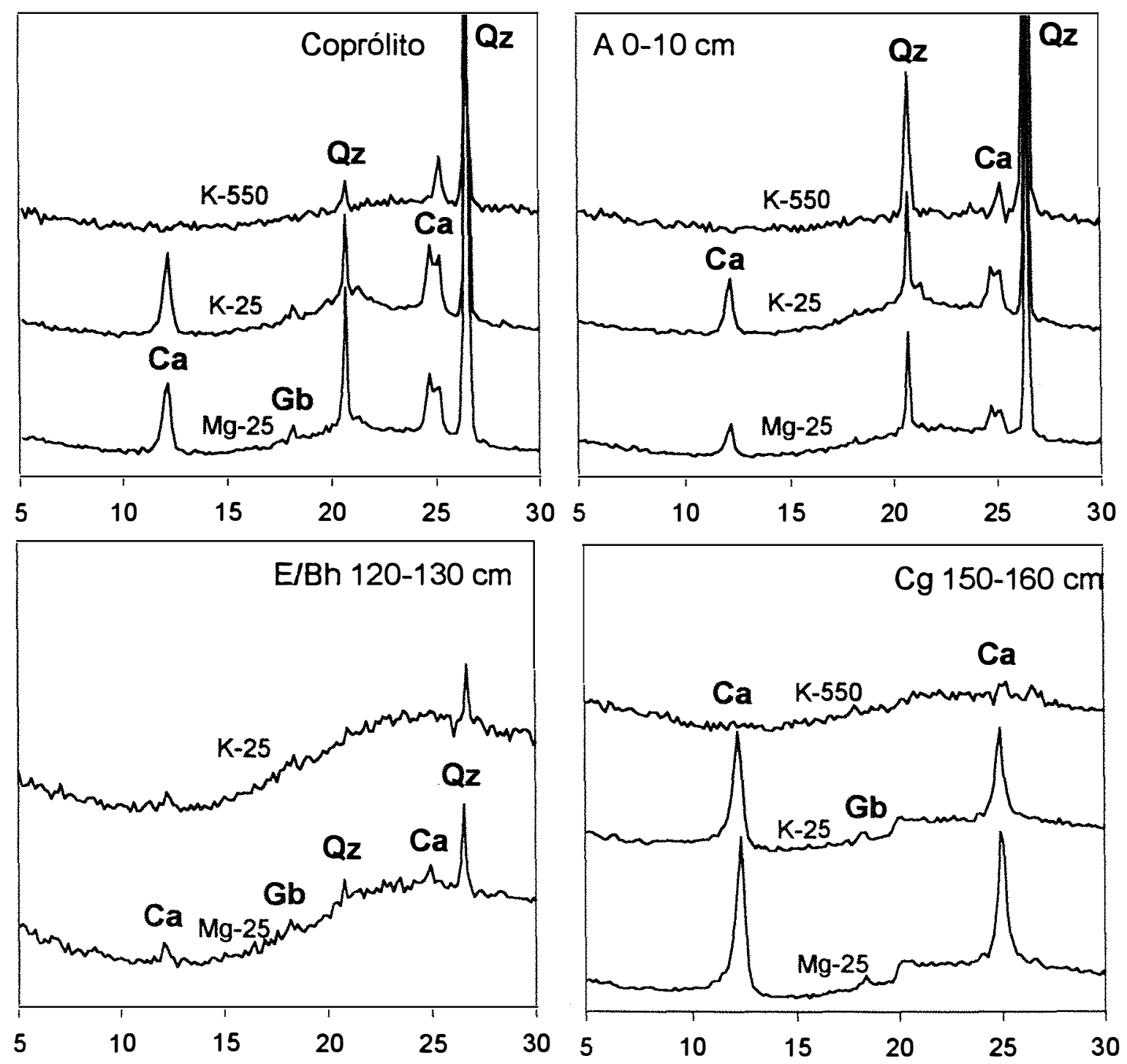

Figura 49 - Difratogramas de raio-X da fração argila do perfil P3, planície hidromórfica: $\mathrm{Ca}=$ caulinita; $\mathrm{Gb}=$ gibbsita; $\mathrm{Q} z=$ quartzo. 


\section{REFERÊNCIAS BIBLIOGRÁFICAS}

ANDRADE, H. Evolução de uma seqüência de solos argilosos até arenosos no Complexo Guianense da Amazônia. Piracicaba, 1990. 179p. Tese (Doutorado) Escola Superior de Agricultura Luiz de Queiroz, Universidade de São Paulo.

ASUMADU, K.; GILKES, R.J.; CHURCHWARD, H.M.; ARMITAGE, T.M. Detailed characterization of quartz grains in two sandy soils, Western Australia. Geoderma, v.41, p.29-47, 1987.

AYRES, I.; GUERRA, R.A.T. Água como fator limitante na distribuição das minhocas (Annelida, Oligochaeta) da Amazônia Central. Acta Amazonica, v.11, p.77-86, 1981.

BARRETT, L.R. Podzolization under forest and stump prairie vegetation in northern Michigan. Geoderma, v.78, p.37-58, 1997.

BONNEAU, M.; SOUCHIER, B. Pédologie II. Constituants et propriétés du sol. Paris: Masson, 1994. 665p.

BOULET, R.; CHAUVEL, A.; HUMBEL, F.X.; LUCAS, Y. Analyse structurale et cartographie en pédologie. Cahiers ORSTOM, Série Pédologie, v.19, p.309-351, 1982.

BOULET, R.; CHAUVEL, A.; LUCAS, Y. Les systémes de transformation en pédologie. In: Livre Jubilaire du Cinquantenaire de Association Française pour l'Étude du Sol. Paris: AFES, 1984. p. 167-179. 
BRABANT, P. La répartition des podzols à Kalimantan (Ile de Bornéo). In: RIGHI, D.; CHAUVEL, A. (Ed.) Podzols et podzolisation. Paris: INRA, 1987. p.13-24.

BRAMMER, H. Pozols in Zambia. Geoderma, v.10, p.249-250, 1973.

BRASIL. Ministério das Minas e Energia. Departamento Nacional da Produção Mineral.

Projeto Radambrasil. Folha NA.19 Pico da Neblina. Rio de Janeiro: MME/DNPM, 1976. 374p. (Levantamento de Recursos Naturais, 11)

BRAVARD, S.; RIGHI, D. Characteristics of clays in an Oxisol-Spodosol toposequence in Amazonia (Brazil). Clay Minerals, v.23, p.279-289, 1988.

BRINKMAN, R. Ferrolysis, a hydromorphic soil forming process. Geoderma, v.3, p.199-206, 1970.

BROWN, G.; BRINDLEY, G.W. X-ray diffraction procedures for clay mineral identification. In: BRINDLEY, G.W.; BROWN, G. Crystal structures of clay minerals and their X-ray identification. London: Mineralogical Society, 1980. p.305-360.

BULLOCK, P.; FEDEROFF, N.; JONGERIUS, A.; STOOPS, G.; TURSINA, T. Handbook for soil thin section description. London: Waine Research Publications, 1985. $152 \mathrm{p}$.

BUOL, S.W.; HOLE, F.D.; McGRACKEN, R.I.; SOUTHARD, R.J. Soil genesis and classification. 4.ed. Ames: The Iowa State University Press, 1997. 527p.

CAMARGO, O.A., MONIZ, A.C., JORGE, J.A., VALADARES, J.M.AS. Métodos de análise química, mineralógica e física de solos. Campinas: IAC, 1986. 94p. (Boletim Técnico, 106)

CASTRO, S.S. Impregnação de amostras de solo para confecção de lâmina delgada. Boletim Informativo da Sociedade Brasileira de Ciência do Solo, v.10, p.44, 1985. 
CERRI, C.C. Alteração e pedogênese em áreas graníticas situadas sob diferentes condições bioclimáticas encontradas no Brasil. São Paulo, 1979. 241p. Tese (Doutorado) - Instituto de Geociências, Universidade de São Paulo.

CHAUVEL, A.; LUCAS, Y.; BOULET, R. On the genesis of the soil mantle of the region of Manaus, Central Amazonia, Brazil. Experientia, v.43, p.234-241, 1987.

COLINVAUX, P.A.; OLIVEIRA, P.E.; MORENO, J.E.; MILLER, M.C.; BUSH, M.B. A long pollen record from lowland Amazonia: Forest and cooling in glacial times. Science, v.174, p.85-88, 1996.

COSTA, J.B.S.; BERMEGUY, R.L; HASUI, Y.; BORGES, M.S.; FERREIRA JÚNIOR, C.R.P.; BEZERRA, P.E.L.; COSTA, M.L.; FERNANDES, J.M.G. Neotectônica da região amazônica: aspectos tectônicos, geomorfológicos e deposicionais. Geonomus, v.4, p.23-44, 1996.

DE CONINCK, F. Major mechanisms in formation of spodic horizons. Geoderma, v.24, p.101-128, 1980.

DE CONINCK, F.; RIGHI, D. Podzolisation and the spodic horizon. In: BULLOCK, P.; MURPHY, C.P. Soil micromorphology: soil genesis. Berkhamsted: AB Academic Publishers, 1983. v.2, p.389-417.

DEMATTE, J.A.M.; ALOISI, R.R.; DEMATTE, J.L.I. Seqüência Latossolo Amarelo Podzólico Amarelo - Areias Quartzosas sob material da Formação Barreiras na região de Tucuruí, Estado do Pará. Scientia Agricola, v.51, p.345-356, 1994.

DUBROEUCQ, D.; BLANCANEAUX, P. Les podzols du haut rio Negro, region de Marao, Venezuela. Environnement et relations lihologiques. In: RIGHI, D.; CHAUVEL, A. (Ed.) Podzols et podzolisation. Paris: INRA, 1987. p.37-52.

DUBROEUCQ, D.; VOLKOFF, B. Evolution des couvertures pedologiques sableuses a podzols geants d'Amazonie (Bassin du Haut rio Negro). Cahiers ORSTOM, Série Pédologie, v.24, p.191-214, 1988. 
DUBROEUCQ, D.; VOLKOFF, B. From Oxisols to Spodosols and Histosols: evolution of the soil mantles in the Rio Negro basin (Amazonia). Catena, v.32, p.245-280, 1998.

DUBROEUCQ, D.; VOLKOFF, B.; FAURE, P. Les couvertures pédologiques à Podzols du Bassin du Haut Rio Negro (Amazonie). Étude et Gestion des Sols, v.6, p.131-153, 1999.

DUBROEUCQ, D.; VOLKOFF, B.; PEDRO, G. La couverture pédologique du bouclier du nord de l'Amazonie (bassin du Haut Rio Negro). Séquence évolutive des sols et son rôle dans l'aplanissement généralisé des zones tropicales perhumides. Comptes Rendus de l'Academie de Sciences, Paris, Série II, t.312, p.663-671, 1991.

DUCHAUfOUR, P.; SOUCHIER, B. Pédologie I. Pédogènese et classification. Paris: Masson, 1983. 491p.

EMPRESA BRASILEIRA DE PESQUISA AGROPECUÁRIA. Centro Nacional de Pesquisa de Solos. Manual de métodos de análise de solo. 2.ed. Rio de Janeiro: EMBRAPA, 1997. 212p. (EMBRAPA/CNPS. Documentos, 1)

EMPRESA BRASILEIRA DE PESQUISA AGROPECUÁRIA. Centro Nacional de Pesquisa de Solos. Sistema brasileiro de classificação de solos. Brasília: EMBRAPA, Produção de Informação; Rio de Janeiro: EMBRAPA, Centro Nacional de Pesquisa de Solos, 1999. 412p.

EMPRESA BRASILEIRA DE PESQUISA AGROPECUÁRIA. Serviço Nacional de Levantamento e Conservação de Solos. Mapa de Solos do Brasil. Rio de Janeiro: EMBRAPA/SNLCS, 1981.

ESCHENBRENNER, V. Contribution des termites à la microagregation des sols tropicaux. Cahiers ORSTOM, Série Pédologie, v.22, p.387-408, 1986.

ESTADOS UNIDOS. Department of Agriculture. Natural Resources Conservation Service. Soil Survey Staff. Keys to soil taxonomy. 8.ed. Washington: USDA, 1998. 326p. 
ESWARAN, H.; BIN, W.C. A study of a deep weathering profile on granite in peninsular Malaysia: I. Physico-chemical and micromorphological properties. Soil Science Society of America Journal, v.42, p. 144-149, 1978a.

ESWARAN, H.; BIN, W.C. A study of a deep weathering profile on granite in peninsular Malaysia: II. Mineralogy of the clay, silt and sand fractions. Soil Science Society of America Journal, v.42, p.149-153, 1978 b.

ESWARAN, H.; BIN, W.C. A study of a deep weathering profile on granite in peninsular Malaysia: alteration of feldspars. Soil Science Society of America Journal, v.42, p.154-158, 1978c.

ESWARAN, H.; STOOPS, G. Surface textures of quartz in tropical soils. Soil Science Society of America Journal, v.43, p.420-424, 1979.

FALESI, I.C. O estado atual dos conhecimentos sobre os solos da Amazônia brasileira. In: SIMPÓSIO DO TRÓPICO ÚMIDO, 1., Belém, 1986. Anais. Belém: IPEAN, 1986. p.17-61. (Boletim Técnico, 45)

FARMER, V.C.; RUSSELL, J.D.; BERROW, M.L. Imogolite and proto-imogolite allophane in spodic horizons: Evidence for a mobile aluminium silicate complex in podzol formation. Journal of Soil Science, v.31, p.673-684, 1980.

FARMER, V.C.; SKJEMSTAD, J.O.; THOMPSON, C.H. Genesis of humus B horizons in hydromorphic humus podzols. Nature, v.304, p.342-344, 1983.

FOLK, R.L.; WARD, W.C. Brazos river bar: a study on the significance of grain-size parameters. Journal of Sedimentary Petrology, v.27, p.3-26, 1957.

FORTI, M.C.; MELFI, A.J.; AMORIM, P.R.N. Hidroquímica das águas de drenagem de uma pequena bacia hidrográfica no Nordeste da Amazônia (Estado do Amapá, Brasil): Efeitos da sazonalidade. Geochimica Brasiliensis, v.11, p.325-340, 1997.

FRANCO, E.M.S.; DEL'ARCO, J.O.; RIVETTI, M. Geomorfologia. In: BRASI. Ministério das Minas e Energia. Departamento Nacional da Produção Mineral. Projeto Radambrasil, Folha NA.20 Boa Vista e parte das folhas NA.21 
Tumucumaque e NB.20 Roraima. Rio de Janeiro: MME/DNPM, 1975. p.137-180 (Levantamento dos Recursos Naturais, 8)

FRANCO, W.; DEZZEO, N. Soils and soil water regime in the terra firme-caatinga forest complex near San Carlos de Rio Negro, State of Amazonas, Venezuela. Interciencia, v.19, p.305-316, 1994.

FRITSCH, E. Morphologie des quartz d'une couverture ferrallitique degradée par hydromorphie. Cahiers ORSTOM, Série Pédologie, v.24, p.3-15,1988.

GAVAUD, M.; BlanCANEAUX, P.; DUBROEUCQ, D.; POUYLlaU, M. Les paysages pédologiques de l'Amazonie venezuelienne. Cahiers ORSTOM. Série Pédologie, v.22, p.265-284, 1986.

GOMES, J.B.V.; RESENDE, M.; REZENDE, S.B.; MENDONÇA, E.S. Areias do litoral fluminense. Ciência Hoje, v.23, n.137, p.44-50, 1998.

GRIMALDI, C.; PEDRO, G. Importance de l'hydrolyse acide dans les systèmes pédologiques des régions tropicales humides. Comptes Rendus de l'Académie des Sciences, Paris, Série IIa, t.323, p.483-492, 1996.

GRZEBYK, M.; DUBROEUCQ, D. Quantitative analysis of distribution of soil types: existence of an evolutionary sequence in Amazonia. Geoderma, v.62, p.285-298, 1994.

JAKOBSEN, B.H. Multiple processes in the formation of subarctic podzols in Greenland. Soil Science, v.152, p.414-426, 1991.

JAMET, R.; GUILLET, B.; ROBERT, M.; RANGER, J.; VENEAU, G. Study of current dynamics of soils from a Podzol-Oxisol sequence in Tahiti (French Polynesia) using the test-mineral technique. Geoderma, v.73, p.107-124, 1996.

JEANROY, E.; RAJOT, J.L.; PILLON, P.; HERBILLON, A.J. Differential dissolution of hematite and goethite in dithionite and its implication on soil yellowing. Geoderma, v.50, p.79-94, 1991. 
KITAGAWA, Y.; MOLLER, R.F. Clay mineralogy of some typical soils in the brazilian amazon region. Pesquisa Agropecuária Brasileira, v.14, p.201-228, 1979.

KLINGE, H. Podzol soils in the amazon basin. Journal of Soil Science, v.16, p.95-103, 1965.

KLINGE, H. Podzol soils: a source of blackwater rivers in Amazonia. In: LENT, H. Atas do simpósio sobre a biota amazônica. Rio de Janeiro: Concelho Nacional de Pesquisas. 1967. v.2, p.117-125. (Limnologia)

KRUMBEIN, W.C.; SLOSS, L.L. Stratigraphy and sedimentation. 2.ed. San Francisco: W.H. Freeman and Company. 1963.660p.

LEMOS, R.C.; SANTOS, R.D. Manual de método de trabalho de campo. 3.ed. Campinas: Sociedade Brasileira de Ciência do Solo, 1996. 83p.

LESACK, L.F.W.; MELACK, J.M. Mass balance of major solutes in a rainforest catchment in the Central Amazon: Implications for nutrient budgets in tropical rainforest. Biogeochemistry, v.32, p.115-142, 1996.

LIMA, A.A.C. Características de Latossolos Amarelos da Amazônia brasileira, Piracicaba, 1980. 142p. Dissertação (Mestrado) - Escola Superior de Agricultura "Luiz de Queiroz", Universidade de São Paulo.

LIMA, P.C.; CURI, N.; LEPSCH, I.F. Terminologia de micromorfologia do solo. Boletim Informativo da Sociedade Brasileira de Ciência do Solo, v.10, p.33-43, 1985.

LISBOA, P.L. Estudos sobre a vegetação das Campinas Amazônicas - II. Observações gerais e revisão bibliográfica sobre as campinas amazônicas de areia branca. Acta Amazonica, v.5, p.211-223, 1975.

LUCAS, Y. Systèmes pédologiques en Amazonie brésilienne. Equilibres, déséquilibres et transformations. Paris, 1989. 157p. Thèse (Doctorat) - Universite Poitiers. 
LUCAS, Y. The bauxite of Juriti. In: CARVALHO, A.; BOULANGÉ, B.; MELFI, A.J. (Ed.) Brazilian bauxites. São Paulo: USP/FAPESP, Paris: ORSTOM, 1997. p.107-136.

LUCAS, Y.; BOULET, R.; CHAUVEL, A. Intervention simultanée des phénomènes d'enfoncement vertical et de transformation latérale dans la mise en place des systèmes de sols de la zone tropicale humide. Cas des systèmes de sols ferralitiquespodzols de l'Amazonie Brésilienne. Comptes Rendus de l'Academie des Sciences, Paris, Série 2, t.306, p.1395-1400, 1988.

LUCAS Y., CHAUVEL A., BOULET R., RANZANI G., SCATOLINI F. Transição latossolos-podzóis sobre a formação Barreiras na região de Manaus, Amazônia. Revista Brasileira de Ciência do Solo, v.8, p.325-335, 1984.

LUCAS, Y.; NAHON, D.; CORNU, S.; EYROLLE, F. Genèse et fonctionnement des sols en milieu équatorial. Compte Rendus de l'Academie de Sciences, Paris, Série IIa, t.322, p.1-16, 1996.

MACIAS, F.; CHESWORTH, W. Weathering in humid regions, with emphasis on igneous rocks and their metamorphic equivalents. In: MARTINI, I.P.; CHESWORTH, W. Weathering, soils and paleosols. Amsterdam: Elsevier, 1992. p.283-306. (Developments in Earth Surface Processes, 2)

McKEAGUE, J.A.; CHESHIRE, M.V.; ANDREUX, F.; BERTHELIN, J. Organomineral complexes in relation to pedogenesis. In: HUANG, P.M.; SCHNITZER, M. (Ed.) Interactions of soil minerals with natural organics and microbes. Madison: SSSA, 1986. p.549-592. (Special Publication, 17)

MELFI, A.J.; FRITSCH, E.; BOULET, R.; SEYLER, F.; CARVALHO, A.; MAGAT, P. Distribuição dos solos nas paisagens lateriticas da amazônia: elaboração de um modelo conceitual ilustrando a evolução hidrobiogeoquimica destas paisagens (compact disc). In: CONGRESSO LATINO-AMERICANO DE CIÊNCIA DO SOLO, 13., Águas de Lindóia, 1996. Solo-suelo 96: trabalhos. Piracicaba: SBCS/SLCS, 1996. 
MELFI, A.J.; PEDRO, G. Estudo geoquímico dos solos e formações superficiais do Brasil. 1. Caracterização e repartição dos principais tipos de evolução pedogeoquímica. Revista Brasileira de Geociências, v.7, p.271-286, 1977.

MELFI, A.J.; PEDRO, G. Considerações sobre os mecanismos geoquímicos envolvidos na alteração superficial e sua repartição no Brasil. Revista Brasileira de Geociências, v.8, p.11-22, 1978.

MIKLÓS, A.A.W. Biodynamique d'une couverture pedologique dans la region de Botucatu, Brésil. Paris, 1992. v. 1 e v2. Thèse (Doctorat) - Université Paris VI.

MOORE, D.M.; REYNOLDS JR., R.C. X-ray diffraction and the identification and analysis of clay minerals. New York: Oxford University Press, 1989. 332p.

RESENDE, M.; CURI, N.; REZENDE, S.B.; CORRÊA, G.F. Pedologia: base para distinção de ambientes. Viçosa: NEPUT, 1995. 304p.

RIBEIRO, L.P. Os Latossolos Amarelos do Recôncavo Bahiano: gênese, evolução e degradação. Salvador: Seplantec, CADCT, 1998. 99p.

RIGHI, D.; BRAVARD, S.; CHAUVEL, A.; RANGER, J.; ROBERT, M. In situ study of soil processes in an oxisol-spodosol sequence of Amazonia (Brazil). Soil Science, v. 150, p. $438-445 ; 1990$.

ROBERT, M.; RAZZAGHE, M.H.; RANGER, J. Role du facteur biochimique dans la podzolisation. Etudes experimentales sur les mecanismes geochimiques et les evolutions mineralogiques. In: RIGHI, D.; CHAUVEL, A. (Ed.) Podzols et podzolisation. Paris: INRA, 1987. p.207-233.

RODRIGUES, W.A. Aspectos fitossociológicos das caatingas do Rio Negro. Boletim do Museu Paraense Emílio Goeldi, Série Botânica, n. 15, p. 1-62, 1961.

SCHWARTZ, D. Les podzols tropicaux sur sables Bateke en R.P. du Congo. Description, caracterisation, genese. In: RIGHI, D.; CHAUVEL, A. (Ed.) Podzols et podzolisation. Paris: INRA, 1987. p.25-36. 
SCHWERTMANN, U.; TAYLOR, R.M. Iron oxides. In: DIXON, J.B.; WEED, S.B. (Ed.) Minerals in soil environments. Madison: SSSA, 1989. p.379-438.

SEGALEN, P. Les sols ferrallitiques et leur repartition geographique. Tome 2: les sols ferrallitiques: les facteurs de formation et les sols ferrallitiques en Amerique. Paris: ORSTOM, 1994. 169p.

SIOLI, H. Hydrochemistry and geology in the Brazilian Amazon Region. Amazoniana, v.1, p.267-277, 1968.

SIOLI, H. Tropical rivers as expressions of their terrestrial environments. In: GOLLEY, F.B.; MEDINA, E. Tropical ecological systems: Trends in terrestrial and aquatic research. Berlin: Springer-Verlag, 1975. p. 275-288.

SOMBROEK, W.G. Soil of the Amazon region. In: The Amazon: Limnology and landscape ecology of a mighty tropical river and its basin. Dordrecht: W. Junk Publication, 1984. p.522-535.

STOOPS, G.; BUOL, S.W. Micromorphology of oxisols. In: DOUGLAS, L.A.; THOMPSON, M.L. (Ed.) Soil micromorphology and classification. Madison: SSSA, 1985. p.105-119. (SSSA Publication, 15)

SUGUIO, K. Introdução à sedimentologia. São Paulo: Edgar Blucher/EDUSP, 1973. $317 \mathrm{p}$.

TAMURA, T. Identification of the $14 \AA$ clay mineral component. American Mineralogist, v.42, p.107-110, 1957.

TARDY, Y. Pétrologie des latérites et des sols tropicaux. Paris: Masson, 1993. 459p.

TARDY, Y.; ROQUIN, C. Geochemistry and evolution of lateritic landscapes. In: MARTINI, I.P.; CHESWORTH, W. Weathering, soils and paleosols. Amsterdam: Elsevier, 1992. p.407-443. (Developments in Earth Surface Processes, 2)

THOMAS, M; THORP, M.; McALISTER, J. Equatorial weathering, landform development and formation of white sands in north western Kalimantan, Indonesia. Catena, v.36, p.205-232, 1999. 
THOREZ, J. Practical identification of clay minerals. Dison: G. Lelotte, 1976. 90p.

UNIVERSIDADE DE BRASÍLIA, Instituto de Geociências. Hidrologia e geoquímica da bacia amazônica. http://www.unb.br/ig/hibam/campanhas, 29/12/1999.

VAN LIER, Q.J.; VIDAL-TORRADO, P. Phi: programa de microcomputador para análise estatística da granulometria de sedimentos. Revista Brasileira de Ciência do Solo, v. 16, p.277-281, 1992.

VAN WAMBEKE, A.R. Criteria for classifying tropical soils by age. Journal of Soil Science, v.13, p.124-132, 1962.

VILLA NOVA, N.A.; SALATI, E.; MATSUI, E. Estimativa de evapotranspiração na Bacia Amazônica. Acta Amazonica, v.6, p.215-228, 1976.

VOLKOFF, B. Organizations régionales de la couverture pédologique du Brésil. Chronologie des différenciations. Cahiers ORSTOM, Serie Pedologie, v.21, p.225-236, 1985.

WEISS, J. Handbook of ion cromatography. Sunnyvale: Dionex Corporation, 1986. $244 \mathrm{p}$. 